University of Louisville

ThinkIR: The University of Louisville's Institutional Repository

Electronic Theses and Dissertations

$12-2010$

\title{
Messianic light : utopian discourse in the work of Theodor W. Adorno, Luce Irigaray and Giorgio Agamben.
}

Heather Anne Thiessen 1956-

University of Louisville

Follow this and additional works at: https://ir.library.louisville.edu/etd

\section{Recommended Citation}

Thiessen, Heather Anne 1956-, "Messianic light : utopian discourse in the work of Theodor W. Adorno, Luce Irigaray and Giorgio Agamben." (2010). Electronic Theses and Dissertations. Paper 1427. https://doi.org/10.18297/etd/1427

This Doctoral Dissertation is brought to you for free and open access by ThinkIR: The University of Louisville's Institutional Repository. It has been accepted for inclusion in Electronic Theses and Dissertations by an authorized administrator of ThinkIR: The University of Louisville's Institutional Repository. This title appears here courtesy of the author, who has retained all other copyrights. For more information, please contact thinkir@louisville.edu. 
MESSIANIC LIGHT: UTOPIAN DISCOURSE IN THE WORK OF

THEODOR W. ADORNO, LUCE IRIGARAY AND GIORGIO AGAMBEN

By

Heather Anne Thiessen

B.A., Michigan State University, 1981

M.A., University of Chicago, 1982

M.Div., Louisville Presbyterian Theological Seminary, 2000

Th.M., Louisville Presbyterian Theological Seminary, 2002

\author{
A Dissertation \\ Submitted to the Faculty of the \\ Graduate School of the University of Louisville \\ in Partial Fulfillment of the Requirements \\ for the Degree of
}

Doctor of Philosophy

\footnotetext{
Division of Humanities

University of Louisville

Louisville, Kentucky
}

December 2010 
This work is licensed under the Creative Commons Attribution 3.0 Unported License. To view a copy of this license, visit http://creativecommons.org/licenses/by/3.0/ or send a letter to Creative Commons, 171 Second Street, Suite 300, San Francisco, California, 94105, USA. 


\begin{abstract}
MESSIANIC LIGHT: UTOPIAN DISCOURSE IN THE WORK OF
THEODOR W. ADORNO, LUCE IRIGARAY AND GIORGIO AGAMBEN
\end{abstract}

By

Heather Anne Thiessen

B.A., Michigan State University, 1981

M.A., University of Chicago, 1982

M.Div., Louisville Presbyterian Theological Seminary, 2000

Th.M., Louisville Presbyterian Theological Seminary, 2002

A Dissertation Approved on

October 25,2010

by the following Dissertation Committee:

Dhssertation Director 


\author{
DEDICATION \\ To the remarkable women who \\ taught me to read the Bible. \\ פי לא לנצח ישכח אביון

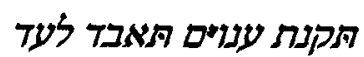 \\ "Eor the needy will not always be forgotten, \\ nor the hope of the poor perish forever." \\ Ps. $9: 18$
}


ACKNOWLEDGMENTS

I thank all the members of the committee, Dr. Annette Allen, Dr. Steven Matthew Biberman, Dr. Carl Hausman, and Dr. David Owen, for their patience over many years. A special debt of thanks for guidance and calm persistence goes to Dr. Mary Ann Stenger. Thanks to the Women's Center at Louisville Presbyterian Theological Seminary for a leave that made this work possible, and for the possibilities that made taking it a struggle. Finally, deep thanks to my family, and in particular to Zoe, whose gift of parrhēsia is beyond price. 
ABSTRACT

MESSIANIC LIGHT: UTOPIAN DISCOURSE IN THE WORK OF THEODOR W. ADORNO, LUCE IRIGARAY AND GIORGIO AGAMBEN

Heather A. Thiessen

December 15, 2010

What is the idea that "utopia" names? How can discourse represent that idea? Setting aside temporarily deeper problems with the idea of representation, and focusing on how a complex philosophical discourse might approach the problem of conveying or representing a large, only fairly precise, and important idea is the question of this dissertation. It ultimately answers that question obliquely, by focusing on the way the utopian discourse present in the work of three late $20^{\text {th }}$ century philosophers, Theodor W. Adorno, Luce Irigaray, and Giorgio Agamben, addresses a subject position that can be named a "subject of possibility." How this subject of possibility might relate to the possibilities for transcendence located in the material world that is the stage for utopian imagination is another area of the study's investigation.

The dissertation introduces the question with a look at the problems associated with utopia. It considers utopian discourse in select works of each of these thinkers, paying attention to dystopian context, identification of style and language, subjectobject considerations, and the discursive treatment of space and time. In particular, it traces the theme of messianic expectation, 
in a loose secular sense, through this discourse. Finally, it links the way the messianic theme provides content to the idea of utopia present in this discourse. It claims that the messianic idea thematizes a materialist interpretation of transcendence and metaphysical experience that is developed in the work of each of these authors. That is, these authors locate the metaphysical moment necessary for the idea of utopia in the transcendent relation of the material subject to the subject of language and thought; in its concrete difference from that subject. This materialist moment provides a base for a non-representational and transformative approach to utopian imagination and perhaps even utopian practice, by linking the idea of "utopia" to a nonlinguistic understanding of the negation of suffering. 
TABLE OF CONTENTS

PAGE

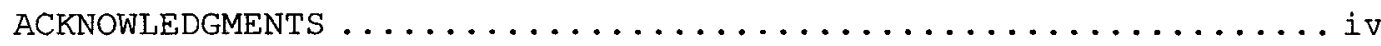
ABSTRACT CHAPTER

I. MISE-EN-SCENE. .........................

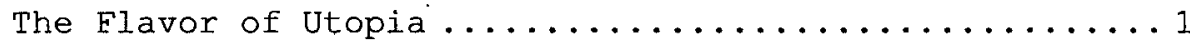

Terminology $\ldots \ldots \ldots \ldots \ldots \ldots \ldots \ldots \ldots \ldots \ldots \ldots \ldots \ldots \ldots \ldots \ldots \ldots \ldots$

Backstory - Established Features of Utopia ........13

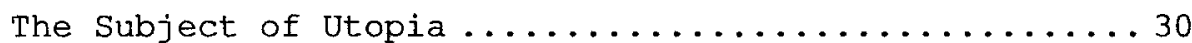

Utopian Discourse in the Theatre of the Humanities ... 32

Relevance of Utopia in the Late $20^{\text {th }}$ Century ........36

Reasons for the Choice of These Thinkers.............

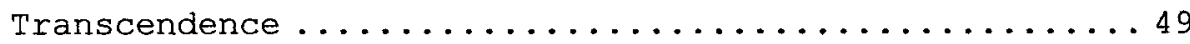

The Matter of Messianic Light ................. 51

Plan of the Work and Key Issues .............. 56

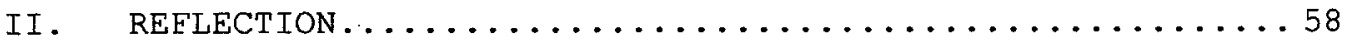

The Universal Guilt Context ................61

Adorno's Philosophical Aim ...................... 67

The Relation of Utopia to Adorno's Work ............74

The Actuality of Philosophy.................. 77

Utopia in Negative Dialectics................ 84

Physicality and Suffering..................... 91

Semblance and Second Reflection in Aesthetic Theory.. 93

The Concept of Utopia.................... 98 
Subjectivity and Its Objective Content..........99

The Myth of the Constitutive Subject.......... 102 Conceptual Commitment as Utopian Discourse ....... 105

Textual form as Utopian Discursive Practice ........ 107

Adorno's Critique of Language ............... 113

The Subject of Utopia $\ldots \ldots \ldots \ldots \ldots \ldots \ldots \ldots \ldots \ldots \ldots \ldots \ldots \ldots \ldots$

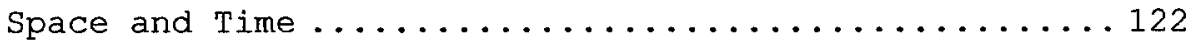

Adorno's Reader as a Subject of Possibility ........ 126

III. $\quad$ RADIATION. . . . . . . . . . . . . . . . . . . . 129

Dystopian Repression and Response ............. 132

Utopia in Irigaray's Work ................. 139

A Utopian Ethical Vision................... 139

Love's Negative Dialectical Labor............. 146

Sharing an Intersubjective World by Way of Love.... 151

Features of Irigaray's Utopian Scene ............ 165

Theory as Praxis ......................... 165

Mimesis, Poiesis, Hypnosis ................... 168

Woman-as-Subject as a Condition for Utopia ........ 172

Pursuit of Unalienated Language ............. 176

Treatment of Space and Time $\ldots \ldots \ldots \ldots \ldots \ldots \ldots \ldots \ldots \ldots \ldots \ldots$

Unresolved Questions ..................... 186

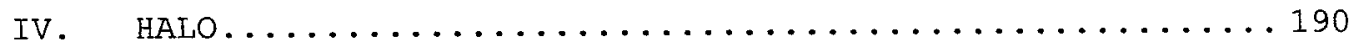

Introduction ......................... 190

A Preliminary Note on Gender.............. 196

Dystopian Vision - Spectacular Society ........... 198

Agamben's Theoretical Project................ 204

Agamben's Interest in Language.................. 207

Identity and Community..................... 209 
Vocation, Inoperativity, and Profanation.........211

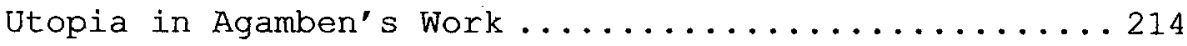

The Coming Community of Whatever Being......... 217

"The very topia of things"................ 220

Anthropological Machine out of Order...........225

Agamben on Messianic Time in The Time That Remains.. 231

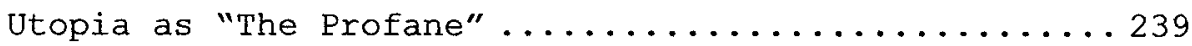

Philosophy as Strategy and Intervention .......... 240

Textual Form and Considerations of Language ....... 242

The Problem of Language from a Utopian Perspective... 244

Treatment of Subject-Object Relationship ......... 251

The Space and Time of Potentiality ............ 255

The Outside Inside...................... 256

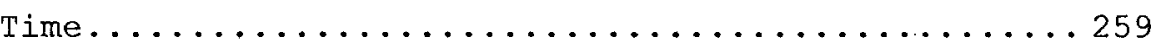

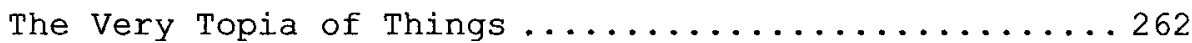

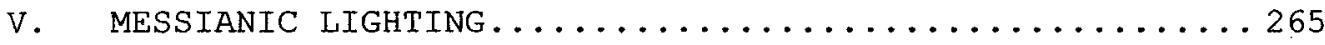

Introduction - The Subject of Utopia ........... 265

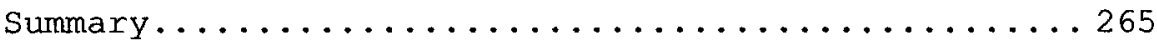

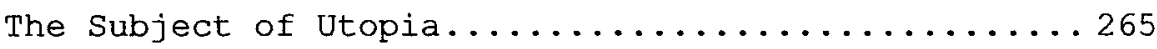

Critical Comparisons ................... 268

One Dystopian Assessment in Three Parts..........268

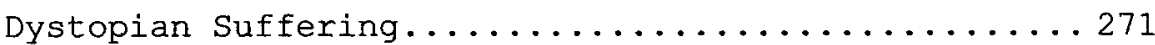

Critical Assessments of These Dystopian Accounts... 272

Common Calls for Disruption and Resistance....... 277

A Shared Critique of Language................ 282

A Subject Capable of Transformation............. 284

Review and Commentary.................. 287

The Chronotopic Subject of Possibility ........... 290 
The Event of an Outside as Potentially Utopian Space 291 Minimal Material Metaphysics ................ 296 A Preliminary Transformative Mode of Utopian Discourse298 "Messianic Light" as Practical Criterion .......... 301 Post Script: The Work of Messianic Lighting ........ 303

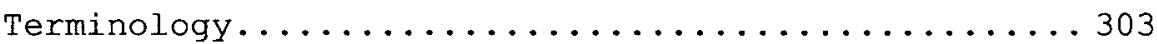
Working with Available Light..................... 306 REEERENCES ................................ 307 CURRICULUM VITAE $\ldots \ldots \ldots \ldots \ldots \ldots \ldots \ldots \ldots \ldots \ldots \ldots \ldots \ldots \ldots$ 
CHAPTER I

MISE-EN-SCENE

\section{The Flavor of Utopia}

In 1948, Marcia Brown's retelling of an old European folk tale earned her the first of her many Caldecott citations and medals. As she tells the story, three weary, hungry soldiers returning from war and still far from home trudge into a little town; their pleas for hospitality are denied by the self-interested villagers. The soldiers then ask for the use of a pot, some water, and three stones - to make stone soup. Little by little, they persuade the curious and unbelieving villagers to contribute a bit of this and a bit of that: a couple of carrots, a head of cabbage, even some meat. At last, they share the tasty and plentiful stone soup, occasioning a general festival; the soldiers spend the night in the best beds in the village, and depart the next morning to exclamations of gratitude. ${ }^{1}$

Despite first appearances, the story of stone soup is not a story of making something from nothing. It is more precisely a story of making something from something: ordinary soup from the ordinary ingredients of soup. The recipe for stone soup calls for mobilizing and realizing present possibilities, albeit possibilities that are blocked by the situation. Stone soup is possible soup that is, under the

1. Marcia Brown, Stone Soup (New York: Simon and Schuster, 1947). It seems unlikely that the story's Christian subtext, from the search for room and food at the beginning to the naming of the three soldiers as "wise men" at the conclusion of the tale, is entirely coincidental in this text composed by a Baptist minister's daughter. 
circumstances, impossible. Its impossibility under the circumstances makes its being something extraordinary the precondition for its being anything, however ordinary, rather than nothing. The completely possible, ordinary soup becomes possible, but only in the form of the extraordinary, completely impossible stone soup. The soup's very impossibility is the indispensable ingredient that produces its possibility.

As a tale of impossible social felicity made possible, stone soup has a utopian flavor. It smacks of the anticipatory utopian consciousness that according to Ernst Bloch surfaces persistently in every cultural medium, from dreams and innocent entertainments to developed programs for radical structural change. ${ }^{2}$ Its ingredients - art, in the form of illustrated text; religion, condensed in symbols and allusions; images of subjective agency and collective action - make it an appetizing introduction to a longer rumination on utopian discourse.

That longer meditation concerns the works of another trio of thoughtful practitioners of possibility: Theodor W. Adorno, Luce Irigaray, and Giorgio Agamben. It finds in these thinkers' texts the construction of a "subject of possibility" capable of utopian imagination and striving. This subject of possibility differs from the classical subject of the western humanities, but can nevertheless assemble and be informed by fragments of utopian promise. This subject can, moreover, undertake the practice of cultivating the consciousness to which those fragments give rise, and of elaborating their promise. The discursive appeal to and construction of this subject of possibility constitutes a timely mode of utopian discourse. Whether

2. Ernst Bloch, The Principle of Hope, Vol. 3, trans. Neville Plaice, Stephen Plaice, and Paul Knight (Cambridge, MA: MIT Press, 1996). 
that discourse, in effect, promises to make something from something in the manner of stone soup, is the ultimate question of this study. This first chapter introduces and outlines a rationale for the presentation that follows. It first discusses the way this text uses the terminology of "utopia" and "utopian discourse," and identifies some recurrent themes connected with the idea of utopia. It then discusses reasons for undertaking an examination of utopian discourse, and for considering these thinkers' utopian discourse in particular. Einally, it outlines the plan of the subsequent work, and identifies the key issues that will structure the consideration of the individual thinkers' texts.

Terminology

"Discourse" - In General

For the purposes of this project, "discourse" designates text that represents ideas, and that generates those ideas in the course of representing them.

Walter Benjamin claimed that all philosophy is "a struggle for the representation of ideas."3 "Discourse" appears here as the medium of that struggle, and the form in which its contending representations appear. This project thereby affirms the possibility and value of treating discourse as a representational form in the utopian case, despite the ongoing "crisis of representation" that qualifies Benjamin's claim, and that affects the appropriation of discourse by postmodern readers. ${ }^{4}$

3. Walter Benjamin, The Origin of German Tragic Drama, trans. John Osborne (London: Verso, 1998) 37.

4. There is by now a vast literature treating issues around representation raised by postmodern understandings of text. For the early attack on representational theories, see Jacques Derrida, Writing and Difference, trans. Alan Bass (Chicago: University of Chicago Press, 1978). A useful summary discussion of issues related to representation is Pauline Marie Rosenau, PostModernism and the Social Sciences: Insights, Inroads and Intrusions (Princeton: 
The sense of "discourse" as relatively extensive textual treatment of some subject matter has long been familiar to the humanities. ${ }^{5}$ The use of the term "discourse" here sets this project in that Eramework first of all, in contrast to one or another of the methods of discourse analysis that characterize linguistics or cultural studies. ${ }^{6}$ It signals the use of a method that consists of a reading of text oriented by a motivating concern, in this case by the question "What do these texts say about [the idea of] utopia?"

Nevertheless, this project also embodies an understanding of this discourse as participating in a larger discourse, in the sense of a larger body of enunciations, more or less loosely governed by rules of expression, which actively accomplish effects in a social milieu. That understanding of discourse takes as given the sense of discourse as generative or effective, which analysts since Foucault have brought to the usage of the term discourse. Thus, while this project looks most

Princeton University Press, 1992). Helpful discussions of the relationship of representational issues to text and interpretation occur in Teresa L. Ebert, "Review: The Crisis of Representation in Cultural studies: Reading Postmodern Texts" American Quarterly 38 (Winter, 1986) 894-902; Jeffrey T. Nealon, "Thinking/Writing the Postmodern: Representation, End, Ground, Sending" boundary 2 20 (Spring, 1993) 221-241; Steven Ward, "The Revenge of the Humanities: Reality, Rhetoric, and the Politics of Postmodernism" Sociological Perspectives 38 (Summer, 1995) 109-128; Michael Rothberg, Traumatic Realism: The Demands of Holocaust Representation (Minneapolis: University of Minnesota Press, 2000); George Hartley, The Abyss of Representation: Marxism and the Postmodern Sublime (Durham: Duke University Press, 2003).

5. For one relatively recent and illuminating example of this usage, see Barbara Herrnstein Smith, "On the Margins of Discourse," Critical Inguiry 1, no. 4 (1975): 769-798.

6. A general introduction to discourse analysis as used in the field of linguistics is Gillian Brown and George Yule, Discourse Analysis (Cambridge: Cambridge University Press, 1983), where it generally refers to the specialized analysis of language in use, in contrast to the analysis of more formal properties of language considered in the abstract. The specialized method of critical discourse analysis, or CDA, which has been seen as a boon to cultural studies, is outlined in a number of sources by Norman Fairclough and others, including Lilie Chouliaraki and Norman Fairclough, Discourse in Late Modernity: Rethinking Critical Discourse Analysis (Edinburgh: Edinburgh University Press, 1999). General introductions to discourse and discourse analysis which include assessments of the contribution of Michel Foucault's influential methods, and which emphasize the reading of texts prevalent in the humanities, include Diane Macdonell, Theories of Discourse: An Introduction (London: B. Blackwell, 1986) and Sara Mills, Discourse (New York: Routledge, 2004). 
closely at specific textual instances from the larger utopian discourse of the late $20^{\text {th }}$ and early $21^{\text {st }}$ centuries, it accepts certain basic understandings that stem from the perception of discourse as a socially productive site of the operation of power.

These premises have been outlined with particular clarity and concision by Samuel R. Delany in an article that also constitutes a reflection on the content of utopia and on the relationship of that content to language and desire, "The Rhetoric of Sex, the Discourse of Desire."7 These premises identify discourse as fundamentally linguistic, structured, constructive, directive, and pervasive. In particular, this understanding of discourse takes seriously the view that people come to understand what is being discussed, and to become able to recognize it as a phenomenon of their world, by reading about it, participating in conversations about it, and drawing inferences about it on the grounds of the statements made and not made in the discourse. Implicit rules that govern what meanings a particular word can and cannot assume, how a particular word can and cannot be used in utterances that remain intelligible, and which other words a particular term can and cannot intelligibly combine with, constitute part of the operation of discourse. The idea that the operation of discourse is one of the routes both for the constitution and the contestation of power, and one of the vehicles for the exercise of power, is running in the background throughout this project. ${ }^{8}$

7. Samuel R. Delany, "The Rhetoric of Sex, the Discourse of Desire," in Tobin Siebers, ed., Heterotopia: Postmodern Utopia and the Body Politic (Ann Arbor: University of Michigan Press, 1994) 229-272.

8. The basic theory linking discourse to power stems from the work of Michel Foucault. Representative works would include the early the order of Things [(London: Routledge, 1989)], and the late History of Sexuality [Volume 1: An Introduction, trans. Robert Hurley (New York: Vintage Books, 1990)]. Foucault's early critics concentrated on the tendency of this understanding of discourse to dissolve useful lines of meaning mapped on to terminology, seen as important for the pursuit of political projects. See for instance Nancy Fraser, "Michel 
Methodologically this project relies on a kind of hermeneutical "coasting," in the metaphorically nautical sense. It proceeds by staying within sight of the shoreline of the surface meaning of the text, with occasional stops for some limited etymological or philological exchange. It recognizes, in order to avoid, the deeper discursive waters trolled by archaeological, genealogical, or deconstructive methods. In essence, it presents something approaching a motivated commentary - an antique creative form, associated with forms of contemplative reading practices characteristic both of religious communities and of modernist aesthetics - on these texts. ${ }^{9}$

Nevertheless, this method takes seriously the perspective that discourse is a form of text-making that directly and indirectly produces the referents around which it fabricates its texts. In that sense, discourse and the making of texts are related to textiles, and to the arts or crafts of transforming fibrous raw materials into substances with visible surfaces that sometimes have utilitarian functions as well as specific aesthetic effects. ${ }^{10}$ One of the central

Foucault: A 'Young Conservative'?" Ethics 96, no. 1 (1985): 165-184, and Roger Paden, "Foucault's Anti-Humanism" in Human Studies 10, no. 1 Foucault Memorial Issue (1987): 123-141. From the standpoint of this project, however, Foucault's importance lies in the insight that power operates impersonally and discursively, and in the applicability of that insight to various fields of discourse, such as "fine art" or "religion."

9. On commentary as a creative form, see Giorgio Agamben, Infancy and History: On the Destruction of Experience, trans. Liz Heron (London: Verso, 2007), 160. On the relationship of commentary to the practice of religious reading, see Douglas Griffiths, Religious Reading: the Place of Reading in the Practice of Religion (Oxford: Oxford University Press, 1999). On contempoxary secular efforts to revive commentary as a creative form, see Glossator: Practice and Theory of the Commentary 1 (Fall, 2009), http://ojs.gc.cuny.edu/index.php/glossator/issue/view/37, and in particular Nicola Masciandaro, "Introduction," Glossator 1(Fall, 2009) i-ii, http://ojs.gc.cuny.edu/index.php/glossator/article/viewFile/510/552 (accessed May 16, 2010).

10. Etymologically, contemporary English terms "text" and "textile" both derive from Latin texere, to weave. Until recently, a "textile" denoted that type of "fabric" produced by weaving. "Fabric," which derives from the Latin faber, workman, could be produced by any of a number of methods other than weaving, such as knitting, felting, or crocheting. Contemporary usage, which 
questions of this project concerns the qualities of the idea "utopia" that emerges from these participants' discourse around utopia.

Furthermore, insofar as this dissertation extends and elaborates the discourse it studies, it does so as a self-conscious participant in that discourse. For that reason, this discussion of discourse may also be the place to mention - more accurately to confess - the guilt borne by this project, and its own form, in relation to the works it analyzes. All discourse has some particular, identifiable form, form being one of those things that cannot take place "in general," but only in some particular or other. An integral feature of all the works being considered here is a principled break with certain conventional forms of totalizing discourse, embodied paradigmatically by the academic treatise. Subjecting these works to a study presented in that form resembles a prima facie admission to not even having learned the first thing from them, if not a willful repudiation of their wisdom. Pointing out that these thinkers' works have all already been subjected to more than one full-length academic study only constitutes the preschooler's defense of "They started it," which is inevitably met with the grownup's answer, "Then you could have ended it."11 The argument that the linear treatise form is kinder to the reader, a fact amply documented by the texts under consideration themselves, merely diffuses the guilt without mitigating it.

makes "textile" and "fabric" functionally synonymous, suppresses the ancient distinction of the "weaver" versus the all-embracing "worker."

11. See, for example, Susan Buck-Morss, The Origins of Negative Dialectics: Theodor W. Adorno, Walter Benjamin, and the Frankfurt Institute (New York: The Eree Press, 1977); Margaret Whitford, Luce Irigaray: Philosophy in the Feminine (London: Routledge, 1991); Penelope Deutscher, A Politics of Impossible Difference (Ithaca, NY: Cornell University Press, 2002); Catherine Mills, The Philosophy of Agamben (Montreal: McGill-Queens University Press, 2008); Leland de la Durantaye, Giorgio Agamben: A Critical Introduction (Stanford: Stanford University Press, 2009). 
What hope for forgiveness in this matter may remain rests in the narrow topical delimitation on which the dissertation form takes its stand. The form of a whole assumed by a dissertation normally incorporates a tacit recognition of its strictly partial character with respect to that elusive knowledge that might justly lay claim to wholeness. It frequently constitutes, as it does in this particular case, something preliminary as well, however ultimate it appears from at least one standpoint. ${ }^{12}$ The claim to totality being made here extends only as far as the boundaries of the project, which have tried to respect the spirit of Tolstoy's moral advice. ${ }^{13}$ For that reason the presentation here may, as will be hoped, constitute more a clumsy than an iniquitous departure from its teachers' instruction, metaphorically speaking

\section{Specifically Philosophical Discourse}

The discourse to be considered here is specifically philosophical discourse. This is not automatically the case in a study of utopian discourse, and deserves a brief word.

Benjamin's insistence that philosophy concerns itself with the representation of ideas implies that even philosophical discourse is intrinsically, albeit highly abstractly, aesthetic. The philosophers under consideration here would share this view. That common outlook is one reason to devote attention to their presentational concerns and strategies.

Philosophy is a refuge for utopian thinking in the late $20^{\text {th }}$ and early $21^{\text {st }}$ centuries. One argument that resurfaces in this study is that

12. "Every new beginning comes from some other beginning's end." Dan Wilson, "Closing Time," in Semisonic Feeling Strangely Fine, MCA UK ASIN B0000062XN.

13. Tolstoy gives a lot of moral advice. The reference here is to the advice implicit in the dramatic meditation on the ultimate futility of overreaching, "How Much Land Does a Man Need?" Leo Tolstoy, "How Much Land Does a Man Need?" in How Much Land Does a Man Need? and Other Stories, trans. Ronald Wilks (London: Penguin, 1993) 96-110. 
the dystopian challenges of the $20^{\text {th }}$ and $21^{\text {st }}$ centuries are consequences

of basic patterns of thought. Philosophy is not necessarily a

liberating practice. Nevertheless, the radical reformation of

dysfunctional basic thought may constitute a pro-utopian political

practice, particularly insofar as it creates space for engaged utopian

expectation or imagination. In this respect, philosophy is a discipline

much like architecture, all the more so because basic thought is

something frequently encountered in a distracted and routine state. ${ }^{14}$

These philosophers are each engaged in investigations that have to do

with pushing the limits of what thoughts can be represented in the

philosophical representation of ideas, given the relationship of

philosophical discourse to its understanding as representation, or to

the way philosophical forms come to be translated into ideas by readers

of texts. In a sense, these are philosophical texts that deal with the

philosophical equivalent of architectural problems like spanning long

rivers or deep gorges or attaching habitable buildings to the sides of

hills. Agamben's assertion that "only in the burning house is the

fundamental architectural problem apparent for the first time" links

that architectural figure to the basic problem of art in modernity, but

the metaphor could apply to philosophy as well. ${ }^{15}$

\footnotetext{
14. See Walter Benjamin, "The Work of Art in the Age of Mechanical Reproduction," Marxists.org, www.marxists.org/reference/ subject/philosophy/works/ge/benjamin.htm, XV. According to Benjamin, architecture is appropriated in a state of distraction. Here we are looking into the "architecture" of western thought. The metaphor of architectural revision makes a radical - in the etymological sense - claim. The task is to move the bearing walls of thought.

15. Giorgio Agamben, The Man Without Content, trans. Georgia Albert (Stanford: Stanford University Press, 1999) 115. Adorno includes comments about functionalism in modern architecture as illustrative of the basic problem of locating truth in a balance of elements, when it sometimes requires a heightening of extremities. See Theodor W. Adorno, Aesthetic Theory, trans. Robert Hullot-Kentor (Minneappolis: University of Minnesota Press, 1997) 44. Irigaray talks enough about architecture, particularly in the context of the Heideggerian house of language, to have inspired architectural texts devoted to her implications for architects. See Peg Rawes, Irigaray for Architects (Oxford: Routledge, 2007).
} 
This focus on philosophical discourse affects the understanding of utopia that appears in this study. Utopia is most often understood as a fictional narrative form, and is sometimes defined as such. ${ }^{16}$ This study, however, focuses specifically on the emergence of utopia in philosophical discourse, what Irigaray calls "the discourse on discourse."17

\section{"Utopia"}

The understanding of discourse outlined above informs the use of the term "utopia" in this project. For the purposes of this text, "utopia" names an idea. If, as Walter Benjamin claimed, philosophy is a struggle over the representation of a certain number of words, or names for ideas, "utopia" is the name under consideration here. ${ }^{18}$ Philosophers and their allies have struggled over the definitive or dominant representation of that idea at least since the word was introduced to the English language by Thomas More in 1516.

While the representations of the idea named "utopia" vary, their contents and descriptions typically cluster near one or another of the twin rubrics given by the dictionary: either a "state, condition or place of ideal perfection" or a "visionary, impractical scheme for social improvement."19 The philosophical struggle over the representation of the idea of "utopia" entails in particular the discourse that positions the word closer to one of those poles than the other, that attributes this or that determinate content or characteristic to the state or condition named "utopia," that suggests

16. Krishan Kumar, Utopianism. (Minneapolis: University of Minnesota Press, 1991).

17. Luce Irigaray, This Sex Which is Not One, trans. Catherine Porter with Carolyn Burke (Ithaca, NY: Cornell University Press, 1985) 74.

18. Walter Benjamin, ibid.

19. Funk \& Wagnalls Standard College Dictionary (New York: Harcourt, Brace \& World, Inc., 1966). 
what might be entailed in bringing about its ultimate achievement, and that says which attitudes towards that achievement would be appropriate. Understanding "utopia" this way emphasizes its nominal character. That emphasis postpones some problems of reference that arise when utopia is considered differently. If "utopia" is taken to designate a substantive, a "state, condition, or place," the question of its ontological status can quickly take center stage. Utopia as an existential or empirical entity can, however, appear only as a lack or an absence, at best a phantasm, in any event "meaningless" or oxymoronic from an analytical perspective, and disqualified a priori as an object of knowledge or, even more controversially, truth. Asking about the properties of such a non-entity would be incoherent; asking whether those properties are desirable or not would be ludicrous. If the emphasis rests on "utopia's" status as a place of "ideal perfection," debates about the accuracy of that epithet, based on this or that property, can derail a preliminary inventory of qualities. If "utopia" purportedly designates some potentially realizable state or condition, a number of other distracting questions, related to the problem of passing from imaginary to actual, arise. Attention shifts to whether "utopia" already actually exists in an alternative space, might actually exist but does not exist at present, simply ought to exist, if so where it exists, and so on.

Emphasizing "utopia's" nominal character only postpones, rather than resolves, all these essential ontological, ethical, and political problems, which lie beyond the scope of this study. Eventually, all the questions return, as questions about the status of the object of discursive representation, or about the relationship of discursive representation to an actual or imaginary entity, or the criteria for the defensibility of a given representation, or the relationship of 
some discursive treatment to this or that praxis. Before they do, however, this study of some specific properties of a portion of the discourse around utopia will, it is hoped, have had time enough to glean its insights.

This text, then, avoids the general question of the relationship of an image to an empirical model. It does not attempt to determine whether a specific proposed arrangement does or would actually constitute a realization of utopia, in the sense of a concrete state or condition in which people are actually happy. It sets aside questions related to the accurate assessment of utopian claims. Instead, it confines itself to an examination of how three thinkers have treated the idea of utopia, and in particular how they have constituted the subject of utopian discourse and practice, in select works. ${ }^{20}$

The nominal treatment of utopia outlined here also constitutes a departure from the study of utopia as a form of fictional narrative or as a form of social experiment. An argument implicit in this project is that the utopian idea can, and does, emerge in forms other than that of narrative fiction or experimental enclave. It also surfaces as a vital reference point in the philosopher's struggle to "think the break" with the context of philosophy from within that context. ${ }^{21}$

20. Avoiding the question of the assessment of utopian claims is not meant to suggest that the question itself is not important. A good argument might be made that it is perhaps the most important question related to utopian discourse. It is not, however, the first question, nor the question this dissertation sets out to answer.

21. Adorno claims dialectics is the effort to break out of the objective context of delusion from within. Theodor $W$. Adorno, Negative Dialectics, trans. E.B. Ashton (New York: Continuum, 1995), 406. Fredric Jameson argues that the function of the utopian text, understood as a developed fictional form in contrast to political exhortation or "great prophecy," is to force its readers to "think the break" that constitutes the imaginable alternative to a closed system of reference presented as having no other. Fredric Jameson, Archaeologies of the Future: The Desire Called Utopia and other Science Fictions (London: Verso, 2005), 231-232. 
Even this nominal treatment does, however, sometimes register a second sense of the term "utopia." Normally, "utopia" in this text names the idea, represented in discourse, of a state, condition, or place with desirable properties, variously described. Occasionally, however, "utopia" can designate a projected cultural achievement. That cultural achievement typically takes the form of a pattern of social relations, that is being pursued in light of some version of that idea. This concession finally proved unavoidable. The idea named "utopia," as represented in utopian discourse, frequently includes the element of its own cultural or political achievement. From time to time, then, it becomes necessary to mention the ineluctably related idea of people's wanting or trying to achieve it, for instance by undertaking an intentional utopian praxis, or by acting in the direction of "utopia." In general, formulations like "utopian striving" or "utopian praxis" refer to the pursuit of "utopia" as an achievement, one that takes the form of a pattern of social relations. Making reference to that pursuit does not automatically imply a conviction that any particular pursuit of utopia could or would succeed, or that the particular version of utopian achievement pursued is actually worth pursuing. It points out that sometime, somewhere, someone might have some conviction like that, and might do something about it.

While "utopia" names an idea, "utopian discourse" does not necessarily invoke that name. This project has paid attention first of all to these thinkers" explicit references to "utopia." Its goal has been to situate those references within the context of each thinker's project, and to discern the relationship of each thinker's treatment of the idea of utopia to that project. In pursuing that goal, it has drawn as well on texts that contribute to the communication of an idea that might aptly be named "utopia," even where that idea appears incognito. 


\section{Backstory - Established Features of Utopia}

The notion that an idea can appear incognito only makes sense if there are criteria for recognizing that idea other than by name. Criteria like that can arguably be provided by the idea's historical associations, in the case of an idea with a history. The idea of utopia does have a history, beginning with its appearance in Thomas More's fictional Utopia. Some content has been assigned to the idea of utopia in the course of that history, and constitutes a starting place for developing something like a field guide to the utopian concept. That guide to the utopian concept will help in discerning utopian themes as they "flit through" the work of Adorno, Irigaray, and Agamben, or as they come together to form a "legible constellation" that amounts to utopian discourse in texts that avoid the name of utopia. ${ }^{22}$

The field guide developed here emphasizes some aspects of the utopian tradition more than others. This section provides some additional background for the utopian features that play the largest part in the reflections that follow. These include three features in particular: the relationship of utopia to place and time; recurrent themes in utopia's characteristic content; and the extent to which utopia itself can become the object of representation. With respect to the content of utopia specifically, the discussion focuses on the three rubrics of "happiness," "desire," and "the negation of the negative," or the idea of "suffering overcome."

Utopia as Place

Utopia is ineluctably associated with space and time, as "place." The very name "utopia," as is widely known, derives from the Greek topos (place), which compounded with the Greek negation ou (no, not)

22. Theodor Adorno, Minima Moralia: Reflections from Damaged Life, trans. E.F.N. Jephcott (London: Verso, 1974) 87; Negative Dialectics, 407. 
reads more or less literally "no-place." ${ }^{23}$ Thomas More himself announced the play on words encoded in the Greek source of the name by voicing the wish that this Utopia, no-place, might some time become a Eutopia, good place. ${ }^{24}$ Less often mentioned by commentators is another Greek possibility, iou, a genitive signifying "of poison" or "of rust," which could make of the yet-to-be-decided u-topia someplace even more negative than no place at all.

The identification of utopia with a fictional place does not resolve the question of the relationship of utopian place to that which its audience inhabits, even when one takes into account "the well-known shift in Utopias from space to time, from the accounts of exotic travelers to the experiences of visitors to the future." 25 In particular, the question perennially arises of whether utopia could coincide with the place and time of "here and now" or "the real world."26 The problem with every potential answer lies not only in the indeterminacy of utopia. The place and time of the "here and now" or "real world" is at least equally complicated by its discursive associations. Jameson has asserted that utopia relates to the present as "disruption," in its function of forcing an imaginative engagement with the rupture between what appears to be a closed system of signification (the here and now, the ideologically-specified real world) and any utopian alternative. ${ }^{27}$ The practical political question of the relationship of utopian space

23. The place name Utopia did not "literally" mean "no place" in the English of its day, while in Greek $u$ tonos is literally incomplete. Louis Marin reads this nominal undecidability as different from ambiguity, which would apply to a "univocal name," and as signifying the operation of the specifically utopian form of neutrality. Louis Marin, Utopics: Spatial Play (Atlantic Highlands, NJ: Humanities Press, Inc., 1984), 91 . 27 .

24. Thomas More, Utopia, trans. Paul Turner (London: Penguin Classics, 1965)

25. Jameson, ibid., 1-2.

26. See among others J.C. Davis, Utopia and the Ideal Society: A Study of English Utopian Writing 1516-1700 (Cambridge: Cambridge University Press, 1983); Marin, ibid.; Kumar, ibid., 25; Jameson, ibid.

27. Jameson, ibid., 231-2. 
and time to the place of what people popularly take to be the real is evaded by a utopian "secession" that marks the utopian text's otherness, and that permits - indeed, that forces - a "thinking of the break" that would be effectively repressed within the dominant symbolic order if it were to take another form.

Michael Rothberg argues that Adorno's use of the term "nach Auschwitz," after Auschwitz, generates a new, specifically late modern and potentially postmodern chronotope. That is, it constitutes the "simultaneity of spatial and temporal articulations in cultural practices" that was the essence of Mikhail Bakhtin's organizing concept of chronotope. ${ }^{28} \mathrm{~A}$ similar argument applies in the case of utopia. The mention of "utopia" functions chronotopically, as a fusion of space and time that establishes both an essential discontinuity and an essential continuity. The discontinuity of the utopian with the "here and now," as being not-(here-and-now), highlights the contrast of utopia with the space-time of the here-and-now. Nevertheless, utopia always entails an essential and inescapable failure of discontinuity, because this negation of the here-and-now is nevertheless known and knowable, and is for that reason precisely not the full negation of the here-and-now. ${ }^{29}$ Like a single character in a television farce impersonating another, so that both characters cannot appear together in space and time without catastrophic dénouement, the utopian chronotope is constructed around a removal from "real" space and time along at least one, if not both, dimensions. This utopian removal, however, which presents itself as a complete antithesis of the situation of its enunciation, always

28. Michael Rothberg, Traumatic Realism: The Demands of Holocaust Representation (Minneapolis: University of Minnesota Press, 2000). On the concept of the chronotope, see Mikhail Bakhtin, "Forms of Time and the Chronotope in the Novel: Notes Toward a Historical Poetics," in The Dialogic Imagination: Four Essays, ed. Michael Holquist, trans. Caryl Emerson and Michael Holquist (Austin: University of Texas Press, 1981) 84-258.

29. Jameson, ibid., in particular 170-181. 
incorporates a specific relation of accessibility to this situation. Its here-and-now audience can imagine itself there-and-then, by a corresponding, determinate displacement - e.g., an earlier or later birth date, or a trip to the distant location - that leaves its hereand-now consciousness unaffected, but for its access to the utopian scene. Utopia thereby depends upon its depiction as accessible to inhabitants of the here-and-now, though exclusively in an imaginative way.

The innate connection of utopia to place and time makes it reasonable to check for the operation of utopian discourse in the way issues of place and time surface in texts by Adorno, Irigaray, and Agamben. And as will become clear, while these philosophers do not address issues of space and time through the same narrative forms identified in Louis Marin's and Fredric Jameson's analyses of fictional utopian texts, these thinkers' utopian discourse reflects the chronotopic nature of utopia by operating in part through their treatment of the categories of space and time.

Utopia as the Place of Happiness

Since utopia as a chronotope is a place, a socially articulated corelation of time and space, the question arises as to what kind of place utopia is. One emphatic touchstone of the utopian place is happiness.

The specific association of the name utopia with the idea of a place of happiness is as old as Thomas More's suggestion that the state or condition that was "Utopia" or "No-place" actually qualified for the epithet "Eutopia" or "Good place," "Happy place." More explicitly links utopian happiness to the goals of the western philosophical and theological traditions, through his inclusion of a Utopian verse which 
asserts the superiority of Utopia over Plato's Republic. ${ }^{30}$ The happiness associated with utopia is the very happiness or flourishing, eudaemonia, that has been the goal of proper ethical and political order in the west since Plato's Republic and Aristotle's ethics. Utopia's claim to superiority is here secured on grounds reminiscent of the medieval theologian's ontological proof, the logic according to which the greatest good imaginable must exist, since the greatness of what can be thought apart from its existence is exceeded by the greatness of that which can be thought of as having existence. ${ }^{31}$ Since ultimately the contemplation of the greatest imaginable good entails eternal bliss, More's Utopia appears to point both to the philosophers' and the theologians' greatest imaginable happiness. ${ }^{32}$

Although some analysts of utopia emphasize the centrality of elements other than happiness as definitive of the utopian condition, happiness is a recurrent touchstone of the utopian. Fabulous hedonistic utopias, like the Land of Cockaigne or the Big Rock Candy Mountain, have their foundation in the unalloyed happiness that presumably consists in the complete and effortless fulfillment of physical needs. Ernst Bloch includes what he terms "Erench happiness," an intense state

30. Utopia priscis dicta ob infrequentiam / Nunc Civitatis aemula Platonicae, / Fortasse victrix (nam quod illa literis / Denlinavit, hoc ego una praestiti, / Viris et opibus, optimisque legibus) / Eutopia merito sum vocanda nomine. "The ancients called me Utopia or Nowhere because of my isolation. At present, however, I am a rival of Plato's republic, perhaps even a victor over it. The reason is that what he had delineated in words I alone have exhibited in men and resources and laws of surpassing excellence. Deservedly ought I to be called by the name of Eutopia or Happy-place." Thomas More, Complete Works (New Haven: Yale University Press, 1965), Vol. IV, 20-21; cited and translated in Marin, ibid., 91.

31. Utopia's detailed literary existence also resonates with one of the early objections to that logic. That objection, developed by an otherwise obscure Benedictine monk, Gaunilo of Marmoutiers, depended on the absurdity of thinking that the existence of a certain Lost Island, which came to be known as Gaunilo's Island, was proved by its status as the "most excellent" island. Gaunilo of Marmoutiers, "Pro Insipiente," in First Philosophy: Fundamental Problems and Readings in Philosophy, Vol. III God, Mind and Freedom, ed. Andrew Bailey (Orchard Park, NY: Broadview Press, 2004) 26-28.

32. Jaroslav Jan Pelikan, The Growth of Medieval Theology (600-1300) (Chicago: University of Chicago Press, 1978), 303. 
of the delight of the senses, and joy, the "aristocracy of happiness," as "images of the fulfilled moment" that describe the utopian imagination. ${ }^{33}$ Fredric Jameson cites the words of the doomed youth Arthur in Roadside Picnic as a "brief glimpse" of the "impossible and inexpressible Utopian impulse," albeit an impulse that cannot be disentangled in its literary form from its various anti-utopian complications: "HAPPINESS FOR EVERYBODY, FREE, AND NO ONE WILL GO AWAY UNSATISFIED! " ${ }^{34}$

Happiness, in other words, acts as one familiar and well-attested thematic marker of utopian discourse. Invocations of the realization of happiness, its pursuit, and its difficulty of achievement may for that reason signal the operation of utopian discourse. Examples would include Adorno's reference to "complete happiness," and its denial, in the concluding sections of Negative Dialectics, or Irigaray's projection of "a felicity within history" as one goal of a political praxis attentive to the implications of sexual difference. ${ }^{35}$

Seen in this way, as the land of happiness, utopia emerges as the end not only of influential currents in the western intellectual tradition's ethical, political, and theological endeavors, but arguably also in its artistic or aesthetic practices. Where stendhal claims beauty is only the promise of happiness, Adorno identifies that promise as definitive of art generally. ${ }^{36}$ The happy utopian end of these

33. Bloch, ibid., 937.

34. Jameson, ibid., 295; Arkady and Boris strugatsky, Roadside Picnic, trans. Antonina W. Bouis, Cryptomaoist Editions, 126, http://www. cca.org/cm/ (accessed May 21, 2009).

35. Adorno, Negative Dialectics, 404; Luce Irigaray, I love to you: Sketch of a Possible Felicity Within History, trans. Alison Martin (New York: Routledge, 1996).

36. "Stendhal's dictum of art as the promesse du bonheur implies that art does its part for existence by accentuating what in it prefigures utopia." Adorno, Aesthetic Theory, 311. "Stendhal's dictum" is presumably the frequently-quoted definition of beauty found in the work on Love (De $l^{\prime}$ amour) by the $19^{\text {th }}$-century writer Marie-Henri Beyle, pen-name Stendhal, namely "La 
endeavors embodies the dual sense of end as aim and as culmination and conclusion.

That equation raises a concern about the identification of utopia with happiness. With respect to art, for instance, Adorno claims "If the utopia of art were fulfilled, it would be art's temporal end."37 Jameson notes that the putative "end of art" is part of the radical depersonalization and detemporalization that gives rise to concerns about Utopian boredom and "fear."38 whether the achievement of utopia would really spell the end of all art, it seems likely to entail the end of the novel.

The suspicion that happiness would put a stop to the effort, or struggle, embodied in art and other reflective activities stems from a particular - modern and postmodern - understanding of happiness. That understanding views happiness as the antithesis of alienation. For that reason, the experience of happiness seems to be at odds with the selfconsciousness required for conceptualization and activity, including the conceptualization of and the striving for utopia. Adorno, e.g., insists that the experience of happiness lies in the moment; it is perceptible only in retrospect, as something irretrievably past, and the "only relation of consciousness to happiness is gratitude: in which lies its incomparable dignity."39 Happiness, in this account, is an intrinsically unknowing experience that excludes what we think of as "consciousness," with its structure of the knowing subject, the known object, and the separation between them.

beauté n'est que la promesse du bonheur." (Beauty is only the promise of happiness.) For a discussion of the slippage between stendhal's "beauty" and Adorno's "art" see James Gordon Einlayson, "The Work of Art and the Promise of Happiness in Adorno," World Picture 3: Happiness, proceedings of the 2009 World Picture Conference, October 23-24, 2009, Oklahoma State University, http://www.okstate.edu/worldpicture/ (accessed March 22, 2010).

37. Adorno, Aesthetic Theory, 32.

38. Jameson, ibid., 182-184.

39. Adorno, Minima Moralia, 112. 
If Adorno is correct, and if utopia is taken to be a place of happiness, it affects the chronotopic character of utopia. To the extent that utopia is an experiential chronotope, an articulation of space and time that supports experience, and if the experience it supports specifically excludes "consciousness," the hallmark of the epistemological subject, the subject of knowledge, than utopia can have no knowing subject. From this perspective, that subject's relation to utopia is of a perpetual contemplation of the interior of the candy shop through the constitutive barrier of the shop window. Moreover, when utopia is understood strictly as a place of happiness, almost everything about utopia remains unspecified. Consulting the conditions for happiness, as these are given by the experience of happiness, provides a fragmentary and episodic account of Bloch's "images of the fulfilled moment," rather than the detailed specifications that are associated with utopia's familiar generic forms. The systematic efforts that have been made to analyze the conditions for happiness in the course of the elaboration of western ethics, politics, art, and religion, in seeking to grasp the universal or background conditions for a general happiness, miss the concrete, conjunctural, even idiosyncratic qualities of the modern experience of happiness.

The problem with happiness as the content of utopia is further complicated by the particularity of its social and historical determinants, again as seen from the vantage point of modernity. The chief goal of most civilization has been to ensure that those who fail to uphold the basic canons of commendable conduct will experience misery in this life and fearfully expect additional and overwhelming misery in whatever world may lie ahead. The thesis that civilization rises on a foundation of renunciation and alienation, and that the 
abandonment of this renunciation and alienation would promote the happiness or pleasure people associate with immediate gratification, already contains the germ of the insight that only within a particular, concrete social and historical conjuncture, private as well as public, do people acquire the affective and symbolic equipment to experience happiness as such. ${ }^{40}$ This history makes human happiness very largely if not entirely contingent on what society and our learning of it, through all available channels, has invested with the quality of being able to produce happiness. All particular utopian discourse will prove, on this argument, always already bound to the images of the fulfilled moment provided and authorized by the larger discourse of which it is a moment.

$$
\text { Utopia as Desire }
$$

The understanding that happiness is conjunctural and historically mediated has not always dominated discussions of happiness as it does today. ${ }^{41}$ However, the contemporary understanding of happiness points towards the need to consider desire, and its local determinants, in relation to the content of utopia. That exploration resonates with more recent thematizations of utopia as well.

Ruth Levitas proposed to define utopia as "an expression and exploration of desire" in her now-classic work the Concept of Utopia. ${ }^{42}$ In that work, Levitas argues the need for a definition that will accommodate the various formal treatments of utopia, from detailed utopian fiction to sociological analysis on the order of Mannheim's Ideology and Utopia, and that will span the different possible emphases evident in discussions of utopia. Earlier theorists had emphasized

40. Sigmund Ereud, Civilization and its Discontents, trans. James Strachey (New York: W.W. Norton, 1961).

41. Finlayson, ibid.

42. Ruth Levitas, The Concept of Utopia (Syracuse: Syracuse University Press, $1990), 191$. 
either form, content, or function; Levitas sought a definition that

would account for variations in these emphases across time. She concluded with the assessment that:

Utopia expresses and explores what is desired; under certain conditions it also contains the hope that these desires may be met in reality, rather than merely in fantasy. The essential element in utopia is not hope, but desire - the desire for a better way of being. ${ }^{43}$

Where Bloch had presented the principle of hope as the ubiquitous utopian principle in human culture, Levitas was willing to identify the expression of desire, even desire that knows itself to have no hope of fulfillment, as utopian.

Levitas' definition of utopia as desire, according to Fredric Jameson, was instrumental in transforming utopian studies into a coherent sub-discipline. ${ }^{44}$ That effect surely came, at least in part, from the peculiar resonance it established between a definition that made desire itself central and the postmodern preoccupation with desire itself as an object of fascination and contemplation. This preoccupation, in turn, stems from the status of desire as a phenomenon whose concept brings together Hegelian-dialectical roots, Lacaniandiscursive theoretical trajectories, and Debordian-spectacular, consumerist actualizations and implications. ${ }^{45}$ All contemporary understandings of desire emphasize its discursive character. Some lend credence to the position that postmodernity realizes the conditions for a "meta-utopian" condition in which different, even incompatible, utopian visions can be accommodated and pursued simultaneously. ${ }^{46}$

43. Ibid.

44. Jameson, Archaeologies, note p. 2-3.

45. Madan Sarup, An Introductory Guide to Post-Structuralism and Postmodernism, $2^{\text {nd }}$ edition (Athens, GA: University of Georgia Press, 1993), 17$26,93-97$.

46. See Leonard Harris, "Postmodernism and Utopia, an Unholy Alliance," in Racism, the City, and the State, ed. Malcolm Cross and Michael Keith (London: 
An acute fictional commentary on the notion of the desire-defined meta-utopia appears in Ursula K. LeGuin's "The Ones Who Walk Away From Omelas."47 In that story, "Omelas" appears initially as a selfconsciously utopian and explicitly meta-utopian construct; while it is almost impossible to describe, it is explicitly open to a variety of imaginative constructions and to significant pluralism of desire, along with its satisfaction. The problem with the meta-utopia of Omelas, however, is a single, central jarring element that vitiates its utopian claim in the eyes of the people who walk away. That problem is the society-wide conscious acceptance of a quantum of perpetual, constitutional suffering imposed on a speechless and uncomprehending other. The utopian solution in Omelas fails, at least from the perspective of the ones who walk away, precisely insofar as it founds itself on this suffering. LeGuin's tale dramatizes another, traditional, theme associated with the idea of utopia, which will prove central to the discourse studied here.

Utopia as the Negation of Suffering

Both the idea of utopia as a place of happiness and that of utopia as an expression and exploration of desire presuppose and include the idea of utopia as a place unmarred by suffering. This project, in particular, finds the negation of suffering to be paradigmatic with respect to the utopian discourse it explores. Sometimes, the idea of the negation of suffering appears directly. Importantly, however, insofar as utopia emerges as an image or representation of an idea related to happiness or desire, these representations also incorporate

Routledge, 1993) 31-44; Patricia J. Huntington, Ecstatic Subjects, Utopia, and Recognition: Kristeva, Heidegger, Irigaray (Albany: SUNY Press, 1998).

47. Ursula K. LeGuin, "The Ones Who Walk Away from Omelas," in The Wind's Twelve Quarters (New York: Harper \& Row, 1987) 275-284. The story was originally published in 1973. 
the negation of suffering, presented under the aspect of the negation of a negative as a positive. That is, utopian happiness, or utopian expressions of desire, inevitably emerge as positively tinged visions of the negation of suffering.

The negation of suffering itself in its utopian form, true to the chronotopic character of utopia, predictably fuses a temporal dimension with the site of utopia. Suffering may appear as "having been overcome at last" or "never again to be" or even - in the case of those utopias projected into the past - "not yet having been."48 It is arguably the temporal dimension ascribed to this negation, and in particular its imaginable prospective character, that has made the association of utopian imagination and ideas of "progress" or "revolution" as strong as it has sometimes seemed. Fredric Jameson's analysis, which finds the utopian form intrinsically non-programmatic or non-strategic, also comments on the unparalleled political interest that attaches to the utopian literary form. The persistent political relevance of utopia seems to depend precisely on this non-programmatic and emphatic display of an imaginable alternative to the "unspeakable world that is." ${ }^{49}$

Utopian negation of suffering stands in a clear relationship to the satisfaction of desire, even though it is not identical to that satisfaction. For that reason, recognizing utopia as the idea of the negation of suffering extends rather than abandons Levitas's insight into the desirous character of utopia. Desire has long been regarded as a form of suffering by philosophers and theologians. ${ }^{50}$ The etymological

48. For the notion of utopias projected into the past, see in particular Lewis Mumford, The Story of Utopias (New York: Boni and Liveright, 1922).

49. Jameson, ibid., 232; Adorno, Negative Dialectics, 403.

50. Stoics, Epicureans, and Buddhists agree that desire fuels the fires of suffering. See Martha Nussbaum, The Therapy of Desire: Theory and Practice in Hellenistic Ethics (Princeton: Princeton University Press, 1994); Susan R. Garrett, No Ordinary Angel: Celestial Spirits and Christian Claims About Jesus 
derivation of passion in the Greek verb pathein, to suffer, is reasonably well known. Utopia functions as the imaginative transformation of that desirous suffering, such that the "expression and exploration" of desire identified by Levitas amounts to giving a positive form to the negation of suffering. Suffering appears, then, as the material from which utopia takes its shape.

The material that is suffering has some peculiar characteristics, especially when compared with the accounts of desire given in the western theoretical tradition. Desire in that tradition arises from a specific lack of a desired object; that is, desire in its structure elaborates the relationship of subjectivity to absence. Most recently, the relationship of desire and lack has been theorized in Lacanian psychoanalytic thought. These theories, too, link desire to lack or absence. ${ }^{51}$ This original relationship gives rise to the question of whether a positive desire, based on pleasure or happiness without the mediation of suffering, is even possible.

By recognizing this relationship, the argument here is that issues of desire necessarily arise in conjunction with experiences of suffering, even if it is the awakening of desire itself that gives rise to the awareness of suffering. The choice to focus on the aspect of suffering and the involvement of suffering in the constitution of utopian discourse, however, in preference to that of desire has some important consequences. First, it responds explicitly to emphases present in these theorists' works, which take up suffering as an

(New Haven: Yale University Press, 2008); Roger Corless, The Vision of Buddhism: The Space Under the Tree (New York: Paragon House, 1990).

51. Elizabeth Grosz, Jacques Lacan: A feminist introduction (London: Routledge, 1990); Darian Leader and Judy Groves, Introducing Lacan (Cambridge: Icon Books, 2001); Jacques Lacan, My Teaching, trans. David Macey (London: Verso, 2008). 
explicit theme. More importantly, however, it shifts the terms of the question of the representation of utopia, and the concept of utopia.

The shift in terms is precisely that of a shift in what has to be represented, and the presence of concrete content in that representation. Desire, following Lacan, is a property of the symbolic order. Its movements are motivated within a symbolic system that only permits the operation of desire in an alienated and distorted way. There is a permanent schism between desire and need, or the counterpart of the Lacanian real, what would amount to the unthematized concrete. What this means in the case of utopian representation is that projections of the character or content of utopia themselves always already presuppose a particular, socially-imposed or regulated, systematization of what may be desired, what can appear as desirable. This will officially fail to disrupt the system itself, with its prohibitions and permissions. This will be true even, or perhaps especially, when it is the organization of this symbolic order that produces specific symptoms of suffering.

Suffering, on the other hand, anchors desire in the concrete and objective. As Adorno says, "suffering is objectivity that weighs upon the subject."52 Thus, while utopia does indeed "appear abstract amidst concrete things," its relationship to suffering invests this abstract image with an intrinsic and inescapable concreteness. ${ }^{53}$ Thus the very idea of utopia participates in the name-like structure of Adorno's "concept," or "thought," which contains in its innermost cell that which is not thought, not abstraction. ${ }^{54}$ This concrete cellular character of utopia, which it stubbornly maintains in every guise in

52. Theodor Adorno, Negative Dialectics, 83.

53. Ibid., 57.

54. Ibid., 408 . 
spite of its imaginary and abstract mode of appearance, constitutes a central feature of utopian discourse and remains at the center of the analysis here.

Suffering and its enformation in utopia further renders utopia, while abstract in its form as a negation of suffering, concrete in its contents as a body of suffering which concrete human subjects cry out to have negated. Following Ernst Bloch, and in contradistinction to post- or anti-humanist trends, this project takes seriously concrete individual human subjects, as sufferers, dreamers, and imaginers of alternatives. ${ }^{55}$ An underlying premise, which will be honored albeit sometimes tacitly and implicitly, is that the materialistically and pragmatically understood subject of the humanities, the human subject of such things as lost car keys, mortgage payments, and reading a bedtime story to a child, is deeply concerned in the prospects for utopian discourse, and whatever conceivable and possible pro-utopian activity. This concrete subject is neither, precisely, the universal subject of enlightenment reason, nor a collective subject, but is always whatever particular and concrete human subject, whose specific predicates or qualities matter, though they may or may not identify the subject in a definitive way. ${ }^{56}$ More to the point, this outlook with respect to the subject might be called a conventional understanding of the everyday and popular-philosophical understanding of the human subject. Difficulties with the theoretical formulation of this subject notwithstanding, this understanding amounts to an assertion that someone like this subject still has to be considered theoretically as

55. See in this regard Douglas Kellner, "Ernst Bloch, Utopia and Ideology Critique," Illuminations, http://wWw.uta.edu/huma/illuminations/kell1.htm (November 17, 2009).

56. The important subject of suffering, and of the concern with utopia, may then coincide with Agamben's "whatever singularity" as discussed in The Coming Community. Giorgio Agamben, The Coming Community, trans. Michael Hardt (Minneapolis: University of Minnesota Press, 1993). 
well as practically, and still ultimately has to be at least one of the actual subjects both of theory and of praxis.

Utopia as Unrepresentable

Russell Jacoby identifies a stream of utopian thought he labels "iconoclastic" utopianism that contrasts with what he terms "blueprint" utopianism. Jacoby's blueprint utopians are those that, like Thomas More, describe the utopian scene in minute detail. The iconoclastic utopians, in contrast, avoid detailed images. Jacoby theorizes that these utopians, deeply influenced by Jewish messianic thought and schooled by the Torah's ban on images, developed their utopian expressions in an anti-pictorial direction. He explicitly includes Theodor Adorno as an iconoclastic utopian thinker. For such utopians, the place of happiness is unrepresentable for reasons having to do with the need to avoid falsifying the picture of utopia by fixing it in a particular, static, and ultimately idolatrous form. ${ }^{57}$

Utopia is arguably unrepresentable for reasons beyond Jacoby's thesis, however. One argument is that utopia, to be different enough to be worthwhile, must be so different that its representation would be unintelligible. ${ }^{58}$ The prohibition on images may have been reimposed for historical and political reasons. On this argument, what can be expressed in the idiom of the current symbolic structure is ipso facto already reconciled to it and consequently offers no hope for its radical redemption. So utopian discourse itself has to borrow a page from Adorno's aesthetic theory: utopian discourse has to depend on texts that are utopian without talking about utopia, texts that paint the absence of the positive they want to evoke, or texts that explore

57. Russell Jacoby, Picture Imperfect: Utopian Thought for an Anti-Utopian Age (New York: Columbia University Press, 2005).

58. See Jameson, Archaeologies, 107-118. 
new modes of communication which, because they cannot rely on easilyunderstood linguistic forms, flirt with unintelligibility.

Utopian discourse for these philosophers constitutes and embodies a response to the threat to happiness posed by a premature closure of the world, a closure that results from fixation on prescribed and at some level irrational ideas. The paramount question facing anyone who wants to assert the possibility of utopian imagination becomes the identification of a space, an imaginable potentially utopian space, and a time, an imaginably potentially fruitful and productive time, to which citizens, residents of the present, have access or might yet gain entrée. This space and time forms an alternative to the extant or observable world. Some feel this space is widening in post-modern times, perhaps as a consequence of Derridean indefinite deferral of conclusiveness, of Foucauldian contention with respect to knowledge, or of the proliferation of interstitial subject positions. Perhaps they are right, and these developments are not superficial textual practices with restricted substantive impacts on material lives. ${ }^{59}$ If so, the widening of the possibilities for utopian thinking may be the gift post-modernity has given to the future. That gift, if it is a gift, has come in the wake of some losses for those who have had to live through post-modern times' deconstructive throes.

\section{The Subject of Utopia}

One of the most widely lamented casualties of these deconstructive moments, as well as one of their most celebrated victories in other camps, has been "the subject," with or without an index like Cartesian, humanistic, or centered. The subject, as it appears in contemporary literature, is a vague term with a wide scope; in a particular context,

59. See Huntington, Ecstatic Subjects. 
it might embrace anything from the Kantian transcendental subject of knowledge to the decentered postmodern individual. This "inherent ambiguity of the term goes some way to explaining its popularity and productivity."60 Its use in postmodern texts, however, almost inevitably excludes, or explicitly challenges, the self-centered, self-aware, rational and realistic subject of experience and autonomous agency portrayed in rationalist philosophy, modern novels and economics textbooks. ${ }^{61}$ One sense, of particular relevance to a motivated reading of texts, is that of the grammatical subject, the substantive that performs the action of the verb. A subject of this kind undergoes the experience of something, or bears the description of a predicate, discursively. This grammatical and discursive subject can imply distinct subject positions, which readers of texts may recognize, or with which they may identify. From this perspective, the subject of utopia - as if there might be only one such subject - would be the substantive, and by extension, really or in imagination, the actual site of the experience of utopia.

Considerations of the usage of "subject" in contemporary social theory typically ignore or bypass another possible sense of the term, one more familiar in the context of the humanities. "Subject" can be used as in the sense of "subject matter," the thematic aspect of human experience interpreted through the form and content of some work of

60. David Macey, The Penguin Dictionary of Critical Theory (London: Penguin Books, 2000) 368-369.

61. For an overview of positions related to the "death of the subject" in the social sciences and critical theory, and their implications for social theory, see Rosenau, ibid., 42-61; Steven Best and Douglas Kellner, Postmodern Theory: Critical Interrogations (New York: Guilford Press, 1991) 283-294. For one lengthy discussion of the development of understandings of subjectivity and their relationship to concrete social forms, incorporating a recognition of their utopian moment, see Fredric Jameson, The Political Unconscious: Narrative as a Socially Symbolic Act (Ithaca: Cornell University Press, 1981). 
art. ${ }^{62}$ This usage preserves an echo of the pre-modern philosophical understanding of the term as "substance," present in the world, and contrasted to the mental concept, or object, of that substance. The "subject of utopia" in this sense would designate utopia considered as something to discuss, to write about, or perhaps even to endeavor to construct.

In the study that follows, "the subject," whether of utopia or of something other than utopia, will most often refer to a soft-focus superimposition of the discursive subject on the remnants of the kind of substantives mentioned in connection with suffering, who are protected by committees on research involving human subjects, and who might from time to time read the kinds of texts being discussed here. It takes as given that these subjects are collaborative, autopoietic constructs of language and practice, who make themselves, and are made by one another, individually and collectively, through complex and ongoing practices. Whether these subjects have a chance of becoming subjects of utopia is one of the questions utopian discourse might be expected to address. How that question comes to be answered in these writers' utopian discourse is one of the questions of this dissertation. The question is whether utopia can be the object of conscious experience. In other words, can utopia have a subject, either in the sense of a consciousness that knows utopia as utopia, or in the looser sense of a human subject living a happy life.

\section{Utopian Discourse in the Theatre of the Humanities}

The extended reflection on utopian discourse presented in this text situates itself in the larger context of the western humanities. This is true in spite of the "post-humanist" tenor of some of this discourse.

62. See F. David Martin and Lee A. Jacobus, The Humanities Through the Arts, $6^{\text {th }}$ ed. (New York: McGraw-Hill, 2004) 35-36. 
In particular, the problems being addressed by these theorists

correspond to the anti- or post-humanistic tenor of the early $21^{\text {st }}$

century. This circumstance, along with the circumstance that the text

serves a utilitarian purpose with respect to the humanities, call for a

few words outlining the relationship of this reflection to the context

of the humanities.

The images of utopia that are the central object of reflection in

this text, including the abstract verbal ones that discourse creates,

have specific properties of interest from the perspective of a more

encompassing relationship to the humanities. In particular, these

images of an "impossible place" or a topos outopos, a place that is

nowhere, bring together considerations from different corners of the

humanistic field. In the arrangement of these themes displayed in

images of utopia, it is sometimes possible to discern underlying

structural similarities and relationships among these different areas.

As images, the images of utopia considered here immediately

participate in the realm of art, or aesthetics, understood as a system or systems of representation, in particular the representation of beauty. ${ }^{63}$ Some utopian images are, at least arguably, presented as images of beauty by their authors. Considerations relevant to the analysis and understanding of art, particularly literary art, are relevant to any reflection on utopian discourse as imagistic discourse constructing a representation of an idea. The notion that aesthetic criteria are inapplicable to a consideration of texts that have been

63. Bryan S. Turner, "Introduction," in Christine Buci-Glucksmann, Baroque Reason: The Aesthetics of Modernity, trans. Patrick Camiller (London: Sage Publications, 1994) 1-36; Albert Hofstadter and Richard Kuhns, "Introduction," in Albert Hofstadter and Richard Kuhns, eds., Philosophies of Art and Beauty: Selected Readings in Aesthetics From Plato to Heidegger (Chicago: University of Chicago Press, 1976) xiii-xix. 
categorized as philosophical is, moreover, challenged explicitly by each of these authors.

As images that include suffering as their subject matter, in the form of its negation, or in the temporalized form of its having-beennegated, this discourse demonstrates particularly clearly the transformation of material that takes place in the process of producing a particular aesthetic form. ${ }^{64}$ This transformation characterizes the working-out of the artistic idea in general. It is never foreign to the working-out of ideas in textual form, which can be presented generally as a poetic practice, whether or not the final form of the text can qualify as poetry in the strict sense. The image that is utopia, as an image of suffering transformed into happiness, constitutes an initial and significant effort to come to terms with suffering in the concrete, and to imagine its resolution. While this imaginative transformation remains partial, questionable, and abstract from the standpoint of discrete and concrete subjects of suffering, it is an indispensable moment of any actual artistry involving suffering.

Utopias, as images that present the form of the having-beenovercome of suffering, participate in an ancient artistic project, that of making real and present, or at least visible, discernible, and tangible, the highest good. ${ }^{65}$ These avowedly secular images of utopia then qualify as the descendents of early art produced in the service of

64. The recognition of the intrinsic content of suffering in art is one of the central holdings of Adorno's aesthetic theory. "All that art can do is to grieve for the sacrifice it makes and which it itself, in its powerlessness, is." Adorno, Aesthetic Theory, 52.

65. Georg Wilhelm Friedrich Hegel, "The Philosophy of Fine Art," trans. F.P.B. Osmaston, in Hofstadter and Kuhns, ibid., 378-445, 388; E.H. Gombrich, The Story of Art (London: Phaidon Press, 2006) 37-47; James Elkins, On the Strange Place of Religion in Contemporary Art (London: Routledge, 2004) 5-12. 
the sacred. Utopia qualifies as a secular treatment of a fundamentally religious aesthetic program. ${ }^{66}$

Because of the relationship of utopia, generally as image and specifically as image of the highest good, to the western tradition and in particular the Jewish tradition of aniconic monotheism, utopian images themselves skirt the frontiers of idolatry, on one hand, and of prophetic imagination and announcement on the other. The problem of discernment posed by the enunciation of discrepant prophetic messages, of how to know idolatrous false pronouncements as false and to know the true word emanating from the holy as true, bedevils utopian images as well, and poses problems for the assessment of these images. ${ }^{67}$ The problems associated with the discernment of the "rational" or "reasonable" character of utopian imaginings relates to this problem of warding off idolatry. However, the problem of making a fetish of certain forms of rationality, which revert to irrationality and barbarism, arises in the context of utopian images as well. ${ }^{68}$

The images that are utopias embody aspirations towards epiphany as part of their artistic concept. They have for their material the concrete substance of human life; they depict its transformation as a formal substitute for the alteration of that substance that is concretely desired. The images that are utopias are situated peculiarly at the conjunction of various modal (must, can, could, shall, should,

66. So the proximity of sacrifice to the aesthetic image, as referenced by Hullot-Kentor in his introduction to Kierkegaard: Construction of the Aesthetic, takes on a deeper significance. See Robert Hullot-Kentor, "Foreword: Critique of the organic," Theodor W. Adorno, Kierkegaard: Construction of the Aesthetic, trans. R. Hullot-Kentor (Minneapolis: University of Minnesota Press, 1989), x-xxiii.

67. A classic presentation of the problem in Biblical literature occurs in Jeremiah 27-29.

68. See Max Horkheimer and Theodor W. Adorno, Dialectic of Enlightenment: Philosophical Fragments, ed. Gunzelin Schmid Noerr, trans. Edmund Jephcott (Stanford: Stanford University Press, 2002) on the problem of rational irrationality, its roots in mythic religious impulses, and its relationship to the production of images and the reproduction of culture. 
might, will, would, imperative, subjunctive, positive, declarative, interrogatory), temporal (now, once, later, sometime, never, again) and spatial (here, there, elsewhere) possibilities for relating being, nonbeing, and becoming. The discussion of the relationship of being, nonbeing, and becoming constitutes the contemporary terminology of epiphany - the "sudden appearance of the divine" - as the authentic manifestation of presence or the alchemical transformation of base existence into something altogether finer.

Relevance of Utopia in the Late $20^{\text {th }}$ Century

It makes sense to focus on the work of late $20^{\text {th }}$ century figures because the late $20^{\text {th }}$ century period poses specific challenges for utopian discourse, on all fronts. The image character of utopian presentation becomes problematic. Whether a fundamentally metaphysical idea like utopia can continue to be advanced in a "post-metaphysical" age becomes questionable. The significance of the linguistic character of utopian representations makes utopian imagination increasingly vulnerable in an age in which the resistant quality of language and its always already constitutive character make everything done with and in language suspect. Ontological concerns call utopian imagination into question as a refuge of metaphysics. Nominalist nihilism and pseudopragmatic positivism foreclose more and more avenues of access to a plausible consciousness of potentiality. From the standpoint of the possible rehabilitation of utopian discourse and a possible innervation of pro-utopian praxis in the contemporary period, the discourse that grapples with these challenges is the discourse that requires understanding and comment.

\section{Reasons for the Choice of These Thinkers}

This project has come to revolve around the work of three particular late-20 th-century philosophers, Theodor W. Adorno, Luce 
Irigaray, and Giorgio Agamben. These three philosophers together form a satisfyingly complex and striking chord based on common key concerns and chromatic variations in philosophical lineage, methodological approach, and points of focus.

All are distinctly late modern or postmodern thinkers. This historical proximity is relevant for at least two reasons. They are acutely aware of the role of history in the formation of human consciousness and, beyond that, of the subconscious, the wellspring of desire. The idea that desire itself, the inner nature of the human person or individual human subject, is affected by history, both personal and social, is a given for these authors. Most moderns share this idea. It makes the discussion of utopian possibilities even more complicated than it already was for the early modern utopians, as already noted.

All are also sensitive to and interested in the role of language in the process of conceptualizing the object of desire. In this regard, Adorno, though sometimes identified as the quintessential high modernist, already points towards the "linguistic turn" that so pervasively haunts the postmodern age. All these thinkers accept that consciousness is shaped and given to us in and through language. All also affirm that there is something that nevertheless escapes the net of language. They each adopt the simple but vexing stance that language communicates, or arises for the possibility of communicating, something that differs from language that eludes representation within it. Their refusal to abdicate this position unites all these thinkers, and impels them to their ultimately utopian positions. All are committed to the position that there is something people are trying to do with language that relates to perceiving as well as to making the world. With due respect for the ways language itself creates the world in which its 
speakers and writers live, these thinkers refuse the position that what we have access to through ordinary language exhausts relevant reality. All would regard that quintessentially anti-utopian position as a form of collusion with fundamentally oppressive forces. All would agree that the human ability to imagine more desirable, even ideally desirable, alternatives to the present is - at least possibly and at times - a form of knowledge, as well as an indispensable condition of human freedom.

Perhaps predictably, all of these thinkers struggle with issues of essentialism, its possible and necessary limits and its possible and desirable retention. Paul Tillich has argued that a certain irreducible minimum of essentialism is a requirement for utopian thinking. ${ }^{69}$ These thinkers endeavor to locate the liberating core of essentialism that at the same time escapes the imprisonment of rigid necessity, that exhibits possibility. All three thinkers draw in complex ways on the Platonic notion of the ideas. All three thinkers engage with the ghost of Heidegger. ${ }^{70} \mathrm{All}$, as will become clear, devote significant energies to aesthetic themes. All their texts are marked by a use of religious imagery that might be surprising in the work of such resolutely secular thinkers.

All three thinkers confront the basic dilemma of how much to rely on human desire in formulating strategies for the desirable human world, and in thinking about what that world would be. More precisely, perhaps, all three struggle with how, precisely, to rely on desire. The project of the negation of suffering must rely on desire. Nevertheless, desire is known to be unreliable and potentially treacherous thanks to its

69. Paul Tillich, "The Political Meaning of Utopia," in Political Expectation (New York: Harper and Row, 1971) 137.

70. This project will approach this troublesome Heideggerian connection negatively - that is, by avoidance - whenever possible. 
historical and linguistic constitution. The degree to which and the ways in which it is unreliable are hidden. Moreover, every response to desire - reliance, suppression, repression, cultivation - has pitfalls. The critical question is how to proceed in a way that takes both dialectical moments, the one of the trust and the one of mistrust of desire, equally seriousiy. How might it be possible to desire something like utopia, and simultaneously to temper desire by various practices that also cannot simply be trusted? How, in other words, might it be possible to cultivate something like "wisdom" with respect to utopia?

These thinkers are primarily concerned with focal projects other than utopia: the theorization of the relationship of the epistemological subject and object, the systematic interrogation of the androcentrism of the western philosophical paradigm, elucidating the root of bio-power-politics in the very notion of political sovereignty. Nevertheless, their projects lead them into the territory of utopian reflections. These reflections disclose the problematics of possibility. Their efforts to resolve the difficulties associated with it, and in the course of this resolution, to establish some reason to believe that there might be hope for processes that could bring about a world that does not yet exist, in which certain pressing problems are resolved, engage all three thinkers in utopian discourse.

A critical comparison of Adorno, Agamben and Irigaray that focuses specifically on the utopian dimensions of their work also makes sense in the context of current scholarly interest on these thinkers. That each of these thinkers displays utopian features is well-known. That this utopian thinking crucially informs their projects is appreciated to differing degrees, but deserves to be more widely and deeply appreciated in each case. A comparison of these thinkers' approaches 
and insights in thinking about the possible human world does not yet exist, and could be of genuine interest to scholars concerned with the work of each of these thinkers individually, as well as to scholars interested more generally in contemporary thought in the areas of aesthetics and religion.

Adorno

Adorno invokes the category of utopia explicitly. Adorno's own utopian thought has not attracted the full attention it deserves, and has not become the subject of study in its own right. The relative neglect of Adorno's utopian thinking among utopians may be the consequence of a commensurate focus on other, more accessibly utopian, German thinkers by scholars of utopia: Marcuse, Adorno's fellow Frankfurt School theorist, was for many years more accessible to English-speaking readers, and posed a clearer case study in utopian thinking, while Ernst Bloch could hardly be ignored as the central and influential German Marxist theorist of utopia. ${ }^{71}$ In spite of Bloch's explicit and acknowledged influence on Adorno, and in spite of Adorno's own significant reflections on utopia and his nuanced and precise alternative to Marcuse, there has yet to be a dedicated focus on Adorno as a utopian thinker. ${ }^{72}$

Adorno's own rhetoric is sufficiently pessimistic that early readers identified him more as a dismal nay-sayer than a seeker after hope. This, indeed, was Gillian Rose's guiding thesis in her study of Adorno. For Rose, Adorno is driven to the study of philosophy not

71. Vincent Geoghegan, Utopianism and Marxism (London: Methuen, 1987); Ruth Levitas, ibid.

72. Adorno himself identified Bloch's Spirit of Utopia as a lasting influence on his own thought. See Susan Buck-Morss, The Origin of Negative Dialectics (New York: The Free Press, 1977) 4. Fredric Jameson's treatments of Adorno's utopianism occur as an element in the context of wider reflections on utopian thought, or in the context of the extended treatment of Adorno's late thought as a whole. Fredric Jameson, Late Marxism: Adorno or the Persistence of the Dialectic (London: Verso, 1990); Jameson, Archaeologies, 172-175. 
because it offers deep and abiding hope for the future of humankind in desperate times, but because it is the only possibility, and because Adorno is looking for something that has the promise of effectiveness, in spite of not finding it yet. ${ }^{73}$ This is the Adorno remembered for denying the possibility of poetry after Auschwitz.

But as the brilliant and dedicated Adorno scholar Lambert Zuidervaart points out, this admittedly prominent side of Adorno's social thought is not the only one. Zuidervaart cites rhetoric like Adorno's stirring paean to the folly of art in the closing metaphysical meditations of Negative Dialectics and insists that "[i]f the ongoing assessment of Adorno's social philosophy does not address such passages, it will not truly have begun."74 Zuidervaart's wide-ranging and comprehensive work, in fact, organizes central currents in recent Adornian scholarship, from Menke's efforts to read Adorno's aesthetics through the frame of Derridean deconstruction, through the gathering critiques of Adorno's views on popular culture and the limits on his wholesale dismissal of popular culture as oppressive, to a consideration of Adorno's relationship to Heidegger on one hand and Habermas on the other. ${ }^{75}$ Most central for a consideration of Adorno as a utopian thinker, however, is Zuidervaart's assessment of the efforts to read Adorno as a postmetaphysical thinker and to recontextualize his metaphysics as a dialectic of suffering and hope, as well as his lengthy and (it must be suspected) theologically-motivated critique of

73. Gillian Rose, The Melancholy Science: An Introduction to the Thought of Theodor W. Adorno (New York: Macmillan, 1978).

74. Lambert Zuidervaart, Social Philosophy After Adorno (Cambridge: Cambridge University Press, 2007) 201. Zuidervaart cites Adorno's statement that "Folly is truth in the shape that human beings must accept whenever, amid the untrue, they do not give up truth" (Negative Dialectics 404, as translated by Zuidervaart)

75. Eor the discussion of Derrida, see Christopher Menke, The Sovereignty of Art: Aesthetic Negativity in Adorno and Derrida, trans. Neil Solomon (Cambridge, MA: MIT Press, 1998); Zuidervaart, ibid. 
Adorno's success in combining these elements in a philosophical

treatment of the late $20^{\text {th }}$-century situation. ${ }^{76}$

Zuidervaart's implicitly theological critique of Adorno's

metaphysics points to another aspect of contemporary scholarly

treatment of Adorno, which is less explicit in Zuidervaart, namely, the identification of religious themes in Adorno's work, and the difficulty of treating these themes. Brian $O^{\prime}$ Connor notes those, and is at pains to distinguish between religious rhetoric and religious commitment in Adorno's work. He notes that Adorno's use of religious thematics is made more possible by his strictly secular philosophical commitments. ${ }^{77}$ Hent de Vries somewhat similarly identifies Adorno as approaching the limits, in the context of a secular philosophy, of the boundaries of subject-object experience, which drives his philosophy in a theological direction. ${ }^{78}$

This latent and troublesome religious dimension in Adorno's work has been noted before, in particular by Susan Buck-Morss in her early work on Adorno's Negative Dialectic. There Buck-Morss traces the influence of the "early Benjamin," which "incorporated structural elements from such seemingly remote sources as Jewish mysticism, Kantianism, Platonism, and German Romanticism," on Adorno's mature

76. Zuidervaart, ibid., 48-76. Zuidervaart identifies one difficulty with Adorno's thought as his provision of a strictly "negative utopia." In this he echoes his contemporary critics as well, notably siegfried Kracauer, who faulted him for inadequately utopian thinking. See Lorenz Jager, Adorno: A Political Biography, trans. Stewart Spencer (New Haven: Yale University Press, 2004).

77. Brian O'Connor, Adorno's Negative Dialectic: Philosophy and the Possibility of Critical Rationality (Cambridge, MA: The MIT Press, 2004), see especially 165-173.

78. Hent de Vries, Minimal Theologies: Critiques of Secular Reason in Adorno \& Levinas trans. Geoffrey Hale (Baltimore: The Johns Hopkins University Press, 2005). For de Vries, this imperative is similarly evident in the thought of Levinas, working with the same fundamental philosophical problem within a different philosophical framework, phenemenology vs. dialectics. 
masterwork. ${ }^{79}$ Martin Jay, however, goes further and attributes a direct influence of rabbinical Judaism on Adorno's later philosophy. ${ }^{80}$ From the standpoint of a consideration of the utopian dimensions of Adorno's thought, in particular, this element of his thinking becomes significant, as utopian theory itself is significantly thematized, at least in western European culture, through the symbols and texts of Judaism and Christianity, the thematics of the world to come and the City of God. ${ }^{81}$

More recently, a resurgence of interest in Adorno has focused most intently on his aesthetics and his social thought. O'Connor, one of the leading lights in this resurgence, attributes it to the new availability of more reliable texts in translation, which has led a rise in the popular reception of Adorno's work in the American academy. O'Connor stresses the transcendental form of Adorno's philosophy, and makes much of his affinities with, and at the same time, highly specific differences from, Heidegger. ${ }^{82} \mathrm{O}^{\prime}$ Connor's analysis presents Adorno as addressing the same central philosophical problem as Heidegger - that of the structure of experience - from the epistemological rather than the fundamental ontological side. O'Connor shares Adorno's conviction that the epistemological approach succeeds, in the end, where Heidegger's ontological approach fails. ${ }^{83}$ This conclusion is significant for an assessment of Adorno's utopian

79. Buck-Morss, ibid., xiii; see also S. Brent Plate, Walter Benjamin, Religion, and Aesthetic: Rethinking Religion Through the Arts (New York: Routledge, 2005), who attributes Adorno's "monadic" concept of the work of art to Benjamin's theologically-influenced aesthetics.

80. Martin Jay, Adorno (Cambridge, MA: Harvard University Press, 1984).

81. Dorothy F. Donnelly, Patterns of Order and Utopia (New York: St. Martin's Press, 1998).

82. O'Connor, ibid.

83. This analysis, if correct, points to one possible source of the tensions between Adorno and his erstwhile professor Paul Tillich, with whom he nevertheless shares some significant insights and commitments, in particular views about the centrality of the category of expectation and the role of "the critique of idolatry." 
discourse, because it suggests that Adorno's utopian thought must be understood as pointing towards praxological, world-transformative activity oriented towards arriving at understanding, rather than under the rubric of a different mode of being.

Adorno's aesthetics is another area in which his utopian leanings are widely seen, but less widely analyzed. Robert Hullot-Kentor in particular notes the utopian contour of Adorno's thought in Aesthetic Theory, and links it to Adorno's sense of a clear value ordering with respect to aesthetic works. According to Hullot-Kentor, Adorno's vision of aesthetic order gives us permission and motivation to ". . act on the impulse to protect ourselves, or our imagination anyway, as the power over possibility, from what otherwise uses that power, second by second almost, to break in on us and to defeat that possibility." 84

\section{Agamben}

The works of Giorgio Agamben, an Italian thinker, have only relatively recently emerged in English. Scholarly commentaries in English on Agamben's work are scarce, and those that exist outside the periodical literature deal primarily with his later political works, like Homo Sacer, rather than his earlier works on aesthetics. ${ }^{85}$ It is clear nevertheless that Agamben's work struggles with the same themes as Adorno's: the nature of the relationship between subject and object; the possibilities for metaphysical thinking in an allegedly postmetaphysical era; the aesthetic and theological legacies of Benjamin

84. Robert Hullot-Kentor, "Right Listening and a New Type of Human Being," in the Cambridge Companion to Adorno, ed. Tom Huhn (Cambridge: Cambridge University Press, 2004), 181-197, 196.

85. See Andrew Norris ed., Politics, Metaphysics, and Death: Essays on Giorgio Agamben's Homo Sacer (Durham and London: Duke University Press, 2005); Matthew Calarco and Steven DeCaroli, eds., Giorgio Agamben: Sovereignty and Life (Stanford: Stanford University Press, 2007); Thomas Carl Wall, Radical Passivity: Levinas, Blanchot, and Agamben (Albany: SUNY Press, 1999). The first dedicated treatment of Agamben's aesthetics in English is William Watkin, The Literary Agamben: Adventures in Logopoiesis (New York: Continuum, 2010). 
and Heidegger; the possibility of a just politics; the contribution of artists and thinkers to the pursuit of that politics. Adorno's position vis-à-vis the linguistic turn might be questioned; Agamben's cannot be. Agamben's project centers on the identification of philosophy, at least since Plato, with the struggle to comprehend the elusive matter of the unnamable creative possibility that seems to lie just back of or within what goes by the name of language. ${ }^{86}$ The comparison of Adorno's and Agamben's modernist and decidedly postmodernist approaches to the conceptualization of a possible world promises to be illuminating. Commentators who have approached Agamben's work have generally ignored its utopian dimensions. His treatment of sovereignty, and his approach to passivity, have so far attracted most attention. This is remarkable, however. In The Coming Community Agamben points to possibilities for transformation of the political realm; that he is attempting to work out an understanding of these possibilities that preserves the diversity of their singular human subjects seems beyond question. ${ }^{87}$ Similarly, the persistent religious dimension of his thought, from his treatment of Pauline messianism in The Time That Remains to his invocation of Talmudic and Trinitarian thematics in the Coming Community, failed to generate immediate comment. This is in spite of a growing recognition of the phenomenon of "post-secular" thought, to which Agamben clearly contributes. ${ }^{88}$ An explication of Agamben's utopian thinking, which proceeds in a profoundly negative and "iconoclastic" way, is long overdue.

86. Giorgio Agamben, Potentialities, trans. Daniel Heller-Roazen (Stanford: Stanford University Press, 1999), in particular "The Thing Itself," 27-38 and "The Idea of Language," 39-47.

87. Agamben, The Coming Community.

88. Giorgio Agamben, The Time That Remains: A Commentary on the Letter to the Romans, trans. Patricia Dailey (Stanford: Stanford University Press, 2005); Philip Blond ed., Post-Secular Philosophy: Between Philosophy and Theology (London and New York: Routledge, 1998). 
Irigaray

Neither Adorno nor Agamben devote sufficient attention to gender. If for no other reason than the fundamental inadequacy of a consideration of utopia, the horizon of human possibility, that fails to consider the role of gender, it would be necessary to raise the issue of gender vis-à-vis these thinkers. Beyond that consideration, however, the work of Luce Irigaray bears significantly and prolifically on precisely the matters being considered by both Adorno and Agamben in their different registers: the constitution of the subject, the subject-object relationship, and the implications of the structure of that experience for human knowledge - both of what is, and of what might be or become; the role of language as the mediation of this experience; and the possibilities for the reality, or realization, of a better world of human experience. Significantly, Irigaray is explicit in her inclusion of corporeality and desire in her work. Both of these dimensions are unavoidable in the work of Adorno and Agamben as well. According to at least one reader, the consequences of this inclusion are far-reaching. "Woman becomes visible in her absence, disrupting and instigating the rereading of the whole discursive history of subjectivity."89 That would seem to make Irigaray required reading for scholars interested in the utopian dimensions of thinking about the relationship of subject and object.

Scholars repeatedly note Irigaray's utopianism. ${ }^{90}$ Huntington, in particular, draws on Irigaray specifically as a utopian thinker, with a

89. Simon Patrick Walter, "Situating Irigaray," in Philosophy and Desire, ed. Hugh J. Silverman (London: Routledge, 2000), 111-124, 111.

90. See Whitford, ibid.; Drucilla Cornell, Beyond Accommodation: Ethical Feminism, Deconstruction, and the Law (New York: Routledge, 1991); Patricia J. Huntington, Ecstatic Subjects; Ewa Plonowska Ziarek, An Ethics of Dissensus: Postmodernity, Feminism, and the Politics of Radical Democracy (Stanford: Stanford University Press, 2001); Rachel Alsop, Annette Fitzsimmons, Kathleen Lennon and Rosalind Minsky, Theorizing Gender (Cambridge: Polity Press, 2002); 
significant debt to Heidegger, and argues that Irigaray "repeats . . . two Heideggerian mistakes in attentuated form," namely, a lack of a dialectical approach and a perpetuation of a model of transgression as a "negation of what is."91 If she is correct, there is much to be gained by setting Irigaray into dialogue with Adorno in particular.

Like Adorno and Agamben, Irigaray draws on religious and theological resources in her work, famously so; unlike them, she celebrates the possibilities of re-conceptualizing the divine "in the feminine gender" as an explicit dimension of her pro-utopian project. ${ }^{92}$ In so doing, Irigaray makes explicit the religious implications and involvements of utopian discourse. The religious dimensions of Irigaray's work are, again, commonplaces. Nevertheless, a sustained consideration of the relationship of her religious thought to the utopian content of her philosophy seems not to have been undertaken by scholars, who seem more likely to be interested either in Irigaray's possible relevance for secular politics, or for Irigaray's relationship to feminist theology, but not the relationship between the two.

Critiques of Irigaray as essentialist and clandestinely heteronormative may require tempering. ${ }^{93}$ More appreciative readers perceive Irigaray as pragmatically utopian and strategically hyperbolic in her extravagant claims about feminine jouissance. ${ }^{94}$ Tina Chanter and

Gary Gutting, French Philosophy in the Twentieth Century (Cambridge: Cambridge University Press, 2001).

91. Huntington, ibid., $\mathrm{xxx}$.

92. Serene Jones, "Divining Women: Irigaray and Feminist Theologians," Yale French Studies 87 (1995) 42-67; Alison Ainley, "Luce Irigaray: Divine Spirit and Feminine Space," in Post-Secular Philosophy: Between philosophy and theology, ed. Phillip Blond (London: Routledge, 1998) 334-345; Morny Joy, Kathleen $O^{\prime}$ Grady and Judith $I$. Poxon, French Feminists on Religion: A Reader (London and New York: Routledge, 2002).

93. Alsop et al., Theorizing Gender; Judith Butler, Gender Trouble: Feminism and the Subversion of Identity (New York: Routledge, 1999).

94. Cornell, Beyond Accommodation; Pheng Cheah, Elizabeth Grosz, Judith Butler, Drucilla Cornell, "The Future of Sexual Difference: An Interview with Judith Butler and Drucilla Cornell," Diacritics 28:1 (Spring, 1998) 19-42; 
Margaret Whitford, from different angles, insist that Irigaray's fabled essentialism is more apparent than real, an artifact of literalist misreading on the part of her second wave feminist critics. ${ }^{95}$ More recently, Penelope Deutscher has extended this line of reading to a consideration of Irigaray's implications for multiculturalism, and the politics of diversity, concluding that Irigaray's project involves the effort to rethink egalitarian politics from the standpoint of differences rather than sameness. ${ }^{96} \mathrm{~A}$ critical comparison of utopian discourse seems precisely the context in which to examine these claims and possibilities.

As noted, there is arguably an irreducibly essentialist element to any utopian thinking, which may speak to the purpose behind Irigaray's apparent essentialism in treating sexual difference. ${ }^{97}$ Nevertheless, it is perilously possible to misspecify the human essence that underwrites the arguable rationality of utopian thought. The perennial discourse about the possibility of man's [sic] pursuit of the good life vividly demonstrates the peril. Irigaray's frankly provocative work centering on the philosophical, linguistic, poietic, religious, and political implications of sexual difference counterbalances the neglect of gender in the work of Adorno and Agamben. ${ }^{98}$ In short, the possibilities for insight that emerge in bringing these deeply related and strategically

Dorothy Leland, "Irigaray's Discourse on Feminine Desire: Literalist and Strategic Readings," in Philosophy and Desire, Hugh J. Silverman, ed. (New York: Routledge, 2000), 125-139; Alison Stone, "The Sex of Nature: A Reinterpretation of Irigaray's Metaphysics and Political Thought," Hypatia 18:3 (Autumn, 2003) 60-84.

95. Whitford, ibid.; Tina Chanter, Ethics of Eros: Irigaray's Rewriting of the Philosophers (New York and London: Routledge, 1995).

96. Deutscher, ibid.

97. Tillich, ibid.

98. Gender is admittedly not the same category as sexual difference, and the conflation of the two here is a dangerous - but at least partially alert convenience. See Alsop et al, Theorizing Gender; Rosi Braidotti, Nomadic Subjects (New York: Columbia University Press, 1994). 
different thinkers together, focused on the practically as well as theoretically important horizon of utopia, are promising.

\section{Transcendence}

Many of the discursive themes shared by these thinkers, including those of utopia, religion, and art, are connected to one another by their relationship to the idea of transcendence. In particular, these themes touch on the question of whether and to what extent transcendence or something like it is possible and intelligible. The idea that people can know of and desire something that truly and irreducibly arises in some meaningful sense "from elsewhere" or "from outside" the world of everyday existence surfaces repeatedly in religious consciousness, in artistic endeavor, and in the utopian imagination. The same idea in its various guises plays a vital role for these thinkers.

We might say that each thinker's work explores the question of how to draw the mental map of a post-metaphysical epoch in such a way that it could still include utopia. ${ }^{99}$ Each of these thinkers, moreover, locates a similar method for this mapping, appropriate to a revised understanding of transcendence. This understanding takes shape in the course of an exploration of the uncharted territory of the concrete, material aspect of transcendence, impelled by an insistence that a space for something like transcendence must be held open, as the space of a possible "redemption" (Adorno), "outside" (Agamben), or creativity (Irigaray). In effect, these thinkers focus on re-thinking the central

99. An apparent generic requirement for texts dealing with utopia is the citation of Oscar Wilde's aphorism, penned in 1891, "A map of the world that does not include Utopia is not even worth glancing at," with or without the rest of the sentence: ". . . for it leaves out the one country at which Humanity is always landing. And when Humanity lands there, it looks out, and seeing a better country, sets sail. Progress is the realisation of Utopias." Oscar Wilde, "The Soul of Man Under Socialism," in The Soul of Man Under Socialism and Selected Critical Prose (London: Penguin Classics, 2001) 141. 
relationship of transcendence to immanence that structures the legacy of western metaphysics. ${ }^{100}$

Utopian discourse takes place, in this context, as a special form of the much older discourse on transcendence, being practiced under new terms and on new terrain, but with similar imperatives and impediments. As a result, it is subject to similar limitations. One of these is the requirement that whatever discourse advances as descriptions of the ideal not prevent a subsequent recognition of that ideal in radically unanticipated concrete forms. Jacoby's insight into the "iconoclastic" utopian tradition informed by messianic thought is relevant here.

The prohibition on images or Bilderverbot does not address the full complexity of the situation facing this utopian discourse, however. Another element of the complex problem of representation is the problem of exclusion, as a linguistic and philosophical problem that is also a looming pragmatic ethical and political problem. Human life that relates to what differs from it by exclusion poses an ever-present threat to life generally. For Adorno and for Agamben, both of whom situate themselves explicitly as "post-Auschwitz" thinkers, this everpresent threat of exclusion is symbolized acutely by Nazi anti-Semitic totalitarianism and its lethal exclusion of the Jews. In Irigaray, what is excluded constantly takes the as-yet-unrealized form of Woman, or women-as-subjects; that exclusion, too, has lethal consequences, not alone for Woman but for Humanity and Life. The problem of exclusion, as well as of desire, connects by-now familiar conceptual outposts: the subject and the subject's relation to its object or objects; nature and its relationship to culture; language; death; time; space.

100. For one discussion of the relationship of transcendence to immanence in western metaphysics, see Noëlle Vahanian, Language, Desire, and Theology (London: Routledge, 2003). 
The philosophical representation of the idea "utopia" names poses a difficult and delicate task. The utopian image is not only prohibited, it is necessary, ineluctable, and impossible. A simple non-dialectical avoidance of representation will not suffice, even if it could be sustained, which it cannot be. The feat to be performed includes the ineluctable discursive representation, its critical self-awareness as representation, its self-limitation or discipline as necessarily partial and erroneous, and its self-assertion, both as forthright critique of a dystopian and ideological context which effectively nullifies such critical representations, and as perspicuous insight into the situation's need and potential for change. The feat required is more precise and more challenging than Adorno's remark that the contemporary philosopher "must know how to wish."101 It is like the tasks assigned to the protagonists of fairy-tales, who must find the land between sea and shore, for instance, or come to the trial neither by night nor by day. In the case of utopian thought, the task is to understand the relationship of the inconceivable subject of utopian happiness to the unimaginable object of utopian longing.

\section{The Matter of Messianic Light}

Theodor W. Adorno, in the conclusion to his exilic work Minima Moralia, links an evocative image to the problem of utopian representation:

The only philosophy which can be responsibly practised [sic] in face of despair is the attempt to contemplate all things as they would present themselves from the standpoint of redemption. Knowledge has no light but that shed on the world by redemption: all else is reconstruction, mere technique. Perspectives must be fashioned that displace and estrange the world, reveal it to be, with its rifts and crevices, as indigent and distorted as it will appear one day in the messianic light. ${ }^{102}$

101. Adorno, Negative Dialectics, 407.

102. Adorno, Minima Moralia, 247. 
Adorno's "messianic" language here does not indicate his anticipation of a concrete liberator, whether the Messiah awaited by pious Jews, Christians or Shi'ite Muslims, or the figure who, in the theologicalpolitical words of a young Walter Benjamin, alone "consummates all history, in the sense that he alone redeems, completes, creates its relation to the Messianic."103 For Adorno, the concrete question of whether that Messiah will one day arrive to usher in the redeemed world is explicitly beside the point. The possibility that matters is that of thinking what would be thought under the banner of the messianic. ${ }^{104}$

That banner has an unabashed metaphysical provenance. A Messiah or messiah can simply denote a liberator, particularly in the context of a national political struggle. The term "messianic" may even be extended to anyone or anything that effects a partial liberation or long-awaited reform. That looser, extended use of messianic language, however, owes its utility to the original development of the messianic idea within the context of religious tradition. The sacred narratives and popular elaborations, divine figures and interventions, and the expectation of supernatural blessings, reversals of injustice, and restoration of loss and damage that govern the strict usage of the term continue to color its metaphorical use. Metaphorical Messiahs and loosely messianic events may no longer have anything to do with anyone's God, and may or may not accomplish the end of human history. They do, however, continue to have something to do with liberation, with the end of injustice and

103. Walter Benjamin, "Theologico-Political Fragment" cited in Jacob Taubes, The Political Theology of Paul, trans. Dana Hollander (Stanford: Stanford University Press, 2004) 70. Taubes goes on to emphasize the distance between Benjamin's early, earnest treatment of "the Messiah" and Adorno's standpoint in the passage from Minima Moralia, which Taubes identifies with German Idealist aestheticism.

104. "But beside the demand thus placed on thought, the question of the reality or unreality of redemption itself hardly matters." Adorno, Minima Moralia, 247. 
the achievement of happiness and peace, and with the perfection of the world in which people find themselves living together as members of a single community. Moreover, just as the faithful of whatever religious tradition expected the Messiah to come from the neighborhood of the divine, the weaker modern "messianic" still seems to bring its new age from somewhere outside the closed system of this one. Messianic light retains a tinge of something metaphysical.

Even loosely messianic expectation is an expectation of something new, something strictly speaking unexpected. Penelope Deutscher, in The Politics of Impossible Difference, discusses the contradiction involved in this expectation. On one hand, people know what to expect when they expect liberation or a better world. On the other, because what they are awaiting is something new, they cannot possibly know what to expect. Even when people have an idea of something like the results they hope to enjoy, an idea of the injustices they hope no longer to see, and so forth, even then they cannot have a perfectly clear and distinct idea of what is to be expected from radical change. This contradiction is what makes the situation of messianic expectation "impossible" in Deutscher's terms. It also differs, in her analysis, from what she distinguishes as "messianism," a political movement that identifies the messiah with a particular figure or program. Such messianism, according to Deutscher, instead of acknowledging its own impossibility, disavows it. That disavowal makes messianism dangerous, in a way that selfconsciously impossible messianic expectation is not. ${ }^{105}$

Deutscher's analysis of the messianic parallels Fredric Jameson's assessment of the impossibility of utopian expectation in Archaeologies of the Future. Utopian imagination, too, faces the specific

105. Deutscher, ibid., 105. 
impossibility associated with the inability to imagine something that would amount to fundamental change. The more fundamental and complete the difference between the current situation and its utopian alternative, the less accessible that alternative becomes to imagination and contemplation. In fact, there is a chance that the present contemplating a utopian future, or the immediate context contemplating an alternative utopian location, cannot identify genuinely beneficial alternatives as pleasant or desirable. The predicaments facing messianic expectation and utopian imagination parallel one another.

The parallel may help explain the deep affinity between these two strains of thought, which historically and culturally have sometimes coincided powerfully. Ample evidence supports the historical link between more traditional messianic expectation and utopian theories and programs, particularly in $19^{\text {th }}$ century Europe. ${ }^{106}$ The utopian discourse of these three late $20^{\text {th }}$ century philosophers is another occasion in which messianic language expresses utopian themes.

Adorno is not the only one of this trio of thinkers whose thought sometimes takes up messianic language. Agamben engages with the language of the messianic explicitly and extensively, as for instance in his search for the possibility of "something like a messianic community" in his analysis of the Epistle to the Romans. ${ }^{107}$ Durantaye calls Agamben's enigmatic treatment of the "messianic" the central idea of Agamben's philosophy of potentiality. ${ }^{108}$ While Irigaray does not invoke "the messianic" explicitly, her readers repeatedly spot messianic themes in her work. Penelope Deutscher, for instance, invokes

106. Michael Löwy, Redemption and Utopia: Libertarian Judaism in Central Europe, trans. Hope Heany (Stanford: Stanford University Press, 1992).

107. Agamben, Time That Remains, 2.

108. Durantaye, ibid., 366. 
the notion of "the messianic" in her analysis of Irigaray's politics, while Margaret Whitford sees a "'messianic' Coming" along with other terms drawn from the language of religion coding her call for a "new era" in An Ethics of Sexual Difference. ${ }^{109}$

The loosening of messianic usage, and the parallels apparent between this looser usage and the classic dilemmas of utopianism, encourage the effort to treat this link between messianic and utopian discourse seriously. The language of "messianic light" not only resonates with the thinking of each of these thinkers, it incorporates common themes that bring their individual contributions to utopian discourse into conversation with one another. Aside from the longstanding connection of messianic themes and utopian discourse, and aside from the privileged use of light as a metaphor for understanding, questionable as that usage is, "messianic light" has additional interesting properties. It is matter; it captures the material emphasis these thinkers share. It is subjective; it retains a connotation of an agent of the anticipated change. It is imagistic, but its image is, paradoxically, absent.

The messianic light Adorno invokes is a figure for the object of desire that animates the philosophy, and philosophers, whose despair would be that of meeting the demands imposed by late modern and postmodern dystopia. It is light that reaches a suffering world and its suffering inhabitants from an impossible place and time: from some place outside the world that is, from a time that permits entry from the present without being determined by its past. The continuing question before this study of utopian discourse is how the metaphor of

109. Deutscher, ibid., 106; Margaret Whitford, "Irigaray, Utopia and the Death Drive," in Engaging with Irigaray: Eeminist Philosophy and Modern European Thought, eds. Carolyn Burke, Naomi Schor, and Margaret Whitford (New York: Columbia University Press, 1994) 379-399, 385. 
messianic light relates to the idea of utopia being discussed along the way of these writers' works.

\section{Plan of the Work and Key Issues}

Towards that end, the text develops along the following lines. Chapters two, three and four devote extended consideration to each of the thinkers under consideration. Chapter two focuses on Adorno's utopian discourse, with particular emphasis on his commitment to an unfolding of dialectical method, as well as consideration of his advocacy of "micrology" as a method. Chapter three turns to Irigaray's utopian discourse, with particular emphasis on her later work, which focuses on the requirements and processes of dyadic interaction and the cultivation of relationship between differing subjectivities, expressed as relations of sexual difference. Chapter four then treats Agamben's utopian discourse, with particular emphasis on Agamben's concept of messianic time and his championship of Benjamin's concept of the "dialectic at a standstill."

Each of these chapters treats a restricted number of key thematic issues according to a single pattern of organization, which facilitates a final critical comparison of the different discourses. The discussion opens with a consideration of the specific dystopian vision that informs the author's overall project, and that vision's demand for a revision of basic concepts and a use of novel textual form. This discussion of dystopian vision and basic response contextualizes a review of the author's overall project, and prepares for a more detailed discussion of the treatment of utopia within it. The discussion then turns to a more pointed examination of the author's engagement with three common and structurally key issues. These are: the critique of language in relation to the reader as subject; the treatment of the subject-object problem in relation to the problem of 
domination and the subject's potential for transformative action; and the representation of space and time in relation to the promise of utopia.

Chapter five then does two things by way of conclusion. First, it spells out the critical comparisons that emerge from the discussion of each author's utopian discourse. This comparative exercise demonstrates that Adorno, Irigaray and Agamben share a discursive structure that incorporates prophetic elements along with elements more typical of philosophical truth-telling. ${ }^{110}$ This discourse addresses itself to a "subject of utopian possibility" that is an available and transformative response to their texts. Utopian discourse of this form works to call into action a "subject of utopian possibility" that can undertake the ongoing task of utopian imagination and perhaps even utopian striving. The comparative focus then shifts to a consideration of the significance of this common structure as a form of utopian discourse. That discussion concludes that the prophetic elements of this discourse are not merely incidental to the utopian project; they emerge from these authors' effort to propose a source of metaphysical experience that is both adequate to and tenable in a radically postmetaphysical context. Their refusal of other key elements of prophetic discourse, in particular the element of utopian representation, functions to potentiate this metaphysical content, as it works to block the potentially toxic effects of metaphysical images.

110. This argument draws to an extent on Michel Foucault's typology of "modes of veridiction" in the ancient world. See Michel Foucault, Le courage de la vérité: Le gouvernement de soi et des autres II: Cours au Collège de France (1983-1984), ed. Frédéric Gros, A. Gallimard (Paris: Seuil, 2009) and Michel Foucault, Fearless Speech, ed. Joseph Pearson (Los Angeles: Semiotext (e), 2001$).$ 
CHAPTER II

REFLECTION

Theodor $W$. Adorno is best known as a significant, perhaps the most significant, theorist of the Frankfurt School. Between 1920 and his death in 1969 he authored works spanning metaphysical meditations to musicology, which run to 20 volumes of collected writings. Overshadowed in the US in the 1960 s by his more accessible colleague Herbert Marcuse, the reception of his works hampered by inadequate translations, Adorno also became known for being a "mandarin aesthete" with an apolitically intellectual approach to critical theory and a bleak outlook. ${ }^{1}$ More recently, his early and careful discussions of the materiality of language and his critique of phenomenology have intrigued students of post-structuralism and deconstruction, and Fredric Jameson has dubbed his particular brand of Marxism perhaps "just what we need today."2 Despite his well-earned reputation as a pessimist, Adorno also qualifies as a significantly utopian thinker. His thought takes especially seriously the pressing need to locate and theorize the intellectual prerequisites for utopian consciousness. Russell Jacoby portrays Adorno's approach as emblematic of the "iconoclastic utopian"

1. See Henry W. Pickford, "Preface," in Theodor W. Adorno, Critical Models: Interventions and Catchwords, translated by Henry w. Pickford (New York: Columbia University Press, 1998) vii-xii; Martin Jay, "Adorno in America," New German Critique No. 31 (Winter, 1984) 157-182.

2. Fredric Jameson, Late Marxism: Adorno or the Persistence of the Dialectic (London: Verso, 2007), first published 1990. See also Jay, ibid.; de Vries, ibid. 
thought he champions. ${ }^{3}$ Moreover, Adorno's utopian thought remains tenaciously though minimally, hopeful. Lambert zuidervaart notes that Adorno's "own alternative to both traditional metaphysics and more recent antimetaphysics" achieves expression "in passages that juxtapose resolute self-criticism and impassioned hope," and insists that if "the ongoing assessment of Adorno's philosophy does not address such passages, it will not truly have begun."4 That assessment speaks to the depth of the utopian element discernible in Adorno's work.

Adorno's explicit references to utopia are limited in number, but revealing. Adorno's well-known rejection of systems, "totality," and positive philosophical resolutions stems from his determination to safeguard the horizon of possibility required by utopian imagination; his overall project appears from that standpoint to have this object consistently in view. His work persistently traces the requirements of a tenable and truthful thought capable of understanding and articulating that possibility. The truth in the characterization of Adorno as a pessimistic thinker is his uncompromising delineation of the stringency of those requirements. The philosopher who said that "metaphysics must know how to wish" explicitly disdained wishful thinking; his self-appointed task was to see whether, and how, rigorous thought might arrive at or near the conclusions demanded by the "need in thinking." 5

This task is made at once "the simplest of all things" and "the utterly impossible thing" by the problematic possibility of reflection. In his conclusion to Minima Moralia, Adorno insists that the perspective sought by thought from "messianic light" ought already to

3. Jacoby, ibid.

4. Lambert Zuidervaart, "Theodor W. Adorno," Stanford Encyclopedia of Philosophy, http://plato.stanford.edu/entries/adorno, (accessed August 3, 2007). 5. Adorno, Negative Dialectics, 407-408. 
be available in the present as if by a simple kind of reflection, ". . . because consummate negativity, once squarely faced, delineates the mirror image of its opposite." ${ }^{6}$ Unfortunately, making use of that reflection

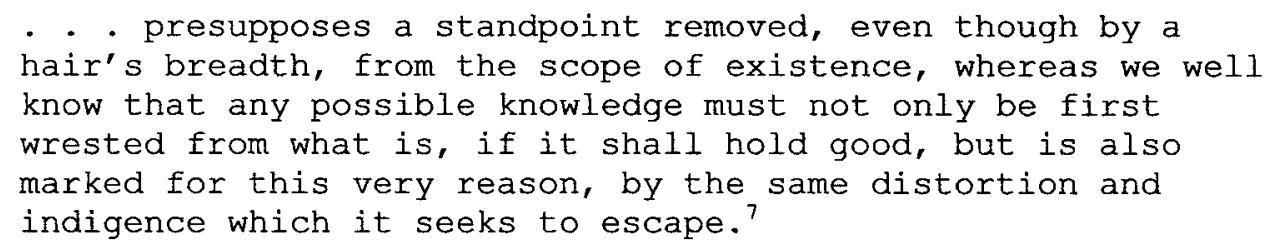

Thus, while "[n]० light falls on men and things without reflecting transcendence," the problem with that indispensable and promising knowledge is that along with transcendence it reflects the glare of an inextricable involvement. ${ }^{8}$ The self-same reflection of transcendence that sheds light also blinds "the eye that does not want the colors of the world to fade" to their source in something different from the known world. "The inextinguishable color comes from non-being." 9 Thought - the reflection that might yet understand this - will only serve this source of transcendence when it takes its own distance, and its own ultimate inadequacy, seriously.

The more passionately thought denies its conditionality for the sake of the unconditional, the more unconsciously, and so calamitously, it is delivered up to the world. Even its own impossibility it must at last comprehend for the sake of the possible. ${ }^{10}$

Thus, Adorno is no utopian thinker, but his thought turns persistently towards utopia; ignoring his utopian aspirations distorts his work. Presenting this side of Adorno's thought, and drawing out its implications for contemporary utopian discourse, is the aim of this chapter.

\footnotetext{
6. Adorno, Minima Moralia, 247.

7. Ibid.

8. Adorno, Negative Dialectics, 404 .

9. Ibid., 57 .

10. Adorno, Minima Moralia, 247.
} 
The discussion of Adorno that follows first reviews the dystopian perceptions catalogued in Adorno's work. Next, there is a brief review of the direction of his overall philosophical aims. This context serves as background for the detailed consideration of the appearance and place of utopian themes in that work. From this examination, the following sections look at Adorno's commitment to conceptual work, the role of textual form in its execution, his treatment of the subjectobject problem, its relationship to his critique of language, and finally his incorporation of space and time as arenas for the operation of the subject.

\section{The Universal Guilt Context}

Adorno may not regard the world as radically evil, as has been claimed. ${ }^{11}$ His work certainly depicts the world as characterized by a relentlessly oppressive and totalizing, socially created reality that operates to suppress even imaginative resistance to it, let alone direct active resistance. This suppression occurs before consciousness even registers the possibility of such resistance. All of Adorno's work attests to his perception of the radically undesirable and dangerous quality of this increasingly ubiquitous reality. Its classic formulation, however, is to be found in Dialectic of Enlightenment, a collaboration with Max Horkheimer, and a work roughly contemporaneous with the more personal, and mordant, observations of his own Minima Moralia.

Dialectic of Enlightenment begins with the assertion that enlightenment, an "advance of thought" that "has always aimed at

11. James Gordon Finlayson, "Adorno on the Ethical and The Ineffable," http://Www.sussex.ac.uk/Users/jgf21/research/AEI.rtf, (accessed March 1, 2010 ). J.M. Bernstein argues by contrast that Adorno identifies a "fugitive" ethical experience that provides glimpses of the good within an otherwise universal guilt context. J.M. Bernstein, Adorno: Disenchantment and Ethics (Cambridge: Cambridge University Press, 2001). 
liberating human beings from fear and installing them as masters," has proved a miserable failure: ". . . the wholly enlightened earth is radiant with triumphant calamity."12 In this sentiment, however, readers will hear a chorus of modern agreement. The paradigmatic bourgeois sociologist Max Weber famously identified the form of social and economic life that, in his reading, grew out of Protestant asceticism and that manifested itself in capitalist instrumental bureaucratic rationality in similar terms. Modernity is an inescapable structure, exerting "an increasing and finally an inexorable power over the lives of men [sic] as at no previous period in history."13 Weber saw the United States as the epitome of the exclusive pursuit of wealth, "stripped of its religious and ethical meaning," and divorced from any serious rational justification, which was the ultimate legacy of a religious movement that, like all significant change in any part of an interpretively lived economic and social system, had its seismic impact on every part. ${ }^{14}$

Weber himself exemplified and defended the terrorizing rationality of the modern face of the European enlightenment in his principled refusal to pronounce in public the value judgments he seemed to hold privately.15 In "Science as a Vocation," he insists on the ultimate

12. Max Horkheimer and Theodor $\mathbf{W}$. Adorno, Dialectic of Enlightenment, ed. Gunzelin Schmid Noerr, trasns. Edmund Jephcott (Stanford: Stanford University Press, 2002), 1. The work was first published in 1944, and reissued with substantial additions, notably a chapter by Adorno on anti-Semitism, in 1947.

13. Max Weber, The Protestant Ethic and the Spirit of Capitalism, translated by Talcott Parsons (New York: Charles Scribner's Sons, 1958) 181. Weber's essay dates originally from lectures given in 1904 and 1905, and initially appeared in English translation in 1930. Although final credit for the famous image of the "iron cage" apparently belongs to Weber's translator, Talcott Parsons, Weber clearly did describe the bureaucratically organized and rationally legitimated economic and social formation of Protestant capitalism as imprisoning, and as leaving little scope for ethical resistance. See Stephen A. Kent, "Weber, Goethe, and the Nietzschean Allusion: Capturing the Source of the 'Iron Cage' Metaphor," Sociological Analysis 44:4 (Winter, 1983) 297-319.

14. Weber, ibid., 182.

15. See, for example, his conclusion to Protestant Ethic and the Spirit of Capitalism: "But this brings us to the world of judgments of value and of faith, 
irreconcilability of the separated value spheres, and draws the conclusion that ". . it is necessary to make a decisive choice" on the basis of value commitments about which "nothing can be said in the classroom."16 What could be said in the classroom, however, was that ". . the genuine official . . will not engage in politics. Rather, he should engage in impartial 'administration'" as a matter of honor. ${ }^{17}$ The fully "administered world," to which Adorno referred with a shudder appears here already in full view. ${ }^{18}$ Its dutiful functionaries already can be seen to act mechanically and rationally in accordance with the dictates of the administrative apparatus to which they swear fealty, rendering ineffective if not entirely irrelevant whatever independent ethical reasoning they might still be capable of in such a world. More than one line of reasoning indicated that the extent of that independent ethical reasoning might be frighteningly limited. Adorno's "arch-enemy, Martin Heidegger," for instance, could bewail the increasing dominance of an alienated technology, as instrumentality and as human subjugation of nature, in his text on "The Question Concerning Technology," which appeared shortly after Dialectic of Enlightenment. ${ }^{19}$ There, Heidegger draws out a view of the essence of technology as a

with which this purely historical discussion need not be burdened." Weber, ibid., 182 .

16. Max Weber, "Science as a Vocation," in From Max Weber: Essays in Sociology Translated, edited and with an introduction by H.H. Gerth and C. Wright Mills (New York: Oxford University Press, 1946) 129-156, p. 152.

17. Max Weber, "Politics as a Vocation," in From Max Weber: Essays in Sociology, Translated, edited and with an introduction by H.H. Gerth and C. Wright Mills (New York: Oxford University Press, 1946) 77-128. Weber's distinction between politics and administration entailed that "The honor of the civil servant is vested in his ability to execute conscientiously the order of the superior authorities, exactly as if the order agreed with his own conviction. This holds even if the order appears wrong to him and if, despite the civil servant's remonstrances, the authority insists on the order. Without this moral discipline and self-denial, in the highest sense, the whole apparatus would fall to pieces." (p. 95) Weber, perhaps characteristically, does not discuss the relative merits of honor and other competing values in "Politics as a Vocation."

18. Adorno, Negative Dialectics, 448.

19. Jameson, Late Marxism, 9. Jameson reminds us here that Adorno assessed Heidegger's philosophy as "fascist to its innermost cells." Heidegger's essay on technology appeared in 1954. 
particular mode of man's relating to the world as it comes forward to reveal itself to man. ${ }^{20}$ In that mode, which "enframes" or stands outside its objects and encounters them exclusively as items of inventory ["standing-reserve"] for this or that presupposed task, "[man] comes to the point where he himself will have to be taken as standing-reserve."21 At the same time, it seems increasingly clear to man that he "everywhere and always encounters only himself."22 The extreme danger this situation represents makes it increasingly possible, although not necessary or inevitable, that human beings will utterly fail to encounter themselves in any other way than as items of inventory for pre-assigned tasks, and completely fail to encounter the world in any other mode of "unconcealing," leading to any other historical destiny for humanity and its world. ${ }^{23}$

Heidegger sees the power of art, as an alternative "revealing," as something which might heighten the ambiguity of technology and prompt the "rising of the saving power" in the face of it. ${ }^{24}$ His ontological analysis incorporates no constitutive analysis of the sociological arrangements under which both technology and art have so far unfolded. These are for him explicitly not of the essence. ${ }^{25}$

A radically different method leads Max Horkheimer and Theodor Adorno to their superficially similar, but fundamentally opposed, conclusions in The Dialectic of Enlightenment. For them, the apotheosis of what they call instrumental reason eventuates in the triumph of irrationality and barbarism. This reason proves in its results not

20. Heidegger's English translator uses the term "man." In light of Irigaray's subsequent critique (see Ch. III, this work) the choice seems apt. 21. Martin Heidegger, "The Question Concerning Technology," in Basic Writings, ed. David Farrell Krell (London: HarperPerennial, 2008) 311-341, 332. 22. Ibid., 332 .

23. Ibid., 338-339.

24. Ibid., 339-340.

25. Ibid., 311 . 
other than the deepest unreason. For Horkheimer and Adorno, however, historical specifics are precisely of the essence. The historical conditions of the dialectical development of reason, and its working out in socially specific forms of economic and cultural relationship, mediate the development of this form of rationality. The situation in which this occurs does not spare any of its components, including every aspect of cultural production, and in particular cultural production for the masses - the commodities of the culture industries. ${ }^{26}$ Art, whether in the form of popular or high culture, is no refuge. For Horkheimer and Adorno, the avowedly value-free science that Weber championed was itself deeply enmeshed in the problem. Its own dynamic led away from life lived according to the values that resisted administration, and towards others, which in practice systematically erected barriers to the practice of alternative values. Certain value positions are built in to the operations of the enlightenment rationality institutionalized in bourgeois capitalism and its supporting social formation. Within the mode of life produced by and under this formation, things are getting worse not just in a technical sense, but in a material, social, cultural, philosophical and ethical one. The spectre that is haunting late capitalism is the spectre of an increasing inability to conceptualize, let alone choose in favor of, values that do not support the system and ideas that are not already sanctioned by the system. Recognizing the ultimate dysfunctionality of the system in its current form becomes increasingly difficult as alternatives to the system become more difficult to imagine.

The separation and irreconcilability of the value spheres, identified by Weber, is a direct consequence of the conception of the

26. Thus, Adorno will never simply identify art as the poiesis of the true into the beautiful, and certainly not in 1954 . 
Kantian autonomous rational subject according to Horkheimer's and Adorno's analysis. This subject is defined by its autonomy, its selfdirection. Every substantive principle that might serve to guide its deliberations appears to it as something externally imposed; reason "unmasks substantial goals as asserting the power of nature over mind and as curtailing its own self-legislation," and for that reason recognizes these substantive goals as inimical to its project of autonomous domination of nature. 27 "Nature" here comes to include everything that qualifies as "affect;" by extension, those forms of expression that do not take the form of "actual ideas," such as those found in art and religion, are regarded as incommunicably separate from "anything deserving the name of knowledge" both by positivist science and by post-Enlightenment irrationalism. ${ }^{28}$

Adorno and Horkheimer argue that rational progress oriented towards what was understood to be the mastery of nature appears not to work as envisioned. It turns back on itself, and produces irrationality. In their analysis, this has to do with the insistence on equating rationality with instrumentality, and the banishment of insecurity. Thus, what passes for rationality assumes the character of myth, necessity. Then, nature acquires a compulsive character. Its unexamined content in the form of compulsive human nature blindsides all attempts to bring human activity within the scope of voluntary and discretionary, chosen, human ethical activity.

Adorno's analysis of the "culture industries" further lays out reasons why culture fails to function as a repository of critical consciousness, why putative art or works of art cease to operate as ways to cultivate critical consciousness. In the culture industries -

27. Horkheimer and Adorno, ibid., 68.

28. Ibid., 72 . 
paradigmatically entertainment for profit, and advertising - the artful images offered to the populace have a hidden agenda. They encourage behavior and desires that help maintain the system. They dampen or deaden whatever consciousness might critique or oppose it. They present the satisfactions that are available within the system as adequate, but also as infinitely subject to postponement. The offerings of the culture industries refresh the tired workforce, replenishing their exhausted labor power for another day of wage slavery. In short, whatever ennobling or enlightening potential culture might have been thought to have in an earlier time and a different place is vitiated by its metamorphosis into a popular culture fully integrated with and integral to a capitalist system of production for profit and commodity exchange.

The analysis presented in Dialectic of Enlightenment exposes a world in which forces that harbored impulses towards liberation have taken a turn towards generalized oppression. The elements and offspring of rationality serve irrationality, a drive towards "self-preservation" that effects the destruction of life itself. Scientific and technical progress has become an instrument of domination in the present. "Technological rationality reveals its political character as it becomes the great vehicle of better domination, creating a truly totalitarian universe in which society and nature, mind and body are kept in a state of permanent mobilization for the defense of this universe."29

\section{Adorno's Philosophical Aim}

Adorno himself described the aim of his philosophical work as the effort to "use the strength of the subject to break through the fallacy

29. Marcuse, One-Dimensional Man: Studies in the Ideology of Advanced Industrial Society (Boston: Beacon Press, 1966), 18. 
of constitutive subjectivity." ${ }^{30}$ In this description, the reader can hear the echo of a deep dissatisfaction with German philosophy's turn to the subject with Kant, and the inadequate salvation of the concrete in every proposed solution from Hegel through Husserl to Heidegger, all of whom come in for specific criticism in Adorno's major exposition of his philosophical method, Negative Dialectics. The problem is that the philosophical tradition has provided, so far, an inadequate account of the relationship of the subject and the world of objects given to the subject to know - including the subject itself as its own object of knowledge. Adorno's verdict on the effort is that "traditional philosophy" in "confusing itself with what it intends to interpret" has been an obstacle to the truth it ought to have been a vehicle to comprehending. ${ }^{31}$

Moreover, the presentation of closed systems of thought makes the world itself seem closed. As Horkheimer and Adorno demonstrate in Dialectic of Enlightenment, as discussed earlier, this appearance takes on a determinative force through the mediation of a social system built on its conceptual foundation. The theory of closure aids and abets social practices that reproduce a world with shrinking opportunities for imaginative resistance and transformation.

An anti-totalitarian concern characterizes Adorno's work generally. The related treatment of the relationship of the subject of consciousness, knowledge and truth to its concrete material object constitutes a deep element of his utopian discourse. In pursuing this central theme, his work spans a wide range of contributory problems and

30 Adorno, Negative Dialectics, xx. It would be customary to use the term "project" here to designate Adorno's philosophical ouevre, but this seems wrong in light of Adorno's dismissive association of the word with the "jargon of ontology." See Theodor Adorno, "Why Still Philosophy," in Critical Models: Interventions and Catchwords, translated and with a preface by Henry $w$. Pickford (New York: Columbia University Press, 1998) 5-17, 8.

31. Adorno, "Why Still Philosophy," 13. 
issues. He investigates its manifestation relentlessly in particular social, cultural and aesthetic issues, including the relationship of presentation or form to content, the incorporation of social contradictions in works of art and the modes by which works of art, including music, represent or express objective tendencies and social contradictions and possibilities. He focuses as well on methodological issues, and here particularly the relationship of the preparation of philosophical texts to the representation of ideas. ${ }^{32}$

While some of his work was impelled by circumstances of his exile in the United States during the late $30 \mathrm{~s}$ and $40 \mathrm{~s}$, even this work can be seen to cohere with his overall project. Looked at from outside, there is a critical element present in all of Adorno's work that links his thoughts on the culture industries, his earliest expression of his philosophical thought in "The Actuality of Philosophy," his work on Kierkegaard under the supervision of Paul Tillich, his critical social commentary, and his later aesthetic theory. Seen from this perspective, Adorno's project has to do with the theorization of a relationship between the thinking subject and a world that, while it changes historically, and while its operations also change the subject's experience in material and consequential ways, can be grasped through thought that concerns itself with truth. This thought, in turn, can have some impact on human activity and social prospects for change, on the cultivation of a humanity that goes beyond the sheer domination of, and by, "nature," and that reaches for the humane and collective life possible to a genuinely enlightened, and therefore free, humanity.

32. Here it is possible to see the influence of Walter Benjamin's theoretical discussion at the introduction to The Origin of German Tragic Drama, where Benjamin depicts philosophy pre-eminently as the realm of the representation of ideas. Walter Benjamin, ibid. 
Adorno's project is, then, an emphatically humanistic one, in what was to become a "post-humanist" era.

While Adorno's project seems abstract, his explicit commitments consist in a turn towards the concrete. As he says in one of the more impassioned and utopian passages in Negative Dialectics, the very consciousness of possibility that drives thinking on, through its distance from the content of thought, "sticks to the concrete as the undisfigured." Here, "thought is its servant," the "prism in which its color is caught." 33 This commitment to the concrete expresses itself in his tenacious methodological insistence on the possibilities inherent in dialectical reasoning, mobilizing dialectics in every substantive engagement with whatever subject matter. ${ }^{34}$

Adorno consistently refused to advance facile political solutions, frequently expressing the insight that practical political action in the circumstances of the day frequently played into the agenda of the system itself. Rather, his texts find him seeking the indispensable theoretical grasp of those principles which appear only in the particular political situation.

While Adorno clearly refused to participate in certain political movements during his own time, and while this refusal became a cause for dissatisfaction among politically engaged colleagues and students, the import of his political practice seems consistent with his deeplyheld philosophical principles and commitments. These are relevant, in particular, for a consideration of Adorno's utopian enunciations. His

33. Adorno, Negative Dialectics, 57.

34. Adorno's insistence on the dialectical structure of thought and of truth was at the center of his famous debate with walter Benjamin over Benjamin's work on Baudelaire, a methodological disagreement with grave personal consequences on both sides. See Susan Buck-Morss, ibid.; Hannah Arendt, "Introduction: Walter Benjamin: 1892-1940" in Walter Benjamin, Illuminations: Essays and Reflections, edited and with an introduction by Hannah Arendt, translated by Harry Zohn (New York: Schocken Books, 1968) 1-51, 10-11; Giorgio Agamben, "The Prince and the Frog: The Question of Method in Adorno and Benjamin," in Infancy and History, 117-137. 
recurrent criticism of impassioned political activity in his own time hinged on his insight that it often proceeded in the absence of the necessary depth of thought and understanding. ${ }^{35}$ Adorno does not insist that basic philosophy has political significance casually or, ultimately, mistakenly. Despite the frequently-noted absence of strategic or tactical political recommendations in Adorno's work, and sometimes a sense of bafflement at how his work might be "useful," his thought asserts its own political significance, and contains implicit principles for political practice. ${ }^{36}$

The political significance of Adorno's philosophical work and the political principles implicit in that work effectively assert the political significance, though not the actual political efficacy, of art in its various forms. Both art and philosophy, in different ways and relying on different "technical procedures," depend on the "consciousness of needs," which forms a portion of the truth both art and philosophy express. ${ }^{37}$ Adorno's scattered but persistent references to religion intimate the political significance of that arena of human practice as well, again without presupposing the practical efficacy of religion. For instance, there is a moment of truth in religion, for all its mythic content, although the only responsible position with respect to religion is "an extreme ascesis" that amounts to "an extreme loyalty to the prohibition of images, far beyond what this once originally meant."38 Not coincidentally Adorno's explicit leaning to the concrete, related to the perception of the significance of the aesthetic, makes

35. Russell Berman, "Adorno's Politics," in Adorno: A Critical Reader, Nigel Gibson and Andrew Rubin eds. (London: Blackwell, 2002), 110-131; Susan BuckMorss, ibid.

36. "It is incumbent upon philosophy . . . to provide a refuge for freedom." Adorno, "Why Still Philosophy?" 11.

37. Ibid., 14 .

38. Horkheimer and Adorno, ibid., 144; Theodor W. Adorno, "Reason and Revelation," in Theodor $\mathrm{w}$. Adorno, Critical Models: Interventions and Catchwords, trans. Henry W. Pickford (New York: Columbia University Press, 1998) $133-142,142$. 
his philosophy profoundly corporeal. ${ }^{39}$ The thought process of utopian reflection does not annul its object's original and ultimate connection to the body and bodily human life, and the relationship of art and religion to material and bodily life establishes their potential insights.

Adorno's work maintains a tenacious hopefulness about the prerequisites for utopian thought, in the face of impediments that his work draws out with painstaking clarity. This peculiar combination of rigorous honesty and tenacious refusal to abandon all hope informs his method and style. Both method and style figure as integral parts of Adorno's project, rather than as incidental consequences, arguably more than with many other philosophers. ${ }^{40}$

It may be fair to say that Adorno's project is the rescue of utopian possibility in the face of the objective disaster of the 20th century. This reading sees the philosophical groundwork accomplished in Negative Dialectics as the indispensable prerequisite to this rescue, which identifies the difficulties besetting the western philosophical tradition, and in particular German Idealism and its materialist critics, around the theory of the relationship of the subject of conscious contemplation to the object thereof. The dilemma posed by the question of whether knowledge is only possible by "the same," or whether knowledge of something actually different is possible, delimits the possibilities for utopian thinking as well.

39. Lisa Yun Lee, Dialectics of the Body: Corporeality in the Philosophy of T.W. Adorno (New York: Routledge, 2005).

40 On Adorno's specific style, see Rose, ibid., in particular chapter one, on style. Most commentators mention Adorno's difficult style, which poses issues of translation as well as understanding. See Buck-Morss, ibid.; E.B. Ashton, translators note, Adorno, Negative Dialectics; Robert Hullot-Kentor, translator's note, Adorno, Aesthetic Theory; Martin Jay, ibid. On the fundamental question of style, see the superb discussion in Francis-Noël Thomas and Mark Turner, Clear and Simple as the Truth (Princeton: Princeton University Press, 1994). 
Utopia is, or perhaps more precisely would be, if it were possible to describe it, a state or condition of reality different from the one in which people find themselves or come to recognize themselves as thinking and acting subjects. This makes the question, of whether thinking can come to a knowledge of someone or some thing really different from its subject, one of first importance. What kind of knowledge of utopia, of anything like the content of utopia, can be had? Can this knowledge be counted as knowledge at all or would it merely be the projection of something lacking in the present into an imaginary future? The answer given bears on any conceptualization of the utopian state or condition. It bears as well on the possibilities for any eventual approach to that state.

Adorno's efforts to rescue utopian thinking proceed via emphasis on exploiting chinks in the armor of an increasingly demonic understanding of rationality. His references to "micrological" approaches need to be understood in this way. He searches out tiny crevices of difference between one thing and another, the slight and occasional differences between a name and its habitually understood referent, the almost trivial but telling contradictions that beset definitions, formulae, and cultural arrangements, in order to obtain glints of light from the realm of the "non-identical."4I His procedure works, if it works, something like prying open the lid of a box from the inside, using the thin logical tools at hand for the liberation of the deadened western imagination. It works, if it works, by turning logical precision against itself, demanding of its identities even more rigorous

41. For instance, many of the fragments in Minima Moralia demonstrate that popular cultural equations ("love is marriage," "responsibility is hard work," "culture is appreciation of this particular form of art") fail. 
correspondence, so as to expose some actual remainder of non-

correspondence, as the field of possibility. ${ }^{42}$

\section{The Relation of Utopia to Adorno's Work}

Adorno qualifies as a utopian thinker in the precise sense that his thought develops with a potential utopian outcome in view, and has as its aim the theorization of the prerequisites for a thought that might grasp the truth content of utopian ideation and practice. Utopian thought surfaces in Adorno's key works explicitly, and he returns again and again to the concept of utopia. The explicit mention of utopia inaugurates and concludes Negative Dialectic; it surfaces in Minima Moralia; it anchors Aesthetic Theory; it hovers in his exegesis of the work of Samuel Beckett and the modernist visual artists. More significantly, Adorno's texts endeavor to identify the possible spaces for the perception and the cognition of differences between the current state of the world and some alternative, and the practice of thought which conserves those spaces.

The possibility of thinking outside the existing state or condition of the world, and the possibility of the truth of such thinking, sets the outer limit on the possibility of utopian thinking that carries hope in its train. Theorizing the possibility of precisely this thinking emerges as Adorno's key project, which underlies his treatment of the relationship of subject and object in Negative Dialectics, and his defense of the negativity of modern art in Aesthetic Theory, as well as his ironic vignettes in Minima Moralia.

42. Adorno's concern with tautology, false copula, and the character of metaphor are all relevant here. If logic proceeds through the exposure of implications and equations, and also through the Aristotelian exclusion of certain simultaneous identities, the job of negative dialectical method becomes that of finding the ragged edges, the non-correspondences, the failures of these seemingly watertight identities. It depends on finding the concrete and precise points in which propositions of the form " $x$ is $a$ " or " $x$ is $y$ " do not hold. 
The notion of utopia figures early in Adorno's philosophical efforts, and the relationship of reality to utopia, for better or worse, is a constant feature of his work. The specific understanding of utopia never strays far from that articulated by Marxist philosopher Ernst Bloch in The Spirit of Utopia, which had a profound effect on members of the generation that had experienced the First World War. Bloch's work was a pastiche of German idealism, materialism, Christian symbolism and references to Jesus, and mystical. romanticism, all advanced in a lyrical, evocative prose style that defies easy analysis. Adorno read it as a young man and claimed it as a decisive and permanent influence on his intellectual life, later identifying it as one of the most influential books he ever read. ${ }^{43}$ Thus utopia as a concept figured in Adorno's intellectual consciousness from an early point. Adorno's thinking continued to echo the basic picture that emerges from the Spirit of Utopia, with its stress on the "not-yet" and the openness of reality to transformation.

Bloch's main idea is that the human being strives forward towards something new, not yet in existence, that captures the utopian spirit. This longing evinces itself in dreams, cultural fantasies, sexual relationships, music. Utopia as presented by Bloch has the structure of something that has to be brought into existence from elsewhere, from a place of non-being. More precisely, utopia comes from non-being of a special kind, because Bloch talks about utopia as if it is something "there" in a real sense, something that guides its own actualization. In this sense, utopia shares a characteristic of the Hegelian world spirit, but without its guarantee of ultimate self-actualization in a

43. "I do not believe I have ever written anything without reference to it, either implicit or explicit." Theodor W. Adorno, Notes to Literature Vol. 2, trans. Shierry Weber Nicholoson (New York: Columbia University Press, 1992), 212. 
cultural form. While this something does not yet characterize the reality in which we live, it is the reality into which we live, or might if we live rightly. It is not "not" in a simple sense. Its negative relationship with the existential present is more complicated; this not-yet (noch nicht) cannot be described as "existing," and yet it constitutes a critical element of reality.

The notion of something that is real, and in a special sense existent or present, in spite of its inhabiting a space of non-being, is vital for Adorno's own discourse. The continuing reality of the possible future, the world that could be made, is the source of hope that some key values might be realized. On the other hand, the specific contours of this "not-yet" seem likely to be affected by history, both as past and as future. What has happened modifies and what will happen in the historical realm of existence affects the contours of the notyet as well.

Utopia, then, shares the status of every work of art, which has to be wrested from this realm of non-being, created and creatively brought into the realm of the existent. This is one of the reasons art itself particularly points in the direction of utopia. Art is that transformative collective fabrication that has not yet been organized and achieved.

Adorno's work turns on the question of how this legitimate imagination of an alternative situation might be secured philosophically - again, demonstrated as possible and defensible. His philosophical effort includes critical engagement with those schools of philosophical thought which definitively eliminate this alternative mode of thought; his critical project raises objections to those cultural formations and phenomena that conspire to do the same thing practically through the manipulation of popular cultural products. His 
thought attends to the prior structures imposed on thought itself by its concrete situation, and seeks to find a way out of the predeterminations of this prior structure, this constructive situation, which threaten to make thinking of what it does not already contain strictly impossible. In this very precise sense, Adorno constitutes a most important utopian thinker of the late 20 th century.

The Actuality of Philosophy

One of the best places to observe this characteristic is in Adorno's inaugural presentation "The Actuality of Philosophy," where he does not mention "utopia," but criticizes an established philosophical ideal, which has implications for a preliminary understanding of utopia, namely that of grasping the underlying rational system of reality. The notion that "the power of thought is sufficient to grasp the totality of the real" has to be abandoned by the would-be contemporary philosopher. ${ }^{44}$ To the extent that we can use that guiding aspiration as an index of an earlier, philosophically-defined utopian moment, and that is to a large extent, then Adorno's understanding of the philosophical utopia, and of its relationship to the more concrete and popular utopia, diverges radically from that philosophical ideal.

Already in "The Actuality of Philosophy" Adorno lays out some of the main themes that will structure his thought during the next three decades, and in which his discussion of utopia will figure. These include his opposition to the imposition of an alien, allegedly rational systemic unity upon reality, whether in a strictly conceptual way, or through the actual creation of such a system in the reduction of reality to that which can be treated within such a system; the objectively ascertainable inadequacy of reality to the structural

44. Theodor $w$. Adorno, "The Actuality of Philosophy," in The Adorno Reader, Brian O'Connor editor (London: Blackwell, 2000) 23-39, 24. 
limits of rational thought; the inherently historical, and therefore also changeable, character of both object and subject; and the need to focus thought and analysis on the concrete and particular. Ultimately, Adorno's sympathy with the concrete does not rest in the relationship of the particular to the universal. It would be possible to care about the concrete entity or situation because it is a convenient point of access, and because it is a microcosm or analog of a universal that is of greater intrinsic interest. This is not Adorno's point. If anything, the priority is reversed: interest in the universal is for the sake of the concrete, and the recognition of its irreducible truth. O'Connor notes that Adorno is in "The Actuality of Philosophy" most clear in his efforts to define the contemporary task of philosophy. Contemporary philosophy here would include the philosophy of 1931, but could encompass the early decades of the 21 st century as well. Adorno urges the dissolution of pressing, concrete situational questions in illuminating interpretations which show a practical way forward into productive human activity. Adorno's substantively utopian political program is on display in "The Actuality of Philosophy." Political action needs a footing in ideas, and not just any ideas, but ideas that embody the proper, illuminating interpretation of concrete elements drawn from existing reality. These interpretations give insight into the actually existing character of the situation, and "make it possible to recognize the demonic elements." They annihilate the "riddle" posed by the juxtaposition of those elements in the experiential situation in the solution, their coming together in an interpretive flash that grasps the whole in a new way. ${ }^{45}$

For Adorno, the task of the philosopher is pre-eminently to shed light on the situation into which politics will be required to act.

45. Adorno, "Actuality," 31. 
More precisely it is to open up and release the light that will emanate from the elements themselves, once they have been placed in proper configuration.

Elsewhere in the same address, he speaks of turning the ciphers into a text. What emerges from his discussion here is a picture of reality that is messy, significantly irrational and non-systemic, but far from entirely meaningless. This is a reality that resists all philosophical efforts to identify its single "engine" or central principle. This reality not only does not necessarily have a single engine or driving force, but not all of its elements and processes are smoothly articulated into a functional system. Adorno refuses to make the mistake of imputing a functionalism to a system that has not been observed. The scholar or interpreter of the situation cannot make such statements about the whole, in Adorno's view, for significantly intellectual reasons: it involves theorizing in advance of the data. We do not know enough about this fragmented, partial, obscure real situation to make such sweeping statements. In part, this structure of the real is what prevents our turning the ciphers into a text; things are missing - either actually, because what earlier philosophers had hypothesized as mechanisms of coordination are simply lacking, or seemingly, because we do not have the appropriate viewpoint from which to observe them; indeed, when it comes to the human unconscious, it may be that no one has this viewpoint.

In "The Actuality of Philosophy," Adorno rejects both of two dominant philosophical alternatives. On one hand, he dismisses the systematizing efforts of the earlier German idealists and the tradition from which they emerge, as impossible. On the other, he deplores the reductionist efforts of the Vienna School and logical positivism to reduce the scope of philosophy to that which can be grasped by the 
autonomous reason. The idealists reach too far; the positivists do not reach far enough and end by creating contradictions of a different sort. They fail to give an adequate account of the intelligibility of other consciousnesses, just as they are unable to resolve the problem of the "given," and its historically changing character. ${ }^{46}$

In contrast to both, Adorno advances a different philosophical method. "Plainly put: the idea of science (Wissenschaft) is research; that of philosophy is interpretation."47 The horizon of the philosophical ideal Adorno describes in this discussion becomes one of illuminating interpretation. This is not, for Adorno, the kind of interpretation that seeks the hidden meaning embedded in or lodged obscurely behind words or figures, as if it were an arcane treasure. That particular exegetical enterprise would be better left to a different kind of interpreter. Rather, he elaborates his view of interpretation as the solution of "riddle figures of that which exists." ${ }^{48}$

The metaphor of the riddle becomes central to the presentation in "Actuality." In a riddle, a particular configuration of words and ideas is presented in such a way that the configuration itself creates a puzzle, a momentary (or more than momentary) bafflement. When we are given a riddle, we usually know at least something about all of the terms. We know the "meanings" of the individual elements; we know a superficial reading of the configuration. The problem is that it is clear that the superficial reading can't be the "right" one, if it is not one that makes all the individual pieces, and their relationship as a whole, resolve into a whole that also includes its answer. When that kind of reading is found, the "riddle" in a vital sense disappears; it

46. Adorno, ibid., 30.

47. Adorno, ibid., 31.

48. Adorno, ibid. 
is no longer a puzzle, a source of bafflement, but has become "one I've heard before." It is no longer a question, but a move to which the hearer knows the response. That response then prepares the ground for the next step, whatever that next step is.

There is, then, something about truth which, in such a riddling context, will be self-validating. One index of truth will be that it accompanies an actual or workable resolution to the puzzle presented by the situation, and "negates" the question present in the intelligible configuration of elements. A touchstone of truth becomes, then, not its correspondence to particular a priori conditions, but its relationship to the concrete, precise demands of the situation. This recognition of truth on the basis of its fit with elements, consequences, and experience does not, however, make of truth either an arbitrary or "subjective" phenomenon. On the contrary, its precise attunement to the requirements of the available evidence, and its relationship to conceptual clarification of the fragmentary character of the data, make this understanding of the recognition of truth both objective and exacting

Adorno asserts a precise connection between his own conception of philosophy as interpretation and the mode of analysis in use by materialism. According to Adorno, "[i]nterpretation of the unintentional through a juxtaposition of the analytically isolated elements and illumination of the real by the power of such interpretation is the program of every authentically materialist knowledge . . ."49 As with the solution to a "riddle," materialist analysis, perhaps exemplified by Marxist "unmasking" of reified constructs and objective social relations, throws always already accessible experiential evidence into suddenly more intelligible relief,

49. Adorno, ibid., 32 . 
so that the requirements of action also become more clear, if not absolutely clear. Adorno's example is the Marxist analysis of the commodity structure. That analysis not only does not solve the philosophical problems posed within the Kantian framework - the "thingin-itself problem" - it does not even address that problem, or acknowledge it as important, since its aims point thought elsewhere. Adorno's presentation does assert that philosophers have to be willing to face the risk of the "dissolution of philosophy," but this seems disingenuous, since he earlier notes that some of the central problems of the philosophical tradition will be addressed under this new approach. ". . . [T] fune function which the traditional philosophic inquiry expected from meta-historical, symbolically meaningful ideas is accomplished by inner-historically constituted, non-symbolic ones." 50 It is clear, however, that the outcomes Adorno seeks will not satisfy certain demands. There will be no deities or transcendent world spirits that underwrite an ultimate optimism about the trajectory of reality, or that guarantee the ultimate resolution of the contradictions and dilemmas of the real situation in a redeemed future. The disciplined philosophical mind will confine itself to the territory circumscribed by the concrete elements available to it. It will produce - manufacture - useful constructs, but it will not presuppose a particular outcome. It will seek to explain, and then check to see whether its explanations might offer grounds for future hope. This discipline is to prove exacting and uncompromising as the elements of the real situation that Adorno's philosophy is required to grapple with pile up historically. It will ultimately prevent Adorno from taking certain kinds of refuge in recycled theological and artistic ideas and dreams of redemption

50. Adorno, ibid., 33. 
whose validity seems to have been vitiated by the events of the first half of the $20^{\text {th }}$ century.

It is significant that Adorno calls his presentation the "actuality" of philosophy, and once again, he turns to the comparison of materialism with his vision of a reclaimed and principled philosophy to make his case clear. The dialectical process whereby a riddle is illuminated and negated "is executed in earnestness by materialism," by which he means "that the answer does not remain mistakenly in the closed area of knowledge, but that praxis is granted to it." ${ }^{51}$ The consideration of philosophically interesting problems leads to some change in the reality that throws the problems up for analysis, and this change in the reality generates new, modified problems, and so on. This dialectic can be understood and to a degree anticipated, but the program of philosophy to which its practice will give rise can, clearly, not be outlined in advance. It is, of necessity, a program of philosophy that will have to remain radically responsive to the everarising concrete problems of its day. And while, as we have already seen, this does not mean that the knowledge of philosophical tradition, with its possibly meaningful "threads" of argument and insight, becomes superfluous, and while it does not mean that the "large" philosophical questions will simply no longer be addressed, it does mean that the matters most urgently before philosophers will change with the times in ways they might not have imagined heretofore.

One way of characterizing the approach Adorno lays out in "The Actuality of Philosophy" is to say that it is the illumination of the recurrent principles or operating elements of a reality that it is not possible for the mind to grasp in its entirety. Nevertheless, becoming aware of the state of things in our local area - and by local, we might

51. Adorno, ibid., 34. 
mean century or contemporary world situation, not necessarily our village or even country - attuning ourselves to a precise, "micrological" understanding of that reality that leads to some concrete prescriptions for action, becomes the contribution of the serious philosopher to the urgent task of the humanity with which she or he shares both time and place. ${ }^{52}$

We might notice that Adorno already sees the entrance of "the separate disciplines," and particularly sociology, into the picture. Where Heidegger accuses the sociologist of being a burglar, Adorno turns the accusation on its head, embracing the burglar's occupation, under the dire present circumstances. When the whole of western culture seems more analogous to a house that is falling down around the ears of its residents, the burglar will at least salvage something from the disaster. ${ }^{53}$ When the world is on fire, the New Leftists of some later decades thought, what's urgently needed is action. For Adorno, however, it always seemed more necessary to understand what the fire was really burning, perhaps even at the risk of being burned by it oneself.

\section{Utopia in Negative Dialectics}

Adorno in Negative Dialectics is specifically grappling with the pressing problem, not yet solved to his own satisfaction, of the relationship of the subject of such an understanding of the real to the objects of its understanding. Adorno's aim is to develop a solution different from what western philosophy has so far attempted in the solution of that problem. Adorno is dealing specifically with the structure of consciousness, or in other words, with the structure of rationality - and with its significant possibilities for irrationality,

52. Adorno draws his notion of the "micrological" from Walter Benjamin, whose work on the origin of German tragic drama figured as his first seminar at the University of Frankfurt. See Brian $O^{\prime}$ Connor, ed., The Adorno Reader, 23-24. 53. Adorno, ibid., 35. 
which he takes fully seriously, along with that structure's disturbing historical contingencies, and the dawning of the awareness that the physical substrate of consciousness poses significant issues for insight into the structure of rationality as well.

Thus, in Negative Dialectics, Adorno deals also with the subjectobject structure that has permitted western philosophers to talk about "transcendence" as if it were something that people understood. In fact, it is this structure that has permitted philosophers since the early Greeks to talk about "understanding" as if it were something that people did, and was an unproblematic tool of knowing and dealing with the concrete world around them. The extent to which the world around them was also "in" them, and to which they were also "in" the world around them, and the extent to which this posed dire problems for practical activity as well as for philosophy, was left to the late $20^{\text {th }}$ century to appreciate more fully.

Adorno's commitment is precisely not to give up on the ultimate program of philosophy, that of understanding the reality in which humankind finds itself. "The cognitive utopia would be to use concepts to unseal the non-conceptual with concepts, without making it their equal."54 Adorno's program is still a program of conceptual understanding, of formulating conceptual truth about reality which will provide genuine understanding of and insight into that reality. The reality with which he is specifically concerned has become the way people approach an understanding of their relationship to their world, and the possibilities for rational understanding of that relationship, that is, for understanding that has a reasonable claim to have grasped the truth of or about that reality.

54. Adorno, Negative Dialectics, 10. 
Another way of saying the same thing, which emphasizes the role of subjectivity and its possible consequences, is to say as Adorno says in the 1966 preface to Negative Dialectics "To use the strength of the subject to break through the fallacy of constitutive subjectivity this is what the author felt to be his task ever since he came to trust his own mental impulses. . ."5s Along with this, as a "determining motive" is the wish to "transcend the official separation of pure philosophy and the substantive or formally scientific realm . . ."56 Where philosophy has been seen as something that has to do with strictly mental phenomena, the realm of the mind as divorced from, separated from the world around it, and as speculative rather than experimental, Adorno casts it differently. Drawing on "The Actuality of Philosophy," we notice that Adorno is advocating experimental procedures for philosophers. These experimental procedures will have to do with precise consideration of concrete things, not just taking refuge in conceptual abstractions as if these will suffice for the method of philosophy.

In the quest for a society fit for human beings, in the quest for the right world, philosophy is not irrelevant, but it will have to be the right kind. Famously, Negative Dialectics begins with the assertion "[p]hilosopy, which once seemed obsolete, lives on because the moment to realize it was missed."57 A complex historical discourse around utopia is already embedded in this first line. The reference is to Marx's 11th thesis on Feuerbach: "The philosophers have only interpreted the world, in various ways; the point is to change it." ${ }^{58}$

55. Ibid., 9 .

56. Ibid.

57. Ibid., 3 .

58. Karl Marx, "Theses on Feuerbach," in The German Ideology Part One with Selections from Parts Two and Three and Supplementary Texts, ed. C.J. Arthur (New York: International Publishers, 1974) 122-123, 123. 
Marx, and even more, Engels, differentiated themselves from those who became, because of their allegedly less utopian approach to socialism, the "utopian socialists," like Fourier, Saint-Simon, Owen and Proudhon. Marx's "The Poverty of Philosophy" was directed against Proudhon's anarcho-socialism, an ellegedly utopian alternative. Nevertheless, as Adorno notes, "Marx and Engels were enemies of Utopia for the sake of its realization." 59 The role of philosophy, then, from the outset of Negative Dialectics, includes the rescue of the possibility of utopian thinking, namely, that thinking that can imagine an alternative to "the unspeakable world that is." ${ }^{60}$ In sum, Negative Dialectics begins in reference to an already-existing utopian discourse, and places itself in a specific relation to that discourse; it stands on the side of maintaining the possibility both of that discourse and of the practice that might carry it forward.

The idea of the utopian form as an effort to "enlarge the field of the possible" and explore its possible contents, going back to the creation of a space for imaginative exploration in the "no place" of Thomas More's 1516 work, is precisely that of utopia not as strictly impossible but rather as an exercise in distinguishing the possible from the utterly fantastic. ${ }^{61}$ In this sense, philosophy has from its inception had something to do with utopian forms. While there can be dispute about whether Plato's Republic and Laws constitute "true utopias," either formally or substantively, there is little dispute that the philosophical exploration of the ideal, and the possible, in

59. Adorno, ibid., 322. Adorno's discussion in these two pages $(322-23)$ is vital for the purpose of the work as a whole, with respect to the concrete need for philosophy. Also note the implicit critique of Biblical religion: "More in line with the catastrophe that impends is the supposition of an irrational catastrophe in the beginning." 323.

60. Adorno, ibid., 403.

61. "Introduction," Utopie, http://gallica.bnf.fr/Utopie/T1.htm, October 20 2008 
the context of the actual - at least, the actual as ascertained by the philosopher - characterizes those works. While utopian discourse is not an indispensable component of philosophical discourse, it is a classically-established, sanctioned element. Adorno plays on this fact throughout Negative Dialectics, even as he turns the traditional foundationalist philosophical method and many traditional philosophical concerns against the program of traditional western, and in particular German idealist, philosophy.

Adorno's explicit references to utopia in the text of Negative Dialectics are limited, and cluster in the introduction and the concluding section, "Meditations on Metaphysics," which he presents in the preface as a demonstrative experiment in the use of the negative dialectical method. ${ }^{62}$ Nevertheless, the relationship to utopia can be read as providing the structure of part two, Adorno's elucidation of the method of Negative Dialectics, as well. First, Adorno demonstrates the unattainability of the cherished utopia of the traditional philosopher, the dream of a total philosophy. ${ }^{63}$ He implicitly raises utopian concerns, such as the theme of reconciliation, which haunts the exposition of dialectics, as the form of a refused Hegelian synthesis: "What tolerates nothing that is not like itself thwarts the reconcilement for which it mistakes itself. The violence of equalitymongering reproduces the contradiction it eliminates." 64

This statement does not sound utopian at first blush. Adorno, however, is attempting to elucidate the relationship of consciousness to reality, beginning with the most general level. Similar issues arise at every other level of analysis as well, because this awareness of contradiction between something and its non-identical conceptualization

62. Ibid., 361-408.

63. Ibid., 136.

64. Ibid., 143 . 
is the engine of thought. Its nonidentities continue to emerge. Adorno is presenting an account of concrete socially-embodied reality. The postulate of a longed-for reconciliation - of people with one another, of humanity with its life, of consciousness with nature, we could extend possible reconciliations ad infinitum - becomes an implicitly utopian articulation. ${ }^{65}$ This is further emphasized by his statement about the role of theory two short paragraphs later: "Those who chide theory anachronistic [sic] obey the topos of dismissing, as obsolete, what remains painful as thwarted." ${ }^{66}$ Theory is no anachronism, and what is thwarted by the world as it is may not simply be dismissed as meaningless. Defying "the world's course" that does the thwarting, and helping to fulfill the desires so thwarted, is precisely what theory is supposed to do. Once again, theory is presented as a practical intervention in the "world's course." Theory pries open and holds open the space for an intellectual apprehension of that which differs, in precise ways, from the official or accepted representation of the world in which the theory is developed. This structure, of an intellect oriented towards extending the possibilities of the world, is the paradigmatically utopian structure as presented by Adorno.

Then, he works through the alternatives to the articulation of a utopia to be desired beyond the operation of any dialectics. Dialectics itself is a method confined to the current situation, and to the core or kernel of nonidentity which lies at the very heart of the most traditional philosophy. "Nonidentity is the secret telos of

65. It is important to distinguish those explicitly utopian references, and those references that might be construed as utopian because of the desiderata they contain, as does this reference to ultimate reconciliation. This statement seems worth including, in light of Adorno's embrace of Bloch, whose own identifications of utopian thinking are broadly inclusive.

66. Ibid., 143. 
identification."67 Instead of forcing things to become identical with their concepts, says Adorno, we need to recognize and acknowledge "the concept's longing to become identical with the thing." ${ }^{68}$ Here Adorno invokes Plato's ideas, in a passage that is as lyrical as it is explicitly utopian: the ideas are the "negative signs" of truth, the joining of pragmatism and utopianism, that live "in the cavities between what things claim to be and what they are," and that point to the possibility of " $A$ " becoming "what it is not yet." 69 The conclusion to this exposition of the ideas is then explicitly utopian:

"Utopia would be above identity and above contradiction; it would be a togetherness of diversity. For the sake of utopia, identification is reflected in the linguistic use of the word outside of logic, in which we speak, not of identifying an object, but of identifying with people and things." 70

In this critically important passage, in his discussion of the concepts and categories of the negative dialectical method, Adorno identifies at a very general level the content, or rather, the criterion of the utopian situation he has in mind. The utopian vision, then, sketches the objective of the negative dialectical method or program.

His exposition then proceeds to elaborate the method, rationale, and categories involved in the negative dialectical philosophical program: contradiction, and its rationale; in particular the category of negation; the position of the individual. Here we move closer, still implicitly, to utopian thinking once again, prefiguring something that will arise at the end of the section. The discussion leads into the category of the constellation. Finally, a discussion of the re-casting of the familiar concepts of essence and appearance within negative dialectics, and further discussion of other critical concepts finishes

67. Ibid., 149.

68. Ibid., 149 .

69. Ibid., 150 .

70. Ibid., 150 . 
the exposition. None of the discussion makes any explicit reference to utopia. Nevertheless, the exposition of the negative dialectical program, and the rationale for it, target a "world's course" that would eliminate the possibility of utopian thinking. The negative dialectical thinking developed by Adorno amounts to the cultivation of a form of thought that includes space for the idea of utopia. This space is held open by rejecting the (always premature) philosophical closure that is ardently desired by the thinking mind, but that most urgently threatens utopian perception.

Physicality and Suffering

What it means, ultimately, for negative dialectics to grant a preponderance of attention to objects, to give them their due, to resurrect the objective content of the subject, and so on, is ultimately to have posed one of the critical problems of humanity that humankind is physical existence with the potential to understand itself - which can also be construed as a togetherness in diversity. ${ }^{71}$ This peculiar human structure leads Adorno instantly to a consideration, in this context, of the problem of suffering, and its inextinguishable physical moment. Phenomena of consciousness are not exclusively phenomena of some abstract consciousness, but are "invaded" by a physical moment, the physicality of pain and suffering, or of happiness. "A happiness blocked off from every such aspect [of sensual fulfillment] is no happiness."72 Once more the question of utopia hovers around the text; the utopian impulse is precisely that towards the happiness of

71. Though it ought to be pointed out here instantly that the categories "mind" and "body" themselves are subject to the criticism of abstract categorization that is at the heart of the dilemma Adorno is trying to take apart.

72. Ibid., 202 . 
its inhabitants as the paramount question. ${ }^{73}$ Adorno's negative dialectical philosophy demands a serious consideration of the physical moment not just of human existence but of thought itself, and of the necessary consideration of that physical subjectivity in the reflection of thought. Whatever the post-revolutionary utopia would be,

". . . the telos of such an organization of society would be to negate the physical suffering of even the least of its members, and to negate the internal reflexive forms of that suffering. By now, this negation in the interest of all can be realized only in a solidarity that is transparent to itself and all the living." 74

This observation leads to a critique of the allegedly materialist antiutopian praxis. That praxis, epitomized by the state socialism of the USSR, allegedly builds on materialist dialectical philosophy. It fails not only to produce happiness, but to tell the truth, in an ideological insistence on thought being the representation of what it is thinking about.

In opposition to this (anti-utopian) assertion, Adorno posits a different theory of the relationship between thought and thing in the activity of thinking:

The materialist longing to grasp the thing aims at the opposite: it is only in the absence of images that the full object could be conceived. Such absence concurs with the theological ban on images. Materialism brought that ban into secular form by not permitting Utopia to be positively pictured; this is the substance of its negativity. . . Its great desire would be the resurrection of the flesh, a desire utterly foreign to idealism, the realm of the absolute spirit. ${ }^{75}$

73. With this are set aside temporarily both flawed utopias, in which some or all the inhabitants are actually unhappy - one thinks of Brave New World, for instance; and also those utopias in which some, or, in the limiting case, one, inhabitant is miserable - so, all utopias based on slavery, as in the Republic, or the still-flawed postmodern utopia, open to any specific happymaking content, that obscurely requires the meaningless misery of one, in Ursula K. LeGuin's "The Ones Who Walk Away from Omelas."

74. Ibid., 204.

75. Ibid., 207. 
In other words, the truth a genuine, as opposed to an ideological, materialism seeks is the substance of the material. Its transfiguration as an image, which could then abandon the material source, would betray that matter.

Thus, this critical programmatic section of Negative Dialectics actually begins with utopian considerations, moves through an elaboration of the philosophical considerations necessary to advance these considerations, and ends with a statement of the criterion for utopia. Utopia must be imageless, and in fact, cannot be arrived at by means of representational thinking. The hope of negative dialectical critique and this program of understanding is that it might escape the threat of idealism, as well as the threat of materialist dogmatism, and outline a way to pursue utopia through its pursuit of changing constellations, in order to pursue a utopia that is always in danger of being represented to death philosophically.

Semblance and Second Reflection in Aesthetic Theory

While utopia itself must remain imageless, images in the form of artworks can render a service to utopia. The "incomparable metaphysical relevance of the rescue of semblance, the object of esthetics [sic]" lies in the way this semblance of transcendence points towards something other than semblance and, at the same time, other than the already known world. Moreover, the relationship of the philosophical mind to that object, which it encounters in a material existence they both share, and in which it can recognize the traces of a "moment of transcendent objectivity" in which it also shares, constitutes "the unobtrusive site of metaphysical possibility."76 This insight,

76. Adorno, Negative Dialectics, 393. Lambert Zuidervaart translates what is of incomparable metaphysical relevance, Adorno's "die Rettung des Scheins," more beautifully, and suggestively from the perspective of 'messianic light,' 
delineated in the concluding sections of Negative Dialectics, also points explicitly towards the role Adorno sees for Kantian aesthetic categories, and prefigures the project that takes detailed shape in Adorno's Aesthetic Theory.

While Adorno's complex aesthetic theory deserves lengthy and detailed examination in its own right, this chapter restricts itself to identifying three aspects of central importance to its utopian moment, and in particular to its address to a subject of utopian possibility. ${ }^{77}$ Those are the way the methodology of aesthetic theory proceeds, by second reflection; the way the work of art reflects, and simultaneously fails to reflect, transcendence; and the significance of the work of art as an exemplar of creative praxis. Taken together, these points demonstrate the role the development of aesthetic theory might play in the cultivation of a subject of utopian possibility.

Aesthetic theory implicitly claims to be philosophy whose object is art. Adorno's editors note that his intended motto for his own Aesthetic Theory was a quote from Friedrich Schlegel, "What is called the philosophy of art usually lacks one of two things: either the philosophy or the art."78 The irony was more than casual. Adorno's planned introduction to the work makes clear his assessment that existing aesthetic theory failed to make good its promise, which is, or ought to be, the interpretation of the phenomenon of art, beyond the phenomena of individual art works, as a source of objective knowledge. ${ }^{79}$ From the side of philosophy, the truth content of art needs to be

\footnotetext{
as "the redemption of illusion." Lambert Zuidervaart, Adorno's Aesthetic Theory: The Redemption of Illusion (Cambridge, MA: MIT Press, 1991).

77. See, among others, Donald A. Burke, "Adorno's Aesthetics of Reconciliation: Negative Presentation of Utopia or Post-metaphysical PipeDream?" in Adorno and the Need in Thinking: New Critical Essays, eds. Donald A. Burke, Colin J. Campbell, Kathy Kiloh, Michael K. Palamarek and Jonathan Short (Toronto: University of Toronto Press, 2007) 233-260; Finlayson, "The Work of Art and the Promise of Happiness"; Jameson, Late Marxism; Zuidervaart, ibid.

78. Adorno, Aesthetic Theory, 366.

79. Ibid., 359 .
} 
rescued from an epistemological context in which it is automatically dismissed as false or irrelevant due to its difference from the empirical world. ${ }^{80}$ From the side of art, philosophy is to be called back to its footing in the effort to give voice to suffering, which is "a condition of all truth" and also that in which art's expression and form "has its substance," without which what it would be is, at present, unimaginable. ${ }^{81}$

For this task, Adorno proposes

Kant's theory is more apposite to the contemporary situation, for his aesthetics attempts to bind together consciousness of what is necessary with consciousness that what is necessary is itself blocked from consciousness. It follows its course, in effect, blindly. ${ }^{82}$

The reappropriation of Kant takes place, in part, in a redeployment of Kantian aesthetic categories: beauty, natural beauty, art beauty, spirit. Of greater interest here, however, is the specific appropriation of this Kantian "blindness" in what Adorno calls "second reflection." Second reflection is the philosophical counterpart to the first reflection of artistic praxis. It is interpretive, but not in the sense of seeking the "message" of the artwork, as if the artwork were frankly communicative. Instead, second reflection "lays hold of the technical procedures, the language of the artwork in the broadest sense, but it aims at blindness." 83 It gropes its way backwards from the monadic result that is the artwork towards a comprehension of the problem the artwork set out to solve, the tensions it was forced to try to resolve, and towards an understanding of the impulse that set the work on its course in the direction of "the old darkness of the new."84

80. Adorno, Negative Dialectics, 393.

81. Adorno, Negative Dialectics, 17; Aesthetic Theory, 261.

82. Adorno, Aesthetic Theory, 343.

83. Ibid., 27 .

84. Ibid. 
This philosophical encounter with the work of art is made necessary by the complicated status of art itself, and is inseparable from the "rescue of semblance" towards which Adorno's thought strives. "Art awaits its own explanation," since art itself operates non-conceptually, blindly groping towards the expression of its own truth from the side of its engagement with the concrete. ${ }^{85}$ This explanation must make its way dialectically back and forth between the complicated arrangement of truth and falsehood embodied in the work of art. The recognition of this complex and, in Adorno's presentation, objective inner-artistic relationship leads to the second point of emphasis, the way the work of art reflects and fails to reflect transcendence.

The work of art presents itself as a fact, but it is a complex fact, a fact with a history that does not speak directly about that history. What it speaks of, instead, is something that seems to be beyond or different from the empirical world, in that it occupies space in the empirical world - people can see it, hear it, feel it - but it registers some greater or larger difference from the way things actually are. The task of aesthetic theory is to grasp art's entrapment in concrete technical and social relations that dictate its materials and methods, to discern its actual technical achievements, and to understand beyond those specific concrete achievements the more general aim embodied by art.

Art is a form of fantasy. This exposes it to disqualification as simply lying wish fulfillment. But ". . . if art has psychoanalytic roots, then they are the roots of fantasy in the fantasy of omnipotence. This fantasy includes the wish to bring about a better world." ${ }^{86}$ Adorno proposes as a reasonably exact definition of fantasy "the differential

85. Ibid., 353.

86. Ibid., 9 . 
of freedom in the midst of determination," discernible in the "probably aporetic nexus of problems" to which the artwork represents a proffered solution. ${ }^{87}$ These problems, which in some real sense are all problems of material, incorporate the effects of the social totality and its contradictions, since they, too, are deeply sedimented in the artist's only available materials. ${ }^{88}$ The task of aesthetic theory is to uncover these problems, to analyze the contradictions facing the artist and to understand the work of art as a response to those problems and contradictions. At the same time, it is to perceive the contradictory impulses of the artwork as the response to art's impossible predicament, the concrete counterpart to the impossible predicament of philosophy:

The relation to the new is modeled on a child at the piano searching for a chord never previously heard. This chord, however, was always there; the possible combinations are limited and actually everything that can be played on it is implicitly given in the keyboard. The new is the longing for the new, not the new itself: That is what everything new suffers from. What takes itself to be utopia remains the negation of what exists and is obedient to it. ${ }^{89}$

While works of art modify the empirical world in critical ways, they remain fully within that world. At their most transcendent, they remain rooted in the matter of common life. Their illusory character, however, is not only a "promise of happiness" without any guarantee. It is also an ongoing invitation and provocation to think the thought of something different from the world that is. "Artworks are what they are able to become," and the task of aesthetic theory lies in trying to survey the distance between what artworks aim for and what they manage to achieve, by performing the redemptive task of "second reflection," re-reflecting what the work of art reflects in itself.

87. Ibid., 174.

88. For instance, Elaubert needs Emma Bovary to be married and to have a child. But for that reason, she must be an awful mother.

89. Adorno, Aesthetic Theory, 32. 
If aesthetic theory faces up to this task, it brings to light and cultivates an understanding of an aspect of the artwork that is deeply relevant to utopian thinking. That is the work of art's identity as a solution to a problem generated by the interaction of the subject with its world. As noted, the artist works with materials that are available to her, and these materials are themselves spirited, historical, social, political, and include the contradictions built into these materials, and the specific suffering they entail. The work of art is the existing mediation of the tensions latent in this situation; it does its best, if it is good art, to bring these into an internal relation, to resolve the tensions, to order them, to make something of them. This task, embodied as if complete in the work of art, is in essence also the task of art's audience with respect to their own problem. Art seems to manage, on its smaller scale, what people have yet to manage in the larger commission that is the creation of a cultured social whole. Because the work of art embodies the drive towards reconciliation, and because it illustrates the creative process of finding ways around the obstacles and through the aporias "given" to the artist, the work of art constitutes a space that models the kind of thinking required of the subject of possibility.

The Concept of Utopia

For Adorno, "utopia" designates most often a state or condition that is, at its limit, what we could call "analytically prohibited." That is, it would be a reconciliation of opposed, mutually exclusive states, conditions, or entities. However, we might need to notice here that the opposition, or mutual exclusion, of these states is itself brought about by a kind of thinking. Ideological thinking produces the opposition or mutual exclusion of real entities by concepts, and perpetuates it through and by its operations. This recognition of the 
complicity of thought in the construction of its own delusive context is one of Adorno's emphatic insights. The chance to make thought noncompliant with this delusive context is what makes the truth-seeking effort of philosophy worthwhile.

The problems to which utopia will one day be required to answer, or will need to answer in order to be the promised utopia are not ideal problems. They are problems that reside in concrete material reality rather than in thought alone. Problems like hunger and starvation, disease, homelessness, material deprivations of every sort are not to be resolved in principle or in theory without being addressed in practice, at the level of specific hungry human beings, specific wanderers, specific sufferers. But these material problems will, it seems, ultimately not be resolvable without certain changes in the way people think about all kinds of things, including themselves and the world. The rehabilitation of the thinking subject is a central prerequisite for sustainable utopian imagination. Subjectivity and Its Objective Content One core problem faced by the thinking subject of western philosophy is this subject's enmeshment in the objective world about which it thinks. Every subject is also an object, asserts Adorno. Not every object is a subject; it would presumably be a mistake to impute consciousness, thoughts, to everything. But every subject is also an object. Every subject has a material side, an existential side, a side along which it interacts with objective reality, and which is not equivalent to an interaction of ideas or thoughts. And along this side, the subject comes to know its world in a way, and in ways, that pose a challenge to the subject's mental life.

One implication is that the rational subject of western philosophy, who stands apart from an objective world as an outsider and who 
dispassionately considers that world from an uninvolved vantage point, is a fiction. The thinking subject, whether individual or collective and Adorno disdained the imputation of consciousness to a group as such - being also an object, is caught up in the consideration of the objects of the world and of thought. ${ }^{90}$ In thinking, it is mixed with these objects experientially, shares something of them, is "like" them, although also "unlike" them, in being mediated to itself in different ways. Thought is an activity, but it is not an activity like building a house, in which one proceeds through a series of steps to a predesigned outcome. It is rather more like following a trail towards a destination that is not very well envisioned in advance, a destination which might or might not be clearly recognizable once reached. What the western philosophical tradition has treated as "transcendence" is shadowed by an estrangement from objective reality, born of this very "transcendence." This estrangement is perhaps nowhere better evidenced than in the Kantian treatment of the categories givens for the thinking mind - and the elusive "thing in itself" of the real world, from which, as rational and thinking beings, we are definitively estranged by the workings of our own minds. Adorno finds fault with this Kantian subject, but continues to work within a tradition in which the subject experiences estrangement from objective reality through the mediation of thought, which is a mechanism of estrangement, a substitution of concepts for things in themselves, concepts which perennially fail to become transparent, which abstract from the concrete particularity, and hence individuality and nonsubstitutability of the various concrete conditions and situations in which human beings find themselves and about which they long to arrive

90. On Adorno's rejection of the collective subject, see Buck-Morss, ibid., 28-32, 82-85. 
at understanding. Adorno accepts the core opposition in western

philosophical tradition between presence or immediacy and

understanding. ${ }^{91}$

Understanding is necessarily conceptual; understanding and truth involve an ineluctable quantum of separation of subject and object. Adorno does not hold out the elusive grail of unmediated knowledge in a kind of fusion of subject with object that dissolves the separation between the two in a mystical way. However, he leaves himself open to something very close to this mode of apprehension of objective reality, possibly through the medium of a common recognition of mutual objective, material existence, a common ground of subject and object that permits (mediates) the knowledge and understanding sought. This is the thesis of Lisa Yun Lee, who notes the significance of corporeality and mutuality in Adorno's thought. ${ }^{92}$

A number of Adorno's references to utopia, then, make use of this by-definition-separated or by-definition-opposed concept of subject and object, or of thought and material reality, such that the "utopia" would be reconciliation, would be "to unseal the non-conceptual with concepts, but without making it their equal," would be to achieve a kind of seamless co-presence of thought or philosophical presentation and the body of language in which it is housed. ${ }^{93}$ we might think of this

91. Calling this opposition into question has been one of the central projects of postmodern philosophy, which since Derrida has attacked the opposition from the direction of a belief in a kind of presence that escapes and yet precedes understanding, constituting a privileged access to reality that the mind endeavors to mimic or attain. Rather, it seems from a Derridean vantage point, no such access to a reality unmediated by prior concepts exists at all, so that the alleged opposition between presence and understanding collapses into an opposition between one mode of understanding and another, one elaboration of a discourse of thought and another, with alleged presence supporting a particular appropriation by thought of what is adjudged to be a particular kind of reality. See Jacques Derrida, Speech and Phenomena and other Essays on Husserl's Theory of Signs, trans. David B. Allison (Evanston, IL: Northwestern University Press, 1973).

92. Lee, ibid.

93. Adorno, Negative Dialectics, 10. 
as utopia as the achievement of the debarred desirable, since conceptual thought arises from a desire to understand objective outside, material, non-self - reality, a longing towards what is outside the self, and even to some extent what turns out also be within the self but unknown, overlooked and underappreciated. Utopia represents the accomplishment or satisfaction of that longing.

The Myth of the Constitutive Subject

A second core problem with the position of the subject of thought in the west is this subject's confusion of his or her thoughts with the things about which they are thought. This confusion has been extended in an ideological fashion, as a denial of the content of objects that exceeds their concepts. This denial may take the form of a nominalistic tendency to define a concept by the immediate reality to which it applies but partially, and to deny that an alternative definition or representation of the concept may legitimately govern its use. For instance, we might talk about a society of "free human beings" or a declaration of "human rights," and imagine that the term "freedom" is exhausted by the way it is implicitly defined within liberal democracies, or rather, those societies that go by that name and that can be enumerated in lists of existing polities.

With respect to this problem, utopia takes on the appearance of that state or condition, that social arrangement, in which the truth of key concepts is realized. This realization would be the indictment of all partial identifications, and the vindication of insistence on the full specification of a particular concept. People are fully free in actuality, rather than in some limited way. People are actually happy, when they are happy, and not theoretically or necessarily so. "Knowledge" means what it points to in ordinary usage, not the limited "what passes for knowledge" that we accept as falling under that 
concept in contemporary life as it is organized and lived under more or less authoritarian social arrangements.

Adorno's metaphysical moments stress the breaking-in of happiness, almost shamefully, in the course of life. ${ }^{94}$ These in-breakings forbid the despair that would, in itself, condemn the course of the world to despair. The persistent experience of something that contradicts conclusive despair compels a different conclusion. "All happiness is but a fragment of that complete happiness that men are denied, and denied by themselves." 95 Utopia, which represents the actualized realm of that complete happiness, thus persists in appearing as simultaneously outlandish or foolish, and as possible.

Adorno's repeated references to the "image ban" or the prohibition of mentioning "the name" of God, drawn from his acquaintance with Jewish and Christian religious tradition, should probably also be read in the light of this understanding of utopia and redemption as holding open the possibility of something outside what the extant and historical world dictates as reasonable. Such references abound in Adorno's work, in particular forming the crux of his meditations on metaphysics at the conclusion of Negative Dialectics and arising also in Aesthetic Theory. His explicit references to this iconoclastic monotheistic tradition are what led Jacoby to use Adorno as the paradigmatic "iconoclastic utopian". Perhaps more important in light of the role of utopian conceptualization, however, might be the role of religious symbolism, if not religious organization or practice, in

94. ". . the lighting up of an eye, indeed the feeble tail-wagging of a dog one gave a tidbit it promptly forgets, would make the ideal of nothingness evaporate. A thinking man's true answer to the question whether he is a nihilist would probably be 'Not enough' - out of callousness, perhaps, because of insufficient sympathy with anything that suffers." Adorno, Negative Dialectics, 380 .

95. Adorno, ibid., 404. 
providing the concept of an alternative reality, something not subsumed under the concept of the existential.

Robert Scharlemann has argued that Adorno's refusal of totality, which was consistent with his commitments as a theorist of the Frankfurt School, ruled out a theological consciousness. Adorno's friend and older contemporary Paul Tillich, on the other hand, could develop a systematic theological account of reality precisely because he accepted a concept of totality. ${ }^{96}$ Adorno's insistence on a different and non-totalizing understanding of reality does, however, display aspects of solidarity with theology. Adorno's refusal to conceptualize a totality insists on his perspective that human consciousness, which must respect its own subjective position, is not in a position to perceive or theorize something like a totality, but instead always takes wrong on its understanding of totality. Tillich, a theologian who took Adorno and his ideas seriously, himself acknowledged the demonic force of idolatry. Adorno's adamant refusal to permit the construction of final totalities in his philosophy points in the same rigorously iconoclastic direction. Adorno explicitly refuses every form of dogmatic consolation as a matter of principle. ${ }^{97}$ Nevertheless, his ultimate insistence on "solidarity with metaphysics" proceeds from a commitment that his negative dialectical approach shares with the dogmatic traditions. It may no longer be possible to theorize transcendence in any of the ways the metaphysical tradition has tried; all have proved faulty on his analysis. But the subject of knowledge recognizes, truly, that its "need in thinking" is a need for something

96. Robert P. Scharlemann, "Totality: A Philosophical and Theological Problem Between Tillich and the Frankfurt School," in Laval théologique et philosophique, 47:3 (1991) 329-341, http:id.erudit.org/iderudit/400626er, (accessed January 11, 2010).

97. Adorno, Negative Dialectics, 405. 
like transcendence: the objective reality of something outside that subject and its prior knowledge. ${ }^{98}$

Conceptual Commitment as Utopian Discourse

The line of thinking that secures the need for something that is in solidarity with metaphysical thinking is thought at its most rigorous and abstract. Adorno insists that this form of thought is the prerequisite for a defensible utopian imagination and, even more, any practice that would proceed from that imagination. His persistent defense of the need for philosophy attests to this profound conviction.

What is at stake in philosophy, the effort to grasp and understand reality conceptually, is whether understanding will come to the aid of a suffering humanity or, instead, will perpetuate the domination under which humanity suffers. Adorno's by now famous contention that "the need to give voice to suffering is the condition of all truth" arises in the context of his insistence that philosophy must first of all take as its privileged concern what is most concrete, least conceptual, and then move beyond that. ${ }^{99}$ Philosophy, by its understanding of concrete reality, prepares the indispensable element of "transcendence" or exteriority that might underwrite liberation. So Adorno's argument here makes thought the potential vehicle of its own, and humanity's, possible freedom: "What in thought goes beyond that to which it is bound in its resistance is its freedom. It follows the expressive urge of the subject." 100

An impending and real danger is that thought will abdicate its responsibility to pursue truth. Adorno is not a post-modern thinker. He takes truth seriously, as adequate understanding of the concrete situation in which the thinking subject thinks and acts, and identifies

98. Adorno, ibid., 408.

99. Adorno, ibid, 29.

100. Ibid. 
the quest for truth in that sense with the task of philosophy. Where philosophy seeks to evade the discipline of truth-seeking and truthtelling it succumbs to ideology. Where philosophy succumbs to ideology, thought collaborates with an oppressive reality, representing it to consciousness as an irresistible and alien totality: "the subject as the subject's foe."101 This danger is being realized on all sides, from the false equation of totalitarian statism with revolutionary praxis that Adorno names at the outset of Negative Dialectics to the equally false equation of "what is" with the defensible limit of cognition championed by logical positivism, to the worship of death that founds the jargon of authenticity, to the annihilation of thought in the culture industries' presentation of pure ideology as "thoughtful" and "thought-provoking". Against all of this, philosophy worthy of its calling seeks to "crash through" the "façades" erected by "the status quo. "102

Adorno's arduously cerebral and carefully linguistic philosophy at the same time relentlessly concerns itself with the corporeal and concrete. As he announces in the introduction to Negative Dialectics, the matters of greatest and most urgent interest to philosophy in the late $20^{\text {th }}$ century are "nonconceptuality, individuality, and particularity. . [a] matter of urgency to the concept would be what it fails to cover. . ." 103 It is precisely for this reason that the goal of philosophy, the "cognitive utopia" is "to use concepts to unseal the nonconceptual with concepts, without making it their equal."104

The reflection that will furnish philosophy with the critique it urgently requires depends upon its original and ultimate connection to

101. Ibid., 22.

102. Ibid., 29.

103. Ibid., 8.

104. Ibid., 10. 
the body and bodily human life. Utopia will be a recovery of a valid and acknowledged physical, corporeal human life, human life lived in the body; its precondition is a way of thinking that prepares for a way of life that does not depend on the domination of nature. Such a way of thinking will constitute a significant departure from the operation of the instrumental reason analyzed in Dialectic of Enlightenment, and also from the totalizing dialectical reason of which Negative Dialectics is the critique. In the end, Adorno's famous abstraction and uncompromising intellectualism serves an understanding of subjective Iife that is indissolubly tied to its bodily experience, and to its desire for the satisfaction of that experience. ${ }^{105}$ Another way to say this is that "the emancipation of the subject depends on its capacity to emancipate its object," including the object that constitutes the subject's very body. ${ }^{106}$

\section{Textual Form as Utopian Discursive Practice}

Texts are bodies. ${ }^{107}$ The form of Adorno's texts embodies the utopian aspiration deeply embedded in Adorno's work. With respect to Adorno's utopian discourse, three elements of his textual practice require particular note: the use of "paratactical" textual practice, which is most fully realized in Aesthetic Theory; the use of precise, and for that reason sometimes inaccessible, language, dictated by the principle of the subject matter; and the use of anti-systemic forms, a tactic discussed most fully in "The Essay as Form." These three practices

105. See in particular Lee, ibid., on Adorno's commitment to the integrity of embodied experience.

106. Robert Hullot-Kentor, "Translator's Introduction," in Adorno, Aesthetic Theory, xiii.

107. "The vilification of Cicero and even Hegel's aversion to Diderot bear witness to the resentment of those whom the trials of life have robbed of the freedom to stand tall, and who regard the body of language as sinful." Adorno, Negative Dialectics, 56, italics added. 
constitute different formal aspects of utopian aspiration, according to interpretations provided by Adorno himself in his texts.

Adorno makes clear in more than one text that the form of the philosophical text matters, not least for conveying its content. Adorno comments extensively on matters of presentation and rhetoric, as witnessed by his inclusion of sections on language in the introduction to Negative Dialectics and the text of The Jargon of Authenticity. Jargon itself was to have formed a section of Negative Dialectics, but in its growth according to its own concept outgrew its space in that work, and came to require its own housing. There, Adorno reflects at length on a rhetorical strategy that produces a simultaneously reverent and dismissive use of language to encourage the treatment of the most conditioned form of experience as the most primal and unconditioned. ${ }^{108} \mathrm{~A}$ fragment of Minima Moralia includes cogent reflections on the preparation of texts that pertain to Adorno's specific textual practice. One paragraph in particular from this reflection, "Memento," is worth quoting at length.

Properly written texts are like spiders' webs: tight, concentric, transparent, well-spun and firm. They draw into themselves all the creatures of the air. Metaphors flitting hastily through them become their nourishing prey. Subject matter comes winging towards them. The soundness of a conception can be judged by whether it causes one quotation to summon another. Where thought has opened up one cell of reality, it should, without violence by the subject, penetrate the next. It proves its relation to the object as soon as other objects crystallize around it. In the light that it casts on its chosen substance, others begin to glow. ${ }^{109}$

The metaphor of the spider's web leaves the reader in some doubt as to the identity of the spider, whether the author or the subject matter itself. The indication that it might be the author, the philosopher, gains some support from a related fragment, in which the text is

108. Theodor W. Adorno, The Jargon of Authenticity, translated by Knut Tarnowski and Frederic Will (London: Routledge Classics, 2003).

109. Adorno, Minima Moralia, 87. 
likened to a house full of furniture, in which the author seeks to dwell. Nevertheless, it is clear that the text-web also emanates from the central constellation of ideas itself, and constitutes its expression or unfolding; elsewhere, Adorno insists that "the presentation of philosophy is not an external matter of indifference to it but immanent to its idea." 110 The spider's construction of its web, the philosopher's construction of a text, develop according to a rigorous, stringent instinct-like discipline responsive to the content itself.

Robert Hullot-Kentor has identified this arachnid form of Adorno's posthumously published Aesthetic Theory as just such a "paratactical" text. ${ }^{111}$ His discussion of the differences between his own recent translation of that work and its earlier appearance in English call attention to the significance of the paratactical form in relation to the more conventional, and presumably marketable, outline form. An outline, visible as chapters, headings, and helpfully short paragraphs, advertises a linear, progressive argument, and a systematic thrust. That strategy is disavowed, for better and worse, in the paratactic form. The paratactic form moves from one point to another in strict parallel with transitions and shifts in its object of analysis, repeating itself throughout. The form denies externally imposed system while affirming internal dynamics. With respect to the maintenance of customary relations of space and time, a paratactical text produces "a constantly looming sense of being caught in a vortex" due to its repetition, and both posits and impedes the recognition of the "virtual presence of the whole of the text at any one point."112 In that sense, it enacts both the immanence, and the blockage, of the feasible and

110. Ibid., 18.

111. Hullot-Kentor, ibid., xiv-xix.

112. Ibid., xvil-xviii. 
effectively denied utopia latent in the society that produced modern art.

Such paratactical texts, of which Negative Dialectics is also an example, perform the refusal of a philosophical system that would impose a false identity between an object of investigation and the philosophical concept through which it is investigated and understood, an identity that can in the end only be imposed illegitimately and prior to investigation. That false identity constitutes a potent weapon of ideology, and discourages the attentive engagement of subjectivity and objectivity from which utopic practice might be expected to arise. The paratactical form takes on, in the context of Adorno's work, yet another implicit invitation to the cultivation of utopian consciousness. Adorno's merely mortal readers might well exclaim that, if this is utopia, the easy dystopia feels preferable. The reaction arises all the more since the fibers of Adorno's texts are the difficult formulations of "precise" rather than "cliché" language. As he notes, "A writer will find that the more precisely, conscientiously, appropriately he expresses himself, the more obscure the literary result is thought . . ." since "[r]igorous formulation demands unequivocal comprehension, conceptual effort, to which people are deliberately disencouraged . . ." and only "consider understandable" what is readily accessible, whether or not it communicates precisely. ${ }^{113}$ He derides the tendency to rely on stereotyped phrasing, going as far as to caution against the overuse of the conjunction "but" in a dialectical text. ${ }^{114}$ And he insists on the need for patient, thoughtful selection of vocabulary, attentive to the ravages wrought by recent history on the meaning of words, and asserting that "the writer must combine the

\footnotetext{
113. Adorno, Minima Moralia, 101.
}

114. Ibid., 85 . 
tightest control in ensuring that the word refers, without sidelong glances, to the matter alone . . .115 This principled use of language accompanies his philosophical insight that the concept itself, which comes to material expression in language as nowhere else, is the terrain on which whatever reconcilement between thought and its other, the desire for which is Adorno's paradigm for utopian longing, is to be negotiated.

What Adorno avoids on all accounts, as philosophically unwarranted, is systematic, linear and hierarchical textual presentation. In "The Essay as Form," he argues that essayistic effort of thought, which is preeminently anti-systemic, may be the home of philosophy in the contemporary period. Indeed, it constitutes a utopic practice. Criticism of the essay as "fragmentary and random" stems from a view that, illegitimately, presupposes the identity of subject and object which Adorno's philosophy constantly challenges, and which the essay's form denies. Moreover, the essay's preoccupation with "transitory" matters is another mark in its favor: "it points to that utopia which is blocked out by the classification of the world into the eternal and the transitory."116 [emphasis added]

The "traditional idea of truth" opposed by the essay is the idea that what is can be expressed correctly in a formula, statement, narrative, intellectual system of concepts. In their correspondence, clarity, and systematic relationship these statements and concepts are to act as the double of the reality they purport to understand, and the understanding they purport to represent. The logic on which this concept relies purports to make different things identical by means of the form of subject, object, and copula. In the context of "Trying to

115. Ibid., 221.

116. Theodor W. Adorno, "The Essay as Form," in The Adorno Reader, Brian O'Connor editor (London: Blackwell Publishers, 2000) 91-111, 99. 
Understand Endgame," Adorno asserts that Beckett exposes the everpresent absurdity in this logic, by taking it rigorously to its final extreme in Hamm's last absurd insistence upon opening the window precisely because it is pointless to do so. If opening the window is pointless, then it must be opened. Logic.

The alternative would, presumably, be to refashion understanding into a different kind of tool, less analytic-descriptive, more insightful and knowing. Statements that purport to describe always remain outside and divorced from the concrete reality they pride themselves on having captured - always without having captured the essential qualities of concreteness. An alternative would be that "cognitive utopia" that "would be to use concepts to unseal the nonconceptual with concepts, without making it their equal."117 The problem is the incommensurability between conceptual and nonconceptual, and the aim of philosophy in its search for truth, "that the concept can transcend the concept, the preparatory and concluding element, and can thus reach the nonconceptual" is thereby in its inception and nature dialectical, something that must make itself take contradictions seriously. ${ }^{118}$

The utopia "blocked out" by the division of reality into things eternal and things transitory is that utopia in which truth is to be sought in the realm of the transitory. A rejection of that division expresses the specific desire to make that realm of the transitory the eternal realm of truth and life. The essay, according to Adorno, values precisely those aspects of life that higher philosophy typically eschews, in favor of more abstract and general - i.e., livid and lifeless - concepts. Its form functions utopically, as it elevates the

117. Adorno, Negative Dialectics, 10.

118. Ibid., 9 . 
micrological concerns of living authors with concrete things to the level of serious philosophical consideration, and constitutes a textual place where theory and practice almost become one. ${ }^{119}$

Adorno, in sum, identifies the form of philosophical texts as integral to the pursuit of the truth those texts explore and endeavor to present. Philosophical texts whose form, as a precise embodiment of their content, demand the reader's active engagement, are themselves an invitation to a particular kind of practice. The practice of reading such texts is not neutral; it affects the reader. This understanding of the active engagement of the philosopher with the reader through the vehicle of the philosophical text grows out of Adorno's understanding of language. Language, like text, is not neutral; it is deeply enmeshed in the content of what the subject knows. Language is also the indispensable tool that philosophy uses to know what it knows. For that reason, the subject needs to have available to it a language in which it is possible to think the concept of utopia. Adorno's critique of language addresses this issue.

\section{Adorno's Critique of Language}

Adorno shares with $21^{\text {st }}$ century philosophers a keen appreciation for the role of language in the conduct of philosophy. Dialectics means "language as the organon of thought," and locates its hope for breaking through the context of apparent totality in a judicious use of language that aims at "a mutual approximation of thing and expression," that prepares the mutual approximation of thing and the thought that expresses. ${ }^{120}$ Adorno's comments on language are directed with hostility towards contemporaneous developments that would reduce language exclusively to an allegedly communicative consensus, eliminating its

119. Adorno, "The Essay as Form," 99.

120. Ibid., 56 . 
potentially utopic naming function, as well as towards practices that divorce language from the truth represented by content. Both developments can be seen as threats of totalitarian, dystopian, closure of the possibility of thought's rescue of the utopian moment. Adorno's recurrent language about language has as an aim the conservation of that moment.

The threat of totalitarianism in language arises from severing the original link between language and its objective content. History has witnessed a split between the sign function of language and the mimetic function, in which something in language resembles something in the objective world of which it speaks. The split took place long ago, but has become increasingly complete, with the result that scientific use of language views language exclusively as sign, while art (poetry) treats it exclusively as expressive material. Both attitudes jeopardize the potential, still latent in language, to mediate a relationship between thought and thing. ${ }^{121}$ That potential can be activated dialectically in the awareness of language as name and image, and in the accompanying effort of "determinate negation" to read all images including those of names, concepts - "as script," as surfaces with the ability to reveal "their social, historical, and human meaning."122 Such scripts incorporate both truth and falsehood, but in the process of parsing these elements dialectically, even their moments of falsehood can lead on to an understanding of truth.

This description of language owes everything to that of Walter Benjamin in the prologue to The Origin of German Tragic Drama. There, Benjamin distinguishes the communicative from the naming function of language. The figure of Adam in Paradise becomes the prototype for

121. Horkheimer and Adorno, Dialectics of Enlightenment, 10-21. 122. Ibid., 20 . 
language's naming function, which is a mimetic one: "Ideas are displayed, without intention, in the act of naming, and they have to be renewed in philosophical contemplation. In this renewal the primordial mode of apprehending words is restored."123 Philosophy hereby acquires a political task, becoming the struggle over the representation of ideas; it also acquires a potentially transformative one, as it becomes responsible for seeking, and inhabiting, a realm of truth that does not depend simply on popular consensus or appearance.

Adorno does not adopt this perspective uncritically; he charges Benjamin, too, with positing a premature identity between concepts and the things they conceptualize. ${ }^{124}$ Nevertheless, Adorno's recurrent denunciations of nominalism and positivism acquire additional depth in the context of Benjamin's depiction of language. The treatment of language as exclusively the embodiment of ordinary usage, as containing nothing that is "not merely significative," as being by definition a system of signs, and not merely a system of signs, but a system that depends less on individual words than on the system of differences they encode, has already taken on the given and unquestionable character Adorno sought to oppose. ${ }^{125}$ This makes exhortations like "we cannot ignore the perpetual denunciation of rhetoric by nominalists to whom a name bears no resemblance to what it says" all but structurally unintelligible. ${ }^{126}$ That unintelligibility is an index of the reality of the threat Adorno perceived, and which the focus on language in his philosophy opposed. Once again, the threat is that of the dystopian closing off of imaginative possibilities.

123. Benjamin, German Tragic Drama, 37.

124. Adorno, Negative Dialectics, 53.

125. Ibid., 56 .

126. Ibid. 
The problem with nominalism and positivism, which are linked in Adorno's treatment across his various texts, is that they reduce language to the function of describing what may be observed in the extant situation. They rob dialectical reasoning of its hand- and footholds, by eliminating one pole of the situation used by dialectics for its procedure, the pole of the larger meaning of a term. This is a serious problem, in that dialectics is the philosophical method that offers some hope for understanding both the current situation in which philosophy finds itself and locating the possible exits from that situation. Even more serious, however, is the effect of such a view on consciousness. By denying the gap between idea and thing, perceptible in language and its inadequacy, the participation of nature in the life of thought is also denied, and thereby repressed. Nature is apprehended exclusively as something to be dominated; thought is reduced to the consciousness of such a nature. Nothing else appears. The exit - the actual participation of nature and cognition in a common enterprise remains, but it is behind a curtain, and the light is out. The chances that a suffering humanity will find the reconciliation that original conjunction promises dwindle.

A similar concern with closure, and with truth content, animates Adorno's critique of what he labels the jargon of authenticity. In this use of lariguage, with which he charges the German existentialist authors of his day, the link between language and reality is broken in a different way. Language is not limited to describing an empirical situation, but used to point to a special experience that is, in relation to its context, manufactured. "The empirical usability of the sacred ceremonial words makes both the speaker and listener believe in their corporeal presence," which "is delivered ready from the factory, 
a transcendence which is a changeling said to be the lost original."127

It is language used with a hidden intent to deceive and conceal, in the manner of repression, which cannot allow elements of particularly

traumatic content to reach consciousness. The traumatic content

repressed by the jargon of authenticity is the utter loss of meaning in contemporary existence in the late capitalist way of life. It proceeds

by way of reverent depictions of wholesome, homey rituals that no longer really are performed, an exaltation of religiosity without doctrinal content, the deployment of old words as if they contained an immanent meaning immune to history. ${ }^{128}$

In the end, this language is the tool of a philosophy that seeks to link a feeling of depth and ultimate meaning to the utter meaninglessness of death in an irrational cause itself. The jargon "asserts meaning with the gesture of dignity by which Heidegger would like to dress up death."129 This dignified gesture amounts to the signature of the triumph of the enlightened unreason that is the target of the critique of Dialectic of Enlightenment, the reduction of thought to self-preservation. "The worn-out principle of the self-positing of the ego, which proudly holds out in preserving its life at the cost of the others, is given a higher value by means of the death which extinguishes it."130 What begins as a deformation of language ends in the worship of the power that first elicited language, death, but without any consolation other than posturing. ${ }^{131}$ In the end, the problem of the jargon of authenticity is that it attempts to keep alive the experience of dignity in language, a dignity which needs to be seen for the decadence it always contained. "With it goes that humanity which has

127. Adorno, Jargon of Authenticity, 4.

128. Ibid., $7,16,42$.

129. Ibid., 132.

130. Ibid., 134.

131. Ibid., 135. 
its basic nature not in self-reflection but in its difference from a suppressed animality."132

Language errs as much when it seeks to maintain that suppression, in the face of a situation that makes it increasingly impossible to maintain, as when it seeks to reduce thought to the pure reproduction of immediate reality. In neither case is the ideal of self-reflection, as the self-reflection of nature itself, glimpsed or cultivated. But for Adorno, this self-reflection would be the route that might lead towards a utopia worthy of the name. That is, this self-reflection might generate an ultimately messianic light.

As an aside, Adorno's project preserves a peculiar place for and emphasis on the appreciation and use of metaphor. Along with Nietzsche, Adorno recognizes that much of what philosophers take for literal and precise language constitutes "a mobile army metaphors," which, in particular, constitute frozen social relationships. ${ }^{133}$ From Adorno's perspective such language may be frozen in place in ways that block out alternative, creative and potentially freeing cognitions. On the other hand, some metaphors, precisely chosen, can illuminate truths that are obscured by the operations of what conventional philosophy holds as literal language, as his stress on the element of presentation in philosophy, and his own judicious use of vivid metaphors, makes abundantly clear.

\section{The Subject of Utopia}

As we have seen, Adorno deals with the epistemological problem of the relationship of subject to object, and echoes of this problem

132. Ibid., 136.

133. Friedrich Nietzsche "On Truth and Lying in an Extra-Moral Sense," in Friedrich Nietzsche on Rhetoric and Language, edited and translated by Sander L. Gilman, Carole Blair and David J. Parent (New York: Oxford University Press, 1989) 246-257, 250 . 
reverberate throughout his work. ${ }^{134}$ Adorno takes the problem of the relationship of "the subject" to "the object" seriously, making it central to his major works. That may strike post-modern readers, who take the death of the subject as yesterday's news, as quaint. Adorno himself acknowledges the inescapable vagueness of the formulation. ${ }^{135}$ Nevertheless Adorno treats the alienation of the subject of thought, in its thought, from concrete reality as both emblematic and constitutive of the dystopian reality of the late 20 th century. The reversion of enlightenment to myth as a consequence of the subject's ignorance and heedlessness of its domination by nature in the aims of enlightenment itself is but one striking example. In returning to the problem over and over again, his effort to find ways to overcome the problem philosophically constitutes the utopic direction of Adorno's philosophy.

The central dilemma of the subject-object problem is the alienation of the subject from its object or objects. This alienation, captured by the form of the concept as "the wall between thinking and the thought," separates the knower from what the knower knows (as that which is thought, its object). ${ }^{136}$ "The thought" in this context, that miniscule separation, also forms the substrate of domination. It constitutes domination all the more as the subject remains ignorant of its participation in its material object, because of its own status as an object, and because of its own objective material composition.

In his latest statement on the matter, Adorno wrote "If speculation on the state of reconciliation were permitted, neither the undistinguished unity of subject and object nor their antithetical

134. See Buck-Morss, ibid.; Brian O'Connor, Adorno's Negative Dialectic.

135. Theodor Adorno, "Subject and Object," in The Adorno Reader, edited by Brian $O^{\prime}$ Connor (Oxford: Blackwel1, 137-151.

136. Adorno, Negative Dialectics, 15. 
hostility would be conceivable in it;" what would be conceivable, instead, would be "the communication of what was distinguished," that is, the communication of what is distinguished as "subject" and what is distinguished as "object."137 The sentiment echoes images traced as early as Dialectic of Enlightenment, in which the genuine utopia, in contrast to Bacon's patriarchal one of the mastery of nature by mind, involves the synchronous reconcilement in difference of mind with its origin. ${ }^{138}$ This reconcilement "would be the thought of the many as no longer inimical, a thought that is anathema to subjective reason," because of its urge to subject everything to itself. ${ }^{139}$

What emerges from Adorno's treatment of the relationship of subject to object, is that the subject itself may not finally, legitimately, be separated from its individual, particular human subjects, however epistemologically abstract or socially collective an understanding may be demanded during the course of philosophical investigation. These human subjects are the subjects of the utopia, as insufficient as merely individual happiness is to constitute utopia as such. ${ }^{140}$ Adorno's critique of Hegel culminates in his rejection of the immense distance of absolute spirit from its bearers, in which "the subject, the substrate of freedom, is so far detached from live human beings that its freedom in necessity can no longer profit them at all."141 Adorno's allusion to the desirable philosophical condition in which the subject and object of knowledge actually "communicate," in which subject recognizes its own objectivity, and in which the object's participation in conceptualization becomes more transparent, has

137. Adorno, "Subject and Object," 140.

138. Horkheimer and Adorno, ibid., 33.

139. Ibid., 6.

140. Adorno, Negative Dialectics, 353.

141. Ibid., 350 . 
appealed to feminist theorists. ${ }^{142}$ It presents a figure of reciprocity rare in mainstream philosophy. It shares an affinity with Irigaray's understanding of the need to ensure communication across the boundary of sexual difference, and the relationship of that line to the conceptualization of the line between culture and nature, of which more later. And it attests to the centrality of this particular basic structure of thought, in Adorno's philosophical discourse, to the matter of utopia. For Adorno, the distance between society as it is and the utopia that even this society might realistically strive to bring into being, stems from the drive towards domination that finds its earliest and pre-eminent expression in epistemological subjectivity, along with its characteristically instrumental attitude. The achievement of a happy, mutual relationship between thinker, thought, and thought-about, would require the acknowledgement on the part of thought of its own objectivity, or "nature," or "particularity," as well as its own enmeshment in relations of power vis-à-vis nature, its own status as repressed and dominated nature. Such an acknowledgement would be tantamount to the achievement of a form of consciousness with an affinity to class consciousness, based on membership in a large class: the class of social beings dominated by reified mind. Such a consciousness might, if it proceeded thoughtfully, be able to "devote itself to dissolving that power."143 Empirical signs of this devotion are few and fleeting. Adorno's philosophical work seems inclined towards encouraging their appearance.

Paradoxically, the estrangement of subject and object that constitutes the problem also seems to hold the key to its solution, if that solution is ever to be effected. That is, the hope for a

142. Lee, ibid.; Patricia Mills, Feminist Interpretations of Hegel (University Park, PA: Pennsylvania State University Press, 1996). 143. Horkheimer and Adorno, ibid., 34. 
reconcilement lies in a principled refusal to succumb to the delusion of identitarian ideology, to accept any substitute or sham reconcilement, but to hold out for its actuality, even if its actuality is unreachable in its fullness. This task demands of thought, of philosophy, an adamant refusal to work towards pre-scribed systematic solutions, or to impose alien thought forms on its object. A philosophy that would work in the direction of hope must resolutely hold its own concepts, the tools with which it cannot dispense, in perpetual suspicion, leaving them open to dialectical correction by the reality they endeavor to grasp. ${ }^{144}$

\section{Space and Time}

Adorno's utopian enunciations are directed towards preventing a complete totalitarian or identity-thinking closure. They search for the location of some discrepancy, a necessary distance, between conditions as they are and some alternative. The concluding section of Negative Dialectics, the "meditations on metaphysics," proffers "the object of aesthetics" as one such a place. ${ }^{145}$ The place constituted by the aesthetic object is a problematic one. The promises the aesthetic object makes are always over-promises, without the guarantees required by philosophy. Nevertheless, the structure of the aesthetic object, in relation to the structure of the world in which it appears, acts as a

144. This insistence embodies, in capsule form, the appropriate response to Nigel Gibson, who challenges Adorno's reading of Hegel, in particular around the function of the "absolute negative" in Hegel's system, as well as his reading of Marx's theory of alienated labor. The central point of departure for Negative Dialectics, which applies to every conceptual criticism leveled at its thinking, is that "objects do not go into their concepts without leaving a remainder" (5) and that furthering an understanding of the relationship of the subject to that remainder is the vital desideratum. The method of calling attention to Adorno's non-Hegelian-Marxist failure to understand the true meaning of Hegel's and Marx's concepts as challenges to the import of Negative Dialectics misses that point by a wide margin. See Nigel Gibson, "Rethinking an Old Saw: Dialectical Negativity, Utopia, and Negative Dialectic in Adorno's Hegelian Marxism," in Adorno: A Critical Reader, edited by Nigel Gibson and Andrew Rubin (Oxford: Blackwell, 2002) 257-291.

145. Adorno, ibid., 
concrete representative of an alternative to the closed context of immanence that mitigates against utopia.

Adorno is careful to point out how "micrological" the potential of this object, or of any possible metaphysical thought that aims at transcendence, has become. Metaphysical possibility - which remains desirable for a humanity that continues to wish to revoke the suffering that is past as well as redeem the suffering that obtains and cancel whatever suffering might await in future, but the truth of which has become radically questionable - retreats into micrology. ${ }^{146}$ The category of the micrological is probably on loan from Walter Benjamin, and relates as well to his concept of constellations. ${ }^{147}$ It is illustrated in Adorno's metaphysical speculations in two ways. One is with his concluding insistence that the smallest "intramundane traits" are the stuff of metaphysics, suggesting a focus on the most particular as the pre-eminently suggestive of something irreducible to identity thinking. ${ }^{148}$ The other is his striking statement that small representational discrepancies make themselves disproportionately significant, as in the discrepancy between "death" and "rest" that constitutes the "haven of hope, the no-man's land between the border posts of being and nothingness" that serves as a metaphor for the possibility of utopic space. ${ }^{149}$

A no-man's land is the opposite of a romantic place removed from day-to-day conflicts. In war, a literal no-man's land is by definition

146. Ibid., 407-408.

147. According to Giorgio Agamben in The Coming Commity, Walter Benjamin was fond of a tale about the world to come in which "everything will be just as it is now, just a little different." Agamben, The Coming Community, 53. Novalis, in The Universal Sketchbook, repeats the same story with a slight variation: "In the world to come everything will be as it was in the former world - and yet it will be altogether different. The world to come is rational chaos - the Chaos that has permeated itself - that is inside and outside itself - Chaos ${ }^{2}$ or o" See David Farell Krell, "Two Apothecaries: Novalis and Derrida," Studies in Romanticism 46:3 (Summer, 2007) 289-309, 301.

148. Adorno, ibid., 407.

149. Ibid., 381. 
a contested space, fraught with lethal possibilities. In peace, it is marginalized and excluded, less a place that supports life than a place that testifies to its withdrawal. A conventional metaphorical use of the term emphasizes its undecidable and precarious character. ${ }^{150}$ But precisely because it constitutes a place that cannot be definitively claimed for one side or the other, and because it belies the identity of socially- and politically-imposed boundaries on something that continues to exceed and underlie them, it constitutes the "neutral" territory that is always, as Louis Marin insists, the classic structure of utopia. ${ }^{151}$ Despite its empty appearance, no-man's land has the right address.

The hope associated with this no-man's land, as also with the object of aesthetics, is less directly spatial than it is temporal. It is the hope that something might yet happen, or rather, be made to happen. It is inseparable from the refusal of "absolute conclusiveness" in history that is the temporal consequence of the negative dialectical approach. ${ }^{152}$ The stubborn refusal of history, or something like history, to come to an end constitutes the temporal horizon of a utopian hope, though not of expectation. The possibility that something un-natural, un-conditioned might yet arise in the still-moving historical space or place is too small to label hope, but not too small to link to the micrology of a thought that would affirm its solidarity with metaphysics. What an ontological philosophy would exempt from history, dialectics locates within it, making history itself a place, where something worthy of the name of metaphysics, the philosophy of something beyond the immediate and dystopian context of everyday life,

150. "An area of human activity characterized by ambiguity, uncertainty, or peril." Funk \& Wagnall's Standard College Dictionary (New York: Harcourt, Brace and World, 1966).

151. Marin, ibid.

152. Adorno, ibid., 403. 
"may originate only with the realization of what has been thought in its sign."153 The failure of human beings simply to be what they are and always have been, to go into their concept without a remainder, remains the source, micrological as it is, of whatever possibility of utopic practice, or creation, might be anticipated from Adorno's analysis.

If hope is prohibited, as if its enunciation would be idolatrous, despair is prohibited all the more, particularly in the context of a history that still provides the concept of an outside, as the concept of "not yet." Despair, too, is tantamount to idolatry: it fallaciously ". . guarantees to us that the hopelessly missed things exist . . .", though they are not of this world. ${ }^{154}$ This treatment of despair should remind us of Agamben's analysis of the medievalists' acedia, embodied in Dürer's etching of the angel looking motionlessly into the distance, surrounded by forsaken tools. ${ }^{155}$ That image itself encodes an indispensable element of contemplation, and attachment to the image of what is contemplated. Its specific error in Adorno's context would lie in its attachment to a prematurely-closed form. The inability to act associated with acedia would be inseparable from the inability to relinquish the beloved image for an activity promising more substantive content, but without any guarantee of its ultimate form. "If rescue is the inmost impulse of any man's [sic] spirit, there is no hope but unreserved surrender: of that which is to be rescued as well as of the hopeful spirit."156

But if a rescue of the self along with the hope for it must be abandoned, the persistence of truth "along with its temporal core"

153. Ibid., 404 .

154. Ibid., 372 .

155. Giorgio Agamben, Stanzas: Word and Phantasm in Western Culture, translated by Ronald L. Martinez (Minneapolis: University of Minnesota Press, 1993).

156. Adorno, ibid., 392. 
continues to open up a place that travels along with the course of history. ${ }^{157}$ That place constitutes its ever-present, promising and as-yet dissatisfied companion. It cannot be the "homogeneous, empty time" of the Social Democratic illusion of progress derided by Walter Benjamin, although whether Adorno's dialectical time contains the messianic "Jetztzeit" described by Benjamin is not entirely certain. ${ }^{158}$ If it does, it will be because "a legible constellation of things in being" had been read in such a way that its "elements unite to form a script" a script unlike that of the administered world with its repetitive prescribed relations and outcomes, both in the truth of its content and the fidelity of its form. ${ }^{159}$ The task of noticing, reading, copying, and distributing that script seems to belong to philosophy. Saying so constitutes the recurrent theme of Adorno's utopian discourse.

\section{Adorno's Reader as a Subject of Possibility}

In short, while utopia is not often the explicit topic of Adorno's philosophical texts, the possibility of utopian imagination is a constant concern of his philosophical work. Adorno persistently addresses his reader as a subject trying to know, and in particular, trying to know how to respond to the suffering that subject encounters in herself and her world. Adorno's address incorporates a recurrent critical moment that depicts the reader's context as one of deeply dystopian urgency, which it is the philosopher's task to display, and the reader's task to grasp and see clearly. The analysis of that situation, and of its underlying causes, comes in the form of texts that cannot be read and understood without adopting a significantly modified point of view, an altered subjective state. The language of

157. Ibid., 371 .

158. Walter Benjamin, "Theses on the Philosophy of History," in Illuminations, edited and with an introduction by Hannah Arendt (New York: Schocken Books, 1978) 261.

159. Adorno, ibid., 407. 
those texts is self-consciously language that permits, and in places encourages, something like metaphysical experience. This use of language stands in contrast to the superficially self-effacing operation of conventional or nominalistic language on one hand, and in contrast to the self-consciously mystical pretensions of "authentic" language on the other.

The subject of philosophical inquiry, insofar as that subject is a reader of Adorno's philosophy, hereby becomes a site of the discrepancy between concepts and their objects in the struggle to come to an adequate appreciation of those texts and that language. This state of discrepancy is a state of possibility. The subject of that state is a subject in a better position to cultivate the need in thinking in the direction of truth, one condition of which for Adorno is, as already noted, the "effort to give a voice to suffering."

That some of that suffering is the direct effect of the philosophical task, properly pursued, reflects the relationship of philosophy to truth, and the relationship of truth to its world. Only in a happy world could philosophy honestly be a gay science. The double reflection that philosophy must undertake is negative on both hands. On one, it must enter the confrontation with "consummate negativity" which "once squarely faced, delineates the mirror-image of its opposite."160 On the other, it must pursue the "redemption of illusion" in the knowledge of art. For Adorno, this second reflection is potentially restorative. "What spirit requires of subjective spirit is that spirit's own spontaneity. The knowledge of art means to render objectified spirit once again fluid through the medium of reflection."161 In the fantastic fluidity of that reflected light, a micrological possibility might be

160. Adorno, Minima Moralia, 247.

161. Adorno, Aesthetic Theory, 357. 
realized: that of an active thought which, in affirming its solidarity with metaphysics, is reminiscent of something messianic, without mentioning its name. 


\section{CHAPTER III}

\section{RADIATION}

Luce Irigaray has spent a lifetime pointing out the incomparable metaphysical relevance of sexual difference. The history of western thought makes it possible to recognize the object of aesthetics as the trace of an enigmatic other who has synthesized and reflected material and social reality in a complex way under the press of an impulse to create a better reality. The history of that same thought makes it possible to recognize woman as nature. That demonstrates that the tremendous energy and illumination that could radiate from sexual difference - energies that could power the discovery of "worlds more fecund than any known to date" - have not only not been addressed, they have not even been sensed. "Sexual difference is probably the issue in our time which could be our 'salvation' if we thought it through."1 Irigaray's work as one of the controversial "French feminists" has by now spanned several prolific decades. Like Adorno, her work touches a wide range of concerns, from linguistics through psychoanalysis to philosophy. She is a practicing psychoanalyst who has expressed explicit appreciation for the psychoanalytic tradition and its therapeutic possibilities. She is a practitioner of religious traditions, in particular meditation based on Hinduism. She has engaged in political activity, notably through her work with the Italian

1. Luce Irigaray, An Ethics of Sexual Difference, trans. by Carolyn Burke and Gillian C. Gill (Ithaca: Cornell University Press, 1993), 5. 
communist party. She is also, when the opportunity presents itself, an educator. ${ }^{2}$

Her work also demonstrates a similarly wide range of influences. It engages central theoretical insights of psychoanalysis, with which she takes issue but which she also appropriates at significant junctures. It draws on linguistics, including Irigaray's own original research in this area. And it famously displays the fruit of her "fling with the philosophers," from Plato through Levinas and Derrida. ${ }^{3}$ Nietzsche and Heidegger in particular have become the conversation partners of fulllength dedicated philosophical treatments in Irigaray's characteristic mimetic style. ${ }^{4}$ In comparison with the depth and breadth of the influences and import of her work, the focus of this chapter, which devotes most of its attention to three of Irigaray's recent texts, seems narrow.

Irigaray's reputation as a controversial theorist grew following the publication of Speculum de l'autre femme (Speculum of the Other Woman), an event to which she also owed her dismissal from the University of Vincennes. In that work, she stated that she was working to develop the appropriate objective context for an investigation of feminine subjectivity, a topic which has formed her perennial interest. Irigaray's early work remains integral to her larger intellectual objectives. Nevertheless, this chapter focuses attention on three more recent works, I love to you (J'aime à toi), The Way of Love (La Voie de l'amour), and Sharing the World. These texts include both the critical and utopian elements identified by Margaret Whitford in her analysis of

2. Luce Irigaray, Teaching, ed. by Luce Irigaray with Mary Green (New York: Continuum, 2008).

3. Irigaray, This Sex, 150 .

4. See Luce Irigaray, Marine Lover of Friedrich Nietzsche, trans. Gillian C.

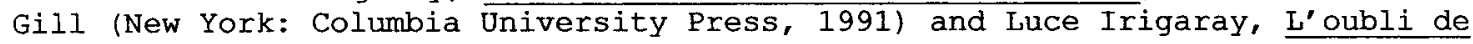
L'air Chez Martin Heidegger (Paris: Editions de Minuit, 1983). 
Irigaray's early writings, but lean more heavily toward the utopian than the critical side. ${ }^{5}$ The focus on these texts in particular permits discussion both of Irigaray's interactions with Hegel, which are most on display in I Love to You, and her interactions with the Heidegger of "On the Way to Language" and "Building, Dwelling, Thinking" which are explicit in the construction of The Way of Love and Sharing the World. Irigaray may be best known for the frequent label of "essentialism" that has accompanied her indefatigable emphasis on sexual difference. In spite of an alleged dissipation of the essentialism-antiessentialism tensions associated with discussion of Irigaray's work in recent years, this theme remains one of the most accessible handles by which Irigaray's work is grasped in casual conversation. ${ }^{6}$ Since the question of sexual difference colors the chapter that follows, the question about essentialism poses itself accordingly. But the emphasis here will fall to a much greater degree on the way Irigaray deploys language of sexual difference as she interacts with Heidegger on the development of language and its role in the generation of culture. That is, the emphasis is on her effort to develop a paradigm of conversation between two. This effort goes beyond the paradigm of "amorous exchange" to which Margaret Whitford's analysis points, extending that exchange to include interactions that are something different from what is commonly called "amorous," although no less cognizant of sexual difference. This exchange still takes place along a way Irigaray characterizes with the word "love," the way of which she describes as

5. Whitford, Philosophy in the Feminine.

6. Alison Stone, "The Sex of Nature: A Reinterpretation of Irigary's Metaphysics and Political Thought," Hypatia 18:3 (Autumn, 2003) 60-84. 
illuminated with a light that radiates from and returns to an intimate source. ${ }^{7}$

The chapter glances at the objectives of Irigaray's work as a whole, and then proceeds to consider her use of utopian themes, primarily as they appear in three recent works: I love to you, The Way of Love, and Sharing the World. Then, it considers how Irigaray's use of utopian elements incorporates the devices also seen in Adorno, in particular the emphasis on textual practice, a dedicated treatment of a form of the subject-object relation, an emphasis on the problem of language, and her specific treatment of space and time and their transformative possibilities. Overall, it argues that Irigaray responds to what she identifies as the foreclosure of properly feminine subjectivity, which has so far barred the coming-into-existence of what she designates as "Woman-as-Subject," by addressing and discursively constructing "Woman" as a subject of utopian possibility in a world that has not yet realized the transformative possibilities implicit in sexual difference. Because sexual difference both characterizes the material world, and has as yet not been recognized in the construction of the cultural world, the unrecognized possibilities of sexual difference radiate a messianic light.

\section{Dystopian Repression and Response}

It has not been easy for Irigaray's readers to understand what she is trying to do. It has not even always been clear that she had a philosophical project. The first serious interpreter of Irigaray as a philosopher, Margaret Whitford, acknowledged "it has taken me a long time to understand her" while also concluding that Irigaray is "committed to 'the work of the universal' and to the centrality of

7. Luce Irigaray, The Way of Love, trans. Heidi Bostic and Stephen Pluhacek (London: Continuum, 2002), 174. 
ethics." Whitford summarizes Irigaray's overall project as the effort "to intervene as a woman. . . in the discourse of philosophy". ${ }^{8}$ Judith Butler has explicitly discussed her initially dismissive response to Irigaray's approach, only later to realize that her project involved "this strange practice of reading, one in which she was reading texts that she was not authorized to read, . . and that she would read them anyway." Such a project was clearly "a feminist critical practice" with some edifying potential. ${ }^{9}$

Irigaray herself, in an answer to a question about the status of her text Speculum, described herself as

. . trying, as I have already indicated, to go back through the masculine imaginary, to interpret the way it has reduced us to silence, to muteness or mimicry, and I am attempting, from that starting-point and at the same time, to (re)discover a possible space for the feminine imaginary. ${ }^{10}$

Irigaray's statement indicates her use of the three-fold Lacanian division of the objective world into real, imaginary and symbolic. That acceptance places Irigaray, as we have already noted, within a project that draws on the psychoanalytic tradition, taking Freudian and Lacanian categories seriously while also taking issue with them. Her use of, and ambivalent loyalty to, the intellectual framework of psychoanalysis, specifically Lacanian psychoanalysis, testifies to the persistently therapeutic dimension of her work, which manifests itself in her textual as well as her psychoanalytic practice.

Although she emphasizes the impact of her work on the "imaginary," her work also addresses the "symbolic" register. Irigaray has been described as being "invested in rewriting the symbolic as a way of

8. Whitford, Philosophy in the Feminine, 4, 13. Whitford's use of "the universal" indicates a human concern not restricted to the interest of a single gender.

9. Cheah, Grosz, Butler, and Cornell, ibid., 19.

10. Irigaray, This Sex, 162-3. Note that in this statement, "us" may or may not be read as referring to "women". 
changing the social and political situation of women and initiating a culture of sexual difference."11 Elsewhere, she labels the phallic, which marks the boundary for Lacan between the imaginary and the symbolic, "tantamount to the seriousness of meaning," something her project contests. In particular, and in a reversal of Adorno's explicit objective of securing the conditions of possibility for the thought of "truth," understood as a giving voice to suffering, Irigaray says the "speaking of truth constitutes the prohibition on woman's pleasure, and thus on the sexual relation."12

Irigaray's refusal of "truth" here does not indicate either a contempt for honesty, nor her determined opposition to the objectives advanced by Adorno. Adorno's use of the word "truth" indicates a desire to go beyond the constraints imposed by its conventional association with the adequacy of language. Irigaray's use of the word "truth" in this context refers precisely to the way those constraints themselves are made absolute and binding on the users of language. Adorno develops a standard of truth that seeks to dislodge a premature identification or adequation of concept and presumed object of conceptualization, finding in that identification an illegitimate closure and denial of remainders and non-identities. Similarly, Irigaray struggles here to express a consciousness of the radical excess of objective and concrete reality with respect to the language and conceptual apparatus available for expressing its intellection. The "truth" Irigaray opposes in this context, then, amounts to what Adorno opposes, on similar grounds, as "identity thinking."

It might be more precise to identify the objectives on which Irigaray's work converges as avoiding the articulation of a new

11. Krzysztof Ziarek, "Proximities: Irigaray and Heideger on Difference," Continental Philosophy Review 33:2 (April, 2000), 133-158, 134 .

12. Irigaray, This Sex, 163; italics in original. 
symbolic, which would presumably replace the current phallogocentric one. A single, unitary symbolic will not resolve the problem she perceives and struggles to bring to her readers' awareness. For Irigaray, the one symbolic within which humanity now operates, which represses both the characteristic meanings of the feminine and the masculine, is problematic because it excludes recognition of the intrinsic sexual differentiation of the human. The inability to accept and cultivate difference then makes impossible a cultivation of the internally-differentiated human, and a passage from nature to culture, that draws on the full range of human possibilities. For Irigaray, "culture" as something authentically human has not yet emerged in human life; "culture" as something other than what is opposed to a "nature" equated with a "feminine" that has been constructed by the exclusion of the possibility of a feminine subjectivity is something that human beings have yet to begin to create.

In spite of their shared opposition to forms of "identity thinking," Irigaray's philosophical objectives differ significantly from Adorno's. Her efforts focus consistently on the role of sexual difference and sexuate possibilities as the source of something like metaphysical experience. Where Adorno sees a micrological and fugitive site of discrepancy, Irigaray detects a vast, unexplored territory with the riches to create an alternative to the language and syntax of "truth" that suppresses women's reality, sexual pleașure, the sexual relation, and the cultivation of human culture on the basis of human nature in its fullness. Irigaray pursues this quest for the objective conditions of a changed form of thinking and communication that would include a revised human subjectivity, a human subjectivity that would be internally diverse, in something like dialogue with the philosophers of the western philosophical tradition, but in particular with Plato, 
Levinas, and Heidegger. The rehabilitation of psychoanalytic constructs, the rethinking of the unconscious, and its relation to language, remains a significant part of her work.

One way to present Irigaray's efforts might be to say that she psychoanalyzes the philosophers, while interrogating the philosophical presuppositions and implications of psychoanalysis. As she says in response to a question about her use of Freudian theory, whatever "challenge" her critique offers is not designed to "return to a precritical attitude toward psychoanalysis" or to deny its therapeutic effectiveness, but to show that "if Freudian theory indeed contributes what is needed to upset the philosophic order of discourse, the theory remains paradoxically subject to that discourse where the definition of sexual difference is concerned."13 She poses over and over again the question of how to retain the insights of psychoanalysis that promote a liberating understanding of human subjectivity, while opening the repressive structure of the psychoanalytic system to its excluded content.

One element of this project has been a conscious reconstruction and creation of scenes of origin that recognize sexually differentiated subject positions. An example here is Irigaray's insistence on the importance of the mother-daughter relation. ${ }^{14}$ Such scenes of origin offer a contrast to the single oedipal scene offered by traditional psychoanalytic narrative, through which a non-sexually-differentiated humanity passes to produce, according to the classic account, a humanity distinguished as Same and Other-of-the-Same. Irigaray's appreciative but critical engagement with Freud and Lacan impels her to search for ways to intervene in practices of thought that become

13. Irigaray, This Sex, 72 .

14. See "Love of Same, Love of Other" in Irigaray, Ethics of Sexual Difference, $97-115$. 
embodied in congealed spirit prior to consciousness and language. ${ }^{15}$ That recognition suggests that at least one aspect of Irigaray's work is therapeutic, a kind of couples counseling for the western cultural relationship.

At the same time, the psychoanalytic framework itself requires intervention, as indicated by Irigaray's lengthy critique of its philosophical presuppositions in Speculum. A corresponding element of Irigaray's project is the renovation of psychoanalysis to open up the space for the articulation of a subjectivity excluded by the terms of the system of subjects and subjectivities. In this work, Irigaray both draws on Lacan, for a non-humanist, psychoanalytic account of the human subject and its incomplete constitution by reason and consciousness, and deconstructs Lacanian discourse by questioning the unconscious identification of the unconscious with woman or women by virtue of women's enforced silence. Women, who have not been allowed to speak for themselves within the space of theory, and who have often been prevented from vocally entering the places of general human discourse, become identified with the unconscious in the official and even the Lacanian psychoanalytic account. Another aspect of Irigaray's project involves the restoration of a voice to women as subjects - even if, as Grosz suggests, it requires the mime of a hysterical voice to effect that reinsertion of voice. ${ }^{16}$

Philosophically, Irigaray engages with a long list of western philosophers, from Plato and Aristotle through Deleuze and Levinas. However, as Patricia Huntington notes, "Twentieth-century Continental philosophy proceeds by way of a love-hate affair with Heidegger," and Irigaray's participation in that ménage is evident from her earliest

15. Luce Irigaray, Sharing the World (New York: Continuum, 2008) xii.

16. Grosz, Lacan: A Feminist Introduction. 
work, as in her acceptance of Heidegger's adage that "each age has one issue to think through, and one only." ${ }^{17}$ One of her texts, L'Oubli de $\underline{I^{\prime} \text { air chez Martin Heidegger, }}$ is dedicated to a close reading and mimetic treatment of Heidegger's philosophy. Her two most recent works, The Way of Love and Sharing the World, both explicitly depart from Heidegger's "On the Way to Language," with substantial considerations of "Building, Dwelling, Thinking" and "The Question Concerning . Technology."18 Irigaray sometimes refers to Heidegger as "the philosopher," ironically casting herself in the role of Thomas Aquinas vis-à-vis Aristotle, and leaving her readers to wonder who occupies the position of Augustine. Nevertheless, as she makes clear in her introduction to Sharing the World, she finds the philosopher's stance wanting, and dangerously so. A chronic preoccupation with the same, a fixation on a single subject to the exclusion of other subjects, and a consequent failure to allow others to exist as others deforms his ontology. That approach requires others to be integrated into a "shared" world that is less a "shared" world than it is commonly or even imperialistically imposed on all its subjects, without regard for their differing subjectivities. ${ }^{19}$ Irigaray's ongoing engagement with Heidegger needs to be understood as the struggle to rehabilitate and rearchitect a framework for co-habitation of a world; for a kind of "building, dwelling, and thinking" together that has yet to acquire its proper ground.

Irigaray's commentators repeatedly identify her project as utopian. As part of this utopianism, Irigaray develops a "new poetics" of

17. Irigaray, Ethics of Sexual Difference, 5.

18. Irigaray, L'Oubli de l'air chez Martin; Irigaray, The way of Love; Irigaray, Sharing the World. For discussions of Irigaray's relationship to Heidegger, see especially Chanter, Ethics of Eros; Huntington, Ecstatic Subjects; Krzysztof Ziarek, ibid.

19. Irigaray, sharing the world, 136. 
indispensable utopian imagination. This explicitly poetic dimension of her work involves her work in aesthetics, without constituting a distinct, fully developed aesthetic theory. ${ }^{20}$ Her work has inspired artists, and in particular architects, for this reason. ${ }^{21}$ Similarly, while not a theologian, her work incorporates an extensive and often favorable treatment of religious themes. She takes seriously a need for religious symbols of the feminine as an aspect of the effort to construct a feminine imaginary, and has given classic religious texts, in particular the texts of female mystics, extended consideration. ${ }^{22}$

\section{Utopia in Irigaray's Work}

Since Margaret Whitford's early, careful analysis of Irigaray's early important texts, scholars have recognized that a particular utopian vision plays a profound role in Irigaray's work as a whole. Whitford assigned Irigaray to the visionary utopian "strand" of 1970s and 80 s feminist theory. Irigaray does not offer a detailed "blueprint" vision of utopia, she does not quite fit Jacoby's model, either. Whitford sees her "myths and utopias" presented as evocative glimpses throughout her work as "attempts to construct new fictions" that promote change in a world that requires transformation. ${ }^{23}$

\section{A Utopian Ethical Vision}

Irigaray's utopian direction is perhaps most explicitly on display throughout the text of An Ethics of Sexual Difference. This text assembles lectures given at Erasmus University in Rotterdam in 1982, under the title "The Ethics of the Passions." Both the location and the

20. Irigaray, Ethics of Sexual Difference, 5; Whitford, Philosophy in the Eeminine; Huntington, Ecstatic Subjects; Drucilla Cornell, Transformations: Recollective Imagination and Sexual Difference (New York: Routledge, 1993); Ewa Plonowska Ziarek, Ethics of Dissensus; Hilary Robinson, Reading Art, Reading Irigaray: The Politics of Art by Women (London: I.B. Tauris, 2006).

21. Robinson, ibid.; Peg Rawes, Irigaray for Architects (New York: Routledge, 2007).

22. Of particular note is the section of Speculum titled "La Mystérique," an extended reading of texts of feminine mystics.

23. Whitford, Philosophy in the Feminine, 19, 170. 
rubric of the lectures seems significant with respect to the text's explicit utopianism. Erasmus was the designated recipient of Thomas More's text of Utopia. The "passions" are etymologically those experiences humans suffer, and in Irigaray's treatment, even such seemingly positive experiences as wonder and joy are shown to entail their share of suffering. These lectures can be read as an extended utopian reflection constructed around the utopian space opened and created by a "sensible transcendental" of which "we would be the mediators and bridges." 24

Irigaray"s concept of a "sensible transcendental" attaches to what she identifies as a tangible site for something like metaphysical experience. The experience of a discernible difference, like that of sexual difference, across which people can discern unknown but communicable otherness, combines the paradigmatic elements of the experiential and the transcendent. Her address makes her readers responsible for developing the forms of revelation called for by this communion, casting them in the role of the recipients, or even enunciators, of the word from beyond. In this sense, her writing addresses a prophetic subject of possibility who speaks on behalf of a not-yet subject.

The reflection that constitutes Ethics of Sexual Difference begins with the announcement of a "horizon of worlds more fecund than any known to date" implicit in thinking through the philosophical issue of sexual difference. That reference brings to mind the polarity of old and New Worlds which More's utopia neutralized. It concludes with her elaboration of the indispensable contribution of "flesh" to a creative and radically unsubstitutable touch in the context of "The Fecundity of the Caress," a touch which lies "on the horizon of a story" that

24. Irigaray, Ethics of Sexual Difference, 129. 
precedes the subject, and in which she describes pleasure itself as an architectural material. ${ }^{25}$ The journey from horizon to horizon takes the reader on a whirlwind tour of western philosophy, from Plato's Symposium through Descartes and Spinoza to Hegel, Heidegger, and Merleau-Ponty.

What is at stake in the world that might yet be glimpsed by thinking through the philosophical issue of sexual difference is precisely the "horizon" of "a world for women" which has not yet been built. The basic conditions, of language, thought, and political economy, for developing a recognition of the transcendent possibility of that world have yet to be developed; the linguistic, philosophical, and political-economic conditions that obtain operate continuously to take away "the vertical dimension. . . from female becoming."26 That is, the development of female subjectivity is not described as naturally entailing an orientation towards the heavens, and is not encouraged to adopt that orientation.

The potential builders of this not-yet-world that would include such a vertical dimension will need "an intuition of the infinite" that supports a "love of other" rather than, as has been more traditional, a hatred of other. ${ }^{27}$ This intuition, whether of God or of a subject appropriately open to a complex form of becoming, calls for a renewed symbol, a call that raises intense resistance. Her simultaneous proposal and disqualification of "sexual difference" as a "living symbol" demonstrates that sexual difference fails as a symbol in the first instance because it functions as literal language. ${ }^{28}$ To the extent it functions symbolically, it functions in ways already pre-scribed by

\footnotetext{
25. Irigaray, Ethics of Sexual Difference, 5, 214-217.

26. Ibid., 108-109.

27. Ibid., 112 .

28. Ibid., 113.
} 
the discourse that operates to block the imagination and construction of the fecund new world. That discursive situation informs other claims, including her identification of women's traditional "immediate" relationship with nature (as revered in romanticism) or with God (as in the examples of female mystics), and illuminates other suggestions in Ethics, such as the "mucous" of the interior of the body, or the potential "caress" of its exterior.

Irigaray's discussion builds on her early development of a reading of Diotima in the Symposium that perceives a complex dialectical movement between here, beyond, and the two poles of whatever dialectical encounter. The internally polarized "third term" or mediating path, which in the Symposium is occupied by love, changes the oppositional character of the more familiar Hegelian dialectic. It constitutes a dynamic relation between the poles of the dialectical engagement. On Irigaray's reading, this incipient dialectic comes to be superseded by a less complicated, more oppositional understanding that comes to privilege an incorporeal contemplation of beauty, separated from its character as "sensible transcendental," by the end of the Symposium. ${ }^{29}$

Nevertheless, if Plato's readers can trust Socrates' report - not a small if - they can discern and consider Diotima's dialectic, since it is on display throughout the entire discourse. The way of love described by Diotima permits the undoing and opening up of all seemingly binary oppositions. That way permits a continuous movement between "here" and "beyond," a reverse as well as a forward motion, and a dynamic presence that does not seem to presuppose a closed ontological substance. After all, this way is a "way," a form of

29. Ibid., 20-33. For a critique of Irigaray's reading of the Symposium, see Andrea Nye, "The Hidden Host: Irigaray and Diotima at Plato's Symposium," Hypatia 33:3 (Winter, 1989) 45-61. 
relation, not a "thing" to be grasped and possessed. In fact, this way of love is precisely the way of philosophy, the way to wisdom and to apprehension of what is good and beautiful. It is also a "neutral" and thus "utopic" way between two opposing poles. Whether it works as a neutral ground from which to produce a closed and static utopian vision, or an open and dynamic one, seems to depend on who does the mapping.

Irigaray calls particular attention to the exchange between Socrates and Diotima around the question of whether Eros is a "great God." The exchange provides an example of Diotima's method, and illustrates Socrates' will to tie things up in a closed, binary context of judgment. Moreover, the question of the identity of the God who underwrites the way of love remains relevant throughout Irigaray's Ethics, and she returns to the question more than once. She reminds her listeners and readers of Heidegger's insistence that "only a god can save us now" as she suggests that a "sensible transcendental" will come into being as a mediation "between" the two poles of an internallydifferentiated "we" whose relation would bring this dynamic bridge into being. 30 Later, as she begins to address the "Love of the Other" explicitly, she places the task of the love of the other into the religious frame of a divine appearance in the flesh:

Does parousia correspond to the expectation of a future not only as a utopia or a destiny but also as a here and now, the willed construction of a bridge in the present between the past and the future? . . Would crossing through the neuter - the space-time of remission of the polemic? - set up the return or reappearance of God or of the other? . . . Why should this theology or theologality of hope remain a utopia? Not an inscription in the flesh. An atopia. ${ }^{31}$

30. That is, in implicit opposition to Heidegger, the bridge does not construct the two sides of the mediated relation. Irigaray suggests, rather, that the sides, however many, in and by their relation bring about the bridge. Irigaray, Ethics of Sexual Difference, 128-129.

31. Ibid., 147. 
That is, it seems that the only dream of presence that has been permitted to western thought has been one that presupposes the absence of a place for its taking place, a presupposition implicit in the "ou" or emphatic "not" of u-topia. Why might this place not possibly take place in the here and now, in the place already occupied by the material of flesh and blood? Maybe the NO-place of utopia is just the so-far non-place of something that is possible but that humanity has so far been without: a-topia, without place, a deprivation or denial of place. ${ }^{32}$

In this passage she invokes once again Diotima's dialectical bridge, already established as a bridge named "eros," which mediates time (here and now, beyond) as well as dialectical polarities. Now the bridge is set between a present and a utopian beyond, and the approach to the utopian beyond is linked both to the image of religious transcendence and that of the transcendence of the other in the flesh. The problem with this possibility is that the conditions for its philosophical reception are not yet prepared, as she indicates in her readings of Merleau-Ponty and Levinas. The western anticipation of a divine parousia continues to be developed in a willful refusal of recognition to the bridge of the flesh. One consequence is that the understanding of God so developed is separated from the sense of bliss in touch, and "will always be thought of as a god who touches in suffering but not in joy or bliss." ${ }^{33}$ This suffering is the very suffering the utopia suggested in Ethics would challenge.

Throughout this text, Irigaray is drawing out the implications of a "way" that remains dynamically accessible both backwards and forwards,

32. In the sense that a-phasia is a loss of speech, in a context of the possibility of speech, or an-hydrous refers to something that makes do without water on a watery planet.

33. Ibid., 162. Irigaray's statement is made in the context of her reading of Merleau-Ponty. Elsewhere she challenges its generality. 
from "here" to "beyond," perhaps a "beyond" that moves in more than one temporal direction, and uses the device of a "God" or god, who is a counterpart of an other as subject, to designate the "beyond" of this way. Involved throughout, most clear in her discussion of Merleau-Ponty, is the "invisibility" or "blind spot" constituted by the maternal, incarnate matrix in its relationship to philosophy, and in particular the disappearance of the mother's daughters.

Her discussion of color in her extended response to Merleau-Ponty calls to mind Adorno's use of the metaphor of color, a color that emanates from non-being, which it is the task of philosophy to mediate. Adorno's metaphor is closer to Irigaray's understanding of the dynamics of color, which for her emanates from a source that has persistently been suppressed in the history of western philosophy, but, ineffably, remains available to in-corporation in philosophy, generally unconsciously and in the manner of exclusion, and that needs to be made conscious. This making conscious would constitute a way towards freedom and represent utopic practice.

In short, An Ethics of Sexual Difference develops a complex, immanent set of suggestions about utopia, utopic practice, and the relationship of philosophy to that practice. It promotes that practice, less as a foolhardy "utopia" than as a possible becoming with transformative potential, particularly in a dire technological context. It lays out Irigaray's specific understanding of dialectical relationship, which continues to appear in her later work, and indicates some of the significance she assigns to this utopic dialectic with respect to space-time. It introduces the significance she assigns to the notions of "way" and "philosophy." In particular, it indicates the origin of the "way of love" she describes Diotima as advocating, and Socrates limiting in a way that imposes premature closure, on which 
she will reflect at length in her text The way of Love. It elucidates her concept of the "sensible transcendental" that underlies her treatment of the "beyond" to be cultivated between sexually different subjects. It introduces her term "flesh," which differs micrologically from "the body," and'which functions as the subsistence of a network of non-fungible intersubjective relations with ethical implications. ${ }^{34}$ The relations Irigaray depicts as utopian she also depicts as pleasurable, although the precise nature of the pleasure associated with these relations is not examined. The concluding discussion of pleasure counterbalances remarks by Socrates about happiness, and its source, in the discussion of the Symposium. However, in I love to you, Irigaray reiterates the utopian impulse to happiness in a distinctly concrete treatment.

Happiness must be built by us here and now on earth, where we Iive, a happiness comprising a carnal, sensible and spiritual dimension in the love between women and men, woman and man, which cannot be subordinated to reproduction, to the acquisition or accumulation of property, to a hypothetical human or divine authority. The realization of happiness in us and between us is our primary cultural obligation. ${ }^{35}$

Love's Negative Dialectical Labor

In I Love to You, Irigaray goes on record against the utopian designation, insisting that she is ". . a political militant for the impossible, which is not to say a utopian. Rather, I want what is yet to be as the only possibility of a future."36 Rather than a "utopian" program and practice, a program oriented towards an unreachable ideal in relation to which its actual objectives always represent a fallingshort, Irigaray writes in favor of a political practice that aims at objectives now considered impossible as the only practical political

34. Irigaray, Ethics of Sexual Difference, 217.

35. Luce Irigaray, I love to you, translated by Alison Martin (New York: Routledge, 1996), 15.

36. Ibid., 10. 
program. The subtitle of the work, "Sketch for a Felicity in History," underscores her treatment of the "happiness" at which she aims as a material, historical objective. Treating I Love to You as a text that constructs a representation of utopia remains permissible as long as it is permissible to treat "happiness," and its determinate possibility, as a focus for utopian discourse.

With some confidence that it is, Irigaray's description of the shape of the felicity in history towards which her thought moves outlines what this argument would categorize as a utopia grounded in a specific form of communication or "communion" that would involve:

. . a new economy of existence or being which is neither that of mastery nor that of slavery but rather of exchange with no preconstituted object - vital exchange, cultural exchange, of words, gestures, etc., an exchange thus able to communicate at times, to commune . . . beyond any exchange of objects. What we would be dealing with, then, is the establishment of another era of civilization, or of culture, in which the exchange of objects, and most particularly of women, would no longer form the basis for the constitution of a cultural order. ${ }^{37}$

This description is explicitly and directly a commentary on LéviStrauss's analysis of culture as the exchange of women, and also constitutes a repudiation of the culture built around the exchange of commodities criticized by Marx in his long philosophical and political critique of Hegel and of the philosophers' reserved efforts to understand rather than change the world. The main text, set between a prologue and epilogue that combine personal and conceptual resources for its reading, sets out from a comment on Marx's avoidance of the original problem of man's exploitation of woman and the sexed division of labor. This avoidance, the origin of which she in turn locates in Hegel's philosophy, and its treatment of love as labor, she identifies as her focus. I Love to You then becomes a terse, condensed critique of

37. Ibid., 45. 
Hegel's dialectical account of the development of civil society and its fruit in spiritual self-awareness, and the development of an alternative "double" dialectical program that accomplishes a correspondingly more adequate, and more consistently negative, approach to the cultivation of the passage from nature to culture.

I Love to You here shares a limited structural similarity with Adorno's far longer Negative Dialectics. Irigaray's text echoes Adorno's initial invocation of Marx, and his inaugural announcement of the objective of the work as a return to philosophical investigation in the wake of an inadequate working-out of the historical materialist demand. Irigaray's extended engagement with Hegel and the development of a dialectical project that will hinge on something she terms "the labor of the negative" emerges as another similarity. This labor of the negative elaborates the "way of love" she discerned in Diotima's discourse from the Symposium, the dialectical exchange that proceeds by way of an ongoing relation-in-distinction of dialectically engaged positions. Here, the "negative" stems from the determinate negation of a presumptive human totality constructed around man's subjectivity that is provided by woman's subjectivity, and vice versa.

For Irigaray, this always already available negative resides in sexual difference. The implications of sexual difference for Hegel's dialectic entail an opening up of Hegelian totalities that serve as the identities on which Hegel's dialectical moves pivot. Hegel's version of natural immediacy is an illusion; the assumption of a sexed subject implies an always partial and incomplete, rather than full identification with nature. The negation of that false identity is "not a real negative, even if it is mortification" and the thinking that proceeds from it is a dreamy pseudo-thinking that "has had to unfold over centuries in a sort of somnambulism" without even becoming real 
thinking yet. On the other hand, the self-limiting potential of an internally differentiated nature would permit man [sic] "to postulate the infinite without an anti-natural labor of the negative," not having to deny an already-constituted "whole" to make possible some form of becoming. ${ }^{38}$

At every point of her argument, she deploys the self-limiting, participative nature of sexual difference to deconstruct Hegelian totalities, and to challenge the violence and domination implicit in Hegelian negations. The mutually limiting poles of sexual difference are not opposites; they are differences. They do not synthesize in a mutual negation that might be called "neuter," like the allegedly neuter citizen of the sovereign state, which turns out to be Man, the Same, writ large. Rather, the recognition that founds a collective that can be designated "we" in a precise way, that incorporates a relation of communication between different subjects, "is constituted by subjects irreducible one to the other, each one to the others, and thus capable of communicating out of freedom and necessity. . . Speech between replaces instinctual attraction or the attraction of similitude. ${ }^{39}$

I Love to You makes this communicative "we," at least symbolic of the place from which the felicity possible in history can be constructed, if not concretely constitutive of it. Significantly, "we" has the linguistic form of a universal, but in enunciation always refers to a particular constellation of subjects in being. ${ }^{40}$ The structure of the we-relation incorporates the "double dialectic" of a

38. Ibid., 40-41.

39. Ibid., 104 .

40. This form, that of the "shifter," is common to all the personal pronouns. For a relevant discussion of how personal pronouns mediate universal concepts and concrete subjects of enunciation, see Giorgio Agamben, Language and Death, trans. Karen E. Pinkus with Michael Hardt (Minneapolis: University of Minnesota Press, 1991) 19-26. 
relation of sexual difference across and through a bi-directional trajectory of cultural mediation. For Irigaray, the space figured by the relationship of indirection re-forms and makes appropriable a recognition between different subjectivities that was always already available, but not actualized. The "we" becomes a place where sexed differences in the use of language, which have been a focus of Irigaray's research, become the media of a different form of communication, an exchange of words that departs from the pattern of an exchange of objects, and begins to take on the contours of an exchange of subjectivities. Drawing on both Hindu and Christian religious symbolism, she presents a compressed description of tantric practice, and a "non-patriarchal interpretation of the Annunciation," as symbols for such exchanges and their capacity for the cultivation of transcendence within history and culture. ${ }^{41}$

"This we still has no place." 42 The construction of a place for this we of a felicitous exchange that does not involve the exchange of objects entails a political as well as a linguistic and philosophical program. Linguistically, the task may be sustained by developing a relationship of "indirection," space, between the terms of the dialectic: "I love to you," a syntax of indirect objectivation that supports inter-subjectivity, rather than "I love you," a syntax of an objectification that has historically spelled the denial of the other's subjectivity. ${ }^{43}$ Here the term "objectivation" struggles to communicate discourse in which an object position does not automatically coincide with a loss of subjectivity, unlike the "objectification" with which everyone is all too familiar.

41. Ibid., 138-141.

42. Ibid., 48 .

43. Irigaray, Ibid., 109-113. 
Politically, Irigaray's concrete recommendations strike many of her readers as distinctly dystopian, as she advocates granting "women and men rights corresponding to the reality of their respective needs." 44 This program produces dismay even among those who are favorably disposed to reading Irigaray's obsessive emphasis on sexual difference as capable of reconciliation with the concrete political and social needs of subjects whose articulation of difference belies the adequacy of the man-woman relation. ${ }^{45}$ It illustrates the potential slippage between her uses of sexual difference. Sexual difference in Irigaray's work can be a symbol that figures a site for human intersubjectivity and transcendence, a site with the potential to challenge established exclusions and foreclosures. Sexual difference may also be used as an available framework for a practical political program, which may or may not challenge such exclusions and foreclosures. The question is whether a utopia imagined under the influence of Irigaray's discourse makes use of, or demands, a particular kind of dwelling in sexual difference, and whether this habitation of sexual difference permits, or actively demands, participation in prescribed forms of heterosexual intersubjective exchange. That question is not resolved, but raised yet again, in Irigaray's later texts, on the Way to Love and Sharing the World.

\section{Sharing an Intersubjective World by Way of Love}

In the remarks that conclude the text of I love to you, Irigaray develops an image of history as something that could be articulated "between two," in a process that preserves a vital, creative space of non-identical relation. This space would be secured by the mutual

44. Ibid., 132

45. See in particular Cheah, Grosz, Butler, and Cornell, ibid.; Penelope Deutscher, Mary Beth Mader and Alison Stone, Critical Exchange, differences: a journal of feminist cultural studies 19:3 (Fall, 2008) 126-157. 
recognition of an irreducible difference between the participating subjectivities. The history built in this way would be a felicitous one, which in other contexts might be labeled "utopian":

We can construct a History on the basis of an interiority without power. We need to be two for this task, a man and a woman. Two indefinitely, weaving relations between nature and culture, the universe and society. ${ }^{46}$

What follows this affirmation is a lyric, or hypnotic, paragraph on "Air, that which brings us together and separates us" and "which gives us forms from within and from without." 47 These could ideally be aesthetic forms that are simultaneously forms of address and autopoietic works of art.

The notion that an intersubjective context in which transformative intersubjective relations modeled on amorous exchange require "a man and a woman" cannot possibly strike all of Irigaray's readers as "utopian." That problem calls for further consideration, though not yet here. Here her reference to "an interiority without power" requires attention. In describing the site of a cultivation of this envisioned interiority without power, Irigaray constructs what can be read as a utopian condition. In her account, this cultivation takes place in the operation of a dynamic, dialectical and discursive intersubjective relation. This construction process receives its most explicit development in the recent texts The Way of Love (La Voie d'amour, 2002) and Sharing the World (2008). These texts constitute repetitions or iterations, with variations and extensions, of Irigaray's appreciative, appropriative, and passionately critical response to Heidegger, especially the Heidegger of on the way to Language. ${ }^{48}$ They elaborate a

46. Irigaray, I love to you, 148 .

47. Ibid., 149 .

48. Martin Heidegger, On the Way to Language, trans. Peter D. Hertz (New York: Harper and Row, Publishers, 1971). This text includes essays initially 
common and clearly utopian scene which takes shape as an explicit and critical alternative to its dystopian counterpart.

The texts' formal structure is remarkably similar. Both are arranged dynamically along stages of a journey from a subject position through an encounter with a differing subjectivity and towards reconstitution of an exterior and interior world affected by that encounter. Differences in sequence and timing highlight differences in emphasis between the two texts, as well as a progression of thematic treatment. The treatment of sexual difference, in particular, undergoes some modulation between the earlier and later texts. So, in The way of Love, the movement from self to other is compressed, and readers' last image of the differentiated subjects is of their suspension in a space between two, poised to reconstitute the world; in Sharing the World, the journey expands, with more text-time devoted to its initial stages, and to the consequences of the return trip.

Both texts elaborate the dynamic, potentially utopic, scenography that could underwrite the cultivation of an interiority without power. This scene begins with a differentiated - in the first place, sexually or sexuately differentiated - human subjectivity; moves into encounter with and relation to a sensibly transcendent other; then returns to self and the possible creation or co-creation of a world that sustains its differentiated separateness in relation. Irigaray calls attention to the utopian possibilities and the dystopian threats related to this unfolding scene. The author's role becomes something like that of a guide on a tour of the imaginary. Both texts locate the clearing of this place of utopian possibility in a transformed relation to language. The transformation is made possible by a recognition of irreducible

collected in Heidegger's Unterwegs zur Sprache. See in particular The Way of Love, note, xxi-xxii. 
subjective difference, a difference that escapes such traditional forms for understanding as binary opposition or collapse into undifferentiated neutrality. ${ }^{49}$

What can be discerned through these texts is an adamant opposition to the closed systemic understanding of language that Heideggerian philosophy and Lacanian psychology collaborate in designing. This "airless" world crammed with language that leaves no space for difference or differing with respect to the matter of language is a function of the philosopher's presuppositions. ${ }^{50}$ As Irigaray notes "[t]o claim that nothing would be there where the word is lacking means to deny the existence of the other and of that which remains unspeakable where two worlds join together."51 when the philosophy that understands the world people encounter as a function of the language people use to encounter it joins forces with a psychology that forecloses any possible articulation of the interiority and specific desire of woman, the two engineer a house of language that is less a prison-house than an abattoir for woman-as-subject. ${ }^{52}$ Challenging this particular totalitarian possibility is at the heart of the way not yet taken to language being scouted by Irigaray in these texts.

The alternative way emanates from the possibility of a language which "favors the act of speech in the present, and not a language already existing and codified." ${ }^{53}$ Such language is explicitly not language as the lifeless corpus of a simply pre-existing system of fixed meanings. It is instead language as a living - therefore

49. For instance, understandings that reduce woman to "other-of-the-same," or to an accident of an essentially single humanity.

50. For instance, the view adopted from Aristotle that language points to a universal human relationship with matter or matters. See Martin Heidegger, "The Way to Language," in Basic Writings, 401.

51. Irigaray, Sharing the World, 5. The "claim" is Heidegger's in on the Way to Language.

52. Abattoir, standard French for slaughterhouse, is also slang for a house of prostitution.

53. Way of Love., ix. 
transformable as well as transformative - matter. A way of language like this can be explored beginning with a situation in which "[e]ach subjectivity. . has before it a source of words foreign to that in which it dwells."54 This confrontation of a subjectivity, in a context of sexual difference, is probably most easily read as an evocation of amorous exchange. At times, however, it also evokes the confrontation and communicative task of mother and child, which in Irigaray's presentation is ineluctably either a mother-daughter or mother-son relation, in infancy. 55 This "foreign source" would properly prompt a recognition of a possibility of a different relation to language and meaning than that perhaps presupposed by the subject. Cultivating the possibility inherent in this situation requires "entering into a new epoch or language . . In which saying is no longer constituted in an ecstatic - ek-static - manner with respect to the real and its becoming." 56

Instead, in this new relation to language, in which "no word is yet available, no 'object' constituted" and yet in which "there is not nothing," the subject may be "on the way to regions of the encounter with oneself, and with the other" that beckon beyond "the obstruction produced by speech itself and its silences not yet attentive to such dimensions."57 Here, the utopian "not yet" of the new epoch or era of language is a double one: the new language is "not yet" language, it

54. Sharing the World, 6 .

55. For instance, Irigaray explicitly calls out the sexually-differentiated structure of the mother-child situation at the outset of sharing the World. "To cultivate the relations with the one who brought you into the world does not involve the same elements for those who are the same as her or different from her - that is, for a female or a male subject." Lacan's solution of interposing the "paternal law" between the ill-theorized early infantile relations "evades the problem by repressing it." See Sharing the World, 3. Giorgio Agamben reminds readers that the meaning of "infancy" is literally to be without speech - though precisely not without the capacity to experience language. Giorgio Agamben, Infancy and History: An Essay on the Destruction of Experience, trans. Liz Heron (London: Verso, 2007) 54.

56. Ibid., 16.

57. Way of Love, 44 . 
does not exist as a pre-scriptive system of names and corresponding objects, and the old language is "not yet" undone as language, though it could yet be. An attentiveness to its silences and spaces amounts to an attentiveness to already-existing possibilities latent in what is unsaid if not always unable to be said in its particular vocabulary, grammar and syntax.

Heidegger's treatment of language as a "house" or "dwelling" for being fails as a treatment of the language Irigaray imagines here. This language, which might support the co-construction of a world that does not yet exist - a more nearly utopian world - offers very little shelter. The subject "finds himself in every instant unsheltered by the crossroads where the other waits for him, and by a springing forth of meaning unknown to him." ${ }^{58}$ The linguistic demands of using language to "succeed in transforming what happens, from within or without, into saying" are rigorous. ${ }^{59}$ However, failing at this task destroys the possibility of the intersubjective relation. Succeeding requires relinquishing language as a fixed abode, and embracing the continuous re-invention of language, and the preservation of space, silence, "air," through which an intersubjective "proximity" can be cultivated that does not regress to a denial of difference. ${ }^{60}$ Irigaray's imagination likewise challenges Benjamin's depiction and by extension, Adorno's - of a language of pure names as utopically paradisiacal. In Benjamin's treatment, a language of names rather than signs represents a language not yet alienated from, because still one with, the substance it means. This dream of Adamic language as the language of the utopia that achieves "substance in cognition," Irigaray renders as a nightmare. For Irigaray, "[d]enomination results from a

58. Way of Love, 58 .

59. Ibid., 64 .

60. Ibid., 67 . 
mastery, even if it lets the thing or the other be thanks to the name given to them."61 Denominative language still brings the other into "one's own" world, bypassing the effort to build a shared world, that constitutes a place of meeting between different worlds. The evidently utopian possibility for Irigaray is not a reversion to a language of names in perfect communion with their concepts that would correspond to the "reconciliation" envisioned by Adorno. Instead, Irigaray advances the dream of a new, not-yet-invented language that lies somewhere between "a concerted denomination" - a language of names - and "wordcries manifesting a simple affect," - a purely animal communication of feeling - that would constitute "indirect ways of advancing" into mutually intelligible relationship. ${ }^{62}$ This still imaginary language of inter-subjective exchange preserves, according to Irigaray, the intrinsic mobility or temporality of things. ${ }^{63}$

Silence and listening are indispensable to the creation of this new linguistic mediation of intersubjectivity. Silence constitutes a gesture of welcome, a willingness to make a place for a meaning that cannot be shared, because it belongs to someone else. This welcoming silence resonates with the utopian "not yet," in that it "requires an availability for that which has not yet occurred."64 In elaborating this silent welcoming, Irigaray contrasts the gesture of welcome that is silence with a more traditional form of hospitality, the room reserved for some one who might yet arrive and need shelter. This form of welcome, presumably better than no welcome at all, nevertheless fails to respond to the particularity of the other whose "call" provokes the subjective response. It is too generic. Moreover, as a pre-arranged

61. Ibid., 48 .

62. Ibid., 58 .

63. Ibid., 62 .

64. Sharing the World., 18. 
empty space, it leaves the welcomer's world unaffected. The potentially transformative call of the particular other calls for a kind of silence that involves silencing - making silent - already existing meanings. A "guest room" made available in a generic way does not answer the requirement; the response to the call of the particular other with whom new language will need to be made requires clearing out an alreadyfilled space. That is, it requires discarding or setting aside already existing meanings, concepts, understandings. ${ }^{65}$

The need for silence does not end with welcome. It continues throughout encounter, facilitating a dynamic process of withdrawal, approach, renewed encounter, recognition or memory and change on the part of the participants and within their relation, and re-constitution of the participating subjectivities. The key to this dynamic is "the silence of a not-yet-come-to-pass" which underwrites a re-imagination of the classically utopian picture of the reconciliation of nature and culture. ${ }^{66}$

Irigaray retains the analytic polarity of nature and culture, while seeking to re-map its relationship to sexually differentiated subjectivities. The differing subjectivities of man and woman each have their specific relationships with nature, as well as with culture. An archetypal example of this sexually differentiated relationship is the relationship to the maternal body, which differs for woman and for man, as between a relationship to "being like me" and "being different from me." The silence of the not-yet-come-to-pass holds open and un-prescripted "the place always to be re-articulated between nature and culture, between letting be and constructing" and "necessitates

65. Ibid., 19-24.

66. Way of Love, 126. 
implementing a temporality until now unknown." 67 This novel temporality mediates a dialectical becoming of an inter-subjective relation between two differently dialectical intra-subjectively becoming subjects.

Irigaray's view of welcome and encounter comes with ontological implications, already elaborated in The Way of Love. The new era of linguistic and relational spaciousness constructs a place for fertile relationships across difference. The "groundless ground" woven by this relation challenges the sufficiency of the ground composed simply of all of being, apart from the differentiated relations of beings. Irigaray's critique of the more familiar formulation notes first that it willfully denies the experientially primordial intersubjective relation with the mother. She speculates that this denial masks an even more fundamental denial, the denial of other subjective worlds that challenge the wholeness of the subject's own. ${ }^{68}$ In every case, what makes way and space for a potentially utopian relation is the acknowledgement of particularity - not being "all" - that is a possible, and ethical, response to a different subjectivity.

In fact, Irigaray locates the danger of essentialism, so often attributed to her recurrent stress on sexual difference, in the avoidance of that difference and its possible implications.

I discovered that, in fact, we cannot be - "être" (Being) without falling back into a simple substance, outside of a being in relation with an other of sexual difference. In such a relation, which undoes any fixed essence, or substance, we can have access to our own human Being. I could say: to an existence which would not be a simple passivity, notably with regard to the construction of space, time, and the relation with the other(s). Such a human 'Being' is always in becoming even if it exists, or ought to exist, in every instant. ${ }^{69}$

As always for Irigaray, the initial condition of possibility for a more desirable alternative - i.e., the initial condition of utopian

67. Ibid.

68. Way of Love, 72-77.

69. Ibid., xiii. 
possibility - is irreducible difference, "beginning with the other of sexuate difference."70 The irreducibly different subject sets a bound to "my" world, provides an external source of transcendence, and demands a corresponding interior transcendence from me. As she depicts the potential rewards of cultivating the intersubjective relation of irreducible difference, she reaches for lyric prose. This relation engenders a soul that is more than empty space, that comes into being in and through relation with an original matrix. It permits the celebration of "the feast of love.. . gathering together the mortal and the divine, the earthly and the celestial in an encounter where giving and receiving are exchanged in the elation of the present."71 It "is also a way to escape the nihilism threatening our tradition as well as its critique" by "being faithful to a different truth from the one, dependent on a supra-sensible absolute, that has both exiled us from ourselves and separated us from one another."72 Irigaray uses archetypal imaginary relations, mother-child, lover-beloved, pious contemplativeGod to locate the utopian opening in its usual place, but hanging by a different thread. The mother-child relationship no longer represents an idyll of reconciliation with nature, but the original intersubjective studio; the creative impetus in that relationship proceeds from irreducible difference. The lover-beloved relationship does not begin and end in ecstatic communion, but requires the safeguarding of baroque thresholds and separate rooms or worlds. The pious contemplative may need to be taught to sense the transcendent in the earthen vessels that his neighbors, maybe even "the women at prayer," offer in their

70. Sharing the World, 135 .

71. Ibid., 131.

72. Sharing the world, 135. 
irreducible difference from him, less superficial and identical than he has yet divined. ${ }^{73}$

The utopian moment this discourse summons does not, however, arise exclusively in the elaboration of a transformed intersubjectivity. It has at least as much to do with the transformation of the intrasubjective construction process, the engendering of new possibilities for interiority. Hence arises the importance of the "return to self" and the processes of "self-affection" along this way. ${ }^{74}$ Hence, also, arises the importance of an other who facilitates such a return, who challenges and cultivates the different, rather than an other who prohibits the return, or who simply reflects the subject statically. An indispensable interiority is constructed discursively and dialectically, from the groundless ground of the intersubjective relationship, albeit not without the participation of something already present, even if not-yet-called. The description of the intra-subjective consequences of the inter-subjective encounter elicits some of Irigaray's most intensely utopian prose. She describes here, literally, a process of inspiration: it depends on "air" or "breath" and activates something beyond sense already present in the bounded subject, but not yet active. In the aftermath of the encounter, this interior, or perhaps interiorized, different other stimulates a response of and by a dimension of the self which was "not yet," a latent dimension of the subject's own explicitly real potentiality. ${ }^{75}$

The opportunity for an inspiration of this kind requires preparation, in particular the preparation of a "return," a way back to the self from the encounter with difference. Irigaray's emphasis on the

73. Cf. Stefan George, "Entrückung."

74. See in particular Irigaray's discussion of the moyen-passif as a linguistic form indicating intra-subjective, auto-affective process. Way of Love, xiv-xv.

75. Sharing the World, 48-50. 
threshold, something that requires building, preparation, that opens both ways, outward toward another, and inward toward the self, something that might connect to a path towards the other, that signals an opening to the other, but that also represents indispensable boundary conditions, preservation of the possibility of an interior place and a time for withdrawal from encounter, stems from the requirements of subjectivity itself. Far from constituting an eternally given, a priori, essence, these irreducibly different subjectivities remain subject to becoming from their inception. Building the threshold precedes the development of full interiority, and makes it possible. For there to be a "between-two," with its possibilities, there also has to be a one and another, with theirs. Irigaray offers a model of relationship between two differing subjects who are themselves made, both self-made and other-made, differently, in the encounter. This relationship could, or would, in her view, constitute a "micro-culture" that "can become the leaven for a universal culture that keeps alive the energy of each one as well as that of the relation between the one and the other."76 The "leaven" of a new quality of interpersonal relationship generates its own ethical boundaries, organically, from the dual dialectical movement of the related parties" dual "return to oneself" and "opening to the other." In a dialectic not frozen in language or in pre-determined and immutable cultural forms, the restraints imposed by each one on "oneself" out of respect for the integrity of the other constitute "moving boundaries" for a "restrained flowering" of each. 77

"Between the two is thus preserved a becoming that is still to be elaborated - for the one, for the other and for their relations. It is

76. Sharing the world, 57 .

77. Ibid. 
a sort of always virginal space safeguarded through the attention that each one accords to the other in their transcendent alterity."78 That is, the space "between-two" remains a perpetually open, as yet untouched, as yet unmet, space of and for possibility. Her subjects-becoming-inrelation require proximity. The kind of proximity they require would be unthinkable in a closed or "total" relational or metaphysical context. Proximity in a closed context reduces every meeting subsequent to the first to a re-meeting. A second encounter would always take place on the same terrain, a terrain that is now being gone "over," or "over again." The temporal dimension becomes particularly important, then, as the incorporation of this temporal dimension, which remains open to a becoming that is not closed off but remains open-ended, permits encounters always to be on new "ground," or in new "space-time," Diotima's double dialectic, which can only in one sense be designated as a re-encounter, but must necessarily be at the same time a new or species of first encounter, the next encounter, and the next encounter being always, for Irigaray, in this analysis, a preservation of "always virginal space."

The complex arrangement of thresholds, double dialectical interand intra-subjective movements, newly articulated temporalities, airy shared worlds and spaces of withdrawal into self all issue, all along the way, in that most utopian of affects, happiness. Happiness in this context will explicitly be a transformation of "our essential disquiet and unhappiness" in the context of "the uncultivated, inhuman, unhappy, and 'fallen' . . character of our intersubjective relations."79 "The desire for happiness in this context is dismissed "by most adults as an adolescent dream," perhaps because the cultivation of the imagination,

78. Ibid., 61 .

79. Sharing the World, 75 . 
and in particular the "transcendental" imagination, has not been adequately undertaken. ${ }^{80}$ Irigaray's characterization of philosophy as the way of love is an explicit response to a specific constellation of suffering, perhaps worth quoting at length:

Whoever knows the gathering together into the most intimate only through suffering, does not know the illuminating grace of love. This also, thanks to another light than that cultivated by our metaphysics, opens a place of resource and of meditative gathering. It implies, it is true, the ability to let be as much as to make. And the acceptance of a sharing between shadow and light. ${ }^{81}$

The construction of something that can be read as utopian in these texts rarely touches on the question of suffering. But the transformative processes proposed, in their deeply poietic and autopoietic effect, have the "transubstantiation" of the matter of suffering as their explicit aim. ${ }^{82}$

In that connection, Irigaray turns as does Adorno to the image of transcendental light. This "other light" that enters and enlightens, "notably through desire," does not simply emanate from the other whom a subject might identify as the object of desire. Seeking to merge, or merging, with that object in a quest for complete illumination would be futile. ${ }^{83}$ The light seems to emanate less from a univocally-defined subjective or objective location as from the relation, and the attraction that arises from it. The embodiment of attraction in action causes the encounter to "brighten." 84 The Way of Love concludes with a meditation on light that radiates imperceptibly within the encounter of different subjects, taking on the form of affects like peace or joy, or being formed into touch, which then has the ability to impress both

80. Ibid., 55 .

81. Way of Love, 173 .

82. Ibid.

83. Sharing the world, 129-130.

84. Ibid., 52 . 
self and other. ${ }^{85}$ Philosophy becomes less the prism in which the color of this light is caught, as the way along which its force is felt. Features of Irigaray's Utopian Scene

Several features of Irigaray's evocative construction of a utopian scene link her work with that of Adorno and Agamben. First, the possibility of the utopian lies in a shift in basic theory, to be explored and promoted through her writings. What is utopian in Irigaray's work is ultimately a conceptual matter. Second, this conceptual matter demands a specific textual practice that makes her work extraordinarily difficult to receive, even for those women or men or other readers who might otherwise be most inclined to value it, if not especially for those. Third, her utopian construction involves a rethinking of the subject-object relationship. Specifically, Irigaray's utopian emanates from her re-specification of the subject-object relationship as a subject-subject relationship. Fourth, this alternative intersubjective paradigm calls forth a special treatment of language, which forms another element of Irigaray's utopian scene. Finally, this utopian scene requires an imaginative modification of the customary organization of time and space.

\section{Theory as Praxis}

Like Adorno, Irigaray presents her work of re-conceptualization of sexual difference, and its connections with basic philosophical questions, as directly practical. Her work constitutes philosophy undertaken as praxis, as practical activity. The active and interventionist quality of her work responds to what she has identified as the conceptual foundation of women's political disadvantage. The fundamental conceptual and symbolic contours of western thought and language, which she analyzes in detail in Speculum, produce the

85. Way of Love, 174 . 
exclusion of woman from western thought and language. The "aporia of discourse as to the female sex" imposes the requirement of passing "through the master discourse: the one that prescribes, in the last analysis, the organization of language," which is philosophy, on the way to a possible solution. ${ }^{86}$ The aim of Speculum, in Irigaray's words, "is to construct an objectivity that facilitates a dialectic proper to the female subject," which is "both a philosophical and a political task." 87

The central philosophical and practical problem for Irigaray, beginning with Speculum, has been the exclusion of the very idea of the possibility of the objectivity of woman-as-subject by and from this dominant discourse, and all of the cultural products derived from it. Practical political approaches that address the consequences of this exclusion for women - violence against women, for instance, or inequity in the workplace - run up against this exclusion from language and intelligibility, and are forced to re-enact the possible subject positions that continue to exclude "woman" from subjectivity. The central problem of the exclusion of woman's subjectivity can only be solved conceptually. The quest for a solution must proceed by means of a demonstration rather than a direct statement of the problem. It entails efforts to invent new symbols, ones that can appear in the existing symbolic, whose content is sufficiently unspecified, ambiguous, and non-phallic to support the development of alternative significations.

Sexual difference constitutes a utopic horizon. But approaching that horizon, making it "work," is a matter of learning a new way of

86. Luce Irigaray, This Sex, 149.

87. Irigaray, I Love to You, 62 . 
thinking. "A revolution in thought and ethics is needed if the work of sexual difference is to take place." 88

One index of the difficulties associated with this fundamental reconceptualization is the storm of controversy that surrounded the publication of Speculum, and the debates around Irigaray's "essentialism." 89 Her project has met with a troubled reception precisely among readers who might otherwise be favorably inclined to accept the premise that the dominant phallogocentric or "homm(o) sexual" discourse of western philosophy since Plato systematically and systemically practices a compulsory exclusion of woman-as-subject, and exports that exclusion to such influential auxiliary discourses as science and psychoanalysis. The trouble stems from the perception that her language of "woman" reinscribes a pre-discursive, essential and prescriptive nature in the female body, read in a traditional and uncritically morphological way. That is, when Irigaray says something like "The wedding between man and woman realizes the reign of spirit. Without it, there is no spirit," she sounds like she might be able to make common cause with the crusaders against gay marriage. ${ }^{90}$ This seeming reinscription sounds suspiciously like an opportunity to reinforce the ideological assignment of a long list of "feminine" predicates to that essentially feminine nature. Irigaray's adamant insistence in Speculum that the construction of femininity to date has proceeded under the blueprint of an exclusively masculine subjectivity that has usurped the status of "human subjectivity" remains easy to forget in the face of this language. Irigaray's language of the relationship of "woman and man, man and woman" sounds suspiciously like

88. Irigaray, Ethics of Sexual Difference, 6 .

89. For a thorough review of this literature, see whitford, Philosophy in the Feminine; Chanter, Ethics of Eros.

90. Irigaray, I Love to You, 147. 
an acceptance of compulsory heterosexuality or at least heteronormativity. How queer sexualities and desire are supposed to articulate with Irigaray's project and language is not immediately obvious; to the extent that Irigaray locates hope for change in the irreducible difference between woman and man, she seems to deny the liberating potential of queer relationships. As a consequence, Irigaray's efforts to redesign an "objectivity" that facilitates woman's specific subjectivity seem to misfire at their most critical point of potential reception.

\section{Mimesis, Poiesis, Hypnosis}

The alleged confusion over Irigaray's actual purposes and meanings is exacerbated by the specific textual practices her project and method of rereading and reconceptualizing demand in the context of complete exclusion of woman-as-subject. Irigaray's texts are notoriously difficult to read. Their difficulties differ from those presented by Adorno on one hand and Agamben on the other, although they arise for similar reasons. In effect, Irigaray's texts are always already written in a foreign language, a language that has not yet been invented. Their purpose, which is integral to her central project, is to compose objective conditions for the development of a woman's subjectivity that has not yet been cultivated. Their task is to make use of existing language, but to use it as from a different subjective point of origin, to create a different objective horizon of interpretation. The devices she has adopted to accomplish this nearly impossible task are constitutive of the actual construction of the utopian in and more importantly by her work. These devices include her much-discussed mimesis, efforts in the direction of a "new poetics," and what could be called the hypnotic element of this new poetics. 
Irigaray's mimetic practice has generated comment in the literature. ${ }^{91}$ As Irigaray herself says, "The tool is not a feminine attribute. But woman may re-utilize its marks on her, in her."92 So, her texts mime the language and subject-position of the hysterical analysand in relation to psychoanalysis, or the language of the "philosopher's wife" or lover in relation to philosophy. Transformative discourse takes these "marks" and reverse engineers the blueprints according to which they were made, along with the models of reality that made them so seemingly well-designed, and simultaneously so damaging to actual women. Irigaray presents this particular form of mimesis as the only textual strategy available under the circumstances of the dominant discourse for someone with her project. ${ }^{93}$

Irigaray has called for "a new poetics" as well, which goes beyond the mimetic. 94 "Poetic language" may permit the cultivation of the specific "energy" proper to the coming into relation of sexually different subjects. 95 This "cultivation" is particularly desirable in Irigaray's presentation, since it would amount to the creation of an inclusively ethical human culture. The new poetic language Irigaray recommends, however, cannot simply reproduce the existing forms, associated with the phallogocentric symbolic order. In that order, metaphors, especially metaphors of the feminine, especially as analyzed according to a Lacanian account, inevitably work as displacements of the always already excluded, unrepresentable, and unintelligible "feminine subjectivity." Simply producing new images does not amount to the new poetics Irigaray speaks of here, even though new images may be

91. Whitford, Philosophy in the Feminine, 70-74; Grosz, Lacan: A Feminist Introduction.

92. Irigaray, This Sex, 150 .

93. Ibid., 136-137, 150-151.

94. Irigaray, Ethics of Sexual Difference, 5.

95. Irigaray, Way of Love, 136. 
necessary as "placeholders."96 Instead, this new poetics involves a special role of silence that dismantles or disqualifies older poetic forms. ${ }^{97}$ It involves fewer nouns and more verbs, more attuned to the linguistic function of "modulation," whether of affect, mood, or tense. It is less economical, no longer involving an exchange of objects, but more revealing, an exchange of different selves. ${ }^{98}$ This new poetics then comes to be a genuine poiesis, creation from nothing, and a double auto-poiesis, a collaborative creation from a nothingness "which is not nothing" into and over the space of non-identity that lies between the two different subjectivities, the weaving of a "groundless ground." 99 What this poetics works with is matter, and it highlights the materiality of language, pre-eminently poetic language: gestures, voices, touch. The creation it effects includes civil engineering or architecture as well as textile arts; it constructs "bridges," "paths," "approaches" as it effects the mediation of interiorities that remain inviolately in relation. ${ }^{100}$

Irigaray's descriptions of this language that has not yet come into being are indeed lyrical, but they are, for all that, descriptive. They indicate the character of the desirable new poetics she envisions and encourages. Whether they enact it is less obvious, since they remain constrained by existing textual and symbolic forms. On the other hand, Irigaray's constructions of utopian scenes, her description of the new poetics enacted within those utopian scenes, are certainly aimed at cultivating in her readers the desire to participate in such scenes. Some readers describe Irigaray's texts as "poetic," but "hypnotic" might be a more precise designation.

96. Whitford, Philosophy in the Feminine, 71.

97. Irigaray, Way of Love, 44.

98. Ibid., 58-62.

99. Ibid., 174, 72 .

100. Irigaray, Sharing the World, 46-61, 128-130. 
The purpose of the hypnotic is to relay suggestions from the desiring conscious to the unconscious. Hypnotic suggestion arranges available symbols and elements of an imaginary constellation in a way that bypasses the censorship mechanisms of the conscious, with its vigilant super-ego, and makes new scripts available to the unconscious with which to organize its wish-fulfilling aims. Hypnosis might be indicated in a therapeutic context in which, as Irigaray notes, the subject in question suffers from an obsessive-compulsive projection which is impervious to rational dissuasion ". . because this projection of a world comes before any representation, judgement [sic], indeed any conscious feeling, it cannot be questioned in a rational way."101 A text that would have the potential to intervene in that subject's tautological system would need to find a way to operate simultaneously within and beyond that system.

Irigaray's descriptions in The Way of Love of the oneiric bliss of a yet-to-be-created intersubjectivity, achieved by means of a language that does not encode pre-scribed meanings, qualifies as such a hypnotic device. That description barely operates on a conscious level. The language she describes here fails as "language," within the present linguistic system; it is non-language, signs without system or agreedupon signification. It addresses itself instead to the unconscious reception of uncoupled connotations of "language:" communication and communion, expression and impression, contact, wondering and understanding. It seeks to stimulate an imagination of, and the creative desire for, something for which the word language no longer quite fits.

A final element of Irigaray"s "new poetics," or hypnotics, is the multi-vocal status of her texts. Irigaray's texts are self-consciously

101. Irigaray, Sharing the World, xii. 
multi-vocal, in Bakhtin's terminology, heteroglossic. For Bakhtin, poetic language strips away the heteroglossia present in actual life and presents it in reconfigured aspects, creatively bringing about new syntheses of the existing heteroglossia, under a unitary poetic umbrella. That analysis, however, remains within the system of exclusively masculine subjectivity that is the object of Irigaray's critique and textual practice. ${ }^{102}$ For Irigaray, the "poetic" function is to create the objective horizon for the development of feminine subjectivity as subjectivity. Her "new poetics" seeks to insert and make audible the heteroglossic feminine.

These elements of Irigaray's texts work towards representing, not the utopian itself, but the conditions of possibility for the utopian. They concern themselves with describing the operation of these conditions as desirable in themselves, in contrast to the undesirably singular, exclusive context of a single, always masculine, subjectivity that prevails at present. For Irigaray, as for Adorno, an element of her discursive construction of the utopian possibility is a respecification of the relationship of the subject and object of knowledge.

\section{Woman-as-Subject as a Condition for Utopia}

"Irigaray is a kind of cultural prophet," says Margaret Whitford. As such, she diagnoses the exposure of western society to a coming conflagration based on its repression of woman-as-subject. Her discussion of three "epochs," including the concluding epoch of the "spirit and the bride," resonates with a theological sensibility. ${ }^{103}$ The subjectivity that would support such a "parousia" remains to be "cultivated." Announcing the cultivation of this subjectivity, which is

102. Bakhtin, Dialogic Imagination, 296-298.

103. Whitford, Philosophy in the Feminine, 33; Irigaray, Ethics of Sexual Difference, 149 . 
woman's subjectivity, is, for Whitford, Irigaray's prophetic task. The construction of a world that overcomes the specific forms of suffering brought into being by the exclusively masculine subjectivity that has dominated western thought and life since the Greeks depends on the creation of a renewed subjectivity for woman. Irigaray's readers encounter her call for this renewed subjectivity.

Irigaray invokes a phenomenon that has not yet come into being, the "not yet" constituting the operative term of utopian possibility. In I Love to You, she is insistent that there are as yet no models of "female identity" since woman's identity as subject has not been cultivated. The "universal" that would sustain a relation of "we," two distinct, non-identical particularities, has not yet come into being. ${ }^{104}$ The "we" relation itself, which would perform the cultivation of the appropriate subjectivities, rests on unanswered questions: "How to unite two temporalities, two subjects, in a lasting way?"105 Ultimately, the questions that two differing subjectivities will address to one another amounts to "Who are you?" and "would remain latent between man and woman, irreducible as they are to one another."106 But this form of intersubjective relation has not yet been cultivated.

"We cannot go along with any of that anymore."107 In other words, there are concrete practical possibilities for the cultivation of a changed relation of man and woman, a different engagement of language, a renunciation of "what has previously been called the love between man and woman" that includes everything so far thought of as natural along with everything so far thought of as cultural. ${ }^{108}$ If these opportunities are taken, if the quality of listening Irigaray describes takes place,

104. Irigaray, I Love to You, $44,48$.

105. Ibid., 111.

106. Ibid., 139.

107. Ibid., 147.

108. Ibid. 
if occasions for the development of two distinct subjectivities are allowed to become productive of individual subjects as well as of fecund relationships between them, it would contribute to the construction of the "we" that would actually be in a position to develop a new form of political life. The different subjects, along with their relationship, and the collective subject to which they contribute, all appear in this discussion to be produced discursively and temporally. They are subjectivities brought into being by their own activity in interaction with the activity of other subjects-in-becoming. While these subjects would, under favorable conditions, come into being in some relationship to what is "inside" them, the - utopian goal would be for them to avoid reproducing the subjectivities that have always already come into being on the ground of woman's exclusion. Those subjectivities, as already noted, are distorted in the case of "man" and officially absent and unintelligible in the case of "woman."109 Irigaray does not propose a political program to bring about a utopian situation. The political proposals she has made have been directed towards the creation of objective conditions that could facilitate the development of communicative exchanges between and among women, toward the objective of the development of a self-consciousness of woman's subjectivity. ${ }^{110}$

Since Irigaray's approach to the existence of "woman" was described by Margaret Whitford as "strategic essentialism," her procedures have been widely discussed under that rubric. As Maggie Berg has noted, however, "strategic essentialism" is a less helpful terminology than it

109. The trace of Adorno's non-identical asserts itself here, since the emergence of a text like speculum attests to the already-existing possibility of the development of a subjectivity that at least permits a recognition of the conditions of possibility for a not-yet-cultivated woman's subjectivity.

110. See however Drucilla Cornell's critique of "sexed civil rights." Cheah et al., ibid. 
seems. ${ }^{111}$ It can all too readily suggest that Irigaray primarily operates by assigning content to the term "woman" in accordance with some essential model of woman's nature, for the strategic purpose of having a way to talk about woman. While there is some truth to this description, Irigaray is more often involved in reminding her readers that woman's subjectivity is "not yet" accessible, "not yet" met, "not yet" cultivated as a passage from nature to culture, "not yet" something that has contributed to the development of a shared world. This makes perfect sense, in her framework, since the basic discursive conditions for the development of the discursive subject that could occupy the position of woman-as-subject have not yet been cultivated. Those discursive conditions would have to make a place for that cultivation. This means, in turn, that they would be a re-designed architecture of the always already operative exclusively masculine phallogocentric symbolic order that is the problem Irigaray's efforts have been addressing all along.

Her point with respect to the cultivation of the subjects of sexual difference is that the discursive possibilities for such a re-designed architecture, a calling into question of assumptions, a putting in place of objective conditions for the development of woman's subject identity, is all possible. In fact, it is more than possible; it is urgently necessary, in light of the disaster that is being cultivated in the name of exclusively masculine culture and its deadly projection of a horizon for being. The sensible transcendental could save humanity from impending disaster, but first we have to conceive of it, and make it. Irigaray's discourse is directed entirely to preparations for that

111. Maggie Berg, "Contradictions": Poststructuralism and Feminism, Signs $7: 1$ (Autumn, 1991) 50-70. 


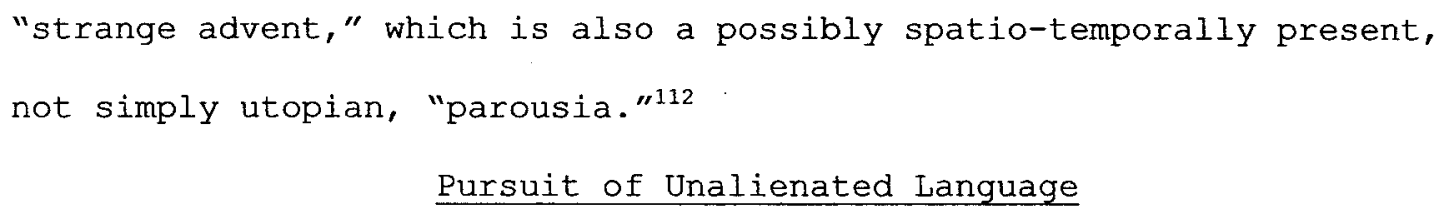

The ultimate utopian possibility of the advent of woman-as-subject is also, for Irigaray, the advent of a new, less alienated human language. The alienation of language stems from the denial and repression of sexual difference, and in particular of the woman beyond the maternal, which forces Man and Woman to use a single language. That language does not serve the subjectivity of Woman, because it does not contain symbols for her relationship to her own origin, or to herself. Irigaray sometimes describes this language barrier as one of "preconstituted" language, in contrast to language that more effectively mediates "fecund" intersubjective communication. Such renewed language communicates more than "a meaning in some way closed," and thereby secures the "becoming" of the relation between two developing subjectivities. ${ }^{113}$ She is under no illusions that this language would be easily developed. She recognizes that it pushes the definitions of language so far developed within the discursive regimes of the western tradition to their breaking point. This language cannot constitute a fixed system of signs in Saussure's sense, it cannot function as a medium of exchange as Lévi-Strauss would understand it, it will not secure a stable relationship between symbols and their assigned contents by means of a governing metaphor according to Lacan's analysis, it cannot be a "shelter" or "house" for being along Heideggerian lines. The communicative language she envisions, which would be adequate to woman's concern with "the relation between two," would have to be constantly renegotiable with respect to meanings, and would require

112. Irigaray, Ethics of Sexual Difference, 19, 147.

113. Irigaray, Way of Love, 24-25. 
sensible rather than simply conceptual points of contact. It could not "consist of something other than the invention of a speaking appropriate only to those who are speaking to each other, at the moment when they are speaking to each other."114 She plays on the Heideggerian distinction between speaking and saying in developing an idea of a saying that would amount to the practice of the new poetics she calls for in Ethics of Sexual Difference. This new poetics recognizes the material, physical character of saying, even one involving words, but also one responsive to the inadequacy of words.

This modified relationship to language necessarily produces a more fluid lexicon and a more fluid relationship of lexical terms to meanings. Its precondition is a "double syntax" that departs from the single syntax of the selfsame symbolic order that now prevails, and that "makes woman's 'self-affection' possible."115 The need for woman's self-affection, that is, for woman's recursive impact on her own experience, is integral to Irigaray's perception of subjectivity as discursive and developmental. If woman cannot "touch" herself linguistically, she cannot develop as subject in discourse that takes her distinct, separate reality into account. Instead, she is eternally separated from that real, and is at best, officially, constructed as a non-subject through the operation of the single, phallogocentric syntax that rather carefully covers up the traces of the possibility of a subjectivity different from its own.

The problem of language for Irigaray is not the same as for Adorno. The problem is not that language as a physical marker of meaning fails to achieve identity with what it denotes, and so fails as a medium of absolute knowledge. For Irigaray, the problem arises prior to the

114. Ibid., 27.

115. Irigaray, This Sex, 132. 
recognition of inadequacy of language, which comes to be attributed to the "body of language," its participation in a "nature" that is obsessively feminized and repressed. It resides in the incommensurability of the two subjectivities that need to come to expression, self-awareness, and intersubjective relationship through language. Nevertheless, she recognizes the problematic Adorno identifies, and spins it out in relation to Heidegger's bias in favor of the word, the logos. Where Heidegger wants to accord priority to the word, Irigary - here, a congenial companion for Adorno -- "would think rather. . about the secret of the thing, or of the other, of their resistance to the logos."116 For Irigaray, as for Adorno, a specific quality of encounter with "the thing" or "the other," with "the concrete," can challenge the adequacy of existing language and concepts. The ultimate wellspring of Irigaray's utopian possibility is that of a real that is communicable, and that can communicate its resistance to its own exclusion from language.

Adorno, however, sees the figure of unalienated language in something like Benjamin's Adamic "names," at one with their objects. Irigaray treats "naming" as a threat, equivalent to a closed context of language. This closed context of language is part of the apparatus that excludes woman's subjectivity. This is one of the points where Irigaray's relentless reference to sexual difference hits pay dirt. What would have induced anyone to have seen in the text of Genesis 2, in which the Man Adam names Woman without any explicit recognition of her subjectivity, on the basis of an interior identity with Man ("bone of my bones and flesh of my flesh") a paradigm for an unalienated use of language? Irigaray could counter with the text of Genesis 3 as the immediately available illustration of where such naming practices end

116. Irigaray, Way of Love, 29. 
up: expulsion from paradise and the inscription of patriarchy in society and language.

There are two issues with this picture of language for Irigaray. One is the familiar problem of who decides what a word, a phrase, a sentence means, and how that decision comes to be reached. The other is the presumption of the adequacy of a static word to continue to function in a context of becoming. The imposition of language itself suggests that what it refers to is a never-changing context of meaning. Irigaray's utopian discourse depends on recognizing that words may mean different things to different people, in particular as an illustrative example to men and women; that they may register different experience, and that communicating this difference in experience may become important. Reducing everything to a single common experience, which may in the end not be common at all, does some violence to the possibility of genuine communication and the production of something new. So Irigaray is concerned to hold open the possibility of encountering something or someone different. She connects the problem of gender to the problem of the divine-human relationship, another significant area of attempts at communication across a line of difference. These two lines of difference stand for each other, engage in sympathetic resonance, reflect one another, such that the inability to imagine the transcendent female stands for the inability to negotiate both divine-human difference and mutual transcendence, and the inability to negotiate gender difference.

Moreover, language for Irigaray is physical, and is the physical trace of something more elementally constitutive of the proximity that needs to be built and cultivated between the two of sexual difference. At the heart of her intense disagreement about language with Heidegger in The Way of Love is what she reads as Heidegger's removal of language 
from "its carnal touching" in a way that is always already dystopian. "No more not-yet-manifested, still-to-come animating the quest" and eliminating the possibility of becoming a subject who is not simply a reflection of the always already constituted world that is always already known in and by this language. ${ }^{117}$ Heidegger's approach, with which she disagrees, would make the "language" of poetic language more determinative than the "poetry," and to foreclose the possibility of the new poetics she advocates.

Irigaray's emphasis on the physical dimension of language links her reflections on language to Adorno's and points towards Agamben's. For all of these thinkers the physical dimension of language, often overlooked, is critically important. The physical dimension of language comes to be a place where the ineradicable involvement of what might be called matter, nature, or bodily life in every effort and instrument by which people undertake the formation of that matter comes to awareness, albeit with some initial difficulty. That involvement, in turn, constitutes the ineradicable trace of what refuses to stop demanding utopia.

Admittediy, sometimes that demand is silent. For Irigaray, silence is an integral component of language and of speech, and a particularly fertile one. Her project from its first manifestation in Speculum has sought to render audible the meanings that inhabit the spaces and silences of dominant discourse. The execution of this difficult project is one aspect of what is termed here Irigaray's utopian discourse, a discourse that represents utopian possibility as present in the appearance of impossibility itself. Another use of silence, however, emerges in Sharing the World. This use is more directly productive of utopian imagination. It depends upon the way silence constitutes a

117. Ibid., 34 . 
welcoming of what has not yet occurred or been understood. This welcoming amounts to a direct acceptance of what has been identified here as utopian possibility, encountered in the unknown. Speaking or saying would close the door to this possibility, by labeling and forming it before it emerged. The [utopian] welcoming with which Irigaray concerns herself here "requires an availability for that which has not yet occurred, an ability and a wanting to open ourselves to the unknown, to that which is still unfamiliar to us and, in a sense, will always remain unfamiliar."118 An initial silence and listening, rather than finished language, that forms a desire for an encounter with difference that can also be an encounter with self, emerges as an indispensable element of the apparatus of the language that promises the human possibility on behalf of which Irigaray writes. This possibility deserves to be recognized, according to the criteria advanced here, as utopian.

\section{Treatment of Space and Time}

The practice of language Irigaray advocates has a distinctive relationship both to space and to time, or in Irigaray's terms, "temporality." Irigaray's talk about new ways of relating space and time is part of her representation of the possibility generated in the relation of sexual difference. She portrays the "space between two" as the site of a new, utopic form of exchange. This exchange is not barter: it is not the trade of objects for other objects; it is an exchange of interiorities, and an articulation of temporalities. Irigaray recognizes as "the western paradigm" an understanding of space and time, in relation to subjectivity and objectivity, one in which "[t]ime becomes the interiority of the subject itself, and space, its

118. Irigaray, Sharing the World, 18. 
exteriority."119 The exchange of temporalities she envisages is, then, an exchange of interiorities, of subjectivities, which are non-identical, non-hierarchical, and also located "outside" one another. That is, they are transcendent vis-à-vis one another, without being supra-sensible or necessarily incommunicable. In this place of exchange, which is a place of possibility, a new cultivation of the human movement from nature to culture can take place.

The western paradigmatic understanding of space and time is not the problem. That paradigm becomes problematic in the context of the exclusively masculine subject. ${ }^{120}$ Irigaray's images for the problem it becomes are images of closure: space curves in on itself; it makes for an unavoidable "harm" in moving from one epoch to another, since time itself has congealed in this space. ${ }^{121}$ The exclusive subject projects, the spirit congeals, the world closes spatially, and exteriorized space can no longer keep pace with the temporality of the interior. It becomes oppressive. This scenario is Irigaray's version of the sociological paradigm of alienation, the activity of human beings coming to appear to them as alien, almost natural forces beyond their control.

The space so created fails to allow adequate or appropriate room for wonder, the first of all the passions. Wonder could provide for a creative relation to what might be new, not yet contained in the known - conceptualized - world. Instead, "[t]he passions have either been repressed, stifled, or reduced, or reserved for God. Sometimes a space for wonder is left to works of art. But it is never found to reside in this locus: between man and woman."122 Securing a space for wonder in

119. Irigaray, Ethics of Sexual Difference, 7.

120. Irigaray, Sharing the World, ix.

121. Ibid.

122. Irigaray, Ethics of Sexual Difference, 13. 
this place of difference, where "each sex, body, and flesh" will need to inhabit in a shared or articulated way, requires a change in the relationship of time to space, according to Irigaray. In particular, it "presupposes a memory of the past, a hope for the future, memory bridging the present and disconcerting the mirror symmetry that annihilates the difference of identity."123 In other words, space must be made into a "housing" or safeguarding of non-identical temporalities, temporalities that can communicate and influence one another. This is a change from a conception of space as a stage for a univocal time. "Perhaps we are passing through an era when time must redeploy space? A new morning of and for the world?"124

Irigaray's treatment of time, of "temporality", has become increasingly central to her understanding of the cultivation of the intersubjective relationship in recent work. This relationship is paradigmatically between man and woman, but by extension between the subjects of enunciation: between "you" and "I," between "us," even between "I" and "he" or "she."125 The constituents of any "us" or "we" each need both their proper subjectivity, recognized as such, and the objectivity proper to this subjectivity. That objectivity would not be identical to one that has been assigned to one or the other differentiated subject, whether on the grounds of conventional readings of physical morphology or for some other reason, by the culture, tradition, language, perception, narrative in which the subjects come to be. In The Way of Love she discusses this "temporality" specifically as a commentary on the balance of "making" and "letting be" that is required in a genuinely intersubjective relationship between two different subjects, neither of whom can be reduced to an instance of

123. Ibid., 18.

124. Ibid.

125. Irigaray, Sharing the World, 102. 
"the same." In the imagined relationship, "a temporality, which the sovereignty of technology endangers, can be reconstituted."126

The destruction of temporality in technique or technology, predictably, stems from a systemic exclusion of sexual difference. In the technological situation, technique or technology treats something as an object for the exclusive purposes of a subject understood to be both singular and exclusive. The subject encounters every object of knowledge as something at his disposal, available for the purposes of an activity of making that is predetermined by the thoughts, purposes, or projects of this subject. This making takes place without a limit, other than that set by the selfsame subject's projected horizon; there is no "return to self" in this creative activity and, above all, no return to self understood as a subject in relation with another subject. In this context, the application of technique or technology - technē becomes exclusively a form of domination which "destroys temporality because it is no longer structured by a subject."127

The temporality that would be structured by the human subject, the temporality that would represent a real mediation of nature and culture, would necessarily be a temporality created or fabricated between the two subjectivities that make up humanity, the open universe of the human subject. This temporality then stands in implicit contrast with one that is, for instance, governed by the linear life story of a single subject, including that of an overarching collective History. The creation of an alternative temporality does not - presumably cancel the operation of historical conditions in or on the constitution of individual subjects. Irigaray does, however, seem to be suggesting that such subjects could develop an intersubjectivity that transforms

126. Irigaray, Way of Love, 125.

127. Ibid., 126 . 
the operation of history. The relationship between two different subjects, especially sexually different subjects, would not be reduced to instances of the same on either side. Instead, they would be encountered in their irreducible difference. That irreducible difference is governed by the temporality of the "unfolding of history," or the "playing out of pre-established conditions," or even the unfolding of a script presented in any existing philosophical text (e.g., a Hegelian script of recognition, or a Heideggerian script of going out of oneself and returning to oneself). Two such irreducibly different subjects establish between themselves a singular temporality governed by a "duration. . . of which human consciousness is the artisan," the material for which is two distinct pasts, presents, futural hopes, and the future which represents that which has not yet become between them.

Irigaray's "artisanal" picture of intersubjective temporalities in relation stems from her understanding of the development of subjectivity itself. These distinct subjects are temporal. What they "are" is time. But the temp-oral-ity of the one is not identical to the temp-oral-ity of the other. These two differing temp-oral-ities have to enter into relationship, externally in the coordinated making of a world in which the two may share, and internally in the auto-poietic making of an interior world "appropriate" to the reality of each. The making of this interior space or place follows the encounter with the differing subject. The construction of the world, and the construction of the interiority that can open on the world, happens in a way "back to front." The world precedes the development of the subject's interiority. The articulation of different temporalities occurs as these temporalities emerge, through their relationship to one another, 
and to the world they construct between them. They are temporalities that have "not yet" come into being.

Irigaray's "woman-as-subject" appears, in this sense, as an almost messianic figure. That is, her emergence as a concrete, real subject would initiate the promising possibilities for genuinely intersubjective relations that make up Irigaray's utopian scenes. The arrival of the Irigarayan woman-as-subject would mark a form of salvation for a way of life that is destroying itself and its human practitioners. The preconditions for that arrival exist now. In fact, they have always already existed; they have been systematically denied, suppressed, or repressed. They can, however, be cultivated; the wretched state of the present world demonstrates that they need to be cultivated.

The fruits of whatever politics that might be developed in this idyllic intersubjective context would presumably ripen in the future. Utopia appears in Irigaray's impressionistic account as the consequence of future people in future intersubjective relations, towards which activity in the present could contribute. She provides some desiderata, which people in the present might embrace. The development of the objectivity, and subjectivity, appropriate to authentic human culture is work to be undertaken. Irigaray's descriptions lead her readers to imagine it could be a pleasant task on the whole, difficult as it may prove to be because of its radical difference from accustomed, fundamental, habits and practices of mind and behavior.

\section{Unresolved Questions}

What is absent from Irigaray's scenarios is any sense of continuing conflict, and how that might affect the unfolding of the development of subjectivity between-two. Irigaray's work does not address, though it may be argued that it performs, the cultivation of the wish or the will, 
the desire, to undertake the needed cultivations she describes. As

Patricia Huntington has observed, Irigaray, like Heidegger,

incorporates a significant element of voluntarism in her ethical

recommendations. That is, she does not adequately address the question

of what promotes, encourages, or prepares the way for ethical

cooperation with the insights of her analysis. ${ }^{128}$

This reliance on present voluntarism is an undeniable weakness in

her work. If, to adopt Margaret Whitford's metaphor, Irigaray does

indeed act as a contemporary prophet, her later work may have more in common with street-corner preaching than with critically targeted

evangelism. Practically speaking, this approach may not be the best way to cultivate the collective energies for which the development of a renewed subjectivity calls. It seems to fly in the face of her own account of the development of subjectivity, the recognition that objective features of how human beings live, talk, and think, related to concrete conditions of existence, deeply affect the interior architecture of the subject of any potential praxis.

Irigaray's critiques of the phallogocentric order indicate that she is aware that the smoothly functioning, respectfully intersubjective co-creation of a shared world lived in proximity with the other-assubject has not been the direction in which human culture has developed so far. Nevertheless, her account seems to assume reasonably good will all around, though inarguably bad exegesis in some quarters. Her scenarios do not extend to those cases in which a subject-in-the-making runs up against an inability to listen, a misguided effort to close the

128. "Her work abstractly leaps from a limited textual practice aimed largely at consciousness raising and rejuvenation of an autonomous social desire to a material specification of needs. It rests upon a flawed premise that an abstact textual practice suffices to establish ethical humility among women who occupy axes of power relative to one another." Huntington, Ecstatic subjects, 250 . 
context prematurely, as represented by Heidegger's insistence that there is "nothing" where words are missing. Irigaray does not discuss what might happen, in her model, when one meets up with a blind and indifferent other, or a naughty and flighty other, or with an other who has cultivated the aesthetics of cruelty, or engineered the perfection of destruction. If utopia is blocked off by possibility, these are some of the possibilities that have blocked its way in times past, continue to block the way today, and appear to be well-provisioned to continue to stand in the doorways and block up the halls in the future. With that in mind, whether Irigaray's analyses constitute a compelling macropolitical analysis remains open to question. She proffers the hopeful vision that the cultivation of these qualitatively different human relationships at the level of between-two will have a cumulative, "leavening" impact on the larger cultural formation, "possibly at the level of the family and community."129 This vision, in its broad outlines, is not new; it has been the hopeful vision of religious communities and religious teaching for a long time: change the self, change the world.

Irigaray's key change, from "the self" to the "sexuately different selves," may face prospects for change substantially similar to those encountered by those other programs of thought and practice. That dystopian complaint, however, probably does not disqualify Irigaray's fundamental point. On her analysis, an unchanged humanity - a humanity unleavened in the way Irigaray suggests - will be incapable of creating a remarkably new kind of political world. Her task has been to point out the direction in which the possibility of such a new kind of worldcreation might lie, and how that direction might be approached. The

129. Irigaray, Sharing the World, 59. 
task of working out the divinity in the details of the approach itself she has left as an exercise for her readers.

Like Adorno, then, Irigaray appears as a creator of a discourse that calls for a specific conceptual and practical change in its readers. She speaks as if in a dream about a way of life that might be being lived, in another space and time different from, yet remarkably similar to, the one in which her readers find themselves. She seeks to awaken a desire for that way of life, and to point in the direction of the practices - conceptual, linguistic, interpersonal - that would cultivate subjectivities with the ability to dream these dreams more lucidly, with more precision and determination. Her texts, too, call to and act to equip a subject of [utopian] possibility.

Irigaray presents the task of becoming this subject as the indispensable work of art that each human must undertake, on pain of "losing its humanity." In her conclusion to The Way of Love, she describes this material and aesthetic task as one that verges on something that has always been assigned to religion:

Surpassing the matter that [the human] is in view of its nullification should not be a human's undertaking, but rather transforming this matter so far as to make it a work of art, to transubstantiate it into a more subtle, spiritual, even divine, matter. To illuminate it so that it enlightens he, or she, who gazes upon it, who contemplates it. ${ }^{130}$

That as-yet-unrealized subject would genuinely, if obscurely, radiate what might even be a messianic light.

130. Irigaray, Way of Love, 174. 
CHAPTER IV

HALO

Introduction

Giorgio Agamben is a theorist given to recurrent motifs. Many of these are well-known, among them bare life, the structure of an exception, profanation, and potentiality. Another of these recurrent motifs is the halo. In The Coming Community, Agamben presents st. Thomas Aquinas' treatment of the halo as an inessential but significant supplement to blessedness. The halo signals an intelligible particularity within a universal condition, marking a "zone in which possibility and reality, potentiality and actuality, become indistinguishable," and figures "the tiny displacement that every thing must accomplish in the messianic world." In The Idea of Prose, the image of the halo serves, similarly, to evoke something nearly ineffable, but at the same time completely visible or communicable, albeit outside of language. The singular nearness disclosed in the image of the halo is evoked more linguistically in Agamben's conclusion to The Time That Remains. There, it is the messianic word of faith that "bears witness to what, unexpressed and insignificant, remains in use forever near the word."2 Agamben's halos, it would seem, glow with messianic light.

1. Agamben, The Coming Community, 56. According to a rabbinic story, the messianic world will differ from this world by only a tiny displacement.

2. Agamben, The Time That Remains, 137. 
Showing how the messianic light of the halo discloses utopian discourse in Agamben's texts is the central task of this chapter. It demonstrates that Agamben's writing, like that of Adorno and Irigaray, appeals to a subject of utopian possibility. Agamben's writing does this by addressing itself to readers who are themselves bearers of an almost metaphysical potentiality. The model of subjectivity he advances differs significantly from that of the rational subject of the humanities; for that reason, on Agamben's analysis, it is positioned to challenge the pervasive nihilism of contemporary culture.

This thesis may not be met with universal agreement. Agamben has most frequently been identified as a thinker of "passivity." ${ }^{3}$ He has also been identified as a utopian thinker in the pejorative sense; Mark Mazower portrays his thought as radical political despair leading to an embrace of a purely passive "dream of ultimate redemption, some new 'beautiful life.'"4 Alternatively, Carlo Salzani has countered such criticisms by assessing Agamben's efforts in The Coming Community as radically anti-utopian. ${ }^{5}$

Sustained consideration of Giorgio Agamben's utopian discourse has not been the central matter in studies of his thought. Giorgio Agamben is "famous," and controversial, but that fame and controversy have come primarily as a consequence of the publication of his challenging Homo

3. See in particular Wall, ibid.

4. Antonio Negri, "The Ripe Fruit of Redemption," trans. Arianna Bove, Generation Online, http://www.generation-online.org/t/negriagamben.htm, May 24, 2010, a translation of "Il frutto maturo della redenzione," Il Manifesto (Rome) July 26, 2003, 21; Andreas Kalyvas, "The Sovereign Weaver: Beyond the Camp," in Andrew Norris, ed., Politics, Metaphysics, and Death: Essays on Giorgio Agamben's Homo Sacer (Durham: Duke University Press, 2005); Mark Mazower, "Foucault, Agamben: Theory and the Nazis," boundary 2 35:11 (Spring, 2008) 2334,34 .

5. Carlo Salzani, "Quodlibet: Giorgio Agamben's Anti-utopia," a paper presented to the $9^{\text {th }}$ International Conference of the Utopian Studies Society, 35 July, 2008, University of Limerick. 
Sacer series. ${ }^{6}$ Some but not all of this critique has focused on the extreme claims Agamben makes about the structure of contemporary politics and political institutions. His assertions about the fundamentally totalitarian and punitive structure of western biopolitics - the concentration camp is the "new biopolitical nomos of the planet," and "[t]oday it is not the City but rather the camp that is the fundamental biopolitical paradigm of the West" - provoke outrage at many points of the political spectrum. ${ }^{7}$ He has been charged with opportunism, sensationalism, and illegitimate aestheticism in linking the horror of the Nazi death camps to paradigmatic western state politics. ${ }^{8}$

His reputation for a despairing, fatally utopian or politicaltheological political passivity seems to be fed most directly by his implicit rejection of political strategies that make control of the state an objective. ${ }^{9}$ Instead, Agamben paints a picture of the contemporary state as an institution that is lethal down to its original conceptual foundations. Making any use of an institution as intrinsically inimical to life as the biopolitical state would call for its profound rethinking and retooling, and may even then be inadvisable.

6. Durantaye, ibid., 7-11. The titles in the Homo Sacer series include Homo Sacer: Sovereign Power and Bare Life, State of Exception, Remnants of Auschwitz: The Witness and the Archive, and The Power and the Glory. Early critical works on Agamben in English focused primarily on this aspect of his work, including Norris, ed., ibid., Calarco and DeCaroli, ibid., and the winter, 2008 issue of South Atlantic Quarterly dedicated to Agamben's work. Catherine Mills's comprehensive introduction was the first work in English to focus on Agamben and include his earlier literary and aesthetic work. See Catherine Mills, ibid.

7. Giorgio Agamben, Means Without End: Notes on Politics, trans. Vincenzo Binetti and Cesare Casarino (Minneapolis: University of Minnesota Press, 2000), 45; Homo Sacer: Sovereign Power and Bare Life, trans. Daniel Heller-Roazen (Stanford: Stanford University Press, 1998) 181.

8. See Durantaye, 213-214, 217-219; Dominick LaCapra, "Approaching Limit Events: Siting Agamben" in Giorgio Agamben: Sovereignty and Life, eds. Matthew Calarco and Steven DeCaroli (Stanford: Stanford University Press, 2007) 126-162, J.M. Bernstein, "Bare Life, Bearing Witness: Auschwitz and the Pornography of Horror" Parallax 10 (Winter, 2004) 2-16; Antonio Negri, "The Discreet Taste of the Dialectic," in Calarco and DeCaroli, 109-125.

9. Slavoj Žižek, In Defense of Lost Causes (London: Verso, 2008), 338. 
The challenge Agamben's work poses to the repertoire of political forms and strategies may be another reason for his reputation as a political quietist. That reputation itself is an index of the difficulties involved in imagining a politics oriented otherwise than towards the state and its sovereignty.

The focus here is on showing that Agamben's work in fact articulates what could reasonably be called a utopian assessment and plan, and so constitutes utopian discourse. As will become clear, Agamben avoids explicitly utopian language. Instead, he issues repeated calls for bringing dystopian situations to an end. Politics needs to "put an end to the civil war that divides the peoples and the cities of the Earth;" humans need to understand the structure and operation of the "anthropological machine" that distinguishes animal and man [sic] "so that we might, eventually, be able to stop them;" "we" must succeed in understanding how we ourselves can accept self-absorbed inattention to omnipresent cruelty and horror as "human," and put an end to that practice, or "there will never be hope."10 The hope he pursues is that which yields the concrete possibility for a common human life with an immunity to totalitarian capture.

Agamben is not only famous and controversial, he is prolific. Each of his many books is individually trim, though not strictly speaking concise, and repetitive. Catherine Mills has called "Agamben's œuvre . . a complex recursive exercise" that is less a system than "a densely interconnected conceptual web."11 In fact, Agamben's work as a whole constitutes something like the "paratactic text" that was Adorno's textual ambition, in which the enunciations lie, severally and

10. Agamben, Means Without End, 35; The Open: Man and Animal, trans. Kevin Attell (Stanford: Stanford University Press, 2004) 38; Remnants of Auschwitz: The Witness and the Archive, trans. Daniel Heller-Roazen (New York: Zone Books, 2002) 26 .

11. Mills, ibid., 2. 
collectively, equidistant from the center and relate to it as the radial threads of a spider's web. That is, Agamben seems to have extended Adorno's model for a single text to multiple works.

The paratactic or radial quality of Agamben's texts, or text, poses a challenge for consideration of the utopian dimension of that work. Although a case might be made that all of this work bears on the central question of utopia, a detailed consideration of Agamben's entire work would exceed the scope of this study. This chapter will not attempt to reproduce the recent studies that deal critically with Agamben's entire oeuvre in general. ${ }^{12}$ Too restricted a consideration, however, will not do justice to those recurrent themes that are vital to understanding the utopian trajectory of Agamben's work. This chapter strives to pursue a middle way. It presents a more extended consideration of those works whose utopian dimension lies closest to the surface, and treats the background of those utopian dimensions by a judicious consideration of Agamben's other relevant texts as the issues they address arise in the analysis.

Because Agamben has written so much, readers may appreciate a rationale for the choice of texts to be considered in most detail here. This study has focused most centrally on The Coming Community, The Time That Remains, and The Open. The Coming Community and The Time That Remains are the full-length texts that deal most directly with issues of desirable or in Agamben's terms "messianic" community, its relationship to the transformation of the subject, and the understanding of space and time relevant to the production and 1 ife of such a community. A third text, The Open, is especially significant for the purposes of this study because it deals specifically with the structure of the human subject in contrast to animal nature. The

12. See Mills, ibid.; Durantaye, ibid. 
reconciliation of the human with nature is one thematization of utopian hope. ${ }^{13}$ From this perspective, The Open is directly, thematically relevant to utopia. Furthermore, this text includes Agamben's most explicit treatment of gender. This makes the Open of particular interest both with respect to the general question of utopia, and to the specific question of the relationship of Agamben's utopian discourse to that of Irigaray.

This focus explicitly treats as secondary those texts of Agamben's that have made him so famous and controversial in recent years. Readers who are familiar with those texts will still find much to recognize here, however. Agamben's characteristic insights and preoccupations emerge everywhere in his work. So, for instance, divisions of divisions, the structure of an exception, or the construct of a critical experimentum linguae continue to play a significant role in the texts considered here.

The goal here is to demonstrate the connection of these characteristic preoccupations to utopian concerns. The chapter approaches this task as follows. The first section discusses the dystopian or "nihilist" situation against which Agamben's philosophical project unfolds. The second section summarizes Agamben's expansive philosophical project, through a discussion of key concepts. The role of utopian content in that project receives additional attention in the third section. Finally, individual sections discuss the way Agamben uses textual form and the approach he takes to language, his unique

13. Seyla Benhabib, Critique, Norm and Utopia: A Study of the Foundations of Critical Theory (New York: Columbia University Press, 1986); Richard Wolin, "Utopia, Mimesis, and Reconciliation: A Redemptive Critique of Adorno's Aesthetic Theory" Representations 32 (Autumn, 1990) 33-49; Martin Ludtke and Ted R. Weeks, "The Utopian Motif is Suspended: Conversation with Leo Lowenthal" New German Critique No. 38 (Spring-Summer, 1986) 105-111. 
treatment of the subject, and his construction of space and time as part of the construction of the subject of utopian possibility.

A Preliminary Note on Gender

Giorgio Agamben presents to some readers the dismal and dismaying picture of a living philosopher who deals explicitly with ideas that are profoundly engendered without ever articulating an explicit concern with gender. Nichole Miller exemplifies the approach taken by other feminist critics, in taking Agamben to task for the gender-blindness of his reading of one of the Lays of Marie de France in Homo Sacer, despite the relevance of gender for the concrete characterization of the sacred man (or woman). ${ }^{14}$ Catherine Mills notes similar concerns with Agamben's androcentric language and myopic inattention to the engendered content of key areas of his work, and goes on to raise the question of whether Agamben's very conceptual framework makes it meaningless to raise and pursue questions of gender and other forms of difference. ${ }^{15}$

Other readers with feminist sensitivities and commitments discern in Agamben's thought potentials for addressing splits and exclusions deeply embedded in the western philosophical tradition. The most recent case in point is Ewa Ziarek, who reads Agamben explicitly through a lens constructed.by Irigaray, and who recognizes in his discussion of potential and subjectivity a way through the exclusion of woman-as-

14. Nichole E. Miller, "The Sexual Politics of Pain: Hannah Arendt Meets Shakespeare's Shrew," Journal of Cultural and Religious Theory 7:2 (Spring, 2006) 18-32; see also Astrid Deuber-Mankowsky, "Homo Sacer, das blosse Leben und das Lager Anmerkungen zu einem erneuten Versuch einer Kritik der Gewalt," Die Philosophin, No. 25 (2002), 95-114; Penelope Deutscher, "The Inversion of Exceptionaity: Foucault, Agamben, and 'Reproductive Rights," South Atlantic Quarterly 107:1 (Winter, 2008) 55-70.

15. Mills, Agamben, 115; Catherine Mills, "Playing with Law: Agamben and Derrida on Post-Juridical Justice," South Atlantic Quarterly 107:1 (Winter, 2008) 15-36. 
subject from language. ${ }^{16}$ The approach taken here is most in tune with Ziarek's reading. Agamben's writing and insights are not "feminist," but this chapter argues, in contrast to Mills, that feminist thinkers can make good use of them.

In this connection, readers need to know that Agamben's English translators have unanimously translated Agamben's I'uomo as man, without discussion. So, for instance, Agamben's Italian work L'aperto: I'uomo e I'animale, which is in German, Das offene. Der Mensch und das Tier, greets its readers in English as The Open: Man and Animal.

Given the concerns already noted by Irigaray about the disappearance of Woman, the need to incorporate into philosophy a sensible transcendental that stems from recognition of the two-ness of humanity, and the presence of transcendental boundaries that affect both language and dwelling between human genders, it is not possible to believe that this usage is simply insignificant. We will need to pay attention to those places and ways that this feature of language, both original and in translation, brings with it certain presuppositions or occlusions that operate in the thinking presented here. It seems unlikely to be a coincidence, for instance, that in Agamben's textual world, where "man" contrasts with "animal," becomes "sacer," has language or lives politically, "the woman" appears, when she does, in advertising and pornography. ${ }^{17}$ or that her appearance invariably signals utopia.

16. Ewa Plonowska Ziarek, "Feminine 'I can': On Possibility and Praxis in Agamben's Work," Theory and Event 13.1 (2010) Project MUSE, University of Louisville Library, Louisville, KY, http://muse.jhu.echo.louisville.edu/, (accessed March 28, 2010).

17. See e.g., Agamben, "Dim Stockings," The Coming Community, 47-50; Giorgio Agamben, "The Idea of Communism," Idea of Prose, trans. Michael Sullivan and Sam Whitsutt (Albany: SUNY Press, 1995) 73-75. 


\section{Dystopian Vision - Spectacular Society}

Agamben claims repeatedly that contemporary humanity is undergoing a trial of nihilism. This problem of nihilism finds expression first of all in art, reveals itself most profoundly in the metaphysics of language, and ultimately concerns ethical and political life. ${ }^{18}$ Agamben sees this present nihilistic situation largely through the lens provided by the Situationist International and in particular by Guy Debord's assessment in The Society of the Spectacle. ${ }^{19}$ He conveys his explicit agreement with Debord in Means Without Ends, calling Debord's books "the clearest and most severe analysis of the miseries and slavery" of "the society of the spectacle in which we live."20 Agamben extends Debord's critique with his assessment of the roots of contemporary nihilism in western culture and society, in particular in the text of Language and Death; Agamben sees this nihilism played out in the lethal versions of contemporary biopolitics that are the central concern of his Homo Sacer books.

Guy Debord's analysis of "the society of the spectacle" raises the definitive challenge to hopes that culture might provide a base for critical consciousness and awareness, independent of late capitalist relations of production. Debord's text describes a situation in which all cultural channels of communication tend to reproduce an alienated mode of consciousness beguiled by the commodity and its spectacular appearance, and correspondingly incapable of perceiving that which "does not appear." His analysis dovetails with Adorno's and

18. Agamben, The Man Without Content, 102; Language and Death; "Marginal Notes on Commentaries on the Society of the Spectacle," Means Without End, 7389.

19. Guy Debord, The Society of the Spectacle, trans. Donald Nicholson-Smith (New York: Zone Books, 1995); "Comments on the Society of the Spectacle," trans. NOTBORED!, http://www. notbored.org/commentaires.html (accessed December 9, 2009).

20. Agamben, Means Without End, 73. 
Horkheimer's account in Dialectic of Enlightenment, bringing their assessment of the culture industries into the late $20^{\text {th }}$ century. The picture Debord presents of reality being rendered culturally and politically ineffective by being rendered inapparent echoes Irigaray's analysis of the position of woman in speculum, as well.

Debord deploys a number of epithets in an effort to communicate the reality of the spectacle. "The spectacle is capital accumulated to the point where it becomes image." It is "money for contemplation only." It is "a permanent opium war waged to make it impossible to distinguish goods from commodities..." and an "augmented survival" from genuine satisfaction. ${ }^{21}$ Ultimately, the spectacle is a life-size, threedimensional, animated, ideological representation of "the social totality" which corresponds to and reinforces the self-evident appearance of the form of alienated production and consumption in the world produced by the operation of late capitalism and its history. That representation occludes both the possibility of achieving an alternative form of life, and the possibility of the different form of human consciousness that would be interested in the pursuit of such an alternative.

Debord includes in his remarks a lengthy discussion of time, and the relationship to time, as part of the progress of the spectacle. According to Debord, capitalism subordinates traditional cyclical, mythic time to the uniform, linear time of the production process; this linear time becomes the specific time of the spectacle, in which images are consumed, and in which the image of time itself as something to consume is endlessly re-displayed. ${ }^{22}$ He further identifies the transformation of time as one of the areas in which any resistance must

21. Debord, Society of the Spectacle, $24,33,30$.

22. Ibid., 53 . 
intervene. In asserting the demand "to live the historical time that it creates, the proletariat discovers the simple, unforgettable core of its revolutionary project." 23

However, contemporary resistance cannot assume outmoded historical forms, such as that of the militant working class party. The integrated spectacle makes resistance appear either easy, or counterproductive. Resistance appears to be a matter of buying a progressive form of some commodity, like free-range eggs or fair-trade coffee; alternatively, it appears to be a matter of shredding the entire social and economic fabric, hardly a prescription for negating suffering. Genuine options for critical consciousness seem to vanish, along with visible alternatives to existing social organization.

The spectacle poses a stringent challenge to utopian imagination. In 1967, Debord was capable of articulating a covert anti-spectacular sentiment, saying that "a critique capable of surpassing the spectacle must know how to bide its time."24 Two decades later, observing what he termed the "integrated spectacle," Debord described a society already in the grip of an ever-wider, totalizing closure of alternatives for thought and action:

The empty debate on the spectacle -- that is, on the activities of the world's owners -- is thus organized by the spectacle itself: everything is said about the extensive means at its disposal, to ensure that nothing is said about their extensive deployment. ${ }^{25}$

This prevailing situation seems in some sense intentional. Debord characterizes it as "ambitious," and says "the greatest ambition of the integrated spectacular is still that secret agents become revolutionaries, and that revolutionaries become secret agents." ${ }^{26}$ In

23. Ibid., 43.

24. Ibid., 220.

25. Debord, Comments, III.

26. Ibid., IV 
other words, its ambition is to confound and render futile at the level of revolutionary consciousness any activities associated with revolutionary aims. Within the feverish and conspiratorial picture of society painted here, the spectacle aims to control all activities of direct resistance to its totality. This direct control, and therefore a priori nullification, of resistance constitutes yet another step in the progress of rationalized unreason analyzed in Dialectic of

Enlightenment.

At the same time, the spectacle asserts its official immunity to critique. "All crimes and offenses are effectively social. But of all social crimes, none must be seen as worse than the impertinent pretension to still want to change something in this society . . ."27 Moreover, Debord points out that even those who want to challenge the dominance of the spectacle will, perforce, use its "syntax" and "vocabulary." His meaning here seems to follow a familiar logic of visible resistance. Protest movements are said to become successful when they gain media recognition, visibility, and have their demands, aims, and rationales disseminated by media channels. Successful protest means appearing. But success, understood as visibility and credibility, must be bestowed by and within a system that bestows visibility and credibility precisely, in Debord's analysis, upon statements and images that are taken out of context, de-contextualized, manipulated, and used as the substance of 1 ies. ${ }^{28}$ When efforts to resist, or to pursue change, find themselves unable to pursue their aims in any way other than one which reinforces existing social relations and forces, then people experience their dealings with the spectacle as dealings with reality

27. Ibid., IX.

28. The classic spectacular analysis of spectacular resistance is David $\mathrm{J}$. Garrow, Protest at Selma: Martin Luther King, Jr. and the Voting Rights Act of 1965 (New Haven: Yale University Press, 1978). 
itself. What appears as reality is an effective absence of opportunities for resistance to the way things are [in the spectacle], along with opportunities for alternative imagination, and alternative praxis.

The spectacle functions as a mode of legitimation by presupposition, precluding debate or decision on a range of fundamental questions. ${ }^{29}$ Many consequential administrative decisions have been made in advance. The managers and decision makers who execute them are absolved of responsibility for the consequences of actions they take with a sense of having no alternative, as they put specific economic policies into place, take concrete production and process decisions, and ignore the value judgments implicit in what appear to be straightforward mathematical calculations. Rationality, defined "in use" as what supports the strategic objectives of the corporation, justifies technicized business practice. Corporate strategic objectives always, whether or not stated in the mission statement, include making profits and "being responsible to the shareholders," a fiction that guides decision making whether or not its results prove effective in the longer run. ${ }^{30}$ The system that develops on the grounds of these presuppositions acquires the unchangeable and unquestionable appearance once reserved for "nature."

The fact that alternatives are available, at least logically, and that whatever can be done also can not be done, if not always vice versa, remains officially and generally inapparent. If there are faint shadows of hope, they are the actual, though obscure, deficiencies of this total situation itself. For instance, as Debord points out in his

29. Ibid., XII.

30. For example, decisions justified in this fashion may prove mistaken and costly even from this narrow standpoint, without calling the compulsory logic into question more generally. 
Comments, "To this list of the triumphs of power we should, however, add one result which has proved negative for it: a State, in which one has durably installed a great deficit of historical knowledge so as to manage it, can no longer be governed strategically."31 The spectacle appears to function with machine-like regularity and conspiratorial efficacy. Its actual invulnerability at any particular point of articulation or operation is, however, more an empirical and practical than an abstract theoretical question.

To Debord's analysis of the society of the spectacle, Agamben adds his own radical political analysis, which centers on the structure of sovereignty and the state of exception, as well as on his reflections on the negativity inherent in linguistic being. Something the society of the spectacle presupposes, but which needs to be understood alongside Debord's analysis, is what Agamben in his political works identifies as the "state of exception." Echoing Walter Benjamin, Agamben agrees that "today, the state of exception has become the rule." For insight, he has turned to the thinking of Carl Schmitt, political theorist of the National Socialist party, whose "decisionist" political theory provided the theoretical justification for the Nazi takeover of the German state through the implementation of a state of exception which lasted for the duration of the Nazi regime. Agamben's analysis here underlies his depiction of the camp as the nomos of the modern" the more or less permanent localization of this state of exception, as a concomitant to the stabilization of a sovereignty abstractly located in "the people," concretely exercised by "the State" and its permanent police force, and exercised over that "bare life" that is, through whatever mechanism, shorn of the contingent identifications that offer it only spectacular protection.

31. Debord, Comments, VII. 
This dystopian political and social situation rests on the negative foundation of western ontology. According to Agamben, that negativity is established philosophically in every component of western tradition: the dialectical (represented by Hegel), the phenomenological (represented by Heidegger), and the aestheticist (represented by stil novo poetics). In the analysis of the link between the voice, the subject, and the subject's identification as the "taking place of language in the Voice," this negative foundation shows itself for the emptiness it is. Agamben's delineation of this insight constitutes the substance of his text Language and Death. The challenge Agamben sees as before contemporary humanity is to interpret this ineluctable negativity in a way that overcomes its nihilism and lethality.

\section{Agamben's Theoretical Project}

Agamben's work as a whole builds on and advances this critique of contemporary culture, ethics and politics. His vision entails a sweeping condemnation of contemporary life, and implies that the core institutions of western society need to be re-imagined from the foundations up. Nevertheless, Agamben's work does not exude an atmosphere of pessimism. The recurrent note of determined hope is supplied by a principle expressed by Hölderlin, that "near the danger grows the saving cure." When the situation is most dire, the seeds of its own dynamic reversal may already be germinating, although the seedlings may be visible only to a keen analytic eye. ${ }^{32}$ So, for instance, Agamben writes almost optimistically in "Marginal Notes on Commentaries on the Society of the Spectacle" that despite the spectacle's destructive violence it "still contains something like a positive

32. Hölderlin's line occurs near the beginning of "Patmos," and recurs in Agamben's work. For a discussion of its use by Heidegger, Arendt, Horkheimer and Adorno, particularly in the context of aesthetics, see Durantaye, Giorgio Agamben, 40-43. Its universal validity seems questionable at best. 
possibility - and it is our task to use this possibility against it." ${ }^{33}$ Similarly, in Infancy and History, he writes that the "destruction of experience" that besets the people of the present day is less to be deplored than to be noted because "perhaps at the heart of this apparently senseless denial there lurks a grain of wisdom, in which we can glimpse the germinating seed of future experience." 34 What needs to be done is to discern these germinating seeds and nurture them.

Agamben's work is profoundly interdisciplinary. His earliest writing involves a meditation on aesthetics, and the role of the work of art in contemporary consciousness. He examines the structure of subjectivity as expressed in diverse structural relations, including those of poetry and philosophy, psychology, and linguistics, as well as through treatments of spatiality and image, in Stanzas. Throughout his work he has addressed issues of language, psychology, and most recently devoted extended reflections to politics and ethics. His interdisciplinary practice is tied to his insight that events in western political life have radically altered the conditions under which traditional disciplinary boundaries were established. Understanding the phenomena of interest demands thinking across traditional disciplinary lines. ${ }^{35}$

The diversity of these concerns is tied together by the guiding thematic thread of potentiality. Durantaye has identified profoundly interventionist motives behind this concern, linking them to reflections on political power and happiness. ${ }^{36}$ Agamben himself has said

33. Giorgio Agamben, Means Without End, 83.

34. Giorgio Agamben, Infancy and History, trans. Liz Heron (London: Verso, 2007) 17 .

35. Giorgio Agamben, "Absolute Immanence," in Potentialities, ed. and trans. Daniel Heller-Roazen (Stanford: Stanford University Press, 1999) 220-239, 239.

36. Durantaye, Giorgio Agamben, 15-17. Interestingly, Durantaye notes here the resonance of Agamben's interest in potentiality with remarks made by Adorno, and their common view that the philosophical vocation has to do with 
that his work constitutes a meditation on the statement "I speak," or alternatively, "I can."37 Another characterization of this project would be to say that Agamben's work focuses on the structure of modern subjectivity, and on an effort to move beyond the nihilism that the philosophical roots of modernism have uncovered. Agamben is a thinker who regards the grand tradition of western philosophy as having provided a fundamentally or radically dangerous conceptual basis for collective political life. His project concerns itself with the roots of western political institutions and western understandings of knowledge and the self. It always implies and sometimes states explicitly that these foundations or roots are the deep wellsprings of contemporary nihilism. Overcoming that nihilism, or turning it in the direction of happiness, calls for locating and rethinking those sources.

That rethinking draws on the work and insights of others. Most famously, Agamben draws heavily on Heidegger, an early and profound influence, and on Walter Benjamin. He has stated that Benjamin has acted as an "antidote" to the influence of Heidegger. ${ }^{38}$ At points, it seems clear that Agamben's own work constitutes an effort to articulate Heidegger's insights with those of Benjamin. ${ }^{39}$

Both Heidegger and Benjamin make language a central focus for philosophy. Not surprisingly, language appears as a privileged location for the observation and analysis of fundamental issues for Agamben as well. And while Agamben does not explicitly engage with Lacan, he does link the analysis of language and law throughout his work, beginning

intervention in a system that makes change for the better appear radically impossible.

37. Durantaye, Giorgio Agamben, 73-76, 129.

38. Ibid., 53.

39. The text of The Open presents the clearest example. In that text, chapters devoted to Heidegger's treatment of the difference between human and animal consciousness are followed by a chapter on Benjamin that acts as the antithesis to Heidegger's position, followed by a concluding chapter that serves less as the Hegelian synthesis than as a snapshot of the newly attained immanence. 
with his treatment of melancholy, fetishism, poetics and semiology in Stanzas. His diagnosis of the dilemma faced by contemporary culture returns again and again to the relation of subjectivity to the matter of language, and with the relationship of having language or being-inlanguage to human potentialities. Implicit in these relations are other, linguistically mediated, relations of sacrality and profanity, of identity and community, and of vocation.

Agamben's Interest in Language

Language matters profoundly because of the way it constitutes, or seems to constitute, subjects, their subjectivity, and the world. The Western metaphysical tradition has set language at the root of humanity itself, identifying the anthropos as the zoon logon echon. One facet of Agamben's project has been to uncover the complexities this identification introduces into humanity's understanding of itself. These complexities arise because of the way language itself constitutes an articulation of different things: language (Iangue) and speech (parole), words and discourse. ${ }^{40}$ This way of thinking makes human beings the site or place of the articulation between language as a field of potential and its discrete appearances in speech, its utterances or events. Human beings themselves become, in effect, the apostrophe or empty space of this articulation.

Another facet of the project, however, has to do with an uncovering of the dualities that run through and contribute to language. So, language reveals itself over and over to have a material side, to consist in something. ${ }^{41}$ Language involves a legion of inner articulations, including those of the semantic and semiotic series that form rhyme. Poetry brings these inner Iinguistic articulations to light,

40. Agamben, Infancy and History, 59.

41. Agamben, Idea of Prose, 37. 
while prose allows it to remain implicit in use, hidden in plain sight. The making of articulations themselves is an integral part of the western metaphysical project, which fascinates Agamben. ${ }^{42}$

One point Agamben emphasizes, in the text Language and Death and thereafter, is the way entry into language as a speaking subject effects a radical occlusion of the singular matter of the speaker. This occlusion of the singular stems from the entirely general and timeless character of the system of personal pronouns. This limited set of words, which seem so full of singular content, suffice for the communication of infinitely varied singularity because of their status as "shifters."43 They function, in fact, as indicators of an event of language, something which has a perfectly general and universal, strictly impersonal, aspect. Right at this point, language epitomizes something that Agamben finds fascinating: the coexistence of unique and general, singular and universal aspects in the construction of human linguistic subjectivity. The site of the construction of subjectivity through the use of language appears, in Agamben's analysis, as always already also a site of the potential awareness of something radically excluded from language in the act of its use.

Agamben, then, traces the western perception of the human subject's profound emptiness or negativity back to the origins of that subjectivity in the use of language, and of the way those origins have been appropriated philosophically. He has traced this core insight across diverse areas of application. In $\underline{\text { Stanzas }}$ he emphasizes the way this structure of subjectivity emerges in and contributes to the insights of medieval theology and religious practice, psychology, in literature, and linguistics. In Language and Death he investigates the

42. Agamben, ibid., 39-41; Time That Remains, 87; Stanzas, 152-157. 43. Giorgio Agamben, Language and Death, 19-26. 
way the metaphysics of language treats but fails to go beyond the negative foundation of the linguistic subject, and contrasts it with the use made of that negativity in early renaissance love poetry. In The Open he examines the role of these linguistic metaphysics in the operation of the "anthropological machine" that grounds an essential understanding of Being on a negative articulation of human and animal. Homo Sacer, especially the "ethics of witness" presented in Remnants of Auschwitz, extends this core insight to politics and ethics. Identity and Community

One significant consequence of this involvement of language in subjectivity is that the essentially linguistic elements from which people form identities can become traps. This is particularly true in a historical period when the proximate matter of these elements, that renders them communications of something, has ceased to hold, and terms of identification are used spectacularly as nothing but pretexts. Yet. another facet of Agamben's work sets out from this recognition towards the destination of an understanding of community that cannot be appropriated in this way by totalitarian efforts, because it does not ground itself in identifications of this kind. The fruit of this effort appears in The Coming Community, to be considered below. ${ }^{44}$

Another side of Agamben's critique of linguistic reification, however, appears in his critical appraisal of the institutions of contemporary political life. Homo Sacer is one case in point, where an essential element of Agamben's critique of the state form is its institutionalization of a structure of sovereign decision that is, at bottom, a consequential decision about what something is to be called or named. Aristotle's fundamental discussion of the polis, in contrast to the oikos and the marketplace, distinguishes between natural life

44. Durantaye, Giorgio Agamben, 156-161. 
(zēn) and that life that is to be called "good" (eu zēn), a distinction Agamben refers to most often as the distinction between bios, a particular form of life, and zoe, common life. ${ }^{45}$ The possibility for something like a biopolitical "bare life" to arise as a political problem owes almost everything to this original calling. Similarly, the sovereign decision on the "state of exception" that constitutes the power of the state on Agamben's analysis also rests in a constitutive power to name, and to make that naming a justification for action. ${ }^{46}$ Contemporary politics has become a site in which specified ways of being-in-language are attached to concrete practices with life or death consequences.

Yet another approach to the question of identity and identification has to do with the assumption of individual subjectivity. Agamben's work deals, at every point indirectly, with the crisis of an understanding of what the classical humanities thematize as individuality or personal identity. This problem sometimes appears as the question of "whatever being" or singularity, sometimes as the question of the articulation of the exemplary and unique with the shared or impersonal, as genius or special being, sometimes as the problem of expression and belonging in the creation of and relationship to the work of art. ${ }^{47}$ Ultimately, it is the problem of "face," that place in which human beings try to "seize hold of their own appearance and of their own being-manifest."48

45. James Gordon Finlayson, "'Bare Life' and Politics in Agamben's Reading of Aristotle," The Review of Politics 72 (2010) 97-126, argues that Agamben frankly misreads Aristotle, and Greek literature of the period generally, in alleging this distinction. Finlayson's critique, while cogent, underplays the more significant distinction Agamben rightly reads in Aristotle between mere zoe and that life which may qualify as "good," which he designates by bios.

46. See Agamben, Homo Sacer.

47. See Agamben, The Coming Community; Profanations, trans. Jeff Fort (New York: Zone Books, 2007) 9-18, 55-60; The Man Without Content.

48. Agamben, Means Without End, 91. 
Vocation, Inoperativity, and Profanation

Agamben's conclusions throughout his work return to the problem, and promise, for humans of their constitutive lack of a fixed nature that would impose a vocation or a specific telos on human activity and organization. Aristotle raises the question of whether man alone of all the animals has no proper work. Agamben answers the question with a resounding "yes," and endeavors to draw out the implications of a way of being that is essentially without a proper work that forms the condition of its existence. ${ }^{49}$ That answer has particular relevance to the fundamentally utopian question about the "best form of life" for human beings, usually implicit if not explicit in reflections on ethics and politics. Answers to questions about the good life have traditionally been sought in answers to the question of what people are supposed to do; the good life appears as the life that permits people to do it, and in and through which they succeed in doing it. If, on the other hand, there is no specific human vocation - if no "voice" addresses Dasein at its source, if there is nothing in particular to which humanity is called - then a radical and consequential freedom presents itself as humanity's potential. Thinking the implications of this radical freedom as something other than terror is another way to characterize Agamben's theoretical project. ${ }^{50}$

For Agamben, these implications touch the source of human ethics. Being without a proper or fixed work is, in fact, "the only reason why something like ethics can exist," rather than a set of "tasks to be done" inscribed in human nature like a metaphysical laundry list. ${ }^{51}$ The human lack of a fixed vocation is also what constitutes the ground of politics, "that which corresponds.. . to the radical being-without-

49. Durantaye, Giorgio Agamben, 6-7.

50. See in particular Agamben, Language and Death, 106.

51. Agamben, Coming Community, 43. 
work of human communities."52 One of Agamben's tasks as a theorist has been to foster a due regard for this human lack of work, in opposition to moralistic efforts to turn this radical "inoperativeness" in a repressive direction, and to the efforts of the integrated spectacle to turn it in a biopolitical direction. ${ }^{53}$ Durantaye points out Agamben's development of this modal view of inoperativeness out of the term's origins in radical political theory. This gives the notion of inoperativeness in Agamben a specific double meaning. Agamben can understand humanity to be capable of a radical political practice that would render inoperative the reified linguistic distinctions by means of which potentiality is twisted to the exercise of power, because of its own constitutive inoperativity. ${ }^{54}$

The emphasis Agamben places on "the profane" and "profanation" relates intrinsically to this notion of inoperativeness. He develops his thoughts on the political value of profanation most fully in the essay "In Praise of Profanation," where he cites the core meaning of "to profane" as being a return to free use of things that had been consecrated and separated for specifically religious use. For Agamben, separation and restriction on use "contains or preserves within itself a genuinely religious core," and the separations and restrictions on use accomplished by property under capitalism and by spectacular society within the integrated spectacle are no exception to this reading. ${ }^{55}$ What has been lost is neither the religious core, nor the sacrificial system that effects consecration and removal to a separate sphere, but the rites and practices, including play, that restore the balance of sacrifice and return what has been separated back to free

52. Agamben, Means Without End, 141.

53. Ibid.; Agamben, Coming Community, 44 .

54. Durantaye, Giorgio Agamben, 18-20; Agamben, Idea of Prose, 71.

55. Agamben, Profanations, 74 . 
use. This form of secular religion eschews redemption, produces guilt, and "does not aim at the transformation of the world but at its destruction."56 What is given in spectacular society is an effort to make everything without distinction unprofanable, in the face of which "the profanation of the unprofanable is the political task of the coming generation."57

How Agamben's readers are to understand his call to radical politicized profanation, particularly in light of the specific examples of profanation he advances, has given rise to searching questions. ${ }^{58}$ Agamben's portrayal of the contemporary world is one of exigency in the face of disaster. The integrated-spectacular world order in which people increasingly and exclusively live

- actually runs the risk of being the worst tyranny that ever materialized in the history of humanity, against which resistance and dissent will be practically more and more difficult - all the more so in that it is increasingly clear that such an organization will have the task of managing the survival of humanity in an uninhabitable world. ${ }^{59}$

The idea of an alternative to what Adorno termed "the unspeakable world that is," hovers around Agamben's works, despite the limited use Agamben's texts make of the term that has traditionally designated that idea: utopia. In its place, Agamben's rhetoric bends insistently towards urging his readers to end or put a stop to what he sees as the emblems of the dystopian situation of the global present. In Remnants of Auschwitz, he refers to the specter of a soccer match recalled by a witness at Auschwitz, between members of the Sonderkommando and the SS. For Agamben, as for his informant Primo Levi, that emblem of normal life in a context of ongoing horror represents "the true horror of the camp" and also "the shame of those who did not know the camps" and yet

56. Ibid., 80 .

57. Ibid., 92.

58. Mills, Agamben, 128-129.

59. Agamben, Means Without End, 87. 
continue to participate in the spectacle of normalcy in the midst of universal guilt. "If we do not succeed in understanding that match, in stopping it, there will never be hope." In The Open, the urgent problem is the two versions of the "anthropological machine," both of which are "lethal and bloody" and of which it is a matter "of understanding how they work so that we might, eventually, be able to stop them." In state of Exception the task appears as "ceaselessly to try to interrupt the working of the machine that is leading the West toward global civil war." All these stoppages must take place in an opaque zone of indistinction between things thought to be distinct, like human and animal, law and life, matter and meaning. Agamben has also said that only a politics that begins from this confusion can interest him, and that its positive task is to learn "how to grasp the stars that fall from the never dreamt-of firmament of humanity." 60

\section{Utopia in Agamben's Work}

That task, which is the "task of communism," is an explicitly utopian one; it corresponds to the "utopia of a classless society." Agamben claims that a glimpse of that utopia appears in pornography, in the use made of caricatures of class markers. ${ }^{61}$ Agamben notes that in pornography various signs of class are displayed only to be, literally, stripped off and cast aside; in being discarded, they are rendered inoperative as barriers to intercourse, social and otherwise. ${ }^{62}$ Agamben offers a different angle of vision on the matter of the classless

60. Agamben, Remnants of Auschwitz, 26; The Open, 38; State of Exception, trans. Kevin Attell (Chicago: University of Chicago Press, 2003) 87; Means Without End, 139; Idea of Prose, 75.

61. Agamben, Idea of Prose, 73-75. Contemporary analysts of pornography would concur with Agamben that the genre incorporates class critique. See Laura Kipnis, Bound and Gagged: Pornography and the Politics of Fantasy in America (Durham, NC: Duke University Press, 1999); Constance Penley, "Crackers and Whackers: The White Trashing of Porn," in White Trash: Race and Class in America, eds. Matt Wray and annalee Newitz (New York: Routledge, 1997).

62. Agamben ignores here, however, the significance of the class signifiers as incitements to the central action of the pornographic narrative; this function seems, perversely, to establish their operativity. 
society in his essay "What Is a People?" ${ }^{63}$ There he begins from the insight that the word "people," which names "the constitutive political subject," also always indicates "the class that is excluded - de facto, if not de jure - from politics," namely the poor. ${ }^{64} \mathrm{He}$ discerns in the term "people" another sign of the "fundamental biopolitical fracture" he has made it his task to expose. Something that purports to be a whole, in this case "the People," actually includes only the exclusion of a key portion of that whole. Integrity demands that "the People" rid itself of some "people" (e.g., non-nationals, speakers of other languages), while honesty demands that "the People" lose its integrity by including "the people" it aims to do away with. The class struggle, which it is the utopian goal of communism to bring to an end, Agamben claims - . is nothing other than this internecine war that divides
every people and that shall come to an end only when People
[the political subject] and people [the excluded] coincide, in
the classless society or in the messianic kingdom, and only
when there shall no longer be, properly speaking, any people. ${ }^{65}$ Agamben takes seriously what he reports as Walter Benjamin's "thesis, that the Marxian concept of a 'classless society' is a secularization of the idea of messianic time." ${ }^{66}$ For Agamben, talk about "the messianic" amounts to talk about utopia.

Agamben does, however, make a limited number of explicit references to utopia outside the context of "messianic" motifs. Those references have in common an obscure form of spatiality. He introduces his reflections in Stanzas as a "topological exploration . . constantly oriented in the light of utopia," on the understanding that "only if one is capable of entering into relation with unreality and with the

63. Agamben, "What Is a People?" in Means Without End, 29-35.

64. Ibid., 29.

65. Ibid., 32-33.

66. Agamben, Time That Remains, 30 . 
unappropriable as such is it possible to appropriate the real and the positive."67 In an essay on Guy Debord's "Commentaries on the Society of the Spectacle," he notes that the Situationists' "utopia is, once again, perfectly topical because it locates itself in the taking-place of what it wants to overthrow." ${ }^{68}$ Similarly, in The Coming Community, "The taking place of things does not take place in the world. Utopia is the very topia of things." 69

In each of these cases, Agamben's comments are explicitly spatial. The space to which they refer is the phantasmatic, poetic space he identifies in The Man Without Content as the space of art. Agamben concludes that work with the observation that art in late modernity is required to confront the problem of humanity's inability to appropriate its own historical time and place by means of a seamless cultural transmission that locates it in an intelligible world. Art accomplishes this task by renouncing its "guarantees of truth," namely its traditional relationship to culture, to permit it to create a phantasmatic space independent of culture in which humanity might continue to seek to know its own meaning through reflection on its culture. ${ }^{70}$ Art does not necessarily succeed in this task; indeed, in the contemporary world it seems doomed to fail. More important for this study, however, is the way Agamben locates in art an exemplar of a kind of knowledge that dwells in the creation of an outside out of materials found exclusively within the world.

This section aims to make clear how this perplexing treatment of utopia features in Agamben's overall work by looking more closely at the works in which he treats utopian themes at greatest length. A

67. Agamben, Stanzas, xix.

68. Agamben, Means Without End, 79.

69. Agamben, Coming Community, 102.

70. Agamben, Man Without Content, 114. 
closer look at The Coming Community, The Open and The Time That Remains will demonstrate that Agamben's utopianism incorporates an attack on the idea of utopia as a represented future. It is instead a call to risk a specific form of non-knowledge that takes place in proximity rather than identity. The index of this thought's utopianism is its connection to happiness, and its negative relation to pain, the core methodology of power. ${ }^{71}$

\section{The Coming Community of Whatever Being}

Antonio Negri reads The Coming Community as a jolt in which "the experience of redemption presents itself as distopia."72 This jolt comes early, in Agamben's use of the experience of the souls in limbo as a figure for simple happiness. He presents the perdition of the nondamned as a divine abandon without pain, a "neutrality with respect to salvation" that constitutes "the most radical objection that has ever been levied against the very idea of redemption." 73 Whether or not Negri, who favors an orientation toward redemption, should persuade Agamben's other readers depends on the assessment of the "whatever being" that is the material of the community that is coming. While Agamben presents it as "lovable," happy, free and "simply human life," its content is in many ways uninspiring. ${ }^{74}$ Its "exemplars" are "[t]ricksters or fakes, assistants or 'toons," and one way to think of it might be to think of "the planetary petty bourgeoisie" minus "bad mediatized advertising."75

71. According to Agamben, potentiality is the deferral of pleasure, or pain. "Power grounds itself" on the various forces which constrain potentiality to pause, and to delay its ultimate satisfaction. "Power bases its authority on this upgathering of pain. It literally leaves the pleasure of man unfulfilled." Agamben, Idea of Prose, 71 .

72. Antonio Negri, "The Ripe Fruit of Redemption," http://www.generationonline.org/t/negriagamben.htm, May 23, 2010, 1.

73. Agamben, Coming Community, 6.

74. Ibid., 2, 7 .

75. Tbid., 11, 65 . 
This coming community that emerges from Agamben's presentation seems to lack many of the features typically associated with political utopias. His descriptions are evocative, abstract and figurative rather than precise or polemical; they do not include pragmatic solutions to familiar political problems, like class conflict or ecological degradation. The community of whatever being Agamben described does respond, however, to one pressing historical and political problem. The totalitarian phenomena of the late $20^{\text {th }}$ century demonstrated the vulnerability of various forms of collective identification - not only nationalism or traditional nativism, but progressive or revolutionary identifications like socialism or communism - to capture and cooptation by the state. A community with no criteria for totalitarian exclusion, however, would be an almost unimaginable community with no criteria for inclusion, either. Agamben's work in The Coming Community is an effort to develop the philosophical basis for such community that would be invulnerable to such cooptation. ${ }^{76}$

Agamben accomplishes this task by developing the basis for a community of what he calls "whatever being." This being defines a form of singularity, and of these singularities' co-belonging, that accommodates all potential manners or ways of being while avoiding determination by any of these. He presents a series of examples that develop the notion of this mode of being: the example, a form of purely linguistic being which illustrates a general case in a way that is entirely specific, and which creates an empty space for communication; a line of handwriting, in which all the characteristics that make the general letters part of someone's handwriting in particular cannot be filtered and separated from the writing to yield a general writing without any specific characteristics; the halo, which is the

76. Durantaye, Giorgio Agamben, 156-161. 
inessential addition to perfection which permits the individuation of the entirely general blessedness of paradise. ${ }^{77}$

Whatever being is not immune to evil. Agamben addresses the problem of evil in this context only briefly. For the coming community, "truth is revealed only by giving space or giving a place to non-truth - that is, as a taking-place of the false, as an exposure of its own innermost impropriety."78 "Evil . . . is the reduction of the taking-place of things to a fact like others, the forgetting of the transcendence inherent in the very taking-place of things."79 In Agamben's scheme, evil appears as a metaphysical attitude that denies the routine and awe-inspiring character of the facticity of the world, its contents, and its inhabitants. It is also a specific inadequacy in facing the exposure to death, the "power of not-being" that constitutes a "demonic element" in every being. "Evil is . . our fearful retreat from it in order to exercise - founding ourselves in this flight - some power of being." ${ }^{80}$ Evil, in other words, from a different perspective, is that response to the problem of the death-drives that violently suppresses the awareness and accommodation of the power to not-be in itself by projecting it onto another singularity and violently asserting the power to be against it. Evil amounts to a refusal to rely on the power to not not-be, the anxious refusal to let-be the power to not-be in every thing.

The persistence of this "demonic" temptation exposes the coming community at every moment to evil. Thus, in spite of its often delightful descriptions, it does not constitute a utopia in the ordinary sense. It has not vanquished the possibility of suffering. In

77. Agamben, Coming Community, 10, 20, 54-56.

78. Ibid., 13 .

79. Ibid., 15.

80. Ibid., 32 . 
fact, under current conditions, it is decisively exposed to violence. Agamben paints the coming community in the colors of happiness and blessedness, drawing from an unusual range of sources: the novels and stories of Robert Walser, the discussions of Thomas Aquinas and the Talmud, medieval images of heaven, rabbinical and cabbalistic stories of the world to come, and hosiery advertising. What these diverse images share is a sense of simplicity, an unassuming joy in facticity, and an innocent impropriety. The coming community emerges in the guise of a delightful, happy place, full of slightly misshapen but utterly ravishing singularities. But these singularities are perfectly "exposed" in their "exteriority." They really have nothing that might be called inner resources, and they have no shelter in a more powerful, overarching identity. Agamben explicitly points out the vulnerability of this community without identity or presuppositions to state violence: "Wherever these singularities peacefully demonstrate their being in common there will be a Tiananmen, and, sooner or later, the tanks will appear. "81

"The very topia of things"

This vulnerability to violence and suffering at the hands of an entity that is based on presuppositions or identities suggests that the coming community is not an ordinary utopian community. It is, however, a community of being with utopian possibility. Moreover, this utopian possibility is embedded in its constitution as whatever being, because "Whatever. . . is the event of an outside" and incorporates as its constitutive possibility "the absolutely non-thing experience of a pure exteriority," a "being-within an outside." ${ }^{82}$ The passage to an outside that takes place in the encounter with whatever being, which Agamben

81. Ibid., 87.

82. Ibid., 67,68 . 
terms its "face," is fundamentally a grounded experience of

potentiality in relation to things "as such."

Agamben develops an argument to support this understanding of

whatever being in an appendix to the main text of The Coming Community,

titled "the Irreparable." That appendix is presented explicitly as text

that "can be read as a commentary on section 9 of Martin Heidegger's

Being and Time and proposition 6.44 of Ludwig Wittgenstein's Tractatus"

and which, as such, deals with the question of "the relationship

between essence and existence."83 Agamben's commentary has been read as

being in fundamental accord with Heidegger's and Wittgenstein's

treatment of this question of metaphysics. ${ }^{84}$ This reading, however, does

not do full justice to the actually utopian import of Agamben's

thinking on this point. It would be helpful, in fact, to read it also

as a commentary on Adorno's concluding comment in Negative Dialectics,

"Represented in the inmost cell of thought is that which is unlike

thought. " 85

Agamben concludes his brief, dense argument with the statement "How the world is - this is outside the world."86 For an ontological

reasoning that denies the possibility of an outside vis-à-vis the world, this statement simply states the impossibility of a perception of "how the world is." However, Agamben has explicitly stated that this perception is possible, and takes the form of seeing something as "irreparable" and "in its being-thus." 87 This amounts to a perception of its simultaneously non-necessary and non-contingent existence from the perspective of a non-thing experience of exteriority, i.e., from the

83. Agamben, The Coming Community, 89. Section 6.44 of wittgenstein reads "It is not how things are in the world that is mystical, but that it exists." 84. Durantaye, Giorgio Agamben, 198.

85. Adorno, Negative Dialectics, 408.

86. Agamben, Coming Community, 106.

87. Ibid. 
perspective of "whatever being." This being explicitly has the capacity to lose itself in things "to the point of not being able to conceive of anything but things" and then "in the experience of the irremediable thingness of the world" to experience the event of an outside. Again explicitly, "The taking-place of things does not take place in the world. Utopia is the very topia of things." ${ }^{88}$

In other words, the very human potential to notice that it perceives things as such, as things, constitutes the opening up of a limit, and effects the taking-place of a passage outside the world. This odd and yet also familiar experience of thinking and speaking that catches itself in the act, constitutes the transformation of the aporia of the irreparably factitious character of the world into the "euporia" of the "threshold" that makes evident its relationship with an outside. Whatever being, which only ever emerges as whatever singularity, is the site of the taking place of that experiential event. That is, whatever being, whatever singularity, is the potential experience of the utopia that is the very topia of things.

Recognizing whatever being as the site of this experience of an outside makes sense of Agamben's paradoxical statement about "redemption" as the "advent of a limit" in the recognition of irreparability. ${ }^{89}$ That statement bears quoting at length.

We can have hope only in what is without remedy. That things are thus and thus - this is still in the world. But that this is irreparable, that this thus is without remedy, that we can contemplate it as such - this is the only passage outside the world. (The innermost character of salvation is that we are saved only at the point when we no longer want to be. At this point, there is salvation - but not for us.) ${ }^{90}$

Initially, the idea of hope in what is without remedy appears paradoxical. The paradox is resolvable insofar as hope, which depends

88. Ibid., 103.

89. Tbid., 101.

90. Ibid., 102 . 
upon the possibility of a position that defeats the twin poles of necessity and contingency, is possible. This position is available, but only in the encounter with what is "without remedy," that is, in the encounter with what is irremediable, irreparable. Hope is only possible in the encounter with that which simply is in its character as "that which it is," its character as "the thus." This character is explicitly not its character as the bearer of thus or thus identifiable property, but its character as whatever being, its character as being nothing other than "the thus," the irreparable. ${ }^{91}$

The innermost character of "salvation," then, entails an encounter with "the thus" that does not give rise to a desire for salvation. If "we" are saved at the moment when we no longer want to be, it is presumably less because "we," whoever we are, have achieved some remarkable form of transcendence, than it is because "we" are no longer faced with the kind of challenge that makes us wish we were someone else, somewhere else, facing something else. But if "we" are longing for some kind of salvation, "we" definitively are not participants in whatever being it is that no longer wants to be saved. "We," however, for whom there is not salvation, might be in a position to interact with the things taking place around us in ways that contribute to a happier experience, whether in the world or outside it, at some other point, for some other "we."

Agamben's utopia, the not-in-the-world that is the very taking place of things as things, whatever they are, involves a definite linguistic relationship, which Agamben describes as "the being-inlanguage-of-the-non-linguistic." ${ }^{92}$ Grasping this relationship is an effort to counter Wittgenstein, and also Heidegger, in a move that will

91. Ibid., 103.

92. Ibid., 95 . 
bring the "unutterable" to expression, and recognize that the "thing of thought is not the identity but the thing itself' or, in other words, a thing that "transcends toward itself, toward its own being such as it is. ${ }^{93}$

Agamben describes transcendence toward itself further, as an element of linguistic signification that differs both from meaning and from denotation, an element he claims is the inner meaning of the Platonic theory of ideas. In what he calls "a Gnostic reading of the Platonic idea," he presents the idea as the "being-such" of each thing which is this aspect of linguistic being. This "being-such" amounts to an exposure or knowability of the thing's features, not as predicates but as "a limit. . . a halo;" being-such is in effect a mode of being that hovers in the gap between linguistic and non-linguistic being. ${ }^{94}$ This mode of being becomes apparent as an event of relationship; it takes place as a consequence of the difficult to think being-inlanguage-of-the-non-linguistic. That constitutes a relationship of language and something non-linguistic as a relationship of some nonthing exteriority that gives itself to knowing what is knowable as something knowable with something that gives itself to knowing as something which can be known as something knowable.

Agamben's line of reasoning in The Coming Community is not at all a simple embrace of an immanence of being in existence. Instead, it is a recovery of a form of transcendence, albeit a strictly limited form. Transcendence does not present itself as an alternative world lying beyond the world of things into which someone might be able to step, as into a fully formed utopia. Transcendence presents itself instead as a utopia that transforms the aspect of the existing world into that of

93. Ibid., 95. See Adorno, Negative Dialectics, 9 and 408 .

94. Ibid., 101. 
one way or manner of being alongside other potential, imaginable ways. None of these potential ways escape the irreparable facticity of the world of things. This awareness of irreparability, however, exposes the potential of that irreparability. That aspect of the world, therefore, constitutes a threshold before which the profane things of the world present themselves as available for creative use. The re-formed or trans-formed world that takes shape in that creative use would still be irreparably thus, but its difference from some other manner of beingthus might not be a matter of indifference.

\section{Anthropological Machine Out of Order}

A profanely re-formed or trans-formed world would presumably be the site for the coming community. Agamben develops another approach to understanding the nature of that re-formed or trans-formed world in The Open. The text of The Open is a reflection on treatments of the relationship of human to animal, a classic philosophical theme. These reflections are contained within an inclusio that focuses on a miniature in a Hebrew Bible in the Ambrosian Library in Milan. Agamben begins The Open with a description of that miniature, and returns to the image at the conclusion of the text.

The image in question depicts "the messianic banquet of the righteous on the last day." In that tiny and telling depiction, "the miniaturist has represented the righteous not with human faces, but with unmistakably animal heads." ${ }^{95}$ Agamben at first suggests that the picture may point towards a new form of articulation between animal and $\operatorname{man}[$ sic], a reconciliation. Such a reconciliation would, as we have seen, parallel one of the traditional themes of utopian discourse in the western tradition, in which the estrangement between humanity and nature, including humanity's own animal nature, has been identified as

95. Agamben, The Open, 2 . 
a source of suffering. He concludes with a reading of the illustration that sees in it a happy renunciation of the effort of articulation and reconciliation. That renunciation would signal the "Shabbat of both animal and man," allowing the image to present a "figure of the "great ignorance' which lets both of them be outside of being, saved precisely in their being unsavable."96

Agamben's theme of unsavability echoes the irreparability announced in The Coming Community. In that work it is the signature of a mode of being that provides a foundation for a viable community. Its re-emergence at the conclusion of The Open, in relation to the utopian project of the reconciliation of human and animal natures, reinforces its role as a utopian motif in Agamben's work. Its relationship to the dominant critical moment in The Open further demonstrates the changed understanding of the subject whose task it could be to "contemplate a human nature rendered perfectly inoperative" because of the suspension of the effort to maintain the always articulated, and always separated, concepts of human and animal. ${ }^{97}$

Between the two arms of this inclusio, the heart of The Open is Agamben's development of a critique of the way the notion of "the human" has been understood. This paradigm, moreover, relates intimately to the understandings available within the western tradition for imagining the completion or consummation of human life. In Agamben's view, the complex western imagination of the fulfillment of human nature, whether that is conceived as the "messianic end of history or the completion of the divine oikonomia of salvation" poses a critical limit problem concerning the difference between animal and human, which involves "a fundamental metaphysico-political operation in which alone

96. Ibid., 92.

97. Ibid., 87. 
something like 'man' can be decided upon and produced."98 What Agamben calls the "anthropological machine" that produces the recognition of the human in its differentiation from the non-human which it resembles also determines the parameters of the imagined fulfillment of the nonnature of humanity, whether in a theological or political ideal. ${ }^{99}$

Agamben traces the roots of this debate back to the earliest intellectual sources of the western tradition in Aristotle's De anima, considering its deployment in several exemplary moments, including Heidegger's treatment of profound boredom. "Man," he claims, "is always the place - and, at the same time, the result - of ceaseless divisions and caesurae."100 These divisions precede and implicate the articulations that have been thought to define humanity, such as the articulation of body and soul or the articulation of a natural with a social or spiritual element. This is no small matter, as the western humanistic tradition rests on some understanding of "the human," and a decision on one understanding in preference to another is decisive for the selfrepresentation of culture and the imagination of ideal life. In each case he examines, Agamben uncovers an effort to locate something to be identified as the proper domain of humanity by virtue of its contrast with something designated as animal. In each case, moreover, the effort fails. The negative definition of the human as the not-animal always already includes the animal within itself, in the form of an attempted exclusion; it always ends with a demonstration that what is claimed as most properly human fails to distinguish what is called human from what is called animal.

The relationship of the human to the animal therefore takes the form of what Agamben has identified elsewhere as a state of exception.

98. Ibid., 21.

99. Ibid., 29.

100. Ibid., 16. 
In political life, the bare life or zoe that Aristotle relegates to the oikos, the household, remains included in the form of an exclusion in the specific form of political life (the bios politikos) of the political community, or polis. This inclusive exclusion or exclusive inclusion is the point of entry in western politics for the lethal biopolitics of the contemporary state. In The Open, Agamben identifies the structurally analogous relationship between the animal's bare life and the human life in which it is included. The anthropological machine includes animal life within human life in the form of an exclusion; humanity is its negation, the denial of animality that produces the human's specificity in contrast. That relationship leaves this bare Iife exposed at the center of human life. The humanity that claimed at every point to be something essentially other than that merely bare life can sustain this demand only by taking upon itself an essential negativity or nullity. "Ontology . . is not an innocuous academic discipline, but in every sense the fundamental operation in which anthropogenesis, the becoming human of the living being, is realized."101 That realization underwrites the nihilism of contemporary culture: ". . because the world has been opened for man only by means of the suspension and capture of animal life, being is always already traversed by the nothing."102

Agamben sees a way past the alternatives donated by Heidegger's thinking on this matter, which pose a choice between the technological solution of biopolitics or the embrace of the abandonment of animal immanence. This way entails a recourse to "a sort of Benjamin ex machina."103 Agamben analyzes a collection of Benjamin's statements as proposing "an entirely different image of the relationship between man

101. Ibid., 79.

102. Ibid., 80.

103. Durantaye, Giorgio Agamben, 331. 
and nature and between nature and history" with which his investigation is concerned. ${ }^{104}$ While nature remains an area of "closedness" and "night," it is not thereby deprived of knowledge and even redemption. Nature for Benjamin appears as the "saved night," which maintains a relationship with something unsavable, completing it, and thereby disclosing itself as a "messianic nature" whose rhythm is happiness. ${ }^{105}$ Instead of humanity consisting in the mastery of an animality that excludes knowledge and cultivation, Benjamin suggests that what needs to be mastered is the very relationship itself between humanity and animality or nature. This mastered relationship does not require an articulation of "nature and man in order to produce the human through the suspension and capture of the inhuman," but rather seems to put the anthropological machine on hold, suspending both terms of the polarity. A different sort of being altogether, not yet named in language, takes up residence "in between nature and humanity."106 In Benjamin's account, "the woman" acts as a kind of maieutic eternal feminine, who does not so much draw the man ever higher, but "cuts" his mysterious bonds to his natural mothers and perhaps even life itself, permitting him to die and be reborn. ${ }^{107}$ Agamben's development of Benjamin's image takes the form of an exegesis of Titian's Nymph and Shepherd in the Kunsthistorisches Museum of Vienna. He reads the painting as an image of post-coital otium that provides a more intimate picture of something like whatever being as "the supreme and unsavable figure of Iife."108

104. Ibid., 81.

105. Ibid., 82. Agamben here cites Walter Benjamin, Letter to Florens Christian Rang, December 9, 1923, trans. Rodney Livingstone, in Walter Benjamin, Selected Writings, vol. 1, 1913-1926, ed. Marcus Bullock and Michael W. Jennings (Cambridge: Harvard University Press, Belknap Press, 1996), 389. 106. Ibid., 83.

107. Ibid., 84.

108. Ibid., 87. 
Agamben's vision of completed in-humanity here is bound to come as a disappointment to some of Agamben's readers. It raises legitimate suspicions with respect to his analysis, as well. This may have something to do with Durantaye's careful avoidance of this element of The Open. Catherine Mills notes that there is something old-fashioned about this image of completed life, standing as it does in a long tradition of "casting women as the privileged figures of ephemerality," unable to rise to the level of the universal themselves but able to give men the necessary boost, as well as women's "closer relation to the physiological or biological," all of which seem operate in this text. ${ }^{109} \mathrm{Mills}$ has less to say about the fundamentally romantic casting of "the woman" as the figure of specifically "messianic" nature in this fragment, in what is difficult not to read simply as yet another version of the eternal feminine.

It may be, however, that Agamben's thought is here operating at or near the limit of the representations available to it in the system with which we have to work. Agamben's - and Benjamin's - inadequate resort to the metaphor of heterosexual fulfillment may be an effort to aim for territory in the neighborhood of the place between-two staked out by Irigaray. Agamben's particular limitation here is a failure to treat explicitly the conflation of woman, animal, and nature that complicates the "simultaneous division and articulation of the animal and the human" of which "man has always been the result."110 That conflation, as others have amply demonstrated, is every bit as old as the one that forms the states of exception with which Agamben works; he could continue to cite Aristotle's Politics. The Iife he tries to imagine here, however, which will presumably require a suspension of

109. Mills, Philosophy of Giorgio Agamben, 115.

110. Agamben, The Open, 92. 
these metaphors as well, is in its own way an effort to read the surpassing of humanity's historical task as calling - as does Irigaray - for "an unprecedented inquiry into the practico-political mystery of separation." "111

Agamben on Messianic Time in The Time That Remains

Agamben's understanding of messianic or completed time is set out most completely in The Time That Remains, a detailed exegesis of the first verse of the Epistle to the Romans. According to Agamben, Paul recapitulates or sums up the entire contents of the much longer letter to the Roman church in the words of the incipit contained in Romans $1: 1$. "Understanding the incipit therefore entails an eventual understanding of the text as a whole."112 Agamben reads this verse, in opposition to most standard translations, as "Paul, called as a slave of Jesus the Messiah, separated as apostle for the announcement of God."113 The text of The Time That Remains is an exegesis of the meaning of each word and phrase of this identification of the author of the letter to follow. The letter to the Romans is significant, in Agamben's words, because it is central to the Pauline letters; these in turn constitute "the fundamental messianic text for the Western tradition."114 "This messianic message has been blunted across 2,000 years of Christian and Jewish exegesis of the Pauline corpus, for reasons having to do with the paradoxical position of "a messianic institution - or rather, a

111. Ibid.

112. Giorgio Agamben, The Time That Remains, trans. Patricia Dailey (Stanford: Stanford University Press, 2005) 6.

113. The Greek text, transliterated as PAULOS DOULOS CHRISTOU IESOU KLETOS APOSTOLOS APHORISMENOS EIS EUAGGELION THEOU, permits this reading. More familiar translations emphasize Paul's status as slave and the separation of the gospel rather than the apostle, and leave "Christ" untranslated, as in Karl Barth's "Paul, a servant of Jesus Christ, called to be an apostle, separated unto the gospel of God . . ." Ibid., 6; Karl Barth, The Epistle to the Romans, trans. Edwin C. Hoskyns (Oxford: Oxford UP, 1968) 27.

114. Ibid., 1. 


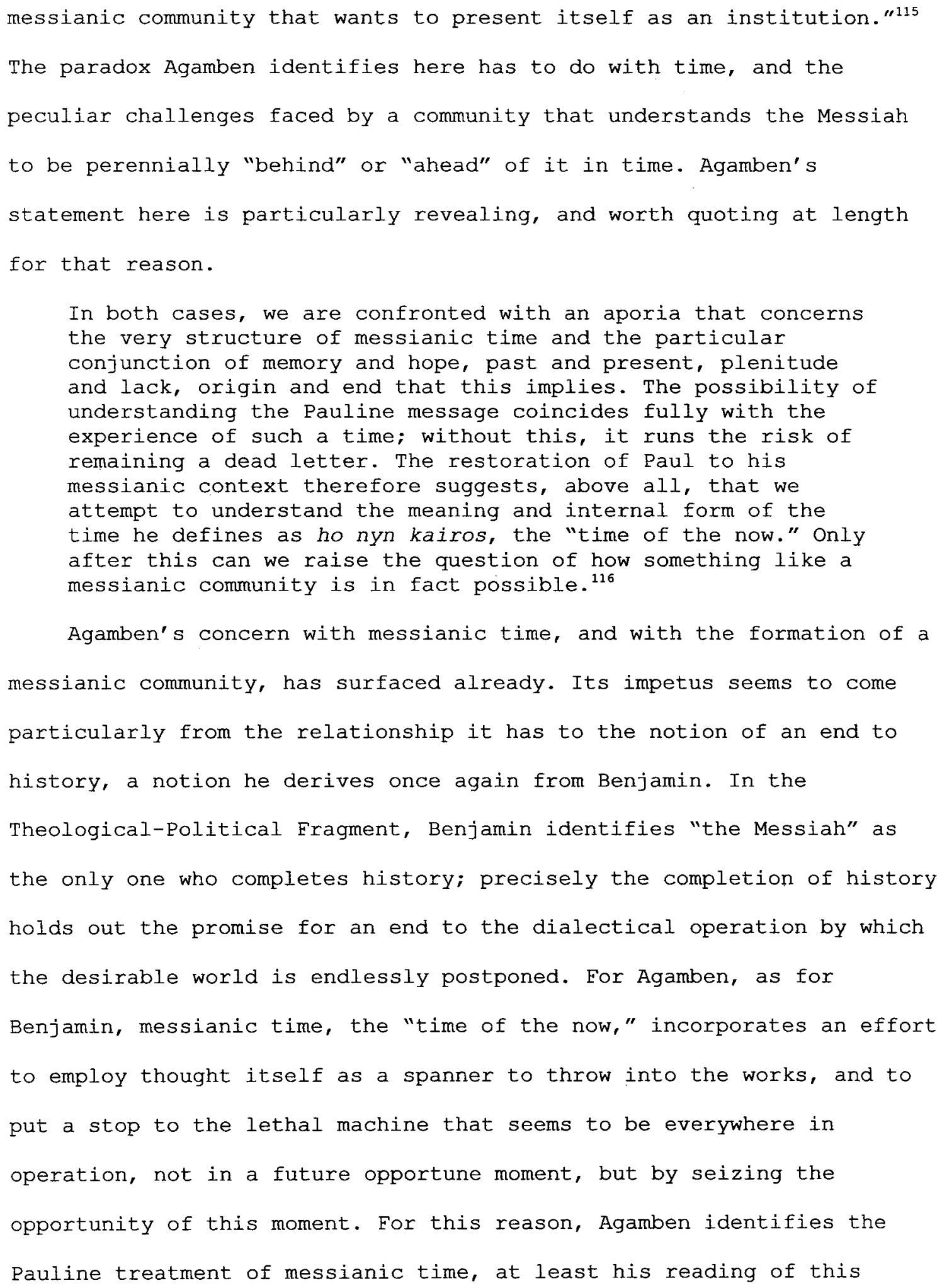

115. Ibid.

116. Ibid., 1-2. 
treatment, as being of central importance in facing the political challenges of the present.

The question Agamben seeks to address specifically is "What does it mean to live in the Messiah, and what is the messianic life? What is the structure of messianic time?"117 While presumably this is the question perennially before the Christian community to which Paul writes, it is also at this time, as becomes clear in the course of the seminar of which The Time That Remains is a record, a pre-eminently political question that is irrevocably before the global political community. This political question remains on the agenda despite, even perhaps because of, the "fall of communism," as Agamben reads Marxism as straightforwardly presenting a secularized form of messianism. ${ }^{118}$ The term klētos, klēsis, "called," "calling," interests Agamben. His analysis of the verb "to call" involves a glance at the theory of callings or Stände that was associated with the Pauline text. He investigates the textual history that induced Luther to translate klēsis with the German Beruf, and which then obtained a "new ethical meaning" among the Lutherans and Calvinists. Weber understood the term calling to convey an attitude of "eschatological indifference." Agamben, however, concludes that Paul is not talking about an attitude of eschatological indifference, nor of a command to steadfastly refuse to leave the calling in which one first hears of Christ. Instead, his use of this language "signifies the immobile anaphoric gesture of the messianic calling, its being essentially and foremost a calling of the calling."119 That is, in Agamben's analysis, Paul understands the messianic invocation as being one of calling all of the profane,

117. Ibid., 18 .

118. Ibid., 72 .

119. Ibid., 23. 
worldly callings, whatever their character, into an altered messianic use.

Agamben's discussion of the term aphörismenos is also detailed. Here, he finds that Paul has devised a way of thinking about division that cancels or nullifies existing divisions. The term aphōrismenos stems from the same conceptual field as the term Pharisee, the group set apart for special observance in $1^{\text {st }}$ century Palestine, the group that appear throughout the gospel accounts of Jesus' ministry. In following the meaning of this term, Agamben notes that 'the principle of the law is thus division."120 The people of the land are divided from the pharisees, as the Ioudaioi or Jews are divided from the ethnē or "people".121 Into this fundamental division of the law, between Jews and non-Jews, Agamben sees Paul drawing another dividing line that renders the initial division inoperative, null and void. By making further distinctions, e.g., "Jew according to the breath" vs. "Jew according to the flesh," he inserts a division into the pre-existing division, which creates a new, neutralizing category, that of non-non-Jew. This category exists beyond the existing divisions of identification, and offers the possibility of uniting people in a way that does not depend on any identification.

Here Agamben is explicitly setting his reading of Paul and Romans in opposition to that of Alain Badiou in Saint Paul: The Foundation of Universalism. ${ }^{122}$ Agamben is specifically reading Paul not as a founder of universalism, but as someone who destroyed universalism in favor of something more particular, a particular category that sidestepped identification, and in which dis-identified individuals could belong

120. Ibid., 47 .

121. Ibid.

122. Alain Badiou, Saint Paul: The Foundation of Universalism, trans. Ray Brassier (Stanford: Stanford University Press, 2003). 
apart from any shared identification. This is precisely the opposite of universalism, which unites by finding a transcendent shared identification or that bridges gaps between competing identities. Far from being a "producer of the Same," Paul is rather a producer of strategic and effective difference, the specific difference of a "remnant."123

For Agamben, the remnant makes it impossible for any part of a thing to correspond to any whole. It is relevant to notions of democracy and people. The "people," for Agamben, has the structure of a remnant, "that which can never coincide with itself, as all or as part, that which infinitely remains or resists in each division" and which "is the figure, or the substantiality assumed by a people in a decisive moment, and as such is the only real political subject." 124 It is the only real political subject because it is the subject that functions for the sake of a specific transformation in the decisive moment of its constitution. Agamben makes explicit note of the relationship of the Pauline remnant to the Marxian proletariat, noting that more than one analogy may be drawn. His sympathies seem to lie with an analysis of the "pleb" offered by Foucault, to the effect that while the pleb itself may not exist, something plebian characterizes many phenomena, and represents, with respect to power relationships, "their limit, their ruin, their consequence."125

For the understanding of Agamben's political subject, then, this Pauline understanding of the remnant is of first importance. Agamben's remnant is a subdivided group, a non-non-participant with respect to pre-defined identities, groups whose political interests and programs are already defined by social position and historical agendas. It has a

123. Agamben, Time That Remains, 53.

124. Ibid.

125. Ibid., 58. 
freedom of action provided by its non-coincidence with any of these pre-established groups, and by its own non-status as the "all" of some future, telic condition, which it may nevertheless also be free to envision.

Agamben labors to clear up a number of misconceptions with respect to this messianic time. First, it elucidates something about the relationship of kairos, or "occasion," to chronos, or chronological time, the time that passes in regular rhythm and whose passing can be measured by clocks and calendars. He notes that any kairos always has as its disposal chronos, in effect has no other time than chronos to provide it with substance, making it something graspable. Messianic kairos is, in the end, nothing other than "seized chronos," not some additional or other kind of time. ${ }^{126}$ Implicit in this analysis is that all chronos is potentially kairos. Kairos consists, ultimately, of ordinary time in the aspect of its having been seized in and for a use specific to an occasion.

Similarly, the parousia involved in Paul's discussion is not something supplemental that can be added on to the representation of time. The messianic community might be depicted as living its life in endless deferral, but such an endless deferral is not the Pauline picture, according to Agamben. Rather, the parousia already establishes a messianic time of the now. The time of the now lengthens out, not in order to endlessly defer its fulfillment, but so that its instantaneous present character can be grasped. Here Agamben has recourse to Kafka's comment that the Messiah will not come on the last day, but on the very last day. Agamben sees the same structure, of the stretching out of time, at work in Paul's texts. Pauline messianic time is still "the day," not the "very last day."

126. Ibid., 69. 
He focuses as well on the phrase "eis euaggelion theou." For Agamben, a matter of first importance is that in the letter to the Romans, the announcement of something is indistinguishable from the something that is being announced. "The letter is thus the impossibility of distinguishing between the announcement and its content."127 This indistinguishability is particularly significant for Agamben, whose interest in every question originates in its peculiar illumination of the problem of language. In the gospel - that is, in the announcement, the euaggelion, not in the literary genre of a narrative of the life of Jesus - at every point the text of the letter, the announcement of the message, and the good announced coincide. In elucidating this problem, Agamben finds himself drawn into the difficulties of Paul's critique of the law. ${ }^{128}$

Here again Agamben discerns an internal division peculiar to Paul's thought, and one that defines the nature of the messianic. Agamben's presentation of this internal division will take the reader all the way to what he describes as an experience of the pure event of language, which for Agamben will serve to reinsert a specific encounter with something other than language, something outside language, as an outside that counters the pervasive nihilism of the critical moment that makes for the legibility of the Pauline messianic text. How he arrives at this dénouement is significant, and hinges on a series of articulations of linguistic and judicial theory. The themes that are perennially important to Agamben, and that surface in all of his works appear here as well: inclusionary exclusions and exclusionary inclusions, divisions of divisions, the significance of poetry as an articulation of semantic and semiotic series, the relationship of Hegel

127. Ibid., 89.

128. Ibid., 92. 
to Heidegger, the fundamental role of potentiality, and the importance of making things inoperative.

According to Agamben, the Pauline treatment of the law figures prominently in the interpretation of the pure announcement that is inseparable from its content and the good signified in that content and announcement. This treatment does not simply oppose faith to law, as an opposition of two things external to one another, but delves into an area in which it becomes possible to understand that the law is fulfilled in its being made inoperative (in Greek, katargein). "Messianic katargēsis does not merely abolish; it preserves and brings to fulfillment."129 Significantly, he notes that Luther translates the Pauline verb katargein as aufheben, the verb associated with the key process of the Hegelian dialectic, that which preserves in going beyond or negating. He suggests that the characteristic double meaning of aufheben picked up by Hegel owes its origin to the double meaning of katergein encoded by Paul, and transmitted and bequeathed to German by Luther and his influential translation of the Biblical text into the vernacular.

Philosophically; "what is essentially messianic and historic is the idea that fulfillment is possible by retrieving and revoking foundation, by coming to terms with it."130 This messianic fulfillment would provide a response to the problem identified by Adorno of the perpetual, however micrological, remainder left over in the passage of things into concepts. The "conceptual utopia" that Adorno envisions and seeks to elucidate in Negative Dialectics is here given a slightly different formulation, and a more promising outlook, in Agamben's formulation of what is truly messianic.

129. Ibid., 99.

130. Ibid., 103-104. 


\title{
Utopia as "The Profane"
}

Agamben's repeated references to profanation almost certainly have as one point of reference the quote from Ludwig Feuerbach that begins Guy Debord's text The Society of the Spectacle:

\begin{abstract}
But certainly for the present age, which prefers the sign to the thing signified, the copy to the original, representation to reality, the appearance to the essence.. . illusion only is sacred, truth profane. Nay, sacredness is held to be enhanced in proportion as truth decreases and illusion increases, so that the highest degree of illusion comes to be the highest degree of sacredness. ${ }^{131}$
\end{abstract}

As noted, Agamben states repeatedly his admiration for and concurrence with Debord's analysis in this text, and his conviction that Debord's assessment of the critical issues and tasks of his time is correct and prescient. The appearance in the text, as a point of departure, of the structural opposition between sacred and profane, and its association with illusion and truth, resonates with emphases in Agamben's texts. Agamben emphatically presents profanation as something to be pursued, while sacredness is something to be interrogated and exposed in the context of the state, the state based on the capture of "bare life" as "sacred life." What might be worth noting is that the "bare life" that is "sacred" is called in official discourse and political speech "human life." This "human" life, however, is the "bare" life that the human shares with all other forms of life, rather than anything specifically human as to its form of life. That is, bare life is not some unique form of life that distinguishes the human form from any other life form. It is, rather, life without any particular quality other than its situation of being organized within a state that claims or can claim, and, according to Agamben's analysis, always claims in its foundation,

131. Ludwig Feuerbach, The Essence of Christianity, cited in Debord, Spectacle, 11 . 
a state of exception in which it includes an outside and excludes an inside.

Agamben's solution to the problem posed by bare life takes the form "the form-of-life [bios] of the human must coincide with its bare [zoē] life." The bare life that becomes profane rather than sacred - that is, that reverts to common use - must designate human life. It must at the same time coincide with that bare life that the state, in its state of exception, attempts to claim as its own. This analysis suggests that the stakes could not possibly be higher at the present moment for humanity and for the globe. The life that human beings share with all other living things, the "bare" life or nothing-but-a-live-being that is at stake in contemporary politics and praxis, is that without which there is no life at all, but only death.

The utopian moment, the only utopian possibility within the purview of these texts, lies in the possible extrication of life itself from its imprisonment in the core of the state, and its reversion to common use, for whatever being and purpose.

\section{Philosophy as Strategy and Intervention}

Agamben is yet another thinker for whom philosophy itself is a practice. From the perspective of utopian discourse, his thought concerns the root obstacles and possibilities for utopia, in the sense of a condition that ends practices and structures that produce suffering. Agamben's work is political practice in the form of theory that addresses the deep conceptual tap-roots of contemporary understandings and practices. His work bespeaks the conviction that seeing how ideas and associations arise, how they come to acquire their hold on the collective imagination and how they trace their trajectories of meaning and development matters. Homo Sacer offers a particularly apt example of this line of thinking. It locates the roots 
of the state form in the theorization of the Greek polis, and locates the treatment of "bare life" in the polis as the kernel of western political thinking. His identification of the negativity of language, and the analysis that roots contemporary nihilism in the functioning of language itself, offer another example of this style of thinking. Something akin to psychoanalysis in this method links Agamben's work to that of Irigaray. This theory amounts to an elucidation of how things came to be, as a result of choices made; this method then indicates places where other choices could have been, and perhaps could still be, made. Agamben's focus on original thinking underlying institutions suggests that institutions themselves carry with them, in their structures, the conceptual tendencies on which they have been built. The "building" metaphor suggests that some institutions cannot serve certain ends, by virtue of their original engineering. The task of thinking through this original engineering or architecture, then, becomes both vital and "strategic."

Durantaye notes that Agamben takes the issue of philosophy as strategy fully seriously. This strategic conviction coincides with his admiration for Debord and for Benjamin, both of whom he identifies as strategic thinkers and writers. Moreover, the realm of this strategic operation, in Agamben's view, includes the potentiality of the intellect and the various powers of life that are implicated in political ontology. Strategic choices cannot be narrowly political, but have to be taken at the level of first philosophy. The idea that political life involves simply pragmatic and superficial maneuvering is both foreign, and counterproductive. Instead, "political thought and political strategy have to reconnect with a lost ontological element," that takes them beyond immediate instrumental considerations, and makes 
political actors and thinkers aware of the stakes always already involved in their political practice. ${ }^{132}$

The impatience critics sometimes express with this style of thinking contributes to its appearance as an impractical form of utopianism. By calling such basic institutions and structures as language and the state into question, his work seems to invalidate all potential political activity. It is difficult to imagine political activity that is not oriented towards state power, and that does not function through the unexamined use of ordinary language. The difficulty of imagining such political activity may in fact be one index of its necessity. What emerges as the most profoundly utopian feature of this utopian discourse is its effort to facilitate radically different thinking, by means of calling into question categories and forms that well-intentioned political actors typically take for granted.

\section{Textual Form and Considerations of Language}

Agamben's texts are conventionally academic on one level: they address topics and make arguments. While they are not treatises of systematic philosophy, and while they rely heavily on philological methods which some critics question, they unfold conventionally, compared to texts by Adorno or Irigaray. At the same time, however, they embody methods of indirection, digression, illustration and unanticipated juxtaposition that create a striking mood, more like that of lyric poetry than the standard philosophical paper, and that encourage reflection on their implicit meanings. This effect is most evident in Idea of Prose, which consists of a series of fragments, incorporates line drawings and woodcuts as illustrations, and presumably aims to generate a response around what is not said as much as around what is.

132. Durantaye, 196. 
The claim that Agamben's texts aim to generate a response around what is not said as much as they do around what is requires extension. The generation of effects that, in a less linguistic medium might be labeled as employing "negative space," is a recurrent feature of Agamben's texts. The argument of The Open, for instance, leaves spaces around its presentation of facts and arguments for inference about the message of the text. Similarly, the text of The Coming Community relies heavily on intertextuality, resonance of one example with another, and aura to create its mesmerizing effect on the reader. In this respect, Agamben's texts resemble the medieval commentaries on sacred literature, and the philological glosses of the $19^{\text {th }}$ century, both of which he has expressed admiration for as creative forms. ${ }^{133}$

Indirection in Agamben's texts is related to the theory of representation he presents, and to his concern with a "pure potential for representation."134 The problem with representation in the integrated spectacular situation is that representation feeds and supports the spectacle's alienation of images from concrete possibilities. Representations of positive states, as images for contemplation, undermine what potential for activity might subsist. Readers who find nothing directly represented in a text, and who persist in efforts to engage with the text, are compelled to create their own solutions to this representational problem. These readers thereby experience their own potentiality for representation. Readers who undergo this experience may then be able to contribute to the constitution of a subject of utopian possibility.

133. Agamben, Infancy and History, 144; Durantaye, Agamben, 126. 134. Durantaye, Agamben, 121-147. 
The Problem of Language from a Utopian Perspective

Language is intrinsically alienating. To appear as a subject within language, the speaker - the subject of the enunciation - must adopt a universal position via one of the personal pronouns known as "shifters." So, for instance, "I" does not refer exclusively to the particular or singular person making a particular enunciation, but is a universal position shared with all other speakers who are capable of saying "I" under appropriate circumstances. Perhaps paradoxically, then, the use of these shifters, which arguably helps form the psychological subject, is in tension with the articulation of a radically singular perception, history, or position. If by the subject someone might want to denote the singular existence dealt with carefully in The Coming Community, whatever being, language turns out to be a blunt instrument.

Language and Death, Infancy and History, and Remnants of Auschwitz all point to a phenomenon of language that makes speech about or from the place that would seem most immediately accessible to an individual precisely least accessible, and indeed foreclosed. Agamben's texts identify this foreclosure as central, definitive of the western tradition, and deeply influential in the present context he identifies as "nihilism."

The aporia or dilemma is that a person, to enter into speech and to make a reference to a personal experiential existential subject, must deny or alienate a portion of the truth of that subject, in order to participate in the linguistic world that is that person's inheritance. As far as any existing linguistic theory knows, the phenomenon of personal foreclosure happens in every language, since every language contains what Benveniste identified as "shifters," which make reference only to the instance of discourse, and which can thus be seen to change their meaning or rather not to have a stable meaning when they are 
decontextualized, as they inevitably are over time. Insofar as they represent or point to the instance of discourse in its originary place, time, and context they have one truth content; insofar as they represent or point to the taking place of discourse in general, any possible context of discourse, they may or may not lack all truth content. ${ }^{135}$ Moreover, a speaker or writer, an individual practitioner of enunciation, undergoes an unavoidable self-alienation in taking up the position of the speaking subject, and simultaneously perpetrates an unavoidable effacement of the specificity and concreteness of others in taking up the position of the intersubjective references coded in a language's personal pronouns.

The logic of the argument goes something like this: "I", a personal pronoun, refers not to a specific concrete subject, but to a situation of discourse; it denotes "the specific concrete individual uttering the given instance of discourse." As such, the word "I," viewed from one direction, is the most personal and specific of words. But viewed from another angle is the most impersonal and general of words. In taking up the use of the personal pronoun "I", a speaker or writer identifies himself or herself as the "place of the taking place of language," but as the place of the taking place of language, which can be a condition shared with many, this place becomes a place where the immediate, personal, specific, concrete predicates of the speaking subject disappear, or are silenced in the taking place of language in general. The phenomenon of silencing remains in effect, regardless of the specific content of the discourse, even when the discourse

135. Whether a word "represents" a concept or function, or whether it "points to" a concept or function makes a theoretical and practical difference, and these terms signal the tension between a representational and a semiotic understanding of language. The differences between representational and semiotic theories of language are far beyond the scope of this work. 
describes a series of intensely or emphatically personal predicates, of any kind.

In an everyday pragmatic register, such logic appears ridiculous. A statement of the form "I've lost my car keys" or "I'm Iosing my religion" is fairly clear and communicates something to a participant in the original discourse, something concrete and fairly precise in most contexts. Most people don't recognize, or feel, their intense self-alienation in speech when they utter enunciations of that form. If people did, very little of the ordinary business of living, from functional to tender, would occur. The argument that the everyday pragmatic context and its demands are exclusively inauthentic, the realm of das Mann and so on, deserves to be questioned. Tucking children into bed at night, for instance, is not the appropriate context for confronting one's being-towards-death and its doubling in language - not to say it does not become such an occasion rather routinely - and is certainly not ordinarily the context for sharing such reflections with the other as other. It is rather, normally, the context for accepting the grace of immediacy and communicability.

But when the context for reflection and deeper consideration presents itself, when the car keys have been found and the day's calendar arranged and when the child is asleep, the logic presents itself as more compelling. It reasserts itself in reading texts, and in particular sacred texts, that make use of personal pronouns: "Deliver me according to my righteousness," "let not your right hand know what your left hand does," "oh you of faith," and so on. The discourse goes on, long after its context has altered. The specific addressees seem interchangeable - and yet, are in other ways not interchangeable, and in the distance between this interchangeability and this noninterchangeability, this sensed non-"fungibility" in the terms of 
Adorno, this "not same" in the terms of Irigaray, lies the concrete individual's sense of the death of the self and the barrier of language in the encounter with language and speaking. The communication of the personal, specific, concrete, irreproducible individual subject, the communication of the truth of this subject, and particularly of the communication of its full truth, continues to elude those subjects, even in language, whenever that truth is separated from its everyday pragmatic context. Nevertheless, the sense that there exists some truth that fails to enter or to be visible in that everyday pragmatic context also bedevils these subjects.

In other words, the essential negativity of the foundation of authentic being in "being the there" or "grasping the this" understood as the "taking place of language," and the death of the existential or phenomenological subject in a Voice that calls to the place of the taking place of language, is what Agamben's study exposes for consideration. What is exposed in that analysis is that the western tradition seeks something like "the mystery of Iife," or the source of individual consciousness, in the very moment of its loss in language, a loss which can be perceived as a loss only at a remove from commonplace life, a remove from the "prosaic," everyday pragmatic register into the register of separated reflection.

In separation, moreover, is to be understood not a complete separation but a shift of emphasis or focus, with a commensurate forgetting of or de-emphasis on the concrete realities that enable and necessitate the taking up of the everyday pragmatic register, which cannot be done without even for a moment.

This logic underlies Agamben's "philosophy of witness" or "ethics of witness." In Remnants of Auschwitz, Agamben identifies an "experimentum linguae" (an experiment of language) that pertains to 
"bearing witness." Catherine Mills criticizes Agamben's philosophy of witness, in her final analysis, for its "non-relationality." Whether this criticism stands deserves careful consideration. It would seem that inter-relationality, inter-subjectivity, would be one of the presuppositions or prerequisites of something like "bearing witness," as the audience for the testimony would be required. The citation of Nietzsche's discourse on the "last man" suggests as much, that the relationship of self-referentiality and the splitting of the individual subject into producer and consumer, sender and receiver, thought and intellect, "it" and "I", continues even into the thoughts of the "last man." Why does the text label this experiment an experiment of language? The answer to the question arises from a consideration of the example, or incident of Hurbinek, a "child of Auschwitz," who cannot speak language although he is about three years old, and whose story is related in Primo Levi's memoir The Drowned and the Saved. ${ }^{136}$ At one point Hurbinek begins to repeat a sequence of sounds that Levi and his fellow prisoners think might be a word or a name, but which none recognize. It seems to be an insistent effort to communicate. The word, or name, remains forever unintelligible, however. Some days after this initial effort at speech, the boy dies.

Agamben points out that "Hurbinek cannot bear witness, since he does not have language," that is, the sounds that emerge from him do not take the form of words known to the others who might relate to him. The others recognize his word as a word, or something like a word, but not its meaning. Levi says of him "he bears witness through these words of mine."137 Agamben's commentary identifies a double exclusion from testimony, which bears witness "completely" through the vehicle of

136. Primo Levi, The Drowned and the Saved, trans. Raymond Rosenthal (New York: Summit Books, 1988).

137. Agamben, Remnants of Auschwitz, 38. 
Levi's language. For Agamben, Hurbinek becomes the exemplar of the complete witness, whose language of testimony "no longer signifies and that, in not signifying, advances into what is without language, to the point of taking on a different insignificance - that of the complete witness, that of he who by definition cannot bear witness."138 The text points us toward the recognition that what is at stake in the "true testimony" or the testimony from someone who could speak from experience, someone who had both been there and had seen and experienced the experience of the camps, it is not enough to be in the presence of the non-sense of language itself, but rather "that this senseless sound be, in turn, the voice of something or someone that, for entirely other reasons, cannot bear witness."139

The would-be witness cannot bear complete witness because that witness has not seen everything there was to see, and has not experienced everything that could have been experienced. So to the reality of having seen all that could have been seen, or experienced all that could have been experienced, no one can bear witness by definition, because the possibility of a voice or speech arising from that place is definitively exhausted. But for Agamben, this "lacuna" of testimony, in which the witness cannot provide the adequate witness because of the inadequacy of language, because of the foreclosure of the personal in and through language, must "give way" to the different impossibility of bearing witness that arises from not having language. On the other hand, what will be decisive for the inhabitants of the coming community will be an appropriation of the being-in-language Agamben depicts as that which is most common to humanity. His analysis of the Platonic idea in The Coming Community indicates something of

138. Ibid., 39.

139. Ibid. 
what he is trying to accomplish through his meditations on language. He encourages an appropriation of humans' own "being-in-language," which amounts to an appropriation of humans' status as related both to the concept of humanity and the idea - that is, the "thing itself" - of humanity. "Only those who succeed in carrying it to completion without allowing what reveals to remain veiled in the nothingness that reveals, but bringing language itself to language - will be the first citizens of a community with neither presuppositions nor a State . . ."140

His analysis here is reminiscent of Adorno's treatment of subject and object, and of the problem of the "non-identity" between the object and its covering concept. Agamben resorts to Aristotle's treatment of synonymy and homonymy to make his argument. Individual instances of a nominal class or category (e.g., "horse") are Aristotelian "synonyms" with respect to that class; they are "homonyms" with respect to the "idea," or in Agamben's terms "having-name."141 While it is possible to point to this as "being-in-language," the idea itself has no name of its own; it is hidden under the linguistic word, that is always welded to its concept. Hovering around that word, however, is everything discernible in the "whatever" being that remains non-linguistic while being in language. ${ }^{142} \mathrm{All}$ those microscopic features that cannot solidify as predicates of the concept are nevertheless the very essence of "whatever being"; these are the "smallest intramundane traits" noted by Adorno as being "of relevance to the absolute."143 At this point, Agamben's analysis of whatever being and Adorno's analysis of the goal of negative dialectics radically converge.

140. Agamben, Coming Community, 83.

141. Ibid., 75

142. Ibid., 76 .

143. Adorno, Negative Dialectics, 
Treatment of Subject-Object Relationship

For Agamben, in effect, the experience of language and whatever being's being-in-language joins tongue in groove to the problem of the relationship of subject to object, however it is conceived. What it might mean concretely to appropriate one's own being-in-language is not immediately clear. Agamben's example, of Tiananmen, leaves almost everything to the imagination. What it does not leave to the imagination is the prediction that whatever appropriation of being-inlanguage will be undertaken by these citizens of the coming community will excite the opposition of the State. What forms this appropriation of being-in-language might take, and how those forms of community are to find ways to co-exist with, avoid, or deconstruct the state is left as an exercise for the reader.

That exercise is, in fact, far from incidental. Agamben ultimately poses a strongly autopoietic thesis of the subject, that emerges from the ruin of the western philosophical effort to identify an objective ground for this subject that gives it substance and direction. This effort itself constitutes the objective historical foundation of western nihilism. Its theoretical version culminates with Hegel and Heidegger both announcing the negativity at the center of subjectivity, and which is also reflected in the poetry of the stil novo and its acknowledgement of talk about "nothing." Its translation into practice is illustrated most decisively by the Nazi death camps, but has become the paradigm of contemporary global politics. The triumph of the integrated spectacle has stripped language of every substantive content, rendering language itself discernible as an apparatus of noncommunication. ${ }^{144}$

144. It seems necessary to recall at this point that language is also not fully an apparatus of non-communication, even for Agamben. 
The exigency of coming to grips with this evident negativity has been a theme in Agamben's work from his first book, The Man without Content. There, Agamben quotes Nietzsche, in the preface to the Gay Science, saying "Ah, if you could really understand why we of all people need art . . ." but "another kind of art. . . an art for artists, for artists only!"145 Agamben's thesis in The Man Without Content is that the creative act faces the modern artist with a profound threat, a terrorizing experience. What is supposed to be "self-expression" becomes a profound realization of an absence of content for expression. This confrontation with the absence of the fixed human subject, along with the absolute dissolution of a tradition that provides determinate content for the working out of human subjectivity, underlies the problem of the artist, as well as that of the arts, in the contemporary period.

Agamben's ties to the Situationist International, which endeavored to transform society through a free creative use of what is available, connects with the formlessness and absence of a determinate work to which the human person is "called." That art, an art without determinate contents, that is so urgently needed, then must be an art for artists, in a world in which everyone is required to become an artist. Here, his final meditation on Benjamin and the question of tradition and transmissibility has to do with the resignification of meaning. What emerges from Agamben's discussion of Benjamin's interest in quotation, his comments on the collector, and his thoughts about the past, is that the past can be an alien body. If for Adorno the extent to which the past forms the present subject figures prominently as an

145. Agamben, The Man Without Content, 7. The first edition of The Man Without Content, published in 1970, coincided with the original German publication of Adorno's posthumous Aesthetic Theory, Adorno's last work thus coinciding with Agamben's first. 
obstacle to action, for Agamben the extent to which Benjamin "makes alienation from the past into a value" signals the possibility of a more revolutionary relationship to the past. ${ }^{146}$

Agamben draws a contrast between a traditional and a contemporary culture. In contemporary culture, aesthetics is founded on the destruction of the transmissibility of culture, of tradition. In a traditional culture, "an absolute identity exists between the act of transmission and the thing transmitted."147 Culture is not a vehicle for the transmission of something other than itself, some body of knowledge or special truth. Rather, culture just is the flow of what people know, are, and can be. "For it is the transmissiblity of culture that, by endowing culture with an immediately perceptible meaning and value, allows man to move freely toward the future without being hindered by the burden of the past."148 The past is not in those circumstances something heavy and alien with which each person must come to terms in some way. Rather, the past travels with the present, lightly, as whatever continues to be of use. People today have lost this relationship to culture.

Durantaye suggests that Agamben sees the role of art as being to guide people, show them who they are, and indicate to them what they can do and become. Art no longer simply fulfills this function for moderns and post-moderns. In this, Agamben and Adorno see something similar. Durantaye, however, may not take seriously enough Agamben's interest in and homage to the situationist project, or its relationship to Benjamin's notion of the constellation, or its relationship to his own concept of "making use" of things in a profane way. Maybe everyone

146. Ibid., 105.

147. Ibid., 107.

148. Ibid., 108. 
does not need to become a poet, as Durantaye worries. ${ }^{149}$ But the "art for artists only" that Nietzsche calls for, a call that Agamben echoes, does have something vital to do with the status of producer, the technikēs, that each person is required to assume. The reservation of this humble status to "the creative activity of the genius who is burdened with the imperative to produce beauty" is the mark of the destruction of culture as a place of human habitation. ${ }^{150}$ What is called for is an active reappropriation of this process not as a return but as a new creatively technical endeavor. Durantaye's remarks on The Man Without Content are perspicuous; the potential confusion involves the extent to which the tradition and transmission of culture take place in the oikos, the realm less of "art" than of "craft." That distinction, which is itself a product of the rise of aesthetics, with its segregation of "high art" and its relationship to a culture that could not be transmitted organically, needs to be borne in mind. The humble technikēs was never an artist in the modern sense of that term, and the anonymous détourniste who might be heir to that earlier function similarly will not be "that kind of poet" even though she is in effect reasserting humanity's "poetic dwelling."151

The meditation on time and rhythm that Agamben begins in The Man Without Content comes to fruition in The Time That Remains. Agamben thus succeeds in linking religion and art or aesthetics, and in drawing

149. Durantaye, Agamben, 37.

150. Agamben, Man Without Content, 111.

151. "Poetically man dwells on earth," presumably the literary referent of Agamben's statement of "man's poetic status on earth," comes from a poem by Hölderlin, "In lovely blueness." The line is taken up in a 1951 essay by Heidegger, ". . Poetically Man Dwells..." See Martin Heidegger, ". . Poetically Man Dwells.. .", trans. Albert Hofstadter, in Philosophical and Political Writings, ed. Manfred Stassen (New York: Continuum, 2006) 265-278. Perhaps significantly, in this essay, Heidegger makes a comment on potential: human beings can fail to dwell poetically on earth because they also can succeed in dwelling in this way. If they had no potential to dwell poetically, it would be pointless to say they do not do it. Agamben is more likely to reverse this logic: if humanity dwells unpoetically, it could also not dwell unpoetically. 
out what might be their messianic potential for contemporary human beings. Contemporary human beings are those who, as Agamben notes, have lost their standing in a secure present, who have lost control of their gestures, who no longer have the capacity for experience, who, in effect, are utterly lost in the face of an objective that is at hand but to which there is no way, precisely because it is at hand. However, while it remains true that human beings have no essential work, that is, have nothing they must do, they have as a potential a kind of rhythmic character, an ability to mix form with substance, and to effect a pause between past and present, that can constitute the rhythmic, poetic appropriation of time into meaning. The messianic is, it seems, one way that people might take a new kind of hold on the past and occupy the present as the caesura or epoché between past and future, in a manner that does not leave the past as an oppressive and alien force hanging threateningly over human life.

Recognizing this subjective potential, then, involves a renegotiated understanding of space and time. It eliminates presuppositions, but leaves what we might still want to call subjects, or "whatever being," free to make a profane or playful use of the full range of materials available to contemporary life. This subject would have the potential to create, from the nothing that is human life, that form that would be inseparable from life that constitutes ethics, and to suggest and guide through formation into a world that would offer the happiness, and end the suffering, that everywhere and always has borne the name of utopia. In other words, the utopian chronotope is the space-time that humanity in itself is - at least, potentially.

\section{The Space and Time of Potentiality}

As noted previously, subjects of utopian possibility need both space and time that are sufficiently open to permit action. Space 
cannot be so dense, or so tightly controlled, as to prevent action that challenges the unspeakable world that is. The structure of time must be such that action can occur. What can take place in it cannot be completely determined by what has taken place in the past, or abandoned to an invisible telos presumably to arrive in the future. Agamben's treatment of these two issues contributes to a distinctive understanding of "whatever being" as that subject of possibility that is in a position to undertake a messianic form of activity. That activity makes use of the "time of the now" (the Pauline ho nyn kairos that Agamben links to Benjamin's Jetztzeit) that is "shot through with messianic time."

The Outside Inside

Agamben's approach to the space of action involves recognizing the presence of an outside already inside, at the heart of the structures of western life. The state of exception that is the rule of political Iife in the contemporary period has the structure of a capture of an exclusion, the incorporation of something - like bare life - in the form of its exclusion, and the exclusion of something that is already presupposed and within. The potentiality that resides in this structure has to do with the exteriority that has already been set up as the innermost cell of the state of exception.

The "whatever being" that is the core concern of The Coming Community is particularly important here. First, whatever being constitutes "the event of an outside" in its relationship to humanity. ${ }^{152}$ It does this in a precise and predictably singular way, by inhabiting a relationship to an idea. This relationship makes "whatever being" a "threshold," "a point of contact with an external space that must

152. Agamben, The Coming Community, 67 . 
remain empty."153 This outside, understood in terms of something like a threshold or something that is "at the door," can also be thought of as the passage that makes a determinate space accessible, its "face" or its eidos - its form. ${ }^{154}$ Agamben's statement on this point is worth quoting at length:

The threshold is not, in this sense, another thing with respect to the limit; it is, so to speak, the experience of the limit itself, the experience of being-within an outside. This ek-stasis is the gift that singularity gathers from the empty hands of humanity. ${ }^{155}$

In other words, "whatever being," this event of an outside, is also an experience of this outside as something whatever being inhabits or stands within. This makes whatever being simultaneously an experience of standing within - within the threshold and the "outside" which it is in itself - and of standing "without" or "outside," in a Heideggerian "ek-stasis" - outside the "empty and indeterminate totality," called "humanity," that delimits the space of belonging. ${ }^{156}$

of note is that the structure of whatever being, which is the experience of being-within an outside, is precisely counterposed to the structure of the state of exception. The state of exception is structured as the capture of an ex-clusion in the form of an in-clusion or in-corporation. This ex-clusion is specifically an in-clusion, or presupposition. This structure, which appears obsessively in Agamben's work, perhaps because it appears obsessively in the structures of western thought, is associated in Agamben's work in every case with the threat of death. In the form of the anthropological machine, it is deadly. In the form of the camp, the nomos of modern political life, it

153. Ibid.

154. The Platonic term appears in the text with dramatic emphasis.

155. Ibid., 68 .

156. Ibid., 67. 
is the precondition for annihilation. In the form of the sovereign state, it is the exposure of sacred life to death.

In State of Exception Agamben "speaks, in regard to the state of exception, of a 'no-man's-land' he sees lying between 'civil law and political fact'" that then opens the potential for a reversal of the state of exception itself, or rather, for an institution of new categories. ${ }^{157}$ Agamben is taking his analysis of the state of exception as is well-known from Walter Benjamin's $8^{\text {th }}$ thesis on history, which calls for a real state of exception that would "better our position against fascism," and which Agamben seems to believe has come into its own "now of legibility."

But we have seen the perception of a space between two positions already, both in Adorno and in Irigaray. This is not the first time we recognize a "between" that has been labeled utopian, for in Adorno the "no-man's-land" is explicitly a potentially utopian space. In Irigaray, the space between two, which is only barely perceptible and is indeed imperceptible for those who refuse to recognize the subject position of Woman, is the place where a utopian future might begin, in encounter. Agamben also illustrates this space in the between "man and animal" of "the open", and in fact this space between constitutes the open.

In the innermost cell of these structures of lethality, therefore, a perpetual spaciousness abides. That spaciousness is intrinsic to the ontological structure of the being, whatever being, these structures have formed to contain, maintain, retain and restrain. Its potential, which is always an exteriority, is inexhaustible. The task of the coming community will be to open up this event of the outside, constituted by the relation of "humanity" to its singularity. In an alternative formulation, it will be to transform the "biopolitical body 157. Durantaye, Agamben, 338. 
that is bare life.. . into the site for the constitution and installation of a form of life that is wholly exhausted in bare life and a bios that is only its own zoè."158 "That is, it seems, roughly equivalent to finding a way to refuse the temptation to render abject and expendable one or another specific singular manifestation of the life that living beings share, and learn how simply to live, together.

The distance between this formulation and the classical description of utopia as the ultimate reconciliation of humanity with nature is micrological, as well as real and consequential. It is precisely the difference, following Agamben's analysis, between a form that makes the space accessible to the kind of thought that might be able to make use of it, and the kind of thought that can only work obsessively to abandon it to containment. In Agamben's sense the only available space for practice is always already fully occupied by zoe. The good news is that the space is always already accessible. The bad news is that the singularities who will be in a position to make use of it are still irreparably factical, for better or worse. Moreover, they still need to see the possibilities, and to cultivate the preference for not doing otherwise than making use of them.

Time

A bios that is at every point its own zoé, equivalent to a form of life that fully exhausts itself in life itself, will have a particular relationship to time as well as to space. That time is always available, and in Agamben's treatment seems to constitute the Jetztzeit, the "time of the now," or the ho nyn kairos of the Pauline formulation. In fact, it bears an intimate relationship to the time that humans represent, in whatever way, in the tenses of language and the turns of phrase that create images and representations of time.

158. Agamben, Homo Sacer, 188. 
To elucidate this point, Agamben draws first on a linguistic analysis that terms "operational time" as the time it takes for someone to form a linguistic representation of time. He then makes the connection between this "operational time" and the familiar theory of shifters developed by Benveniste, pointing out that this operational time is what opens the possibility for language to refer to its own taking place. It also provides the basis for a striking note, regarding the self-presence of consciousness, that points out that lapse and delay, a dissynchrony, inhabits the core of the subject that is, as Benveniste's theory goes, constituted linguistically. The experience of self-presence, for this reason, takes the form of the experience of time. Agamben then extends this discussion to the realm outside linguistics and discourse.

"It is as though man [sic], insofar as he is a thinking and speaking being, produced an additional time with regard to chronological time, a time that prevented him from perfectly coinciding with the time out of which he could make images and representations. This ulterior time, nevertheless, is not another time, it is not a supplementary time added on from outside to chronological time. Rather, it is something like a time within time. . . which . . allows for the possibility of my achieving and taking hold of it." 159

Agamben's designation of this intimate, operational time as time humankind produces in its life as thinking and speaking beings is of particular interest in the context of Agamben's theoretical relationship to Debord. According to Debord, "By demanding to live the historical time that it creates, the proletariat discovers the simple, unforgettable core of its revolutionary project."160 The vehicle for doing this may be the operational time that Agamben identifies here. He defines "messianic time," in light of this operational time, as "the

159. Agamben, The Time That Remains, 67.

160. Debord, Society of the Spectacle, 106. 
time that time takes to come to an end."161 Messianic time can be understood as the livable, usable time that affords an opportunity for radical action, produced from within the seemingly seamless and closed context of the spectacle.

Agamben labors to clear up a number of actual and still potential misconceptions with respect to this messianic time. First, messianic time elucidates something about the relationship of kairos, or "occasion," to chronos, or chronological time, the time that passes in regular rhythm and whose passing can be measured by clocks and calendars. He notes that any kairos always has at its disposal chronos, in effect has no other time than chronos to provide it with substance, making it something graspable. Messianic kairos is, in the end, nothing other than "seized chronos," not some additional or other kind of time. ${ }^{162}$ Implicit in this analysis is that all chronos is potentially kairos. Kairos consists, ultimately, of ordinary time in the aspect of its having been seized in and for a use specific to an occasion. Similarly, the parousia involved in Paul's discussion is not something supplemental that can be added on to the representation of time. The messianic community might be depicted as living its life in endless deferral, but this is not the Pauline picture, according to Agamben. Rather, the parousia already establishes a time of the now, which lengthens out, not in order to endlessly defer its fulfillment, but so that its instantaneous present character can be grasped. Here Agamben has recourse to Kafka's comment that the Messiah will not come on the last day, but on the very last day. Agamben sees the same structure, of the stretching out of time, at work in Paul's texts.

161. Agamben, Time That Remains, 67. 162. Ibid., 69 . 
Agamben's discussion of the figures appropriate to messianic time sheds additional light on this peculiar and vital structure of possibility. Pauline typos, the relation of a figure in the past to a figure of or in the future, is one of these structures. Recapitulation, sometimes referred to as "summing up," is another. Messianic time involves a "summary judgment" and fulfillment or fullness of time, including in its historical dimension. In both these temporal and discursive structures, there is an irreducible activity implied on the part of the messianic community, the messianic actors who live in messianic time. The typological relation is not eternal, but specifically created or constructed, held together and realized in the time of the now. The recapitulation of summary judgment, or of recognizing how events in a present complete and modify events of the past, is also a production of activity in the now time. For this reason, Agamben emphasizes that messianic time is emphatically not oriented solely, or even primarily, towards the future, but rather towards the past and its relationship to the future, as well as to the present. It represents a decisive settling of accounts and revelation of the potential still locked up in memories and images of the past. ${ }^{163}$

The Very Topia of Things

Agamben's work is both radically revolutionary, and profoundly utopian, in the thoroughly obscure way that a blank page is thoroughly obscure. He has been described as reactionary as well as utopian. Zizek makes him the representative of the position, with respect to the "full hegemony of global capitalism and its political supplement, liberal democracy," of "acceptance of the futility of all struggle" and an associated passive waiting for an outburst of "divine violence."164 The

163. Ibid., 77.

164. Žižek, ibid., 337-338. 
reading presented here does not support that assessment. Rather, it sees Agamben's work as a radical rethinking of the political bases on which current western forms of life rest. Implicitly, his work continues to insist that a refusal to address the intrinsic lethality of these forms, and a continued embrace of these forms, will continue to undermine efforts to construct the messianic community that he would stress needs to be brought into being. That community would have the potential to seize the time of the now, the time that human beings themselves create in their common lives and works, and make use of it to bring the oppressive accumulation of historical time to an end.

This positive assessment of the core of Agamben's thought does not mitigate the criticisms that, as noted, are legitimate foci of attention. Practical questions remain. Chief among these are the negotiation of the practical problem of how to make use of distinctions and divisions that have a history of oppressive use in ways that restage and neutralize their oppressive force. How, in other words, can the distinctions involved in sexual difference, for instance, be made use of for the purposes of creating new forms of subjectivity, while pursuing a form of "messianic community" that eschews a foundation on the basis of presupposition or identity, both of which generate exclusion and abjection?

This reading of Agamben's work nevertheless discerns a potentiating framework. That framework provides for the discernment and cultivation of a subject of utopian possibility by means of a making use of what is available to whatever being in the present circumstance, even the dire circumstances of the integrated spectacle. That includes language, relationships, and the space and time both of bare life and of a reengineered poetic dwelling. What might motivate such a free use could be the promise of happiness contained in the announcement of the 
possibility of this form-of-life, the form of which remains unspecified, unrepresentable, and unforgettable. 
CHAPTER V

MESSIANIC LIGHTING

\section{Introduction - The Subject of Utopia}

\section{Sumary}

This investigation of utopian discourse in the work of Theodor $W$. Adorno, Luce Irigaray and Giorgio Agamben has observed that each of these writers addresses what could be termed a "subject of utopian possibility." This subject might be capable of thinking a vitally necessary alternative to what presents itself as reality, and perhaps even of undertaking the poetic task of fashioning that alternative. Their shared address to this subject of possibility, and their shared refusal to specify the contents of this alternative, signal a more fundamental commonality. Each of these authors pursues a similar direction in developing a minimally and sufficiently metaphysical position that might maintain itself in a materialist, post-metaphysical context. That is, each of these authors pursues a project that aims to satisfy the metaphysical condition for utopian imagination, with the possible effect of augmenting its practical import.

The Subject of Utopia

As noted earlier, there are at least two ways to understand the phrase "the subject of utopia" that are relevant to the study of utopian discourse that has been pursued here. "The subject" can mean the subject of a sentence: the word that does the action of the verb, that undergoes the experience of something, or that bears the 
description of a predicate. By extension, it can mean the occupant of the subject position sketched by that grammar. Alternatively, the word "subject" can point towards some matter under discussion, the main theme of a conversation, work or course of study.

One conclusion of this comparison of utopian discourse in works by Adorno, Irigaray and Agamben is that these three thinkers take similar positions on the subject of utopia in both of these senses. With respect to the subject of utopia in the first sense, they discourage the idea that their readers are, or might at any moment become, subjects of utopia. Their texts address fellow subjects of dystopia. They refuse to delineate the as-yet-unmet subject of utopia. With respect to the subject of utopia in the second sense, they share the "iconoclastic" mode identified by Russell Jacoby, that eschews detailed representation of the utopian condition. ${ }^{1}$ In the case of Agamben, this avoidance of representation has even been labeled a formal "antiutopia." 2

A second conclusion is that despite these refusals of utopian representation these three thinkers nevertheless participate in utopian discourse. They do this by producing a specific form of utopian discourse that works to cultivate the idea of possibility on which utopian imagination depends. This cultivation includes the development of an account of something like metaphysical experience that can be tenable in a post-metaphysical context. This account, broadly similar across the different writers' works, is addressed to a subject, in the first sense, of utopian possibility. The subject of possibility is in a position to exercise utopian imagination, and in time to consider active participation in a utopian project. Utopian discourse here is

1. Jacoby, ibid.

2. Salzani, ibid. 
not a discourse that describes utopia, but one that constructs subjectivity with respect to an open horizon of utopian possibility.

That effort at utopian imagination may be arduous; that utopian project may be miniscule. The texts' invitation can certainly be refused or ignored; these texts are neither coercive nor invariably persuasive. In fact, as previously noted, they have earned their reputation for repeliing readers as much as for enticing them. However, people call these writers "utopian" for a reason. That reason includes their insistent recruitment of a subject of utopian possibility.

A final conclusion is that what makes this discourse utopian is how it engages in and encourages further talk about "possibility" in the sense of "subject matter." Utopian discourse is metaphysical discourse; in a post-metaphysical age, it is impossible discourse. Each of these authors nevertheless pursues this impossible, but imperative, synchronization of a tenable metaphysical position with a strictly material, post-metaphysical world. Each finally locates this utopian possibility in solidarity with the matter of suffering. The subject of possibility takes place, where and when it takes place, in close proximity to a subject matter which transcends the discursive subject, even though the discursive subject could also be said to transcend that particular suffering. The "messianic light" these authors glimpse is material. Suffering matter itself constitutes the metaphysical substance that might make, and may suffer, the promise of utopian happiness. The suffering of this promise may, furthermore, lead to a practice of oppositional thinking and acting that could yet materially alter the dystopian context.

This chapter lays out the case for these conclusions. It first discusses how the address to subjects of dystopia works to constitute the subject of possibility. This discussion summarizes structural 
similarities across the three authors, noting significant differences. It then turns more specifically to the way these texts delineate the subject of possibility as subject matter. Here, it argues, these writers share an approach that locates in the subject matter of suffering itself the persistent conditions for utopian possibility. This material constitutes the potential for collaboration in the creation of the indispensable event of an "outside" or "other." This exteriority, in turn, is the critical event on which the possibility of utopian imagination depends. By recognizing suffering matter as the location of this minimally but sufficiently metaphysical difference, these thinkers identify an alternative and largely overlooked place from which to pursue the "negation of suffering" that is the constitutive content of utopia. The negation of suffering that proceeds from this place proceeds differently from those approaches to utopia that have relied on the domination of "nature;" it promises to create a different form of negation. A response to suffering from this place proposes, though not without ongoing risk, to elude the dystopian consequences of more properly metaphysical approaches on one hand, and of "anti-metaphysical" materialisms on the other.

In the end, the "messianic light" associated with utopia is a material, and for that reason promising, semblance - or poetic practice - of transcendence. This insight situates the "weak messianic" moment in this utopian discourse in relation to the "subject of utopian possibility" which the discourse addresses and discursively constitutes. Critical Comparisons

One Dystopian Assessment in Three Parts

Each of these authors pronounces a dire dystopian assessment. The specific assessments differ, but are nonetheless compatible with one 
another. A single account could be pieced together from these singular dystopian assessments.

This emergent account would not be a scholastic variation on one of the familiar critical themes of the late $20^{\text {th }}$ century. Although it suggests the presence of something like a root oppression, it does not lend itself to the idea that resolving this root oppression will tidily revolutionize reality. Nor is the root a familiar one, already thematized by critical theorists of one stripe or another. None of these accounts would satisfy partisans of Marxian class analysis, for instance. Class is not the fundamental variable in these dystopian assessments, and the active participation of the revolutionary subject in the dystopian state of affairs is one of the problems. None would fully satisfy the demands of feminists, multiculturalists, or postmodernist linguistic analysts.

Instead, these accounts identify systemic practices as the central problems that become the core obstacles to utopian happiness. Adorno targets a complex of instrumental reason, reification and fetishized commodity exchange that acts out the dynamics of an approach to logic that imposes equivalence on unlike phenomena, a reliance on abstraction that disregards its ineluctable inaccuracies, and an acceptance of the alienation of consciousness from its contents. In effect, he sees a need to rewrite the western script for the production of knowledge. Irigaray identifies the dystopian problem as the ongoing repression of sexual difference, which is cause and consequence of a foreclosure of feminine insight, language, and subjectivity, as a pervasive culturewide practice with psychological and linguistic underpinnings and systemic socio-economic, political and ethical consequences. Agamben returns again and again to the recurrent structure of the state of exception as the culprit in a structural bind in which western 
civilization finds itself, but investigates the way it plays itself out across a range of phenomena, from the politics of the sovereign state to the conceptualization of the relationship of human and animal to the importance of the contemporary relationship between artist and audience.

If there is a single thing that could be changed, which would realign the forces of society, for these authors, it is not as simple and concrete as money was for Thomas More. And yet, it can be argued that there is a single thing, and that the compatibility of the different accounts is secured by the fact that the thing is the same for each of these theorists. The root problem they each identify is the ineradicable participation of physical or material life in every moment of human transcendence, whether individual or collective, along with the persistent denial and suppression of this participation by the dominant accounts of reality.

The Enlightenment rationality Adorno and Horkheimer identify in Dialectics of Enlightenment, which strives to dominate nature while denying its own participation in nature, can be explicated further by Irigaray's analysis of the foreclosure of the feminine precisely because of the fundamental similarity of the process involved. The foreclosure of the feminine would be explicated further by Agamben's identification of the structure of the state of exception, which is paradigmatically that of an exclusion that is an inclusion, an inclusion that is an exclusion, although Agamben himself does not make the move of reading the state of exception in relation to gender. ${ }^{3}$ These different analyses do not simply reduce to "the same thing;" they are saying different things, and focusing on different aspects of the dystopian problem. The specific dynamics they identify, however, mesh

3. That he does not has been one source of criticism of Agamben's treatment of his material. See Mills, ibid., 114-115. 
with one another in time and space. In effect, they demonstrate themselves to be different aspects or coordinates of the same dystopian constellation.

The significant similarity in these accounts has to do with the role of inarticulate matter, which linguistic or ideological consciousness presents as "nature," "woman," "bare life," or "the given." Inarticulate matter, which conventional wisdom sometimes regards as the stuff of objective reality, is also the very site of dystopian suffering. It is related to consciousness as its consciousness's - place and time of possibility, and as its source for alternative realities. It is only "given reality" from one, narrow, point of view, the point of view according to which "nothing changes." It is also, perpetually, the concrete site of possibility. Because of this, the cultivation of a form of consciousness that attends to and respects this source of intelligence, both in its difference from the abstractions in which it may be apprehended linguistically and conceptually, and in its struggle to surpass the restrictions it experiences in "reality," is central to the cultivation of utopian imagination .

\section{Dystopian Suffering}

The suffering of inarticulate matter, however conceptualized, is the ultimate dystopian index for these theorists. The dystopian situation effectively denies and forecloses a reality or a portion of reality that depends on a perduring material substrate. That reality whether thematized as the Adornian concrete, Irigarayan Woman, Agamben's radical singularity of whatever being, or something else dwells constitutively and intimately within human life, and suffers from its relegation to mute obscurity and the consequent misapprehension or denial of its needs. Whether that mute obscurity 
derives from the inability of identity thinking to recognize significant differences between an exemplar of a concept and its norm, or from the systematic distortion of experience and self-constitution shaped by a phallogocentric symbolic order, or from spectacular redirection of desire away from use and toward illusion, the consequences are suffering.

These differing accounts all problematize the existence of suffering as an artificial and avoidable consequence of the dystopian way of life, theorize its increase and its assumption of specific forms in contemporary society, and recognize the need to orient ethical life towards the transformative negation of suffering. Their dire dystopian diagnoses respond to a condition of pervasive suffering imposed by the system that organizes the late modern way of life. The problem they see is not that happiness is impossible in the dystopian world. The more serious problem is that some happiness is possible, but only in a partial and compromised form, and one which requires ignoring or acquiescing to the suffering of others. This is the situation Adorno terms the "universal guilt context." Agamben sees in it the perpetuation of the infamous soccer game outside the crematoria of Auschwitz, described by Primo Levi. Pursuit of the compromised happiness available on dystopian terms actively blocks the approach to a transformed context in which dystopian suffering would be negated. Critical Assessments of These Dystopian Accounts These individual dystopian accounts, as well as the single account that could be constructed from them, are still not fully adequate to the symptoms of the contemporary dystopian situation. The refinements that are most needed lie with the treatment of the categories of gender and race, and with a more nuanced treatment of the dystopian problem of human cruelty. That assessment itself implies that the problem of class 
and the role of control of the means of production has been adequately treated by these accounts. In fact, each of these authors' dystopian assessments builds loosely on a Marxist chassis, and accepts the fundamental validity of a core class analysis. None, however, gives class division, or the structural position of the working class, the status of root oppression. On this point, their shared ability to see class dynamics and processes inflected by other variables, in particular (for Irigaray) the reality of sexual difference and its thematization in contemporary society, and (for Adorno and for Agamben) the operation of cultural-industrial or spectacular influences, is a mark of these theorists' perspicacity.

Their perspicacity also has its limits. Adorno and Agamben are, as we have seen, far from feminist. Adorno's language in Minima Moralia, for instance, has been analyzed as displaying a treatment of women, and working class women in particular, as primarily objects of possible enjoyment for men. ${ }^{4}$ His relatively simple use of the concept of "nature," commonplace within the tradition he critiques, but also a problem with that tradition, signals the limitation of Adorno's views. This limitation underscores one of Adorno's own insights, namely the deep conditioning of knowledge by its circumstances. To be fair, however, Adorno and Horkeheimer are also capable of recognizing the patriarchal character of the tradition they criticize. ${ }^{5}$ Agamben does not rise to this standard. Agamben's uncritical incorporation of Benjamin's romanticist treatment of woman, nature, and the animal is one instance of his failure to address the issue of gender in his work. If not

4. Claudia Leeb, "Desires and Fears: Women, Class and Adorno." Theory and Event. 11:1 (February, 2008).

5. "The 'happy match' between human understanding and the nature of things that [Bacon] envisaged is a patriarchal one: the mind, conquering superstition, is to rule over disenchanted nature." Horkheimer and Adorno, Dialectic of Enlightenment, 2 . 
feminist, however, Adorno's and Agamben's analyses lend themselves to critical feminist readings, and leave open significant possibilities for explicitly feminist extensions. ${ }^{6}$

Irigaray's relationship to feminist analysis is more complex. Eeminist theorists have been among Irigaray's most outspoken critics, based on understandings of her early work that read it as grounded in a traditional and essentialist treatment of the female body, and of some of her later work that blanch at her advocacy of sexuately-specific civil rights. Sympathetic readers of Irigaray, however, find her treatment of excluded differences fruitful for the development of ethical political models that extend beyond identity politics to suggest ways of appreciating whatever form of difference is most vulnerable to exclusion in the relevant political context.?

These readings of Irigaray also constitute one answer to the objection that none of these theorists deals explicitly or emphatically with the problem of race, at least not in the sense in which race has come to be a problem for analysis and for dystopian concern in the United States. Adorno and Agamben do discuss race in the context of the status of Jewishness vis-à-vis European nationalities, its salience in Nazi Germany, and racism in the form of anti-Semitism. Irigaray does not address herself explicitly to racial matters at all, despite her increasing emphasis on questions of multi-cultural communication in her later work, in particular Sharing the World. Implicitly, she makes sexual difference a model for all other forms of difference. This model does not address itself to the specifics of any national case, or to the way gender is taken up and intersected by and made to intersect

6. See Ziarek, "Feminine 'I can""; Lee, ibid.; Patrice Haynes, "To rescue means to love things': Adorno and the Re-enchantment of Bodies." Critical Quarterly 47:3 64-78.

7. Chanter, ibid.; Deutscher, Politics of Impossible Difference; Ziarek, Ethics of Dissensus. 
with race and class. None of these dystopian accounts are fully, concretely adequate to the problems of a dystopian situation characterized by racial division, inequality and oppression. Again, arguably, the challenge to scholarship is to extend the relevant lines of analysis to the most relevant forms of exclusion. Where race matters as much as it does in the US, an illuminating critique of the operation of racial ideology in exclusionary, spectacular society is necessary. ${ }^{8}$

The dystopian problem of human cruelty seems less amenable to critical repair. None of these accounts offers a convincing account of its genesis, or an approach to its resolution. Adorno comes closest in his analysis of the hatred of weakness in Dialectic of Enlightenment and of rage as ideology in Negative Dialectics. ${ }^{9}$ Agamben's treatment of evil as "the decision to remain in a deficit of existence" and to suppress constitutive potentiality as a fault falls far short. ${ }^{10}$ That Adorno and Agamben take the dystopian problem of human cruelty seriously, however, is indicated by their explicit engagement with the phenomenon of the Nazi death camps. That trauma establishes the stringency of the demands a promising response to the recurrent phenomenon of human cruelty must meet. If, in the end, they fail to make cruelty inconceivable outside the dystopian situation, it is not for want of their recognition of the problem.

Irigaray's omission here is correspondingly unsatisfying. Her utopian scenarios are promising and persuasive only to the extent that mutual cooperation and communication, unmarred by cruelty or motives

8. With respect to Irigaray in particular, Patricia Huntington's critical appraisal of Irigaray's textual practices and Ewa Ziarek's appreciative reading of Irigaray's "labor of the negative" converge in the direction of an ethical attitude of asymmetrical reciprocity and persistent dissensus substantially informed by Irigaray's insights. Huntington, ibid.; Ziarek, Ethics of Dissensus.

9. Horkheimer and Adorno, Dialectic of Enlightenment, 88-89; Adorno, Negative Dialectics, 349.

10. Agamben, Coming Community, 44 . 
towards domination, is an imaginable alternative reality. She offers nothing, however, in the way of a propaedeutic against cruelty. That she also simply fails to engage the phenomenon of the death camps may be significant. It suggests that, despite her respect for the death drives, she may place unwarranted confidence in a paradigm of original good will than is consistent with historical and sociological realism. The problem is illustrated acutely in her own work by her reappropriation of Christian symbolism and the language of redemption. Her use of this language ignores the problems associated with the way Christian narratives have served in western history as supports for domination. Irigaray also avoids developing an analysis of violence against women, one direction in which the focus on sexual difference might reach to an analysis of forms of cruelty and violence, and the threats they pose to utopia.

Developing a critique and assessment of the role of violence from an Irigarayan perspective on the foreclosure of the feminine or womanas-subject, along with its conflation with nature and the unconscious, would be both interesting and helpful. One line of development here could be to focus on the obliteration of subjectivity effected by the structure and organization of the camp, which would bring Irigaray's analysis close to that of Agamben. To this could be added Irigaray's distinctive recognition that the potential subject's development of her own subjectivity is necessary for her minimal well-being, such that this initial effacement itself constitutes a first cruelty, and a precondition for all subsequent cruelties.

An Irigarayan analysis of violence, however, would not resolve the threat to utopian imagination posed by the problem of human cruelty, especially in its traumatic late- $20^{\text {th }}$ century forms. That threat is the peculiar asymmetry that lies between the dystopian assessment, which 
demonstrates the existence of systemic cruelties as well as systemic inducements to extraordinary and idiosyncratic acts of cruelty, and any utopian possibility. Whatever utopian possibility might be thought seems to be without the protection of powerful interests, and vulnerable to the wanton exercise of power. These theorists, in the end, address a subject of utopian possibility who lacks even the illusion of shelter from the eruption of dystopian cruelty.

\section{Common Calls for Disruption and Resistance}

The critique advanced by each of these thinkers encourages critical readerly engagement as a response to the immediate dystopian situation. Each of their dystopian assessments asserts that something is deeply wrong with the way of life the reader shares with the writer. The first thing that has to change is what people do automatically without thinking about it. The situation demands disruption of and resistance to the dystopian context.

Drawing on an observation by Walter Benjamin, this change could be characterized as an "architectural" project. ${ }^{11}$ Benjamin claims that people absorb architecture, and the lessons of architecture, in a state of distraction. That claim is particularly suggestive when architecture is taken as a metaphor for the mind, the habitation of the human spirit. ${ }^{12}$ People absorb the lessons of their spiritual architecture in a state of distraction as well, accepting the form of life to which they are educated. Often they do so without stopping to orient themselves, or to ask whether what they are doing is what they want to or should be doing. Habitual patterns of thought influence and reinforce habitual patterns of action, and shape the quest for truth. This large, rigid complex must be disrupted so that it can be called into question,

11. Benjamin, "The Work of Art in the Age of Mechanical Reproduction."

12. See also Alain de Botton, The Architecture of Happiness (New York: Vintage International, 2008). 
resisted, and changed. These texts all advocate this response; they all function disruptively and critically, by calling attention to the contradictions of accepted wisdom and condemning easy acquiescence in comfortable routines.

Texts with this shared critical orientation lead their readers to anticipate programmatic recommendations. These texts, along with prophetic denunciations and political manifestoes, two genres which fulfill their form by enunciating specific behavioral prescriptions, participate in a radical rhetorical tradition. The texts studied here, however, deny their readers the closure of prescriptions for change. The absence of programmatic recommendations in the works of these authors may have been more acutely missed by their readers to the extent that their association with radical rhetoric raises this expectation. That absence may be one more reason why these authors have sometimes been labeled "utopian" in the pejorative sense. In fact, however, the absence of programmatic recommendations should suggest to the reader that the task of constructing adequate concrete responses to the situations described by these authors will not be simple or easy; its demands exceed the possibilities open to the texts that place it on the agenda.

The form of these authors' texts participates in the resistance and disruption they advocate. The hermeneutical operation of understanding these texts inaugurates a transformative process. The subject position of having read and begun to understand these texts is already a transformed subject position, and is to a degree already distanced from the situation the texts critique. The act of reading these texts, and struggling to understand them, effects this distancing of the reader from the object of the text's critique. In Agamben's terms, the subject who has read the text does not fully coincide with the subject who has 
not yet read it. The act of reading effects a determinate, even if slight, change in consciousness. Even if the reader rejects the texts' analyses, and does not go on to cultivate a differently motivated form of subjectivity, a dent or chink in the smooth armor of the spectacle, or of phallogocentric patriarchy, or of the fully administered society, remains.

The transformative impact of these texts resides in the reasons they are notoriously difficult to understand. Their difficulty is an intentional part of their project. Accessible texts do not disrupt established patterns of reading and understanding. Disruptive texts, which do, are less accessible. When Judith Butler, another formally dissident writer, argued this point she cited Adorno's Minima Moralia, which advanced the same position in the 1940s, as her authority. ${ }^{13}$ Irigaray has also taken the same position explicitly. Agamben takes the position more implicitly, perhaps most notably in The Idea of Prose.

These texts are not difficult simply for the sake of difficulty. Their inaccessibility is specific to their strategies. Adorno's arachnid weavings embody a dialectical mentality that circles the central point. His writing amounts to dialectics in action, mediation, or "unweaving." That is, the text encourages or exhorts the reader to look at a topic from multiple angles and to perceive non-identity or difference. Adorno's commentators have identified this form as one of the keys to understanding of Adorno's Aesthetic Theory in particular. ${ }^{14}$ The work is best conceived as intellectual motion around an idea, conducting a painstaking comparison of features, gauging the extent to which this or that property characterizes a phenomenon, noting where and how generalizations fall short, a method which according to Adorno

13. Judith Butler, A 'Bad Writer' Bites Back. New York Times. March 20, 1999.

14. Bernstein, ibid.; Finlayson, "Work of Art and the Promise of Happiness"; Hullot-Kentor, Introduction to Aesthetic Theory. 
gives the best knowledge of the truth, and the falsehood, that lies buried in an idea. The difficulty of the procedure is measured by its distance from a text that lays out its conclusions in a linear, systematic way. Such a text purports to fit its material, when in fact such a form can only be imposed on the material, disregarding that material's specific contours.

Irigaray's mimetic texts, according to whitford, provide a way to incorporate, as well as critique, the philosophers with whom she is in dialogue. ${ }^{15}$ Her challenge, of getting at the substantive presence of something typically seen as absence and lack, or nonexistence, is extreme. Irigaray's vision is, if correct, debarred; according to her, it is impossible to articulate directly in existing language. While Irigaray's readers sometimes long for her to "just say it," she cannot. Moreover, even if she could, and did, such direct expression would fall short of its purpose. Her goal is to evoke the recognition, and the objective context for symbolization, of ideas that have systematically been denied expression. The ideas, then, are not already in her readers vocabulary or repertoire. They cannot simply be referred to. Instead, they have to be generated, caused to emerge from the reader's engagement with the text.

Agamben's indirect and significantly negative non-arguments require the reader to struggle to fill in the blanks. His texts are open rather than closed. They meander through fields of suggestive prose rather than arrive swiftly at a predetermined argumentative point. They slow the reader down with deliberate digression or circumlocution, which is clearly neither merely decorative nor dispensable. Consistent with Agamben's persistent concern with potentiality, the absence of a single

15. Whitford, ibid., 71-72. 
governing imperative comes through these texts, perhaps discomfiting readers.

Every text, even a conventional one, has some potential to alter its readers. These writers' texts, it is claimed, are substantially transformative, and accomplish their effects with additional intensity. Because these are disruptive texts, they work against accustomed methods of understanding. They do not esteem logic as usual, though they arguably employ logic. They call accustomed methods of argument into question, challenging those methods' contribution to rigid thinking. Whatever understanding of these texts the reader gains can be gained only at the price of an adoption of their alternative logic and rhetoric. The act of understanding them entails seeing the point of view of the text, or at least adopting a point of view closer to that of the text's. Since that point of view is catastrophic, it is difficult for a reader to remain unmoved. In each case, then, the struggle and engagement with the text disrupts and effects a transformation in the reader.

The disruptive effect at which these different texts aim, moreover, is a substantially similar one. That effect includes an awareness of the limits of language, and the reader's own entanglement in what exceeds those limits. This transformative effect depends on readers' refusal to give up on these texts when their difficulties are encountered. Nothing guarantees this engaged response. Texts are passive, not coercive, however much readers of these texts sometimes report feeling oppressed. They reach only as far as the willingness of their audience. For that reason, the actual "interventions" texts of this sort can effect are restricted in advance. While the effectiveness of the utopian discourse undertaken in these texts has not been a primary issue for this study, the question of what will become of these 
ideas does assert itself. The ultimate impact of this form of utopian discourse may depend on whether it can sustain itself in some form beyond the narrow boundaries of the texts in which it has been developed.

\section{A Shared Critique of Language}

A critique of language shared by these writers plays a role in the disruptive impact of their texts. To a large extent, contemporary linguistic theory operates with a sign theory of language. Words are more or less arbitrary signs, attached by convention and perhaps history to concepts that are adjustible and re-specifiable. Since Saussurian linguistics, their meanings are understood to reside in the conventionally-established system of differences between one sign and another. The idea that there might be a "true" or "just" expression of an idea, or that there might be more than an arbitrary connection between the physical housing of an idea, its word or name, and the idea the word signifies, is difficult to take seriously. These authors do not fully share this view, familiar to contemporary readers. Readers who approach their texts with the sign-language view commonplace today will encounter difficulties understanding them.

Instead, words or names for these authors retain an intimate connection with personal experience and extra-conceptual reality. Words are more than empty signs, and meaning is more than a system of differences, although the value of the insight that meaning depends to some degree on such a system is not lost on Agamben and Irigaray. Words also have positive contents. Words and their contents are affected by the way their users use them. Words also have a physical presence, which works with or against their conceptual function. They are themselves things, and as things they have something like a life of their own. These authors share an appreciation for the raw material of 
language, its "body" or "silva," that sets their reflections on

language, presentation, and communication apart from other contemporary thinkers. ${ }^{16}$

The linguistic insight here seems to go back to the denominative function of language, and in particular to notions of "enchantment." A recognition of the potentially enchanted quality of language is consistent with an approach to the world that would not be intent on domination. Enchanted language is no longer the language of science. Rather, it seems to be a more original language of things, something approaching a language of nature, which would of necessity also be a language human beings, who continue to embody nature, could share.

The form this respect for the materiality of language takes differs from author to author. Adorno is explicitly careful about the use of words that have, by virtue of their history, content that can no longer be used to communicate the ideas that need to be discussed. This care informs his gesture of reaching back into the past of aesthetic theory to resuscitate Kantian terminology to accomplish his purpose in Aesthetic. Theory. Agamben pays more explicit attention to the distinction between body and spirit that is embodied in language itself, although this distinction is noted by Adorno as well. Both Adorno and Agamben, in fact, echo the notion that ideal language would correspond to things in themselves, a picture of ideal language they both derive from Walter Benjamin's image of Adamic language.

Irigaray seems to share a similar understanding, since in The Way of Love she paints a picture of new language that would proceed from the self-experience of the sexually different subject, and would reflect this experience. This new language would be able to communicate sufficiently without a pre-established meaning; this implies that it

16. Adorno, Negative Dialectics, 56; Agamben, Idea of Prose, 37. 
can convey something intelligible outside of its participation in a pre-developed system of differences. Instead, Irigaray's new words must have manifestly variable content, since they cannot be taken always to mean "the same thing," but have a mobile relationship to the experience of their users. They cannot, then, function as conventional signs; they do not exchange information; they are, rather, vehicles for communion.

All these authors thus suggest that renewed attention to language, along with new practices with respect to language, play a role in the reconstitution of subjects, or subjectivities, of utopian possibility. Where language is a vehicle for the sharing of experience, as distinct from the exchange of information, an adoption of a changed relationship to language becomes part of the cultivation of an alternative subjectivity encouraged by these texts. What this would mean might be suggested by certain fugitive experiences with language in which many people share, at least from time to time: in participating in children's acquisition of language, in occasional intimate negotiations over the meaning of a word or phrase, or in the spontaneous invention of metaphor. Indeed, this understanding of language substantiates Irigaray's claim that what is needed for the complete thinking-through of the meaning of sexual difference is a "new poetics," since this understanding of language takes the matter of language, which furnishes the possibility of poetry, as having a more general significance.

A Subject Capable of Transformation

We have seen that each of these theorists places a significant emphasis on a renewed understanding of the subject of knowledge and action, and its relation to its object or objects. A central common feature of this subject is that she is - or could, and ought to be actively "under construction." This feature of autopoietic human subjectivity provides one of the core conditions for the development of 
a subject of utopian possibility, although as Adorno notes, it is also the source of the persistent problem of dystopian distortion.

For Adorno, the subject is always already constituted by the forces of society and history, nature (inner and outer), and culture, as well as by the operation of reason. The exercise of reason, which contributes to the development of the subject as separated-from its object, and which is called upon to resist the forces of unreason, is not historically innocent. It has also contributed to the domination of a nature in which humanity itself is thoroughly enmeshed. A relentless question for Adorno is whether this conditioned subject can realize any independence from the circumstances which construct it, or whether its perceptions are entirely prescribed by its history and circumstances. This concern explains his insistence on the method of negative dialectics, which confronts the concepts through which things are known and through which the knowing subject comes into being with contradictory signs and indications. The tenacious refusal to ignore even the microscopic differences between things as conceptualized and things as they present themselves to experiential encounter preserves the possibility for influences "external" to the system devised by a subject bent on domination. The method of negative dialectics offers a slim hope for a subjective solidarity with the concrete, and for the fashioning of perspectives that "displace and estrange the world" in a prefiguration of "messianic light."17

Irigaray devotes much of her textual effort to laying out conditions for the development of woman-as-subject. Woman as subject appears in her work as the creation of a complex process requiring communication across the lines of sexual difference, communication within the boundaries established by sexual difference across other 17. Adorno, Minima Moralia, 247. 
lines of difference, and processes of "return to self." Return to self entails the development of "auto-affection," self-influence or selfconstruction. Her treatment, as we saw, seems to require critical, iterative reflection and possibly group process. ${ }^{18}$ Key to understanding all of these different bodies of work is the recognition that the woman-as-subject occupies the position of a messianic figure. Perhaps more precisely, woman-as-subject is a quasi-messianic figure. That is, woman-as-subject does not accomplish the work of the traditional messiah of messianic religions, ushering in an age that fully redeems past history. The advent of woman-as-subject does, however, announce the beginning of a new relationship of humanity to nature. She ushers in the objective conditions for cultivation of a new form of culture that recognizes human nature for the first historical time, and permits the construction of a new form of politics and ethics. This collective life is now based on the distinctive, and no longer repressed, needs of the fully human and always not fully "representative", that is incomplete in themselves, subjects of sexual difference. The cultivation of this subjectivity itself provides the avenue for the cultivation of a more adequate utopian vision.

Agamben sets out again and again to come to terms with a subject which is constitutionally uncalled for, lacking a determinate or determining "nature" or purpose. His reflections on potentiality, and its relationship to a community of "whatever being" that is purposely conceived independently of specific identifications or criteria for belonging, recognize and require a self-constituting subject capable of far greater freedom than it may yet realize. The specific potential subjects of the coming community, for whom each particular predicate

18. How much group process seems to depend upon how we think about autoaffection. 
"always matters," can only become what they are through their practice of ethics and politics. If they have an urgent task at present, it is the development of a form of life inseparable from life itself. Agamben's self-constitutive subject remains in a position to choose which practices to engage in and which directions to pursue. This inexhaustible potential is consistent with the radical break Agamben associates with an authentically "messianic" community.

In each case, then, the current subject of dystopia is identified as the site for the recognition and innervation of a subject of utopian possibility. The subject of possibility, in turn, becomes the threshold for messianic or utopian transformation. These texts leave open the question of whether the subject under construction is an individual conscious human subject, a "psychological subject," or a collective and communal one. Presumably the transformation of even a small area of society calls for the development of a collective subject. The psychological subject, which is the subject of suffering most people care deeply about, however, remains stubbornly singular. Ultimately, a promising subject of utopian possibility probably needs to be conceivable on both of these levels.

What the subject clearly is not for these thinkers, however, is that transcendental subject of being, knowledge, and reason familiar from its autobiographical reflections in the history of western philosophy. The delusions of that subject are part of the problem for these authors. Part of the solution is a concrete subject of possibility, one who both transcends and is transcended by a material reality which urges it in the direction of utopian transformation.

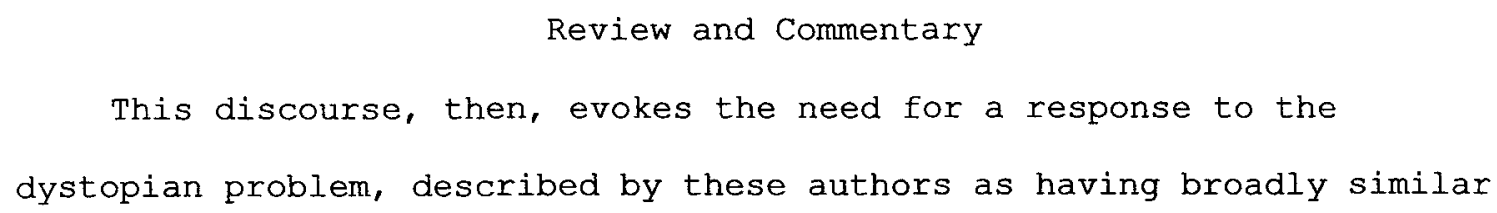


features, and in particular the feature of excluding or invalidating forms of consciousness that would pose utopian alternatives to the prevailing situation. It sketches and enacts a possible response of discursive disruption of and resistance to this dystopian. It thereby asserts the inadequacy of conventional language to the task of communicating a utopian alternative, and evokes a repertoire of corrective possibilities. In so doing, it begins to construct the desire for, the idea of, and the discursive reality of a subject of utopian possibility. Such a subject of possibility differs from the ideal subject cultivated in and by the dystopian situation.

Margaret Whitford has noted that Luce Irigaray's work combines a "critical moment" with an indispensable "utopian moment."19 Her comment could be extended to the work of Adorno and Agamben as well, even though Adorno and Agamben develop the utopian moment less fully than does Irigaray. ${ }^{20}$ Whitford's insight identifies a feature that allows this utopian discourse to create a compelling dynamic interaction between texts and reader. The texts address themselves to the subject of a dire present situation, which urgently demands transformation, and whose condition the text shares. The chances of transformation are small. The text offers no grounds for hope for any built-in tendencies towards transformation. It does, however, offer its repertoire of disruptive and resistant perceptions, positions and practices, which the reader is encouraged to appropriate insofar as she adopts the perspective of the text, seeing the danger and agreeing that the danger is real. In so doing, additional self-creative dynamics - that is, dynamics that create a self - are brought into play which could,

19. Whitford, ibid., 135-136.

20. As noted earlier, this discrepancy stems directly from Irigaray's identification of the foreclosure of the development of woman-as-subject, and the need to challenge the phallogocentric structure of language itself, as the central focus of her critical and transformative work. 
however slightly, destabilize the dystopian situation. Where the dynamics of the dystopian situation work to make the present appear as a universal, rational, and unquestionable set of givens for human life, these counter-dynamics challenge the system's pretensions. The subject of such counter-dynamics experiences the imperative of thinking an alternative to the dystopian situation. In so doing, that subject is always already participating in becoming a subject of possibility.

There is a negative aspect to this self-creative practice. These self-created subjects of possibility likely will experience a heightened and more acute discontent within the dystopian situation. Subjects who are better adjusted to that situation presumably have a different experience, more contented if not necessarily happier. Heeding the call of utopian discourse may actually increase unhappiness, and whether or not that unhappiness will be repaid by subsequent personal happiness, or will even prove to have been in the service of happiness of any kind, is uncertain. The subjectivity of utopian possibility is for this reason, ironically, an alienated one that is deeply disturbed by its own dystopian location. But its characteristic dissatisfaction stems from its intuition of a form of happiness not accessible to the undisturbed subject of dystopia.

It remains to show how this subject of possibility, as it takes shape in space and time, constitutes a promising site from which to imagine, and perhaps to pursue, that negation of suffering for which one name is utopia. The reason for this promise has to do with the conjunction of the discursively constructed subject of possibility with the subject matter of suffering. That conjunction involves the participation of space and time in the formation of the subject of possibility. 


\section{The Chronotopic Subject of Possibility}

Human subjects, singular or collective, are in a root sense "made of time." They are not only made of time, however. In these discourses time merges with the space that human subjects also are, to effect the particular kind of space required for the imaginative projection of utopia. This recalls Bakhtin's concept of the chronotope. For Bakhtin, a chronotope is a four-dimensional concept that solidifies time spatially, or that expands space temporally. Space and time become interchangeable, or exchange characteristic properties. Examples given by Bakhtin include the "encounter time" of the "threshold," or the "adventure time" of the homogeneously exotic world of the Greek adventure novel. ${ }^{21}$ Utopia itself, as noted earlier, is chronotopic, uniting a not-now with a not-here.

For these authors, the time that makes up the subject of possibility also constitutes the opening-up of a threshold for utopian space. More precisely, the possibility that gives rise to this subject erupts as potentially utopian space, within the dense and unmappable space of late capitalism, from an "outside" that has not been fully captured in that system. It remains "outside" because it has been specifically excluded or foreclosed by the system: Adorno's nonidentity, Irigaray's "woman," Agamben's "bare life." The time lived by the self-created subject of utopian possibility constitutes space cleared for what as yet has no recognized place. This u-topic space is not an actual existential phenomenon. It comes into being as something inserted from without, in the act of making visible and meaningful the differences between official reality and an alternative in which the suffering imposed under that official reality would be negated by its transformation into happiness.

21. Bakhtin, "Forms of Time and Chronotope in the Novel," 87, 248. 
Arguably, then, the subject of possibility constitutes a strategically important space-time within a dense form of life which represents itself ideologically as a totality without alternative. That dense form of life, whether conceptualized as late capitalism, the society of the spectacle, or phallogocentric discourse, is inimical to the cultivation of utopian possibility precisely because of its objectively pervasive scope and its persuasive characterization of choices that disrupt or resist its operation as futile, objectively irrational, or ultimately inconceivable. The space-time of the subject of possibility is physical space and temporal consciousness in which to cultivate the initially minute discrepancies that belie the absence of an alternative to the existing order. These include the non-identity between death and reconciliation, the difference between the prevailing concept of "woman" and what "woman-as-subject" might incorporate, and the non-coincidence between a community erected around some determinate identity and a community of whatever-being. The discernment of those gaps or discrepancies is itself a sign of the critical taking-place of a micrological non-dystopian possibility. That possibility is the vehicle for the characteristic mode of influence of the "messianic light" named in this utopian discourse.

The Event of an Outside as Potentially Utopian Space

The subject of utopian possibility depends upon the credible event of an outside. The subject's relationship to this event varies from writer to writer.

Adorno does not envision the subject of possibility as being situated outside, but as being attuned to or with something like an outside and able to discern its traces through the operation of dialectical reflection. In effect, the thinking subject, in the practice of a consistently negative dialectics, is able to formalize 
the negation of suffering implicit in aesthetic expressions of suffering and artistic efforts at its transformation. The flesh and blood philosopher can reflectively connect these formal negations to grateful memories of happiness that constitute the material base of something like metaphysical experience. This prismatic thought struggles to separate the genuine flickers of happiness, which bear witness to a persistent "undisfigured" concrete, from ideological resignation to dystopian existence or pleasure taken in its prescribed exercises of domination. Adorno's subject perceives, communicates with and mediates the possibility of an "outside" to the dystopian context indirectly, reflectively and cautiously, suspicious of that subject's own indiscernible inner distortions.

For Agamben and Irigaray, the subject of possibility incorporates or is the threshold for the event of an outside. Irigaray's lengthy discussions of the sexually different subject's construction of a separate dwelling, which she furnishes with a threshold, and orients towards a space of encounter from which a return to self has already been secured, speak to the intentional cultivation of a subjectivity for which the preconditions already exist. Agamben focuses attention on the pure event of an outside most explicitly in the Coming Community, in his discussion of the relationship of singularity to the whateverquality of whatever being. For Agamben, in explicit contrast to Adorno, the singular subject of thought and experience always has available to it, by virtue of its exemplarity of whatever being, the ecstasy of "the experience of being-within an outside." 22

In each case, however, the extra-dystopian outside in question shares important features. It occupies a realm that is concretely material. For Adorno, it embraces the discernibly extra-conceptual core

22. Agamben, Coming Community, 68 . 
of every concept and the mute, uncomprehending witness of the object of aesthetics. For Irigaray it is the source of the centuries-long conflation of "woman" with "nature" and "matter." For Agamben, it is the substrate that makes possible the characteristic exclusion of an inclusion, or inclusion of an exclusion, that structures the various states of exception that haunt the communal structures of western culture.

As may already be clear, this concrete realm bears the relationship of an "outside" to the dystopian context precisely because of its exclusion and inadequate thematization within that context. On one hand, this exclusion and inadequate thematization is just what makes the dystopian context dystopic. On the other, however, it is what permits the concrete to appear as the "undisfigured" and corrective alternative to that context, rather than as one of its thoroughly conditioned prefabricated elements.

Finally, chief among the contents of this outside is the concrete matter of suffering. The outside includes the insistent registration of emptiness that belies the spectacular representation of reality as characterized by plenty, the sensed muscular tension or chronic inflammation that asserts the nonidentity of human fulfillment and "having a good job," the fatigue that is beyond speech, and every other concrete indicator of not-yet-negated suffering. As such, it constitutes the raw material of utopia, insofar as utopia is suffering, in the form of its negation as happiness.

This discourse, then, evokes its subject of utopian possibility as the observer or threshold of an eruptive event of an outside. The grasping of this outside, or rather its potential, occurs in time. But the pregnant symbol for the kind of eruption of a transformative outside is that of a messianic event. The time that the subject of 
possibility makes and lives out of this potentially utopian space is messianic time.

The Auto-Poietic Subject of Possibility as Messianic Time The time that emerges in these thinkers' works is explicitly "messianic" in their terms. Irigaray's use of the annunciation as a figure for the communication across lines of sexual difference she envisions indicates an appropriation of available messianic symbols for a new use. Agamben's time that remains is once again explicitly focused on a kind of messianic expectation. Adorno remains agnostic on this point, referring instead to the wish for a divine redemption, which while unacceptable indicates for him the limit of the desired and desirable utopia.

Agamben's analysis of the poetic structure of the outside, and its associated subjectivity, is probably most illuminating. Poetry, philologically speaking, is the activity of making something from nothing. It is, in essence, what the practice of humanity entails. The ethical and political practice of humanity is formally poetic. This follows from the identification of humanity as an intrinsically empty condition, one without a work that gives humanity an imperative set of practices or behaviors. The practice of humanity, of human life, entails ethical and political choices because of its poetic character.

For Agamben, the definition of poetry further entails the recognition of the divergence or potential divergence of physical form and human (cultural, linguistic) meaning. The possibility of enjambment calls attention to this always-at-least-potential divergence.

Enjambment registers and renders discernible the non-coincidence of the material features of poetic language, the features of sound embodied in rhyme and of touch embodied in meter, with its less material features of meaning by way of denotation, connotation, implication, association. 
In prose there is no corresponding possibility of enjambment, which does not necessarily mean that there is no divergence, but rather it may mean that there is no possibility of its recognition. A prosaic situation could be one in which the physical form is entirely plastic, or the human meaning is entirely transparent, or it could be one in which the potential divergence and source of creative tension between the two has been fully suppressed, rendered imperceptible.

Dwelling prosaically, then, may be a figure for dystopian existence. Dwelling poetically may be an alternative figure for messianic anticipation, in which attending to and bearing witness to this noncoincidence of elements, within language and within ourselves, is a way of mobilizing the inexhaustible potential incorporated in humanity. Agamben's analysis of the Pauline messianic message further emphasizes his perception of the active accessibility of messianic time, which is consistent with the notion of the self-creation of the messianic subjects. The subjects of the messianic event have, first of all, to be those who cultivate messianic anticipation, and who prepare themselves for participation in the messianic moment. These subjects create differences, first of all within themselves, which in turn make a difference in practical living.

The messianism these authors share is not the messianism of the messianic religious traditions, or even the messianism of artists who have the idea that art can single-handedly change the world. However, it is compatible with the structure of an influence that is awaited and prepared, an influence that breaks in from outside, or that erupts from within the structures of immanence. In all this work there is the conviction that within this context of immanence forces are present, available, and still accessible that have the potential to transform this dystopian context into something else. A different way of life 
remains possible, although saying so directly and simply would constitute an illegitimate reassurance offered to the dystopian context, in which that simple statement remains, in many important respects, false.

The essence of messianic symbolism and language for these authors is the way relation to it constitutes resistance, and breeds further resistance. Even for Adorno, whom Agamben decries as absolutely unmessianic, there is more resistance going on than at first meets the eye. It is the vital resistance of renaming, puncturing "identity." For Irigaray, the effort to articulate different temporalities across the line of sexual difference emerges as a messianic task. Agamben, as we have seen, sees the enactment of messianic anticipation as an everpresent potential. For Agamben, the ideal, exemplified in the Pauline kerygma, is an announcement which enacts itself and constitutes itself as the good announced. In any case, however, messianic resistance is a refusal of premature announcements of salvation, and of non-messianic faith, that is, faith in anything that is not yet the advent of the messianic time.

\section{Minimal Material Metaphysics}

This discourse asserts itself as utopian in its struggle to sustain solidarity with something like metaphysics. Its success in this struggle is, in fact, indispensable. Utopian thinking depends upon a source of metaphysical ideas, upon a credible unknown outside. That metaphysical reality also has to be communicable. It has to have one or more points of contiguity, shared reality, with what is to be transformed.

The theories of an event of an outside developed across this discourse might be called minimally metaphysical. They are an effort to respect the constraints of the critiques of metaphysics, and to avoid 
something that cannot be credible, while preserving the difference from the current context that is a prerequisite for utopian thought and discourse. "This," whatever "this" is, cannot be everything. "What is must be changeable, lest it be all."23

Philosophy is serious, but then again, it is not all that serious, as Adorno noted. Other things matter more; some people's real suffering, for instance. The practical question of how to go about pursuing the elimination of suffering, while remaining in and cultivating solidarity with those who face and undergo suffering, is ultimately central, and remains central to the basic enterprise of utopian thinking. That practical question becomes a serious philosophical question to the extent that the philosophy involved in historically earlier efforts to solve that problem have imposed additional suffering, and blocked efforts to relieve suffering. These philosophers contend that it has. The solution to the question of what the negation of suffering would look like and feel like - the utopian solution - cannot take the form of the domination of nature sketched out in Bacon's New Atlantis - or, according to Irigaray and Agamben, even earlier: in Plato's Cave and Aristotle's polis.

These thinkers pursue the possibility of metaphysical thinking in a post-metaphysical age. They respect the impossibility of any "future," or traditional, metaphysics. But they also seek to secure for the benefit of the subjects of dystopia the good that metaphysics once seemed to secure, namely the potential for an effective form of utopian imagination.

We are not the subjects of utopia. We are not even, yet, the subjects of utopian striving. Utopian images that would motivate us would be manifestly unjust and would fail to represent adequately the

23. Adorno, Negative Dialectics, 398 . 
utopian condition that might be achievable from here. But as cosubjects of dystopia, along with these authors, their readers are well situated to undertake the practices that bring subjects of possibility into being.

\section{A Preliminary, Transformative Mode of Utopian Discourse}

The effort to construct the subject of utopian possibility is the genuinely "weak messianic" task, or rather practice, of our day. Its transformative discourse links utopia with art and religion, which are similarly practical, transformative, and regulated by ideals. That is, these enterprises take place through practice; they operate to transform their specific materials; and they orient their transformative practices towards a criterion related to an understanding of the good. Insofar as the point of contact between religion and art lies in the orientation of these two different bodies of practice towards the transformation of material life, the transformative practice associated with the subject of utopian possibility, which takes place at the point of intersection and imagination of a renewed poeisis and a reimagined completion of human life, aims at something both religious and artistic, though also other than either. This renewed practice is at the same time political (having to do with personal and communal decision, in particular about values; with what values will be put into practice, with the hierarchy of values) and ethical (having to do with the pursuit of the happy life). These cannot in the end be separated from one another, which is why under the aspect of a system in which the value spheres have been separated from one another they appear to deal with similar issues in isolation from one another.

The task of utopia ultimately remains that of the elimination of suffering. The effort to eliminate suffering by eliminating that which 
suffers - Nature-as-object, e.g., along with its designated human carriers - has been shown up as a dismal failure in the west. The task could still be pursued differently, in solidarity with that which suffers. This different pursuit of the negation of suffering will entail a new curriculum, based on the cultivation of a different kind of subject, the "weak messianic" subject of utopian practice, which is simply happiness as a way of life.

The subject of utopia is clearly not "the messiah" in a traditional religious sense, however much these authors make use of messianic language and messianic terminology in talking about him, her, or it. While Irigaray uses the language of parousia, Agamben talks about the construction of a messianic community, and Adorno draws out the messianic metaphor from time to time, the subject of utopia is not a magical figure to be awaited, while the active context of life plays out unresisted. A more general understanding of "messiah" as a figure designated for a redemptive task might fit the subject of possibility, rather loosely. The subject of possibility does incorporate that eruption of an outside into the space-time of the here and now, and does speak on behalf of someone or something: on behalf of suffering concrete material life.

The subject of possibility does not, however, usher in sweeping change, except perhaps in a micrological and preliminary way. In the process of searching for and remaining alert to traces of what lies beyond the dystopian context, in cultivating skepticism about the lack of alternatives to an ideological totality, in practicing fugitive forms of change, the subject of possibility undertakes a transformative discursive practice. This subjectivity may contribute most by refusing to relinquish its unreasonable demands for patently impossible results. 
It is customary to think of utopia as a particular form of representation. But the idea of utopia requires the idea of transformation. Even the representation of utopia is, as Fredric Jameson notes, something that purports to force people to "think the break." That is, it is a representation of a wish that pushes its readers to think the processes of transformation, and perhaps to engage in the practices of transformation that might feed in to the utopian condition. Even if those practices do not bring about utopia, they might at least render the present dystopian moment more like the utopia of the imagination. Utopia, utopian thinking, occurs in solidarity with reflection on what in the world needs to change, and on the conditions for its change, unfettered at least temporarily by the a priori dictates of what is reasonable within the givens of the moment. In practice this imagination is never as radical as it could be or needs to be. There are things that the imagination from the present cannot anticipate. The transformation of character that would be required to envision the real utopian change has never yet taken place. While it is possible to argue that the ultimate transformation of character does not take place until the advent of the utopia, it is equally true that the advent of the utopia can only be prepared by the cultivation of a new form of human life. This insight, which is one of the insights shared by the world's religions as well as by Aristotelian ethics, continually returns to the insight that the way forward is built on efforts in the present.

It is these potential efforts in the present, which cut against the grain of the present culture, which make demands that are impossible to fulfill, and which forego the complete happiness possible in the present for the sake of holding on to the vision of something that would be superior, that endow humanity in each generation with the 
"weak Messianic power" noted by Benjamin in the second thesis on history. The weak messianic power does not effect the redemption of the world. To the extent that it is made effective, however, it does change the world, and its responsibility both to the past and the future is to pursue a direction of change that heads towards the "messianic light" that would be shed upon things from the point of view of the longed-for redemption. This requires the cultivation of new people, such as Irigaray's woman-as-subject, who have never yet voiced their desires, because they have never yet appeared on the earth. When their voices are heard at last, they, too, will - as the voice of suffering - point in the direction of something like redemption.

Utopia in this discourse makes a particular quality of life together its ultimate aim, and projects less a form than a way of being. Transformative practice cannot proceed without a criterion or set of criteria for remaining true to the good or goods at which it aims. The criterion implicit in the utopian discourse considered here at last offers a candidate for the substance to the metaphor of "messianic light."

"Messianic Light" as Practical Criterion If "messianic light" is more than an empty metaphor, its content seems to be that of a criterion for the efforts of the subject of possibility. That criterion is not encoded in an image; one of the insights of this discourse, along with all "iconoclastic utopianism," is that imagistically encoded criteria for utopia become obsolete, and then lend themselves to oppressive appropriation. That criterion is also not encoded in a formal procedure, such as the use of reason. Indeed, this discourse makes its aim to demonstrate that the use of reason as the procedural criterion in western civilization has contributed to the specific dystopia facing that civilization today. 
Instead, the criterion is something that might be called, less metaphorically, the well-being of the subject matter. The animal body. Woman. Whatever being and its mute but expressive face. The criterion of messianic light is that the suffering people continue to care about is mitigated, not by suppression or repression or denial, but by transformation into happiness.

We would establish our understanding of it by reflection, according to Adorno. It would make itself felt in art, and philosophy as art's reflective partner would articulate the direction in which the negation of suffering would be available. We would experience it as radiation, according to Irigaray, the radiation of the formation of a subjectivity of its own, based on difference, but not reduced to symbolizing that difference, but cultivating its own content. We would carry it with us, halo-like, in the enfleshed faces of whatever linguistic being we would cultivate, and would bear witness to it more conscientiously, with greater awareness of our constitutive continuity with that material. In each case, messianic light is not unproblematically equivalent to an immersion in immanence, as if an unmediated knowledge of the utopian criterion were available. Nor is it an assertion that the desires and preferences accessible to our linguistically-shaped reflection or consciousness are in any way "pure" or perfectly reliable indicators of the direction of a utopian true north. Nevertheless, the premise is that there is a corrective already available. That corrective stubbornly perdures in the failures of this source of messianic light to conform to cultural expectations; its stubborn discrepancies from what is expected. In the way matter transcends spirit, remaining outside and beyond its dominating reach, insisting on revealing its true character and identity regardless of the names given it by spirit, the "metaphysical" possibility that makes possible utopian discourse 
persists, and stupidly and unreasonably insists on not being satisfied with something other than whatever constitutes its satisfaction. Developing the skills and the language necessary to pursue that satisfaction then becomes the task of the subject of possibility, a development which finds its orientation in what has been called here "messianic light."

Post Script: The Work of Messianic Lighting

Terminology

The words "jargon" and "argot" each refer to a specialized and generally unintelligible practice of language. "Argot" denotes the specialized vocabulary of any class or group, and has nuances of criminality or "the underworld." It is unintelligible, when it is, on purpose. Argot permits the members of a small gang or "coquille" to communicate with one another without tipping off the potential objects of their predatory actions. "Jargon" derives from a word which in old French denoted "a chattering," as of animals or birds. It now frequently refers to the specialized language of an occupational group, but retains its earlier meaning of unintelligible or confused - and for that reason, confusing - speech. Specialized professional language is both jargon and argot: jargon to outsiders who experience it as unintelligible and confusing, thexefore seemingly confused; argot to the cognoscenti.

Instances of specialized language have a strategic political and philosophical importance, according to Giorgio Agamben. ${ }^{24}$ They serve to break the romantic conflation of people, language, nation and state. Since the imaginary order that continues to structure global political life is based on this obscure conflation, and since finding ways to make this order inoperative is an urgent and important political and

24. Agamben, Means Without End, 63-70. 
philosophical task, jargon and argot should excite more than simply Iinguistic or literary interest. They embody issues of communicability, belonging, exclusion and presupposition that are enmeshed in the practice of language.

Jargon's relationship to a specialized form of life, such as an occupation, makes it a sociological phenomenon. The practice of an occupation and the use of its jargon synchronize practical lines of difference between practitioners and non-practitioners, and produce experiences of belonging and exclusion, communicability and incommunicability, presupposition and ignorance. Learning and using professional jargon or argot comes with occupational practice. At the same time, it constructs the learners and users as conscious and selfconscious participants in the roles for which the jargon or argot is the common parlance, while symmetrically constructing non-users of the jargon as outsiders or incompetents. ${ }^{25}$ It exemplifies the role of language in the fabrication of a specifically constituted subjectivity.

In the jargon or argot of the world of professional theatrical and photographic lighting, the words "grip" and "throw" have specific uses that differ from their more general associations with grasping by hand and hurling through the air, so as to produce a turning or twisting motion. ${ }^{26}$ In that specialized parlance, a "grip" is "the crew member who hangs lights, pushes dollies, hefts cases, and, on the West Coast, handles Reflectors." "Throw" is the "distance light travels from Source

25. Beth A. Bechky, "Gaffers, Gofers, and Grips: Role-Based Coordination in Temporary Organizations," Organization Science 17:1 (January-February, 2006) 321.

26. Both "grip" and "throw" derive from Old English, "grip" from gripe, grasp and gripa, handful, "throw" from thräwan, to turn, twist or curl. 
to Subject." In this special context, the "Source" is anything that produces light, while the "Subject" is whatever needs to be lighted. ${ }^{27}$

A "grip" is not a "gaffer."28 The province of the gaffer - also named the electrician, or "juicer" - extends to everything connected with or to the electrical power, or "juice," required to produce artificial light. "Gaffers and electricians make light; and key grips and grips control light."29 This division of technical labor explains why "exterior days" in a project schedule, for instance a film shoot, "are often called Grip Days, since usually a single massive nuclear lighting source is used instead of electrically powered lights." 30

Whatever the source of light, grips construct and place the apparatus of reflectors and diffusers that shape and direct its throw, to produce specific lighting effects. Ideally, these effects will be those desired by the projects' participants, and will also please important others, like producers or clients. In essence, grips are the crew members who handle the mechanics of the project that calls for professional lighting. The exigencies of these mechanics also give the key grip the final say on various matters of technical feasibility, like whether a camera can or cannot be placed - without excessive risk to life and limb - in a particular location. ${ }^{31}$

Grips, then, are neither the primary "Subject" of a lighting project, nor the generators or sources of the lighting for the project. They are, however, subjects whose involvement in matters of lighting

27. See Ross Lowell, Matters of Light and Depth: Creating memorable images for video, film and stills through lighting (New York: Lowel-Light Manufacturing, Inc., 1992); glossary online at http://www. lowel.com/glossary, May 1, 2010.

28. A "gaffer" is lexically "an old man," or in British English a "foreman" and an alternative to "godfather," a term with argotic connotations of its own.

29. Jeffrey M. Hamel, "Lighting vs. Illuminating," at http://www.studentfilmakers.com/news/printer 1610.shtml, accessed June 1, 2010. 30. Anonymous, "The Art of Grippage," online at http://everything2.com/user/fugdup/writeups/Grip, accessed June 1, 2010. 31. Bechky, 12 . 
can make the difference between satisfactory and unsatisfactory results. Their understanding of the results to be obtained, their grasp of their craft, and their creative ability to work with the elements of a situation and devise solutions to problems as they arise all play a role in the success or failure of the project. These subjects mediate the throw of light, without being either the lighted subject, or the light that lights it. Their work determines whether, for instance, the subject emerges as discernibly different from its surroundings, or recedes imperceptibly into their shadows.

The relationship of the grip, who mediates the throw of light, to the subject of a lighting project is in some ways analogous to the relationship of the subject of utopian possibility who has surfaced in the preceding chapters to the subject of utopia itself. One conclusion of this study is that the discourse of the three authors considered here speaks to a subject of utopian possibility, and works to bring that subject of possibility to awareness and possibly to action. This subject does not possess utopian subjectivity; being outside utopia, this subject can have neither an experience of utopia, nor a clear and precise sense of its contours - at least, not a positive one. Instead, the subject of utopian possibility is a subject who can form the stillabstract idea of utopia, take it seriously, and undertake to illuminate its possible contents. It is a subject capable of imagining an alternative to what presents itself as reality. If it is true, as Adorno claims, that perspectives must be found that permit "messianic light" to reach the dystopian scene, it is the subject of utopian possibility who will have to act as the grip.

Working with Available Light

All light is energetic matter. Light in the act of lighting up a leaf, or a face, is an example of matter affecting itself. This is no 
less true of messianic light. While the name "messianic light" suggests something that emanates from elsewhere, the light it casts is always already available. As the discourse considered here makes plain, messianic light comes from the material world.

The idea of messianic light is, finally, a tenaciously this-worldly idea. Not only is there no other world, it implies, another world is not what people really want. Utopia, perversely, is this very world with a little difference.

Presumably, this tiny messianic difference is what mobilizes, not impossible energies and alternatives, but ever-present ones that are temporarily blocked, ineffective. It appears to be akin to the thought of the impossible made possible, a reverse enchantment which frees the possibilities frozen in the situation. It works the way the name of stone soup works, to put perfectly ordinary soup into the mouths of the hungry and to make doing what was always perfectly possible an occasion for celebration. Stone soup, after all, differs from soup only by a word. But the word matters. It is stone soup whose name makes it seem inconceivable, and whose aura of impossibility is the condition for its possibility.

As the story goes, the little difference between dystopia and eutopia is so precise and fine, it awaits the coming of the messiah to make it. It remains to learn whether the weak messianic power with which our generation is said to be endowed could, or will, make as little difference as that. 
REFERENCES

Adorno, Theodor $W$. The Adorno Reader. Edited by Brian O'Connor. London: Blackwell, 2000 .

-..-- Aesthetic Theory. Edited by Gretel Adorno and Rolf Tiedeman. Translated, edited, and with a translator's introduction by Robert Hullot-Kentor. Minneapolis: University of Minnesota Press, 1997.

-..--. Critical Models: Interventions and Catchwords. Translated and with a preface by Henry $w$. Pickford. New York: Columbia University Press, 1998).

----. The Jargon of Authenticity. Translated by Knut Tarnowski and Frederic Will. London: Routledge Classics, 2003.

-.--. Minima Moralia: Reflections from Damaged Life. Translated by E.F.N. Jephcott. London: Verso, 1974 .

-----. Negative Dialectics. Translated by E.B. Ashton. New York: Continuum, 1995.

-.-.-. Notes to Literature. Vol. 2. Translated by Shierry Weber Nicholson. New York: Columbia University Press, 1992.

Agamben, Giorgio. The Coming Community. Translated by Michael Hardt. Minneapolis: University of Minnesota Press, 1993.

-.---. Homo Sacer: Sovereign Power and Bare Life. Translated by Daniel Heller-Roazen. Stanford: Stanford University Press, 1998.

-.--. Idea of Prose. Translated by Michael Sullivan and Sam Whitsutt. Albany: SUNY Press, 1995.

-.---. Infancy and History: On the Destruction of Experience. Translated by Liz Heron. London: Verso, 2007.

-----. Language and Death. Translated by Karen E. Pinkus with Michael Hardt. Minneapolis: University of Minnesota Press, 1991.

-----. The Man Without Content. Translated by Georgia Albert. Stanford: Stanford University Press, 1999.

- Means Without End: Notes on Politics. Translated by Vincenzo Binetti and Cesare Casarino. Minneapolis: University of Minnesota Press, 2000. 
-...-. The Open: Man and Animal. Translated by Jeff Fort. Stanford: Stanford University Press, 2004.

-----. Potentialities. Translated by Daniel Heller-Roazen. Stanfard: Stanford University Press, 1999.

----. Profanations. Translated by Kevin Attell. New York: Zone Books, 2007.

------ Remnants of Auschwitz: The Witness and the Archive. Translated by Daniel Heller-Roazen. New York: Zone Books, 2002.

-----. Stanzas: Word and Phantasm in Western Culture. Translated by Ronald L. Martinez. Minneapolis: University of Minnesota Press, 1993.

-.-.-. State of Exception. Translated by Kevin Attell. Chicago: University of Chicago Press, 2003.

-----. The Time That Remains: A Commentary on the Letter to the Romans. Translated by Patricia Dailey. Stanford: Stanford University Press, 2005.

Ainley, Alison. "Luce Irigaray: Divine Spirit and Feminine Space." In Post-Secular Philosophy: Between Philosophy and Theology. Edited by Philip Blong. London: Routledge, 1998.

Alsop, Rachel, Annette Fitzsimmons, Kathleen Lennon and Rosalind Minsky. Theorizing Gender. Cambridge: Polity Press, 2002.

Anonymous. "The Art of Grippage." http://everything2.com/user/fugdup/writeups/Grip. Accessed June 1, 2010 .

Badiou, Alain. Saint Paul: The Foundation of Universalism. Translated by Ray Brassier. Stanford: Stanford University Press, 2003.

Bakhtin, Mikhail. The Dialogic Imagination: Four Essays. Edited by Michael Holquist. Translated by Caryl Emerson and Michael Holquist. Austin: University of Texas Press, 1981.

Barth, Karl. The Epistle to the Romans. Translated by Edwin C. Hoskyns. Oxford: Oxford University Press, 1968.

Bechky, Beth A. "Gaffers, Gofers, and Grips: Role-Based Coordination in Temporary Organizations." Organization Science. 17:1 (JanuaryFebruary, 2006) 3-21.

Benhabib, Seyla. Critique, Norm and Utopia: A Study of the foundations of Critical Theory. New York: Columbia University Press, 1986.

Benjamin, Walter. Illumintions: Essays and Reflections. Edited and with an introduction by Hannah Arendt. Translated by Harry Zohn. New York: Schocken Books, 1968.

-.---. The Origin of German Tragic Drama. Translated by John Osborne. London: Verso, 1998. 
-... "The Work of Art in the Age of Mechanical Reproduction."

Marxists.org,

WWw.marxists.org/reference/subject/philosophy/works/ge/benjamin.htm. (accessed December 1, 2005).

Berg, Maggie. "Contradictions': Poststructuralism and Feminism." Signs 7:1 (Autumn, 1991) 50-70.

Berman, Russe11. "Adorno's Politics." In Adorno: A Critical Reader, edited by Nigel Gibson and Andrew Rubin. London: Blackwell, 2002.

Bernstein, J.M. Adorno: Disenchantment and Ethics. Cambridge: Cambridge University Press, 2001.

-----. "Bare Life, Bearing Witness: Auschwitz and the Pornography of Horror." Parallax 10 (Winter, 2004) 2-16.

Best, Steven and Douglas Kellner. Postmodern Theory: Critical Interrogations. New York: Guilford Press, 1991.

Bibliothèque Nationale Française. "Introduction." Utopie: La quète de la société idéale en occident. Online exhibit. http://gallica.bnf.fr/Utopie/T1.htm (accessed October 20, 2008 ).

Bloch, Ernst. The Principle of Hope. Vol. 3 Translated by Neville Plaice, Stephen Plaice, and Paul Knight. Cambridge, MA: MIT Press, 1996.

Blond, Philip, ed. Post-Secular Philosophy: Between Philosophy and Theology. London: Routledge, 1998.

Braidotti, Rosi. Nomadic Subjects. New York: Columbia University Press, 1994.

Brown, Gillian and George Yule. Discourse Analysis. Cambridge: Cambridge University Press, 1983.

Brown, Marcia. Stone Soup. New York: Simon and Schuster, 1947.

Buck-Morss, Susan. The Origins of Negative Dialectics: Theodor $W$. Adorno, Walter Benjamin, and the Erankfurt Institute. New York: The Free Press, 1977.

Burke, Carolyn, Naomi Schor, and Margaret Whitford, eds. Engaging with Irigaray: Feminist Philosophy and Modern European Thought. New York: Columbia University Press, 1994.

Butler, Judith. Gender Trouble: Feminism and the Subversion of Identity. New York: Routledge, 1999.

-----. A 'Bad Writer' Bites Back. New York Times. March 20, 1999.

Calarco, Matthew and Steven DeCaroli, eds. Giorgio Agamben: Sovereignty and Life. Stanford: Stanford University Press, 2007. 
Chanter, Tina. Ethics of Eros: Irigaray's Rewriting of the Philosophers. New York: Routledge, 1995.

Cheah, Pheng, Elizabeth Grosz, Judith Butler and Drucilla Cornell. "The Future of Sexual Difference: An Interview with Judith Butler and Drucilla Cornell." Diacritics 28, no. 1 (Spring, 1998): 19-42.

Chouliaraki, Lilie and Norman Fairclough. Discourse in Late Modernity: Rethinking Critical Discourse Analysis. Edingurgh: Edinburgh University Press, 1999.

Corless, Roger. The Vision of Buddhism: The Space Under the Tree. New York: Paragon House, 1990.

Cornell, Drucilla. Beyond Accommodation: Ethical Feminism, Deconstruction, and the Law. New York: Routledge, 1991.

-----. Transformations: Recollective Imagination and Sexual Difference. New York: Routledge, 1993.

Davis, J.C. Utopia and the Ideal Society: A Study of English Utopian Writing 1516-1700. Cambridge: Cambridge University Press, 1983.

Debord, Guy. "Comments on the Society of the Spectacle." Translated by NOTBORED! http://www. notbored.org/commentaires.html (accessed December 9, 2009).

----- The Society of the Spectacle. Translated by Donald NicholsonSmith. New York: Zone Books, 1995.

de Botton, Alain. The Architecture of Happiness. New York: Vintage International, 2008.

Delany, Samuel R. "The Rhetoric of Sex, the Discourse of Desire," in Heterotopia: Postmodern Utopia and the Body Politic. Edited by Tobin Siebers. Ann Arbor: University of Michigan Press, 1994.

Derrida, Jacques. Speech and Phenomena and Other Essays on Husserl's Theory of Signs. Translated by David B. Allison. Evanston, IL: Northwestern University Press, 1973.

-----. Writing and Difference. Translated by Alan Bass. Chicago: University of Chicago Press, 1978.

Deuber-Mankowsky, Astrid. "Homo Sacer, das blosse Leben und das Lager Anmerkungen zu einem erneuten Versuch einer Kritik der Gewalt." Die Philosophin No. 25 (2002) 95-114.

Deutscher, Penelope. "The Inversion of Exceptionality: Foucault, Agamben, and 'Reproductive Rights.'" South Atlantic Quarterly 107:1 (Winter, 2008) 55-70.

--.--. A Politics of Impossible Difference: The Later Work of Luce Irigaray. Ithaca, NY: Cornell University Press, 2002. 
Deutscher, Penelope, Mary Beth Mader and Alison Stone. "Critical Exchange." differences: a journal of feminist cultural studies 19:3 (Fall, 2008) 126-157.

de Vries, Hent. Minimal Theologies: Critiques of Secular Reason in Adorno and Levinas. Translated by Geoffrey Hale. Baltimore: The Johns Hopkins University Press, 2005.

Donnelly, Dorothy F. Patterns of Order and Utopia. New York: St. Martin's Press, 1998.

Durantaye, Leland de la. Giorgio Agamben: A Critical Introduction. Stanford: Stanford University Press, 2009.

Ebert, Teresa L. "Review: The Crisis of Representation in Cultural Studies: Reading Postmodern Texts." American Quarterly 38 (Winter, 1986) : 894-902.

Elkins, James. On the Strange Place of Religion in contemporary Art. London: Routledge, 2004.

Finlayson, James Gordon. "Adorno on the Ethical and The Ineffable." http://www.sussex.ac.uk/Users/jgf21/research/AEI.rtf (accessed March 1, 2010).

-.-.-. "Bare Life' and Politics in Agamben's Reading of Aristotle." The Review of Politics 72 (2010) 97-126.

----. "The Work of Art and the Promise of Happiness." World Picture 3: Happiness. Proceedings of the 2009 World Picture Conference, October 23-24, 2009, Oklahoma State University. http://www.okstate.edu/worldpicture/. (accessed March 22, 2010).

Foucault, Michel. Le courage de la vérité: Le gouvernement de soi et des autres II: Cours au Collège de France (1983-1984). Edited by Eédéric Gros, A. Gallimard. Paris: Seuil, 2009.

----- Fearless Speech. Edited by Joseph Pearson. Los Angeles: Semiotext (e), 2001 .

-----. Introduction Vol. I of A History of Sexuality. Translated by Robert Hurley. New York: Vintage Books, 1990.

----. The Order of Things. London: Routledge, 1989.

Fraser, Nancy. "Michel Foucault: A 'Young Conservative'?" Ethics 96, no. 1 (1985): 165-184.

Freud, Sigmund. Civilization and its Discontents. Translated by James Strachey. New York: W.W. Norton, 1961.

Funk \& Wagnalls Standard College Dictionary. New York: Harcourt, Brace $\&$ World, Inc. , 1966.

Garrett, Susan R. No Ordinary Angel: Celestial Spirits and Christian Claims About Jesus. New Haven: Yale University Press, 2008. 
Garrow, David J. Protest at Selma: Martin Luther King, Jr. and the Voting Rights Act of 1965. New Haven: Yale University Press, 1978.

Gaunilo of Marmoutiers. "Pro Insipiente." in God, Mind and Freedom. Vol. III of First Philosophy: Fundamental Problems and Readings in Philosophy. Edited by Andrew Bailey. Orchard Park, NY: Broadview Press, 2004 .

Geoghegan, Vincent. Utopianism and Marxism. London: Methuen, 1987.

Gombrich, E.H. The Story of Art. London: Phaidon Press, 2006.

Griffiths, Douglas. Religious Reading: the Place of Reading in the Practice of Religion. Oxford: Oxford University Press, 1999.

Grosz, Elizabeth. Jacques Lacan: A feminist introduction. London: Routledge, 1990.

Gutting, Gary. French Philosophy in the Twentieth Century. Cambridge: Cambridge University Press, 2001.

Hame1, Jeffrey M. "Lighting vs. Illuminating." http://www. studentfilmmakers. com/news/printer 1610.shtml. Accessed June 1,2010 .

Harris, Leonard. "Postmodernism and Utopia, an Unholy Alliance." in Racism, the City, and the state. Edited by Malcolm Cross and Michael Keith. London: Routledge, 1993.

Hartley, George. The Abyss of Representation: Marxism and the Postmodern Sublime. Durham, NC: Duke University Press, 2003.

Haynes, Patrice. "To rescue means to love things': Adorno and the Reenchantment of Bodies." Critical Quarterly. 47:3 64-78.

Hegel, Georg Wilhelm Eriedrich. "The Philosophy of Fine Art." Translated by F.P.B. Osmaston. In Albert Hofstadter and Richard Kuhns, eds. Philosophies of Art and Beauty: Selected Readings in Aesthetics from Plato to Heidegger. Chicago: University of Chicago Press, 1976 .

Heidegger, Martin. Basic Writings. Edited by David Farrell Krell. London: HarperPerennial, 2008.

-----. On the Way to Language. Translated by Peter D. Hertz. New York: Harper and Row, Publishers, 1971.

-----.". . Poetically Man Dwells. . ." Translated by Albert Hofstadter. In Philosophical and Political Writings. Edited by Manfred Stassen. New York: Continuum, 2006.

Hofstadter, Albert and Richard Kuhns, eds. Philosophies of Art and Beauty: Selected Readings in Aesthetics From Plato to Heidegger. Chicago: University of Chicago Press, 1976.

Horkheimer, Max and Theodor W. Adorno. Dialectic of Enlightenment: Philosophical Fragments. Edited by Gunzelin Schmid Noerr. 
Translated by Edmund Jephcott. Stanford: Stanford University Press, 2002 .

Hullot-Kentor, Robert. Introduction to Aesthetic Theory by Theodor $W$. Adorno, translated by Robert Hullot-Kentor, edited by Gretel Adorno and Rolf Tiedeman. Minneapolis: University of Minnesota Press, 1997.

-...-. Foreword to Kierkegaard: Construction of the Aesthetic by Theodor W. Adorno, translated by Robert Hullot-Kentor. Minneapolis: University of Minnesota Press, 1989.

-----. "Right Listening and a New Type of Human Being," in The Cambridge Companion to Adorno. Edited by Tom Huhn. Cambridge: Cambridge University Press, 2004.

Huntingon, Patricia J. Ecstatic Subjects, Utopia, and Recognition: Kresteva, Heidegger, Irigaray. Albany, NY: SUNY Press, 1998.

Irigaray, Luce. An Ethics of Sexual Difference. Translated by Carolyn Burke and Gillian C. Gill. Ithaca, NY: Cornell University Press, 1993.

-----. I Love to You. Translated by Alison Martin. New York: Routledge, 1996.

-.-.-. L'oubli de I'air Chez Martin Heidegger. Paris: Editions de Minuit, 1983.

-----. Marine Lover of Friedrick Nietzsche. Translated by Gillian C. Gill. New York: Columbia University Press, 1991.

-.---. Sharing the World. New York: Continuum, 2008.

-.---. Teaching. Edited by Luce Irigaray with Mary Green. New York: Continuum, 2008.

-.---. This Sex Which is Not One. Translated by Catherine Porter with Carolyn Burke. Ithaca, NY: Cornell University Press, 1985.

-----. The Way of Love. Translated by Heidi Bostic and Stephen Pluhacek. London: Continuum, 2002.

Jacoby, Russell. Picture Imperfect: Utopian Thought for an Anti-Utopian Age. New York: Columbia University Press, 2005.

Jager, Lorenz. Adorno: A Political Biography. Translated by Stewart Spencer. New Haven: Yale University Press, 2004.

Jay, Martin. Adorno. Cambridge, MA: Harvard University Press, 1984.

-.---. "Adorno in America." New German Critique no. 31 (Winter, 1984): $157-182$.

Jameson, Fredric. Archaeologies of the Future: The Desire Called Utopia and Other Science Fictions. London: Verso, 2005. 
----. Late Marxism: Adorno or the Persistence of the Dialectic. London: Verso, 1990.

-.---. The Political Unconscious: Narrative as a Socially Symbolic Act. Ithaca, NY: Cornell University Press, 1981.

Jones, Serene. "Divining Women: Irigaray and feminist Theologians." Yale French Studies 87 (1995): 42-67.

Joy, Morny, Kathleen $O^{\prime}$ Grady and Judith L. Poxon. French Feminists on Religion: A Reader. London: Routledge, 2002.

Kalyvas, Andreas. "The Sovereign Weaver: Beyond the Camp." In Andrew Norris, ed., Politics, Metaphysics, and Death: Essays on Giorgio Agamben's Homo Sacer. Durham: Duke University Press, 2005.

Kellner, Douglas. "Ernst Bloch, Utopia and Ideology Critique." Illuminations. http://www.uta.edu/huma/illuminations/kell1.htm. (accessed November 17, 2009)

Kent, Stephen A. 'Weber, Goethe, and the Nietzschean Allusion: Capturing the Source of the 'Iron Cage' Metaphor." Sociological Analysis 44, no. 4 (Winter, 1983): 297-319.

Krell, David Farell. "Two Apothecaries: Novalis and Derrida." Studies in Romanticism 46, no. 3 (Summer, 2007): 289-309.

Kumar, Krishan. Utopianism. Minneapolis: University of Minneapolis Press, 1991.

Lacan, Jacques. My Teaching. Translated by David Macey. London: Verso, 2008 .

LaCapra, Dominick. "Approaching Limit Events: Siting Agamben." In giorgio Agamben: Sovereignty and Life. Edited by Matthew Calarco and Steven DeCaroli. Stanford: Stanford University Press, 2007.

Leader, Darian and Judy Groves. Introducing Lacan. Cambridge: Icon Books, 2001.

Lee, Lisa Yun. Dialectics of the Body: Corporeality in the Philosophy of T.w. Adorno. New York: Routledge, 2005.

Leeb, Claudia. "Desires and Eears: Women, Class and Adorno." Theory and Event. 11:1 (February, 2008).

Leland, Dorothy. "Irigaray's Discourse on Feminine Desixe: Literalist and Strategic Readings." In Philosophy and Desire. Edited by Hugh J. Silverman. New York: Routledge, 2000.

LeGuin, Ursula K. The Wind's Twelve Quarters. New York: Harper \& Row, 1987.

Levi, Primo. The Drowned and the Saved. Translated by Raymond Rosenthal. New York: Summit Books, 1988. 
Levitas, Ruth. The Concept of Utopia. Syracuse: Syracuse University Press, 1990.

Lowell, Ross. Matters of Light and Depth. New York: Lowel-Light Manufacturing, Inc., 1992.

Löwy, Michael. Redemption and Utopia: Libertarian Judaism in Central Europe. Translated by Hope Heany. Stanford: Stanford University Press, 1992.

Ludtke, Martin and Ted R. Weeks. "The Utopian Motif is Suspended: Conversation with Leo Lowenthal." New German Critique No. 38 (Spring-Summer, 1986) 105-111.

Macdonell, Diane. Theories of Discourse: An Introduction. London: $B$. Blackwell, 1986.

Macey, David. The Penguin Dictionary of Critical Theory. London: Penguin Books, 2000.

Marcuse, Herbert. One-Dimensional Man: Studies in the Ideology of Advanced Industrial Society. Boston: Beacon Press, 1966.

Marin, Louis. Utopics: Spatial Play. Atlantic Highlands, NJ: Hunanities Press, Inc., 1984.

Martin, F. David and Lee A. Jacobus. The Humanities Through the Arts. $6^{\text {th }}$ ed. New York: McGraw-Hill, 2004.

Marx, Karl. The German Ideology Part One with Selections from Parts Two and Three and Supplementary Texts. Edited by C.J. Arthur. New York: International Publishers, 1974.

Masciandaro, Nicola. "Introduction." Glossator 1 (Fall, 2009) i-ii. http://ojs.gc.cuny.edu/index.php/glossator/article/viewFile/510/552 (accessed)

Mazower, Mark. "Foucault, Agamben: Theory and the Nazis." boundary 2 35:11 (Spring, 2008) 23-34.

Menke, Christopher. The Sovereignty of Art: Aesthetic Negativity in Adorno and Derrida. Translated by Neil Solomon. Cambridge, MA: MIT Press, 1998.

Miller, Nichole E. "The Sexual Politics of Pain: Hannah Arendt Meets Shakespeare's Shrew." Journal of Cultural and Religious Theory $7: 2$ (Spring, 2006) 18-32.

Mills, Catherine. The Philosophy of Agamben. Montreal: McGill-Queens University Press, 2008.

-.---. "Playing with Law: Agamben and Derrida on Post-Juridical Justice." South Atlantic Quarterly 107:1 (Winter, 2008) 15-36.

Mills, Patricia. Feminist Interpretations of Hegel. University Park, PA: Pennsylvania State University Press, 1996. 
Mills, Sara. Discourse. New York: Routledge, 2004.

More, Thomas. Utopia. Translated by Paul Turner. London: Penguin Classics, 1965.

Mumford, Lewis. The Story of Utopias. New York: Boni and Liveright, 1922 .

Nealon, Jeffrey T. "Thinking/Writing the Postmodern: Representation, End, Ground, Sending." boundary 220 (Spring, 1993) : 221-241.

Negri, Antonio. "The Discreet Taste of the Dialectic." In Giorgio Agamben: Sovereignty and Life. Edited by Matthew Calarco and Steven DeCaroli. Stanford: Stanford University Press, 2007.

-----. "The Ripe Fruit of Redemption." Translated by Arianna Bove. Generation Online. http://www.generationonline.org/t/negriagamben.htm (accessed May 24, 2010).

Nietzsche, Friedrich. "On Truth and Lying in an Extra-Moral Sense." In Friedrich Nietzsche on Rhetoric and Language, edited and translated by Sander L. Gilman, Carole Blair and David $J$. Parent. New York: Oxford University Press, 1989. 246-257.

Nye, Andrea. "The Hidden Host: Irigaray and Diotima at Plato's Symposium." Hypatia 33:3 (Winter, 1989) 45-61.

Gibson, Nigel. "Rethinking an Old Saw: Dialectical Negativity, Utopia, and Negative Dialectic in Adorno's Hegelian Marxism." In Adorno: A Critical Reader, edited by Nigel Gibson and Andrew Rubin. Oxford: Blackwell, 2002.

Norris, Andrew, ed. Politics, Metaphysics, and Death: Essays on Giorgio Agamben's Homo Sacer. Durham, NC: Duke University Press, 2005.

Nussbaum, Martha. The Therapy of Desire: Theory and Practice in Hellenistic Ethics. Pinceton: Princeton University Press, 1994.

O'Connor, Brian. Adorno's Negative Dialectic: Philosophy and the Possibility of Critical Rationality. Cambridge, MA: The MIT Press, 2004 .

Paden, Roger. "Foucault's Anti-Humanism." Human Studies 10, no. 1 (1987): 123-141.

Pelikan, Jaroslav Jan. The Growth of Medieval Theology (600-1300). Chicago: University of Chicago Press, 1978.

Pickford, Henry w. Preface to Critical Models: Interventions and Catchwords by Theodor $W$. Adorno. Translated by Henry W. Pickford. New York: Columbia University Press, 1998.

Rawes, Peg. Irigaray for Architects. Oxford: Routledge, 2007.

Robinson, Hilary. Reading Art, Reading Irigaray: The Politics of Art by Women. London: I.B. Tauris, 2006. 
Rose, Gillian. The Melancholy Science: An Introduction to the Thought of Theodor W. Adorno. New York: Macmillan, 1978.

Rosenau, Pauline Marie. Post-Modernism and the Social Sciences: Insights, Inroads and Intrusions. Princeton: Princeton University Press, 1992.

Rothberg, Michael. Traumatic Realism: The Demands of Holocaust Representation. Minneapolis: University of Minnesota Press, 2000.

Sarup, Madan. An Introductory Guide to Post-Structuralism and Postmodernism, $2^{\text {nd }}$ ed. Athens, GA: University of Georgia Press, 1993.

Salzani, Carlo. "Quodlibet: Giorgio Agamben's Anti-utopia." Paper presented to the $9^{\text {th }}$ International Conference of the Utopian Studies Society, July 3-5, 2008, University of Limerick.

Scharlemann, Robert P. "Totality: A Philosophical and Theological Problem Between Tillich and the Frankfurt School." Laval théologique et philosophique 47, no. 3 (1991) 329-341. http://id.erudit.org/iderudit/400626er (accessed January 11, 2010 ).

Smith, Barbara Herrnstein. "On the Margins of Discourse." Critical Inquiry 1 , no. 4 (1975): 769-798.

South Atlantic Quarterly. (Winter, 2008)

Stone, Alison. "The Sex of Nature: A Reinterpretation of Irigaray's Metaphysics and Political Thought." Hypatia 18, no. 3 (Autumn, 2003): $60-84$.

Strugatsky, Arkady and Boris Strugatsky. Roadside Picnic. Translated by Antonina W. Bouis. Cryptomaoist Editions, http://www.cca.org/cm/ (accessed).

Taubes, Jacob. The Political Theology of Paul. Translated by Dana Hollander. Stanford: Stanford University Press, 2004.

Thomas, Francis-Noël and Mark Turner. Clear and Simple as the Truth. Princeton: Princeton University Press, 1994.

Tillich, Paul. Political Expectation. New York: Harper and Row, 1971.

Tolstoy, Leo. How Much Land Does a Man Need? and Other Stories. Translated by Ronald Wilks. London: Penguin, 1993.

Turner, Bryan S. Introduction to Baroque Reason: The Aesthetics of Modernity by Christine Buci-Glucksmann, translated by Patrick Camiller. London: Sage Publications, 1994.

Vahanian, Noëlle. Language, Desire, and Theology. London: routledge, 2003.

Wall, Thomas Carl. Radical Passivity: Levinas, Blanchot, and Agamben. Albany, NY: SUNY Press, 1999. 
Walter, Simon Patrick. "Situating Irigaray." in Philosophy and Desire. Edited by Hugh J. Silverman. London: Routledge, 2000.

Ward, Steven. "The Revenge of the Humanities: Reality, Rhetoric, and the Politics of Postmodernism." Sociological Perspectives 38 (Summer, 1995): 109-128.

Watkin, William. The Literary Agamben: Adventures in Logopoiesis. New York: Continuum, 2010.

Weber, Max. From Max Weber: Essays in Sociology. Translated, edited and with an introduction by H.H. Gerth and C. Wright Mills. New York: Oxford University Press, 1946.

-----. The Protestant Ethic and the Spirit of Capitalism. Translated by Talcott Parsons. New York: Charles Scribner's Sons, 1958.

Whitford, Margaret. "Irigaray, Utopia and the Death Drive." In Engaging With Irigaray: Feminist. Philosophy and Modern European Thought, edited by Carolyn Burke, Naomi Schor, and Margaret Whitford. New York: Columbia University Press, 1994.

---.- Luce Irigaray: Philosophy in the Feminine. London: Routledge, 1991 .

Wilde, Oscar. The Soul of Man Under Socialism and Selected Critical Prose. London: Penguin Classics, 2001.

Wilson, Dan. "Closing Time," in Semisonic Feeling Strangely Fine. MCA UK ASIN B0000062XN.

Wolin, Richard. "Utopia, Mimesis, and Reconciliation: A Redemptive Critique of Adorno's Aesthetic Theory." Representations 32 (Autumn, 1990) 33-49.

Ziarek, Ewa Plonowska. An Ethics of Dissensus: Postmodernity, Feminism, and the Politics of Radical Democracy. Stanford: Stanford University Press, 2001.

-----. "Feminine 'I can': On Possibility and Praxis in Agamben's Work." Theory and Event 13:1 (2010) Project MUSE, University of Louisville Library, Louisville, KY, http://muse.jhu.echo.louisville.edu/ (accessed March 28, 2010)

Ziarek, Krzystof. "Proximities: Irigaray and Heidegger on Difference." Continental Philosophy Review 33:2 (April, 2000) 133-158.

Žižek, Slavoj. In Defense of Lost Causes. London: Verso, 2008.

Zuidervaart, Lambert. Social Philosophy After Adorno. Cambridge: Cambridge University Press, 2007.

-----. "Theodor W. Adorno." Stanford Encyclopedia of Philosophy. http://plato.stanford.edu/entries/adorno, (accessed August 3, 2007) 
CURRICULUM VITAE

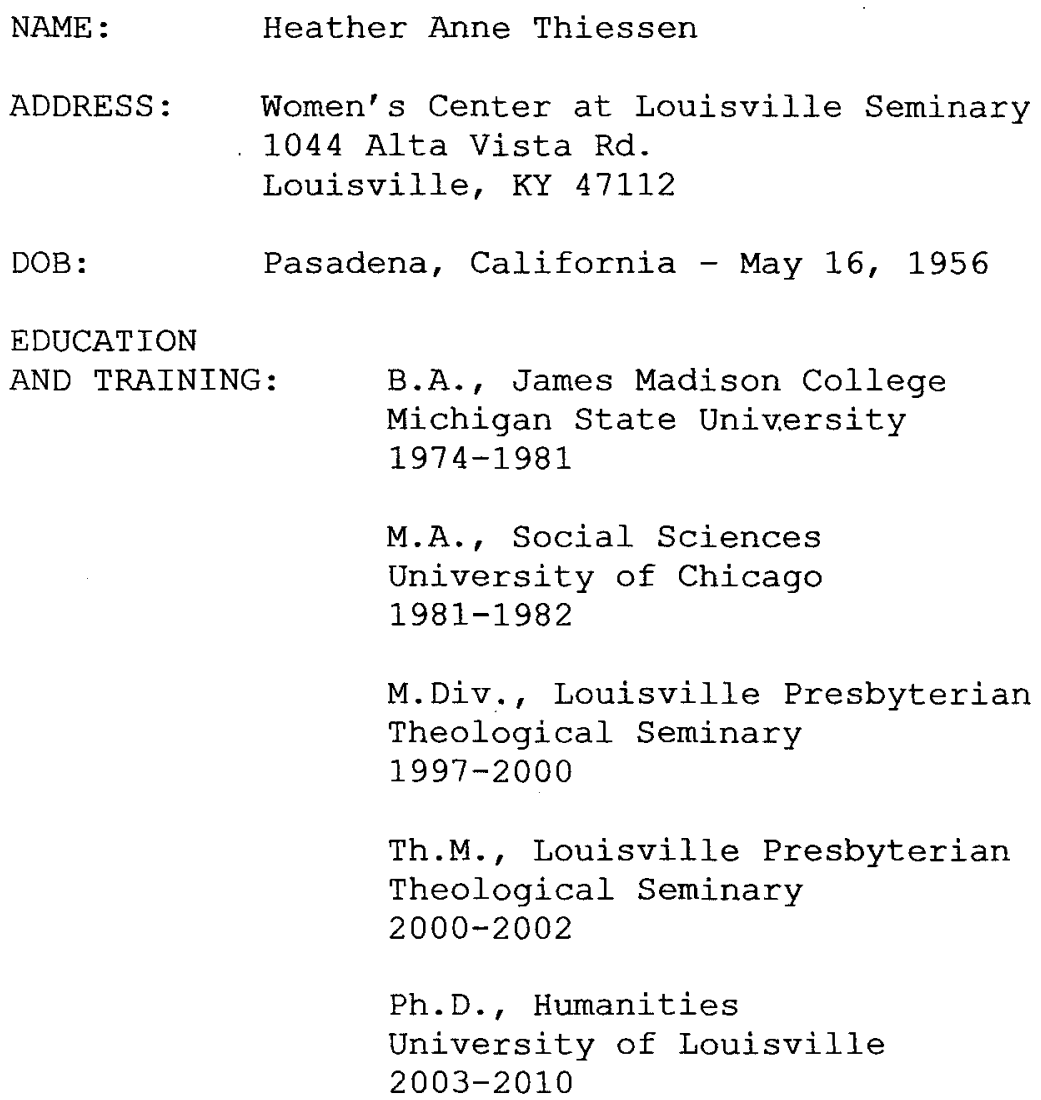

AWARDS: E.L. Bell Memorial Prize 1998

Bernice Bean and Gladys Kendall Prize 2000

Fielding Lewis Walker Fellowship 2000

NATIONAL MEETING PRESENTATIONS :

"Something Whatever in Common: Prospects for Queer Community." Presented to the Queer Theory Consultation of the American Academy of Religion, Washington, DC, November 17-21, 2006. 